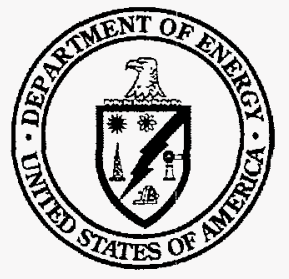

U.S. Department of Energy

DOE/ID/12584-263

Grand Junction Projects Office

GJPO-ES-17

P.O. Box 2567

Grand Junction, CO 81502-2567

\title{
Site Environmental Report for Calendar Year 1995
}

\section{May 1996}

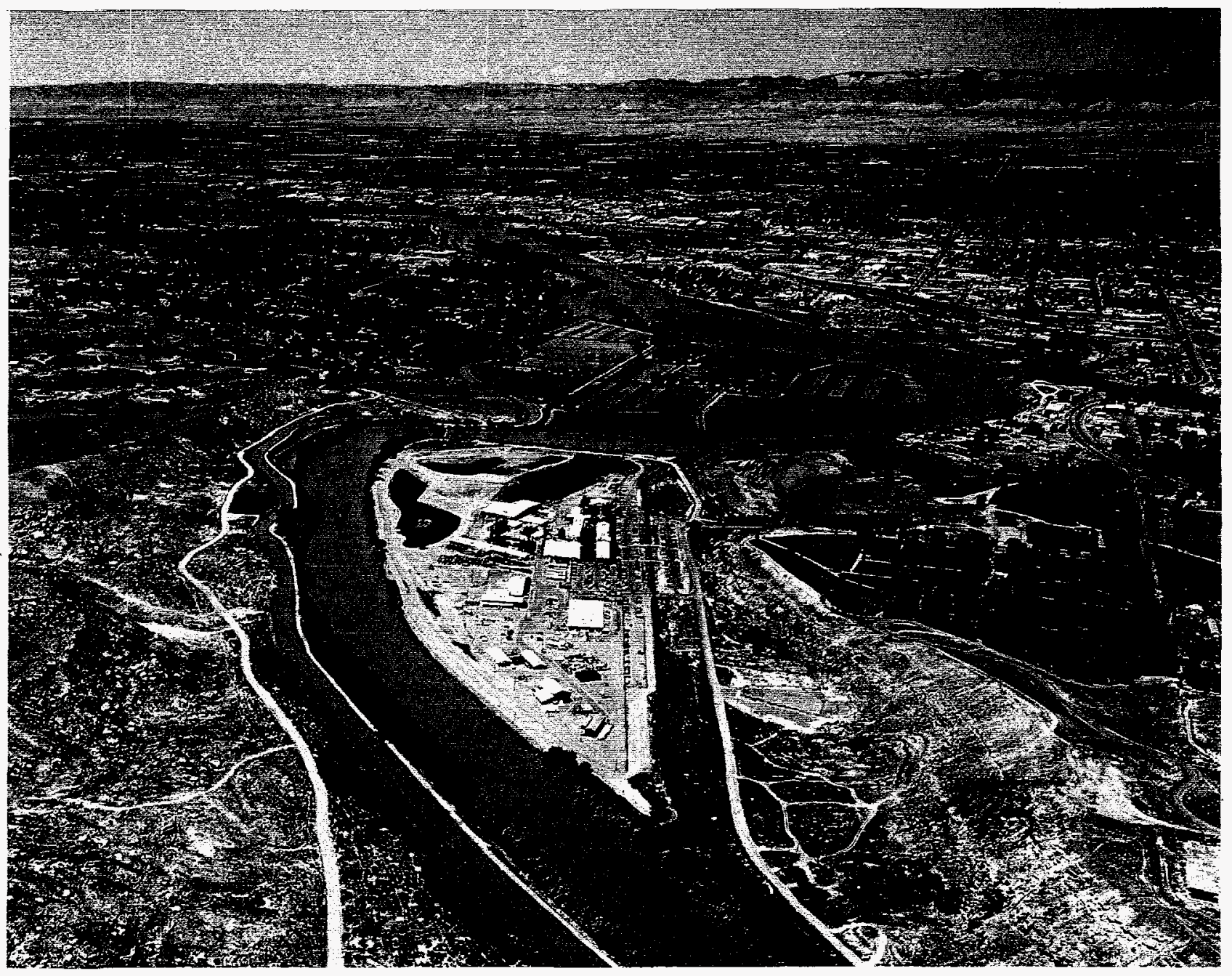

Work Performed Under DOE Contract No. DE-AC04-94AL96907 for the U.S. Department of Energy

Approved for public release; distribution is unlimited. 


\section{DISCLAIMER}

Portions of this document may be illegible in electronic image products. Images are produced from the best available original document. 


\section{DISCLAIMER}

This report was prepared as an account of work sponsored by an agency of the United States Government. Neither the United States Government nor any agency thereof, nor any of their employees, makes any warranty, express or implied, or assumes any legal liability or responsibility for the accuracy, completeness, or usefulness of any information, apparatus, product, or process disclosed, or represents that its use would not infringe privately owned rights. Reference herein to any specific commercial product, process, or service by trade name, trademark, manufacturer, or otherwise does not necessarily constitute or imply its endorsement, recommendation, or favoring by the United States Government or any agency thereof. The views and opinions of authors expressed herein do not necessarily state or reflect those of the United States Government or any agency thereof. 
DOE/ID/12584-263

GJPO-ES-17

\title{
U.S. Department of Energy \\ Grand Junction Projects Office Site Environmental Report for Calendar Year 1995
}

\author{
May 1996 \\ Prepared for \\ U.S. Department of Energy \\ Grand Junction Projects Office \\ Albuquerque Operations Office \\ P.O. Box 2567 \\ Grand Junction, CO 81502-2567 \\ Prepared by \\ Rust Geotech \\ P.O. Box 14000 \\ Grand Junction, CO 81502
}




\section{Contents}

Abbreviations and Acronyms $\ldots \ldots \ldots \ldots \ldots \ldots \ldots \ldots \ldots \ldots \ldots$ Page

Executive Summary $\ldots \ldots \ldots \ldots \ldots \ldots \ldots \ldots \ldots \ldots \ldots \ldots \ldots \ldots \ldots \ldots \ldots$

1.0 Introduction $\ldots \ldots \ldots \ldots \ldots \ldots \ldots \ldots \ldots \ldots \ldots \ldots \ldots \ldots \ldots \ldots \ldots$

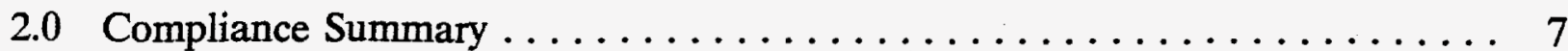

2.1 Compliance Status . . . . . . . . . . . . . . . . . 7

2.1.1 Comprehensive Environmental Response, Compensation, and

Liability Act . .................... 7

2.1.2 Superfund Amendments and Reauthorization Act, Title III . . . . 7

2.1.3 Resource Conservation and Recovery Act $\ldots \ldots \ldots \ldots \ldots \ldots 8$

2.1.4 National Environmental Policy Act .............. 9

2.1.5 Uranium Mill Tailings Radiation Control Act ........... 10

2.1.6 Clean Air Act/National Emission Standards for Hazardous

Air Pollutants . . . . . . . . . . . . . . . . . . 10

2.1.7 Clean Water Act/National Pretreatment Program .......... 10

2.1.8 Clean Water Act/Executive Order 11990, "Protection of

Wetlands" ............................. 11

2.1.9 Safe Drinking Water Act $\ldots \ldots \ldots \ldots \ldots \ldots \ldots \ldots \ldots \ldots \ldots$

2.1.10 Toxic Substances Control Act $\ldots \ldots \ldots \ldots \ldots \ldots \ldots \ldots \ldots$

2.1.11 Federal Insecticide, Fungicide, and Rodenticide Act . . . . . . . 12

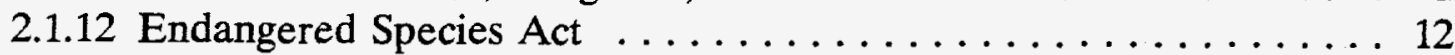

2.1.13 National Historic Preservation Act . . . . . . . . . . . . 13

2.1.14 Executive Order 11988, "Floodplain Management" . . . . . . . . . 13

2.2 Current Issues and Actions . . . . . . . . . . . . . . . . 13

2.2.1 Waste Minimization and Pollution Prevention ........... 13

2.2.2 Waste Management . . . . . . . . . . . . . . . 14

2.2.3 Mixed-Waste Treatment Program $\ldots \ldots \ldots \ldots \ldots \ldots \ldots \ldots$

2.2 .4 Environmental Audits . . . . . . . . . . . . . . . . . . . 17

2.2.5 Management Compliance Assessments . . . . . . . . . . . . . . 17

2.2.6 Environmental Compliance Tracking Systems . . . . . . . . . 18

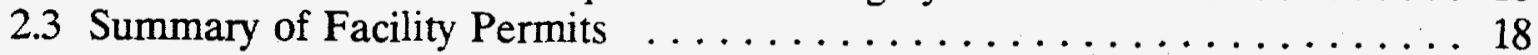

3.0 Environmental Program Information $\ldots \ldots \ldots \ldots \ldots \ldots \ldots \ldots \ldots \ldots \ldots \ldots$

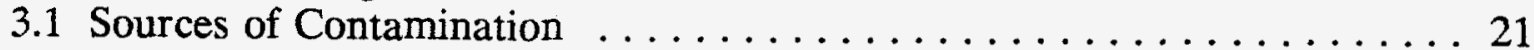

3.2 Environmental Monitoring Summary $\ldots \ldots \ldots \ldots \ldots \ldots \ldots \ldots \ldots \ldots$

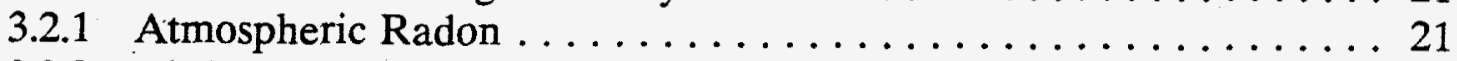

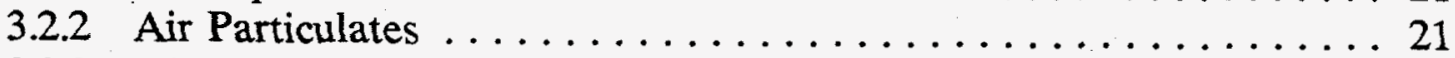

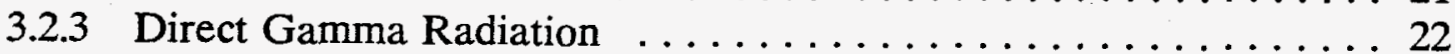

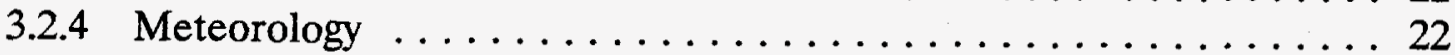




\section{Contents (continued)}

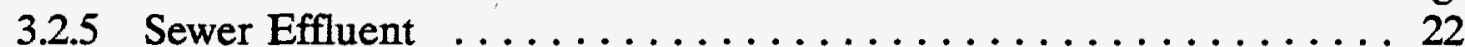

3.2 .6 Storm Water . . . . . . . . . . . . . . . . . 25

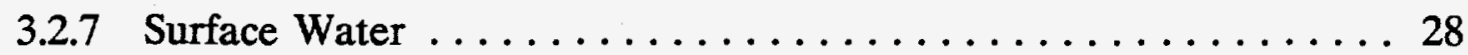

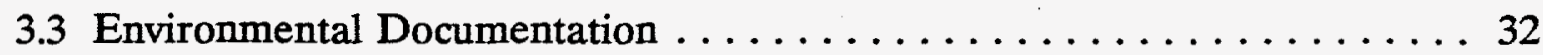

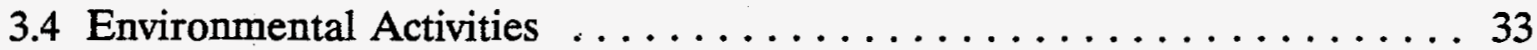

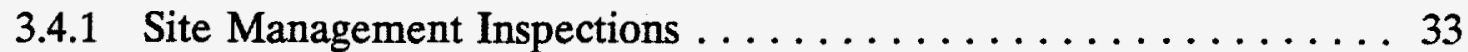

3.4 .2 Environmental Training $\ldots \ldots \ldots \ldots \ldots \ldots \ldots \ldots \ldots \ldots \ldots \ldots \ldots$

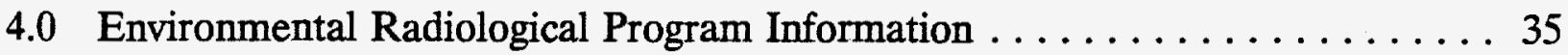

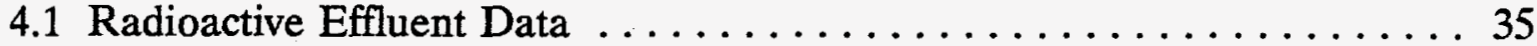

4.1.1 Liquid Sewage ....................... 35

4.1.2 Air Particulate Emissions . . . . . . . . . . . . . . 35

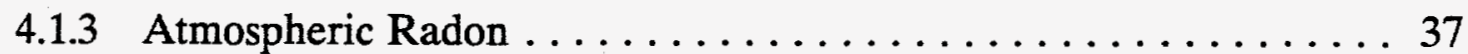

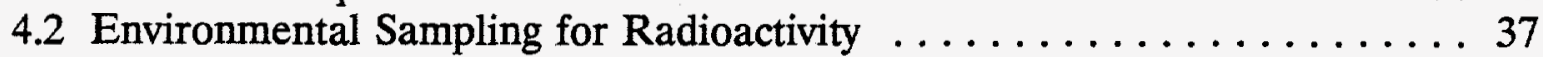

4.3 Off-Site Dose Modeling $\ldots \ldots \ldots \ldots \ldots \ldots \ldots \ldots \ldots \ldots \ldots \ldots \ldots$

5.0 Environmental Nonradiological Program Information . . . . . . . . . 39

5.1 Nonradiological Effluent Data . . . . . . . . . . . . . . . . 39

5.2 Environmental Sampling for Nonradiological Pollution . . . . . . . 39

6.0 Groundwater Monitoring and Protection Program $\ldots \ldots \ldots \ldots \ldots \ldots \ldots 4$

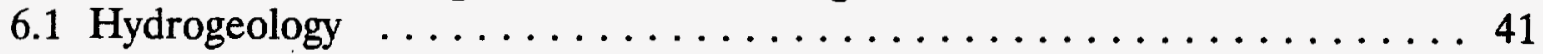

6.2 Groundwater Monitoring Program $\ldots \ldots \ldots \ldots \ldots \ldots \ldots \ldots \ldots$

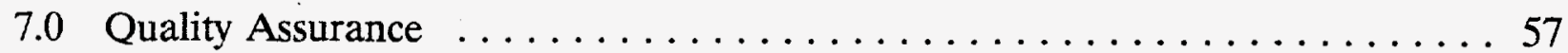

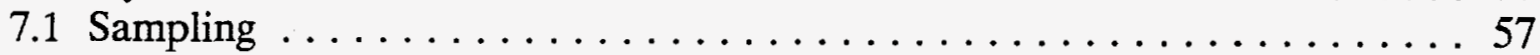

7.2 Laboratory Analysis . . . . . . . . . . . . . . . 57

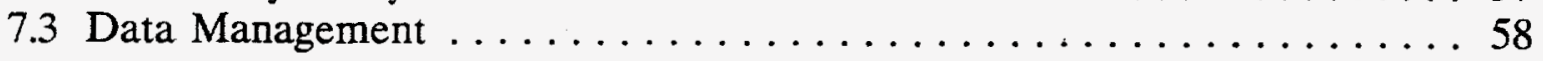

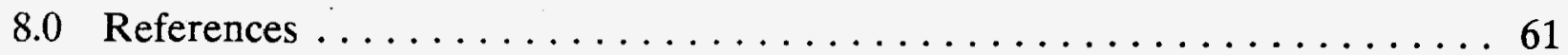

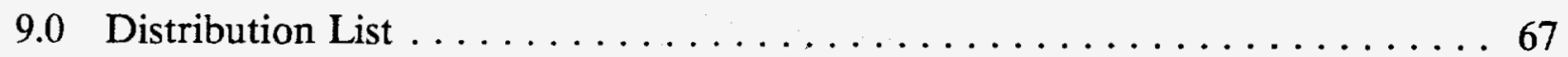

Appendix A. Monitoring Data $\ldots \ldots \ldots \ldots \ldots \ldots \ldots \ldots \ldots \ldots \ldots \ldots \ldots \ldots \ldots \ldots$

Appendix B. Time-Concentration Graphs $\ldots \ldots \ldots \ldots \ldots \ldots \ldots \ldots \ldots$ B-1

Appendix C. Well Location Maps Showing Groundwater Analytes

Exceeding Federal or State Standards . . . . . . . . . . . C-1 


\section{Figures}

Figure 1. DOE Grand Junction Projects Office Facility Location Map ...... 2

2. Formerly Contaminated Areas of the GJPO Facility Remediated as of June $1994 \ldots \ldots \ldots \ldots \ldots \ldots \ldots \ldots \ldots \ldots$. . . . . . . . . 4

3. Baghouse Sampling and Meteorological Monitoring Station Locations at the GJPO Facility . . . . . . . . . . . . . 23

4. GJPO Wind Speed and Direction ................ 24

5. Sewer-Effluent and Storm-Water Sampling Locations at the

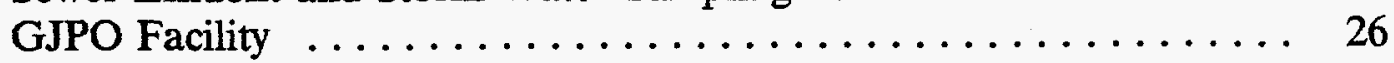

6. Surface-Water Sampling Locations At and Near the GJPO Facility . . 29

7. Typical Geological Cross Section of Alluvial Aquifer at the

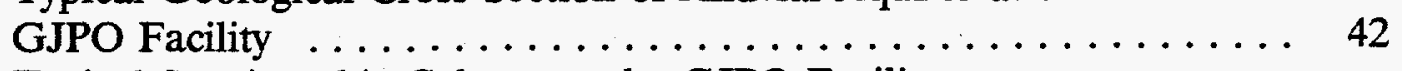

8. Typical Stratigraphic Column at the GJPO Facility (compiled from well GJ87-18) ................ 44

9. Groundwater Sampling Locations at the GJPO Facility . . . . . . . . 49

10. Maximum Concentrations of Groundwater Analytes Exceeding Federal or State Standards in Alluvial Well Samples at the GJPO Facility . . . . . . . . . . . 51

11. Uranium Concentrations in Groundwater at the GJPO Facility in June $1984 \ldots \ldots \ldots \ldots \ldots \ldots \ldots \ldots \ldots \ldots \ldots \ldots \ldots$

12. Uranium Concentrations in Groundwater at the GJPO Facility in

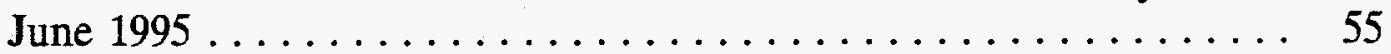

B-1a. Sulfate Concentrations at Upper Gunnison River Sampling Location . . . . . . . . . . . . . . . . . . . . B-3

B-1b. Sulfate Concentrations at Upper Middle Gunnison River Sampling Location . . . . . . . . . . . . . . . . B-4

B-1c. Sulfate Concentrations at Middle Gunnison River Sampling Location . . . . . . . . . . . . . . . . B-5

B-1d. Sulfate Concentrations at Lower Gunnison River Sampling Location . . . . . . . . . . . . . . . . . . . . . B-6

B-2a. Uranium Concentrations at Upper Gunnison River Sampling Location . . . . . . . . . . . . . . . . . . . . B-7

B-2b. Uranium Concentrations at Upper Middle Gunnison River Sampling Location . . . . . . . . . . . . . . . . B B-8

B-2c. Uranium Concentrations at Middle Gunnison River Sampling Location . . . . . . . . . . . . . . . . . . . . . . B-9

B-2d. Uranium Concentrations at Lower Gunnison River Sampling Location . . . . . . . . . . . . . . . . . . . B-10

B-3. Uranium Concentrations at North Pond Location . . . . . . . . B-11

B-4a. Uranium-234 + 238 Concentrations in Downgradient Well GJ84-04 . . . . . . . . . . . . . . . . . . . B-12

B-4b. Uranium-234, -238 Concentrations in Upgradient Well GJ84-10 . . B-13 B-5a. Molybdenum Concentrations in On-Site Well 10-19N . . . . . . . B-14 


\section{Figures (continued)}

Figure B-5b. Molybdenum Concentrations in Upgradient Well GJ84-10 . . . . B-15

B-6a. Arsenic Concentrations in On-Site Well 14-6NA . . . . . . . . B-16

B-6b. Arsenic Concentrations in Upgradient Well GJ84-10 . . . . . . . B-17

B-7a. Selenium Concentrations in On-Site Well GJ87-15 . . . . . . . . B-18

B-7b. Selenium Concentrations in Upgradient Well GJ84-10 . . . . . . . B-19

B-8a. Radium-226, -228 Concentrations in On-Site Well 8-4S . . . . . B B-20

B-8b. Radium-226, -228 Concentrations in Upgradient Well GJ84-10 . . B B-21

C-1. Concentrations of Groundwater Analytes Exceeding Federal or State Standards in Alluvial-Aquifer Well Samples in January 1995

C-2. Concentrations of Groundwater Analytes Exceeding Federal or State Standards in Alluvial-Aquifer Well Samples in April $1995 \ldots \ldots \ldots \ldots \ldots \ldots \ldots$. . . . . . . . . . . . . . . . .

C-3. Concentrations of Groundwater Analytes Exceeding Federal or State Standards in Alluvial-Aquifer Well Samples in June $1995 \ldots \ldots \ldots$. . . . . . . . . . . . . . . . . . . . . . . . C-5

C-4. Concentrations of Groundwater Analytes Exceeding Federal or State Standards in Alluvial-Aquifer Well Samples in July $1995 \ldots \ldots \ldots \ldots \ldots \ldots$. . . . . . . . . . . . . . . C-6

C-5. Concentrations of Groundwater Analytes Exceeding Federal or State Standards in Alluvial-Aquifer Well Samples in October 1995

\section{Tables}

Table 1. GJPO Facility Permits Active During 1995 . . . . . . . . . . . . . . . 19

2. Comparison of Sewer-Effluent Threshold Limits to 1995 Maximum Concentrations ...................... 25

3. Results of 1995 Storm-Water Effluent Monitoring . . . . . . . . . . . 27

4. Comparison of State of Colorado Surface-Water Quality Standards With 1995 and Historical Maximum Concentrations in Gunnison River . . . . . . . . . . . . . . . . . . . . . 30

5. Release Rates of Airborne Radioparticulates From the GJPO Facility During 1995

6. Effective Dose Equivalents Attributable to Radiological Emissions From the GJPO Facility During 1995

7. Comparison of Federal and State of Colorado Groundwater Quality Standards With 1995 and Historical Maximum Concentrations in the Alluvial Aquifer

8. 1995 GJPO Groundwater Sampling and Analytical

Design Schedule . . . . . . . . . . . . . . . . . . . 


\section{Tables (continued)}

Table 9. Summary of Analytical Results for Interlaboratory Quality

Assurance Programs . . . . . . . . . . . . . . . . 60

A-1. Sewer-Effluent Chemistry Data for GJPO Facility During 1995 . . . . A A-3

A-2. Surface-Water Chemistry Data Collected At and Near GJPO During 1995 . . . . . . . . . . . . . . . . . . . . . . . . A-7

A-3. Groundwater Chemistry Data Collected by Rust At and Near GJPO During 1995

A-4. QA/QC Chemistry Data Collected by Rust At and Near the GJPO During 1995 . . . . . . . . . . . . . . . . . . . A-15

A-5. Groundwater Chemistry Data Collected by Oak Ridge National Laboratory At and Near the GJPO During 1995

A-6. QA/QC Chemistry Data Collected by Oak Ridge National Laboratory At and Near the GJPO During 1995

A-7. Organic Constituents Detected in Samples Collected by Oak Ridge National Laboratory from Groundwater At and Near the GJPO During 1995

A-8. Target Compound List of Organic Constituents Included in Analysis of Groundwater Samples 


\section{Abbreviations and Acronyms}

$\begin{array}{ll}\text { BAT } & \text { best available technology } \\ \text { BOD } & \text { biological oxygen demand } \\ \text { CCR } & \text { Colorado Code of Regulations } \\ \text { CDPHE } & \text { Colorado Department of Public Health and Environment } \\ \text { CERCLA } & \text { Comprehensive Environmental Response, Compensation, and } \\ & \text { Liability Act } \\ \text { CESQG } & \text { conditionally exempt small quantity generator } \\ \text { Ci/yr } & \text { curies per year } \\ \text { CFR } & \text { U.S. Code of Federal Regulations } \\ \text { COE } & \text { U.S. Army Corps of Engineers } \\ \text { DOE } & \text { U.S. Department of Energy } \\ \text { AL } & \text { Albuquerque Operations Office } \\ \text { HQ } & \text { Headquarters } \\ \text { EA } & \text { environmental assessment } \\ \text { EDE } & \text { effective dose equivalent } \\ \text { EPA } & \text { U.S. Environmental Protection Agency } \\ \text { ESAT } & \text { Environmental Standards and Assessment Tracking } \\ \text { ETS } & \text { Environmental Tracking System } \\ \text { FIFRA } & \text { Federal Insecticide, Fungicide, and Rodenticide Act } \\ \text { FFCAct } & \text { Federal Facility Compliance Act } \\ \text { GJPO } & \text { Grand Junction Projects Office } \\ \text { GJPORAP } & \text { Grand Junction Projects Office Remedial Action Project } \\ \text { LDR } & \text { land disposal restriction } \\ \text { LTTCO } & \text { Lockheed Idaho Technology Company } \\ \text { LLW } & \text { low-level radioactive waste } \\ \mu \text { g/L } & \text { micrograms per liter } \\ \mu \text { mhos/cm } & \text { micromhos per centimeter } \\ \text { mrem } & \text { millirem } \\ \text { NEPA } & \text { National Environmental Policy Act of 1969 } \\ \text { NESHAP } & \text { National Emission Standards for Hazardous Air Pollutants } \\ \text { NPDES } & \text { National Pollutant Discharge Elimination System } \\ \text { NTS } & \text { Nevada Test Site } \\ \text { ORO } & \text { Oak Ridge Operations Office } \\ \text { ORNL } & \text { Oak Ridge National Laboratory } \\ \text { PCB } & \text { polychlorinated biphenyl } \\ \text { pCi } & \text { picocurie } \\ \text { ppm } & \text { parts per million } \\ \text { PPE } & \text { personal protective equipment } \\ \text { QA } & \text { quality assurance } \\ \text { QAPP } & \text { Quality Assurance Program Plan } \\ \text { QC } & \text { quality control } \\ \text { RCRA } & \text { Resource Conservation and Recovery Act } \\ & \end{array}$




\section{Abbreviations and Acronyms (continued)}

RI/FS

SARA

SQG

TCL

TDS

TOC

TSCA

TSS

UMTRA

UMTRCA

USFWS

$\mu \mathrm{g}$
Remedial Investigation/Feasibility Study

Superfund Amendments and Reauthorization Act

small quantity generator

Target Compound List

total dissolved solids

total organic carbon

Toxic Substances Control Act

total suspended solids

Uranium Mill Tailings Remedial Action

Uranium Mill Tailings Radiation Control Act

U.S. Fish and Wildlife Service

microgram 


\section{Executive Summary}

This report presents information pertaining to environmental activities conducted during calendar year 1995 at the U.S. Department of Energy (DOE) Grand Junction Projects Office (GJPO) facility in Grand Junction, Colorado. Rust Geotech, the operating contractor for the GJPO facility, prepared this report in accordance with the requirements of DOE Order 5400.1, General Environmental Protection Program, and supplemental guidance from DOE Headquarters.

Environmental activities conducted at the GJPO facility during 1995 were associated with mixed-waste treatment, site remediation, off-site dose modeling, and radiological and nonradiological monitoring.

In 1994, DOE-AL assigned DOE-GJPO Overall Program Manager responsibility for implementing the $A L$ Mixed-Waste Treatment Plan (DOE 1994). This plan establishes an approach for creating timely and cost-effective treatment capacity for facilities under DOE-AL oversight that store or generate mixed-wastes. DOE-GJPO also was assigned responsibility for designing and fabricating three mobile treatment unit technologies and for implementing a sort, survey, and decontamination project. These combined responsibilities and functions resulted in the creation of the GJPO Mixed-Waste Treatment Program.

As part of the GJPO Mixed-Waste Treatment Program, on-site treatability studies were conducted in 1995 that made use of pilot-scale evaporative-oxidation and thermaldesorption units and bench-scale stabilization. DOE-GJPO used some of its own mixedwaste as well as samples received from other DOE sites for these treatability studies. These studies are expected to conclude in 1996.

Removal of radiologically contaminated materials from GJPO facility buildings was conducted under the provisions of the Grand Junction Projects Office Remedial Action Project. Remediation activities included the removal of 394 metric tons of contaminated material from Buildings 18 and 28 and revegetation activities on the GJPO site; remediation was conducted in compliance with applicable permits.

Off-site dose modeling for the GJPO was conducted to determine compliance with current National Emission Standards for Hazardous Air Pollutants, Subpart H; DOE Order 5400.1, General Environmental Protection Program; and DOE Order 5400.5, Radiation Protection of the Public and the Environment. Modeling results indicated a total radioparticulate dose, or effective dose equivalent (EDE), to the maximally exposed off-site individual (400 meters west-northwest of the GJPO facility) of $5.19 \times 10^{-5}$ millirem per year $(\mathrm{mrem} / \mathrm{yr})$. This dose was calculated by summing the doses from all radioparticulate sources on the facility. The DOE and U.S. Environmental Protection Agency (EPA) standard for such emissions is $10 \mathrm{mrem} / \mathrm{yr}$. The collective population dose, including the radon source term, was 
calculated at 0.10 person-rem per year; no standard is associated with this dose. The total off-site EDE to the public from all sources of radiation emanating from the facility (i.e., radon and air particulates) was calculated at $9.11 \times 10^{-3} \mathrm{mrem} / \mathrm{yr}$, which is well below the DOE and EPA dose limit of $100 \mathrm{mrem} / \mathrm{yr}$ above background.

The radiological and nonradiological monitoring programs conducted at the GJPO facility included monitoring of meteorology, sewer effluent, storm water, surface water, and groundwater. On-site meteorological monitoring was conducted to support off-site dose modeling efforts.

Samples were drawn from the GJPO's sewer effluent to ensure compliance with the city of Grand Junction's Industrial Pretreatment Permit. All measured analyte concentrations were below threshold concentrations established by the permit.

Storm water was sampled at the GJPO facility in December 1995. Although the GJPO is not subject to EPA's permitting requirements for storm-water discharge, sampling was conducted as a best management practice. Data collected from annual events will be used to establish a water quality baseline for storm-water effluent and to assess the potential effects on water quality of the receiving pond. When compared to an EPA study of storm-water discharges, the 1995 GJPO storm-water discharge was similar in water quality to an average residential or commercial site.

Radiological and nonradiological constituents were monitored in surface waters on and near the GJPO facility. Surface-water sources sampled consisted of the North Pond, South Pond, and Wetland Area on the facility, and the Gunnison River adjacent to the facility. Analysis of samples collected from the ponds and Wetland Area indicated the presence of chloride, magnesium, manganese, sulfate, and uranium in higher-thanbackground concentrations. These analytes are associated with leachate from the uranium mill tailings formerly located on the facility. In samples from the Gunnison River, State water quality standards were not exceeded at any location during 1995.

Groundwater monitoring consisted of sampling the shallow alluvial aquifer underlying the GJPO facility. Analytical results indicated that arsenic, molybdenum, nitrate, selenium, total dissolved solids, gross alpha, and uranium concentrations exceeded standards established by the Uranium Mill Tailings Radiation Control Act and the Colorado Water Quality Control Commission in one or more wells during 1995. Groundwater modeling predicts that the groundwater will be cleaned to below applicable standards within 50 to 80 years after the uranium mill tailings sources are removed; data indicate passive remediation through the natural flushing action of the aquifer is progressing. 


\subsection{Introduction}

The U.S. Department of Energy (DOE) Grand Junction Projects Office (GJPO) facility is located in Mesa County, Colorado, immediately south and west of the Grand Junction city-limits (Figure 1). Lying on an inner bend of the Gunnison River, the facility occupies an elongated, north-south-trending tract of 25.0 hectares $(61.7$ acres) bounded on the west by the river and on the north, south, and east by city, county, and private property. An earthen dike is emplaced between the facility and the river. The Gunnison River, which converges with the Colorado River about 0.8 kilometer ( 0.5 mile) downstream of the facility, is used for seasonal recreation activities such as boating, fishing, and swimming.

Surrounding the facility on the north, south, and east are agricultural, open-range, and railroad lands. More densely populated areas of Grand Junction lie within 1 kilometer ( 0.6 mile) of the facility. The 1995 population of the city of Grand Junction and surrounding areas was approximately 105,000 .

In the immediate vicinity of the facility, the river canyon is 455 to 610 meters (1,500 to 2,000 feet) wide and 18 to 49 meters (60 to 160 feet) deep and is incised into the variegated siltstones, mudstones, and shales of the Brushy Basin Member of the Morrison Formation. Beneath the facility is a fine sandy soil, several inches to several feet thick, that is underlain by 6 to 12 meters (20 to 40 feet) of Quaternary alluvium composed of silty sands and sandy gravels. The groundwater within the alluvial aquifer has been contaminated by the leached products of on-site uranium mill tailings. Water from the aquifer is not used for any purpose. All domestic surface-water sources for the Grand Junction area are located upstream of the GJPO facility or are obtained from the Colorado River drainage system.

Personnel at the facility develop, support, and administer a variety of programs. Historically, personnel were primarily involved in uranium procurement, evaluation of domestic uranium resources, development of uranium extractive processes, and advancement of geologic and geophysical exploration techniques. The current mission of facility personnel is to provide project management, engineering, and scientific support to the Federal government's environmental restoration programs. Housed on the facility are fully equipped laboratories for analytical chemistry, mineralogy and petrology, radon, and electronics. Research groups at the facility have received funding for specific projects from various entities, including the U.S. Nuclear Regulatory Commission, U.S. Department of Defense, and DOE.

Uranium was milled, analyzed, and stored on the GJPO facility for a period of approximately 30 years, from the mid-1940s to the mid-1970s. All known contamination is believed to be the result of these past activities. According to historical records (those 


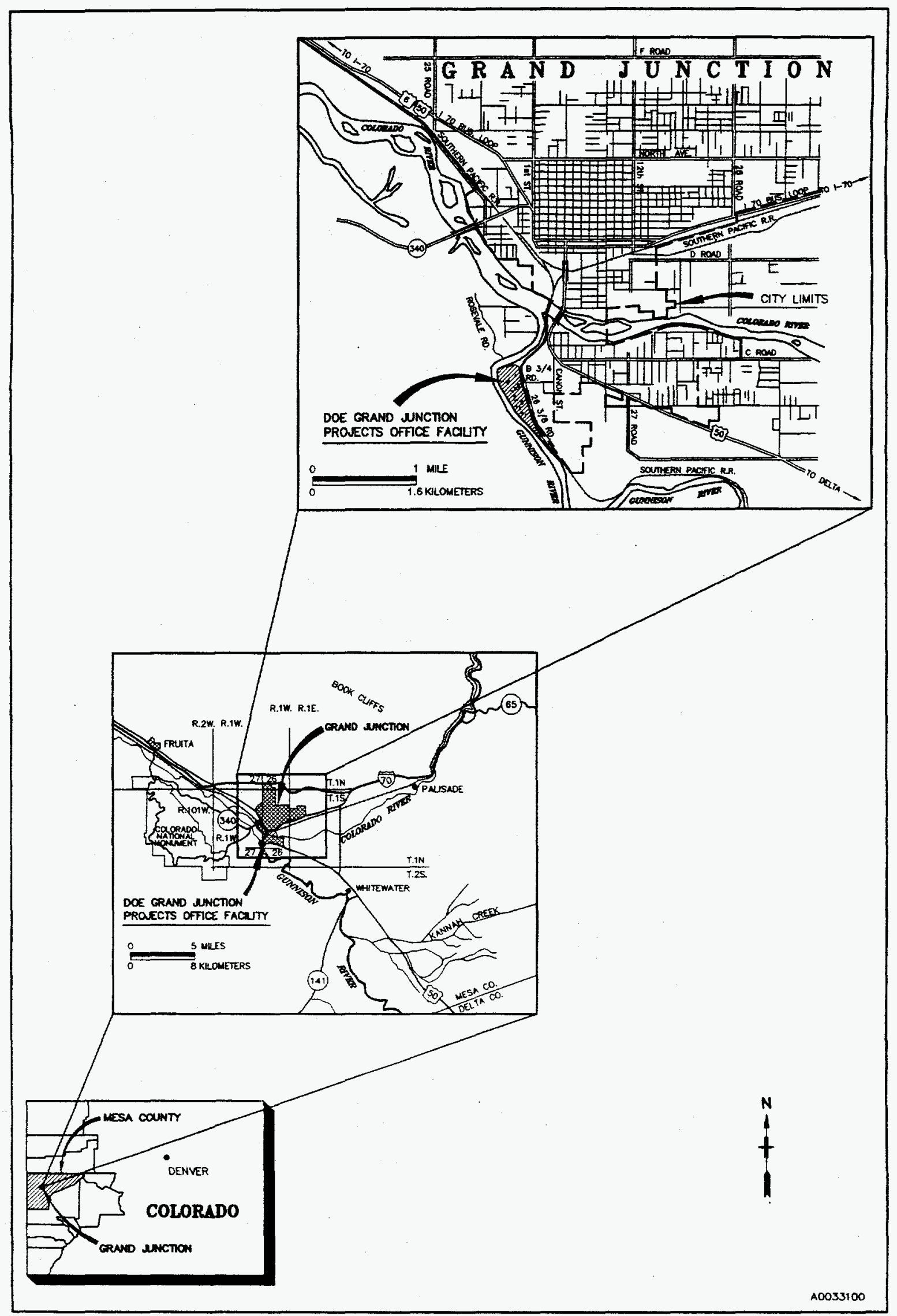

Figure 1. DOE Grand Junction Projects Office Facility Location Map 
maintained by DOE and its predecessor agencies, the U.S. Atomic Energy Commission and the U.S. Energy Research and Development Administration), approximately 29,024 metric tons (32,000 short tons) of ore was processed between 1943 and 1958. The resulting tailings, consisting of approximately 136,100 cubic meters (178,000 cubic yards) of material, was distributed throughout the site.

Site characterization and remedial action studies to assess the radiological hazards at the facility began in 1984 when the facility was accepted into the DOE Surplus Facilities Management Program. Results of these studies were presented in the Radiologic Characterization of the U.S. Department of Energy Grand Junction Projects Office Facility (Henwood and Ridolfi 1986). In 1988, the facility was transferred to the Defense Decontamination and Decommissioning Program; this DOE Headquarters (HQ) organization was restructured in November 1990. Cleanup of the facility is now overseen by the Division of Southwestern Area Programs, Decontamination and Decommissioning Program, in the DOE Office of Environmental Restoration.

In planning for cleanup of the facility, DOE-GJPO complied with the National Environmental Policy Act (NEPA) process and also elected to comply with the Comprehensive Environmental Response, Compensation, and Liability Act (CERCLA) even though the site did not qualify for placement on the National Priorities List. A Final Remedial Investigation/Feasibility Study-Environmental Assessment (RI/FS-EA) that addressed remediation of the facility was completed in 1989 (DOE 1989a). Removal of contaminated soils from open-land areas began in 1989 and was completed in June 1994 (Figure 2). Cleanup of contamination in and beneath on-site buildings is ongoing.

Rust Geotech, the operating contractor for DOE-GJPO, prepared this annual Site Environmental Report for the GJPO facility. This report presents information pertaining to environmental activities conducted during calendar year 1995 at the GJPO facility and is organized into the following major sections: 2.0, "Compliance Summary"; 3.0, "Environmental Program Information"; 4.0, "Environmental Radiological Program Information"; 5.0, "Environmental Nonradiological Program Information"; 6.0, "Groundwater Monitoring and Protection Program"; 7.0, "Quality Assurance"; Appendix A, "Monitoring Data"; Appendix B, "Time-Concentration Graphs"; and Appendix C, "Well Location Maps Showing Groundwater Analytes That Exceed Federal or State Standards."

Section 2.0, "Compliance Summary," summarizes the GJPO facility's compliance with Federal, State, and local environmental requirements for the period January 1, 1995, through December 31, 1995. This section includes descriptions of the GJPO waste management programs and a list of environmental permits issued to the GJPO by Federal, State, and local regulatory agencies.

Section 3.0, "Environmental Program Information," includes (1) a description of the contamination present at the site; (2) a summary of meteorological, sewer effluent, 


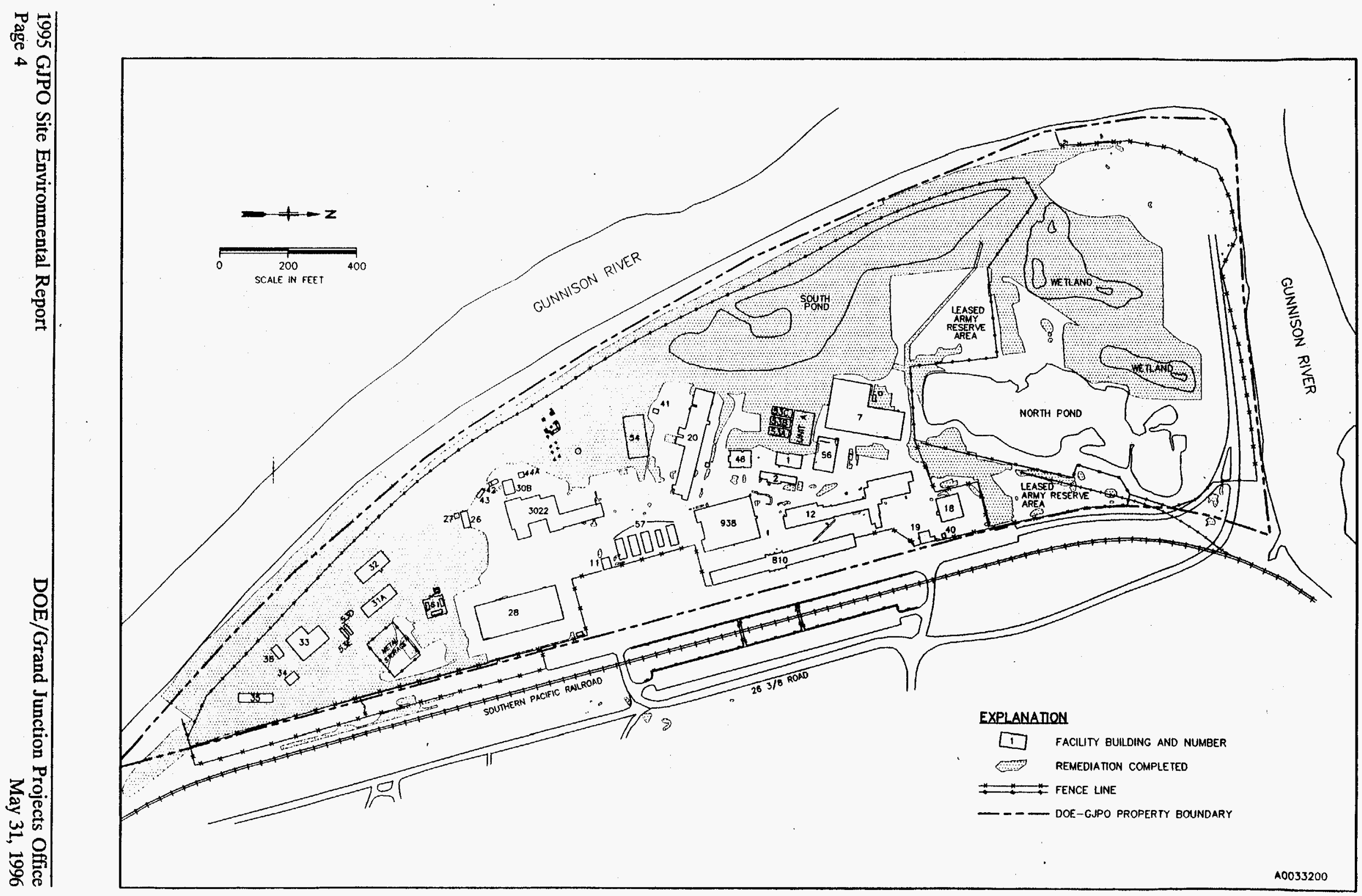

Figure 2. Formerly Contaminated Areas of GJPO Facility Remediated as of June 1994 
storm-water effluent, and surface-water monitoring performed on and near the site, including a discussion of how monitoring results compare with applicable standards; (3) a list of environmental documents completed in 1995 pertaining to site activities; and (4) a summary of significant environmental activities occurring at the site during 1995.

Section 4.0, "Environmental Radiological Program Information," summarizes radiological monitoring results and off-site dose modeling. Section 5.0, "Environmental Nonradiological Program Information," summarizes nonradiological monitoring results.

Section 6.0, "Groundwater Monitoring and Protection Program," describes the hydrogeology at the GJPO facility and the program conducted to monitor groundwater. This section compares analytical results of groundwater monitoring with Federal and State standards, and identifies contaminant concentrations in groundwater.

Section 7.0, "Quality Assurance," summarizes the measures taken to ensure the quality of monitoring data collected at and near the GJPO facility. This section also includes results of the participation of the on-site Analytical Chemistry Laboratory in interlaboratory quality assurance (QA) programs.

Section 8.0, "References," contains a list of references cited in this report.

Section 9.0, "Distribution List," identifies the organizations and selected individuals who will receive copies of this report.

Appendix A, "Monitoring Data," provides analytical data collected during 1995. These data are organized according to the medium sampled and include sewer effluent, surface water, and groundwater data.

Appendix B, "Time-Concentration Graphs," graphically presents groundwater and surface-water data from selected locations to show changes in analyte concentrations over time. Collected data are compared to applicable State or Federal standards.

Appendix C, "Well Location Maps Showing Groundwater Analytes Exceeding Federal and State Standards," present the results of each of the 1995 groundwater sampling events. 


\subsection{Compliance Summary}

\subsection{Compliance Status}

The compliance status in 1995 for each of the major environmental statutes and Executive Orders applicable to the GJPO facility is outlined in this section.

\subsubsection{Comprehensive Environmental Response, Compensation, and Liability Act}

Although the GJPO facility was not placed on the National Priorities List by the U.S. Environmental Protection Agency (EPA), DOE-GJPO elected to follow the CERCLA process for environmental cleanup of the facility. The Grand Junction Projects Office Remedial Action Project (GJPORAP) was initiated to remove contaminated materials associated with past uranium-milling activities on site. An RI/FS-EA (DOE 1989a) was completed in 1989, and a Record of Decision (DOE 1990) was finalized and approved by the DOE Idaho Operations Office in April 1990.

GJPORAP activities in 1995 included restoring riparian vegetation along the dike, reseeding wildland grass species in the Treasure Island area, and removing contaminated materials from Buildings 18 and 28. During the year, 394 metric tons (434 tons) of contaminated material was removed and transported to the Uranium Mill Tailings Remedial Action (UMTRA) Cheney Disposal Cell, located 17 miles southeast of Grand Junction.

The GJPORAP Information Repositories were updated in March, June, and September 1995. The repositories are located at the Mesa County Library in Grand Junction and in the Technical Library at the GJPO.

\subsubsection{Superfund Amendments and Reauthorization Act, Title III}

DOE-GJPO developed a Chemical Tracking System in 1995 to comply with the reporting and notification requirements of the Superfund Amendments and Reauthorization Act of 1986 (SARA), Community Right-To-Know Act of 1986 (Sections 311, 312, and 313). The purposes of the Chemical Tracking System are to track the chemicals purchased for use at the GJPO and to assist DOE in meeting the reporting requirements of SARA, Title III.

In accordance with SARA, Title III, Sections 311 and 312, DOE-GJPO submitted a Tier II report for calendar year 1994 to the Colorado Emergency Response Commission, the Mesa County Emergency Planning Committee, and the Grand Junction Fire Department on March 1, 1995. In 1994, diesel fuel was the only chemical regulated by SARA, Title III, that was stored on site in excess of the threshold amounts established by EPA. In 1995, DOE-GJPO did not store any chemicals in excess of the applicable thresholds. 
DOE was not required to submit a Section 313 report in 1995 because the GJPO did not "manufacture, process, or otherwise use toxic chemicals" regulated by SARA, Title III, in excess of its applicable threshold during 1994. The threshold for the GJPO facility is 4,540 kilograms $(\mathrm{kg})(10,000$ pounds $)$ during a calendar year.

During 1995, extremely hazardous substances (EHS) or hazardous chemicals were not stored at the GJPO facility in amounts exceeding the threshold planning quantities established in Sections 311 and 312 of SARA Title III. In addition, toxic chemicals were not used at the GJPO in excess of applicable threshold quantities established in Section 313 of SARA Title III, and no reportable releases of hazardous substances (as defined by Section 304 of SARA Title III) occurred at the GJPO facility; therefore, the applicability of SARA Title III reporting requirements for calendar year 1995 is as follows:

- $\quad$ Sections 302-303: Planing Notification-not required

- Section 304: EHS Release Notification-not required

- Sections 311-312: Material Data Safety Sheets/Chemical Inventory-not required

- Section 313: Toxic Chemical Release Inventory (TRI) Reporting-not required

\subsubsection{Resource Conservation and Recovery Act}

DOE-GJPO operates under the special requirements (codified at Title 40, Section 261.5, of the U.S. Code of Federal Regulations) for conditionally exempt small quantity generators (CESQGs) of hazardous and mixed-waste. The GJPO maintains CESQG status providing the facility generates no more than $100 \mathrm{~kg}$ (220 pounds) of hazardous and mixed-waste in a calendar month. CESQG wastes are not subject to full regulation under 40 CFR 124, 262 through 266, 268, and 270; however, the generator must comply with certain requirements. CESQGs can accumulate waste on site and remain exempt from full regulation as long as accumulated wastes do not exceed $1,000 \mathrm{~kg}$ $(2,200$ pounds). If on-site waste accumulation exceeds $1,000 \mathrm{~kg}$, all of the accumulated wastes become subject to small quantity generator (SQG) requirements, including the land disposal restrictions (LDRs) codified at 40 CFR 268.

In 1991, DOE-GJPO identified and managed (during the course of on-site mill tailings remediation) a quantity of mixed-waste that exceeded the amount allowable under the special requirements for a CESQG. As a result, all hazardous and mixed-waste accumulated on site became subject to SQG requirements. Lacking available mixedwaste treatment capacity, DOE-GJPO was in jeopardy of exceeding the allowable onsite accumulation period of 270 days; therefore, DOE submitted a Resource Conservation and Recovery Act (RCRA) Part A permit application to the Colorado Department of Public Health and Environment (CDPHE) and EPA Region 8, on January 22,1992 , and officially commenced operation of the hazardous and mixed-waste storage unit (Building 42) as a RCRA interim-status storage facility. Since 1992, DOE has reestablished its CESQG status and continues to maintain that status. 
The wastes generated and in accumulation during DOE's regulated status as a SQG became subject to LDRs. The hazardous wastes were shipped off site, and the mixedwastes remained in storage because suitable treatment capacity could not be identified. The Federal Facility Compliance Act (FFCAct), signed in October 1992, waives sovereign immunity for LDR-waste storage violations (RCRA, Section 3004[j]). However, the FFCAct allows a 3-year delay for DOE storage of mixed-wastes. During this 3-year period, DOE must prepare plans for developing the required treatment capacity for mixed-waste at each site where mixed-wastes have been stored or generated.

In accordance with the "Schedule for Submitting Plans for the Treatment of MixedWaste Generated or Stored at Each Site" (58 Federal Register 17875), DOE-GJPO prepared and submitted conceptual, draft, and proposed Site Treatment Plans to CDPHE. In the DOE-GJPO Proposed Site Treatment Plan (DOE 1995b), DOE stated its intention to accelerate, to the extent possible, the schedules for treating its mixed-waste. The schedules were accelerated so that DOE could demonstrate compliance with LDRs before it became necessary for CDPHE to approve the plan and issue an implementing compliance order. DOE's compliance strategy was (1) to make use of available commercial treatment capacity, (2) to conduct on-site treatability studies in support of the AL Mixed-Waste Treatment Plan (DOE 1994), and (3) to conduct radionuclide separation on specific Analytical Laboratory wastes. On September 29, 1995, DOE provided written notification to CDPHE that it had achieved mixed-waste compliance with LDRs and RCRA, Section 3004(j), and described how DOE intended to maintain compliance with LDR requirements in the future. On November 29, 1995, DOE received written acknowledgment of CDPHE's review and concurrence with DOE's LDR compliance notification. As long as DOE-GJPO maintains its CESQG status, the facility remains exempt from the time restrictions for on-site waste accumulation and from the LDRs and accompanying storage prohibitions.

\subsubsection{National Environmental Policy Act}

During 1995, the Draft Environmental Assessment of Facility Operations at the U.S. Department of Energy Grand Junction Projects Office, Grand Junction, Colorado (DOE 1996) was updated and prepared for public review. This environmental assessment (EA) describes the potential environmental and human health impacts associated with operations at the GJPO facility. The EA is expected to be finalized in 1996.

In 1995,36 proposed actions on the GJPO facility were reviewed for compliance with NEPA requirements in accordance with 10 CFR 1021; DOE Supplemental Directive 5440.1D, U.S. Department of Energy Albuquerque Operations Office NEPA Compliance Program; and DOE Order 451.1, NEPA Compliance Program. Environmental checklists were prepared for 29 of these proposed actions, which are described in the list of categorical exclusions in 10 CFR 1021, Subpart D, Appendix B. The DOE Albuquerque Operations Office (AL) determined that these 29 proposed actions were categorically excluded from further NEPA review. Four of the proposed actions were described in an existing NEPA document or covered by an existing 
categorical exclusion. The remaining three proposed actions were identified as continuations of actions that had already received NEPA approval.

NEPA determinations, reviews, and approvals were tracked and updated on a monthly basis in 1995. In addition, a NEPA Annual Planning Summary, which lists EAs and environmental impact statements to be prepared during the year, was submitted to DOE-AL in January 1995.

\subsubsection{Uranium Mill Tailings Radiation Control Act}

The Uranium Mill Tailings Radiation Control Act of 1978 (UMTRCA) authorized remedial action at certain inactive uranium milling sites that were not owned by the Federal government. Because the GJPO facility is owned by DOE, this is not an applicable requirement; however, UMTRCA is considered a relevant and appropriate requirement for remedial action at the facility. Cleanup of radioactive contamination is conducted in compliance with the standards specified at 40 CFR 192.

\subsubsection{Clean Air Act/National Emission Standards for Hazardous Air Pollutants}

In 1991, CDPHE granted DOE-GJPO an air emission permit for the Analytical Laboratory. The permit established limitations on (1) the annual emissions of particulate matter, volatile organic compounds, and benzene; (2) the annual consumption of acids, volatile organic compounds, and benzene; and (3) the opacity of the emissions. As in previous years, no limits were exceeded in 1995.

Off-site dose modeling using CAP88PC dose assessment software was conducted for the facility to determine compliance with current National Emission Standards for Hazardous Air Pollutants (NESHAP), Subpart H; DOE Order 5400.1, General Environmental Protection Program; and DOE Order 5400.5, Radiation Protection of the Public and the Environment. The total radioparticulate dose to the maximally exposed off-site individual ( 400 meters west-northwest of the GJPO facility) was calculated at $5.19 \times 10^{-5}$ millirem per year (mrem/yr), which is well below the DOE and EPA standard of $10 \mathrm{mrem} / \mathrm{yr}$.

\subsubsection{Clean Water Act/National Pretreatment Program}

Sewer effluent from the facility is routed to the publicly owned treatment works operated by the city of Grand Junction. A Class II Industrial Pretreatment Permit (No. 23REV) was reissued to DOE-GJPO by the city of Grand Junction in February 1993 in accordance with provisions of the Federal Water Pollution Control Act as amended by the Clean Water Act and Article 10 of Chapter 25 of the Code of Ordinance for the city of Grand Junction. The permit requires that the sewer effluent be sampled and measured for biological oxygen demand, oil and grease, polychlorinated biphenyls (PCBs), $\mathrm{pH}$, silver, total suspended solids (TSS), total dissolved solids (TDS), ammonia, temperature, and flow. Threshold limits were assigned to oil and grease, PCBs, $\mathrm{pH}$, silver, and temperature. DOE-GJPO sampled its sewer effluent quarterly and reported 
the results to the city by January 31 , April 30 , July 31 , and October 31,1995 . None of the reported results exceeded established threshold limits (see discussion in Section 3.2.5).

The GJPO facility has no wastewater or storm-water discharges that are regulated by the National Pollutant Discharge Elimination System (NPDES) and, therefore, is not required to have NPDES discharge permits for its current activities and operations. As a best management practice, however, DOE-GJPO has included storm-water monitoring in its comprehensive environmental monitoring plan. One storm-water runoff sample was collected during 1995 (see Section 3.2.6 for monitoring results).

\subsubsection{Clean Water Act/Executive Order 11990, "Protection of Wetlands"}

DOE-GJPO has made provisions to restore all wetland areas that have been disturbed by remedial actions on the facility. Through the U.S. Army Corps of Engineers (COE), DOE obtained a 404 permit for excavation of tailings-contaminated materials in riparian areas along the Gunnison River and in wetland areas. This permit establishes the conditions under which the disturbed areas will be restored. Restoration was completed in spring 1995, and monitoring was initiated in August 1995. Results of the monitoring were documented in the First Annual Monitoring Report for the U.S. Department of Energy Grand Junction Projects Office Wetland Mitigation Project (DOE 1995c).

\subsubsection{Safe Drinking Water Act}

The provisions of the Safe Drinking Water Act are not relevant to the GJPO facility because neither groundwater nor surface water on or near the site is used for public consumption.

\subsubsection{Toxic Substances Control Act}

Actions regulated under the Toxic Substances Control Act (TSCA) that occurred during 1995 included: the continued storage of PCB-contaminated tailings in roll-off bins; the continued storage of radiologically contaminated PCB light ballasts, light fixtures, personal protective equipment (PPE), and PCB-extracted soil residue; and the continued removal of asbestos in and around facility buildings.

In 1989, suspected PCBs mixed with uranium mill tailings were excavated during GJPORAP activities and were unintentionally placed in an on-site temporary stockpile before reviewing the PCB analytical data. Recovery of the PCB-contaminated materials resulted in dilution and volume expansion. Under EPA guidance, these wastes were excavated and later stored in Building 33 in four roll-off bins. The approximately 47 cubic meters (61 cubic yards) of PCB-contaminated material are currently stored in compliance with TSCA in Building 33. It is anticipated that disposal will occur at the UMTRA Cheney Disposal Cell during 1996. 
Approximately $13 \mathrm{~kg}$ (29 pounds) of leaking PCB light ballasts contaminated with tailings material was excavated during GJPORAP activities in May 1994. The ballasts were placed in a 5-gallon drum, which met TSCA-container storage requirements; these ballasts are currently stored in a TSCA-compliant storage facility (Building 42).

In June 1994, $170.6 \mathrm{~kg}$ (375 pounds) of radiologically contaminated PCB light ballasts and fixtures was generated during decontamination of Building 7. In June 1995, a waste minimization effort was implemented to decontaminate this episodically generated waste, and the bulk of the waste was reduced from $170.6 \mathrm{~kg}$ to approximately $20 \mathrm{~kg}$ (44 pounds). The decontaminated portion of the waste was shipped to Rollins Environmental Services, Inc. in Deer Park, Texas, in August 1995. With the exception of the 1-year storage limitation, the remaining waste continues to be stored in compliance with TSCA regulations.

Approximately $72 \mathrm{~kg}$ (158 pounds) of radioactive and PCB-contaminated soil residue, generated from the extraction of PCBs, has been stored at the GJPO since November 1992. Although these materials contain less-than-detectable levels of PCBs, they must continue to be managed as a TSCA-regulated material because of the TSCA "no-dilution" rule. Disposal options for stored radioactive PCB wastes (other than those stored in roll-off bins) are discussed in Section 2.2.2, "Waste Management."

Between May and December 1995, asbestos was removed from Buildings 1, 12, 20, and 938 and was disposed of at the Mesa County landfill in compliance with local, State, and Federal regulations. Work was performed under General Contractor Abatement Certificate No. 84-1034010, issued to Rust by the Air Pollution Control Division of CDPHE on February 22, 1993.

\subsubsection{Federal Insecticide, Fungicide, and Rodenticide Act}

The Federal Insecticide, Fungicide, and Rodenticide Act (FIFRA) governs the use, storage, registration, and disposal of pesticides. FIFRA categorizes pesticides as either "restricted use" or "general use." EPA may classify a pesticide as a restricted-use pesticide (1) if it is determined that substantial adverse effects to the applicator or environment may occur without additional regulatory restrictions or (2) if unreasonable harm to humans or the environment may occur, even if the pesticide is used as directed by the label instructions. FIFRA regulations require that restricted-use pesticides be used or applied only by a certified private or commercial applicator or under the direct supervision of a certified applicator. A restricted-use pesticide, pyrethrum, was applied to the crawl spaces of all GJPO buildings on three occasions in 1995 to eradicate spiders. A certified commercial applicator applied the pesticide in compliance with the provisions of FIFRA.

\subsubsection{Endangered Species Act}

Section 7 of the Endangered Species Act requires DOE to ensure that any actions authorized, funded, or performed at the facility do not "jeopardize the continued 
existence of threatened or endangered species and do not destroy or adversely modify critical habitat required for the continued existence of that species." The Gunnison River adjacent to the facility provides habitat for four endangered fish: the Colorado squawfish, humpback chub, bonytail chub, and razorback sucker. Because withdrawals of water from the river were needed for dust abatement and irrigation at the facility, a biological assessment addressing the effects of the proposed withdrawals on fish habitat was prepared and submitted to the U.S. Fish and Wildlife Service (USFWS) in 1991. The USFWS released a biological opinion and approved the withdrawals with a stipulation that DOE mitigate the effects of its actions on the endangered fish by making payment to the Colorado River recovery fund each year that water is withdrawn. Provisions for payment to the recovery fund were made so that the withdrawal of water from the Gunnison River could continue.

\subsubsection{National Historic Preservation Act}

The National Historic Preservation Act requires DOE to assess the effects of federally assisted actions on a structure or object that is included on or eligible to the National Register of Historic Places. During 1995, no actions affecting such structures or objects occurred on the facility.

\subsubsection{Executive Order 11988, "Floodplain Management"}

The COE determined that the GJPO facility was not on the 100 -year or the 500-year floodplain of the Gunnison River (COE 1976). The Mesa County Housing and Urban Design Flood Insurance Rate Map (July 1978) places the GJPO facility within the 1,000-year floodplain. In accordance with Executive Order 11988, "Floodplain Management," the Mesa County Floodplain Permit Application (DOE 1989b) was prepared, and a permit was obtained in 1989 for the facility and GJPORAP operations.

\subsection{Current Issues and Actions}

\subsubsection{Waste Minimization and Pollution Prevention}

During 1995, a number of actions were implemented on the GJPO facility to minimize waste generation. These activities included (1) substituting nonhazardous materials for hazardous materials in the Analytical Laboratory, (2) installing energy-efficient lighting in buildings, and (3) discontinuing the use of photographic chemicals. Under GJPORAP, the amount of PPE disposed of at the UMTRA Cheney Disposal Cell was reduced, and the amount of uncontaminated materials salvaged (versus disposed of) during building demolition or decontamination was increased. Salvaged material was sold to off-site buyers.

DOE-GJPO participated in several recycling programs during 1995. Fluorescent light bulbs, telephone books, lead-acid batteries, paper, and cardboard generated on the 
facility were recycled. Additionally, DOE assisted other local agencies and companies in coordinating a community household hazardous-waste collection and recycling day.

Three pollution-prevention opportunity assessments were conducted in 1995 to determine if wastes could be minimized or recycled. These assessments resulted in a reduction in solvent use by the Analytical Laboratory and the elimination of solvent use in the paint shop.

\subsubsection{Waste Management}

\section{Hazardous and Mixed-Wastes}

DOE-GJPO maintained its status as a CESQG throughout 1995, generating no more than $100 \mathrm{~kg}$ ( 220 pounds) of hazardous and mixed-waste or $1 \mathrm{~kg}$ ( 2.2 pounds) of acutely hazardous and mixed-waste during any calendar month. Approximately $377 \mathrm{~kg}$ (829 pounds) of hazardous and mixed-waste were generated at the GJPO facility during routine operations of the Mixed-Waste Treatment Program, Analytical Laboratory, Petrology Laboratory, Environmental Sciences Laboratory, and Environmental Instrumentation Laboratory and during activities conducted by Site Management and Records Management organizations. This volume of hazardous and mixed-waste is 20 percent less than the volumes generated in 1993 and 1994. All hazardous and mixedwastes generated on the facility were managed in accordance with the Colorado Hazardous Waste Regulations (6 Colorado Code of Regulations [CCR] 1007-3) and DOE Order 5820.2A, Radioactive Waste Management, and DOE Order 5400.5, Radiation Protection of the Public and the Environment.

DOE-GJPO accumulates waste in commercially manufactured storage modules (Buildings 61A, 61B, and 61C) and in satellite accumulation areas. Hazardous wastes are shipped off site to commercial facilities approximately twice a year. In 1995, DOE made two off-site shipments of hazardous waste to Rollins Environmental Services, Inc., and one off-site shipment of low-level radioactive waste (LLW) and mixed-waste to Diversified Scientific Services Inc. DOE-GJPO also maintains a RCRA Part A-permitted interim-status storage facility (Building 42). DOE has prepared and maintains a closure plan for this facility in accordance with the requirements for closure established at 40 CFR 265, Subpart G.

The DOE-HQ waste moratorium and subsequent implementing memoranda required the development of the Performance Objective for the Certification of Nonradioactive Hazardous Waste (DOE 1995i) to ensure that wastes shipped to off-site facilities not licensed for radioactive wastes are not radiologically contaminated. Implementation of the document was evaluated in a Phase II Appraisal performed in November 1994 by DOE-HQ and DOE-AL. A corrective action plan that addressed the appraisal's findings was submitted in January 1995 and approved in April 1995. In September 1995, the GJPO performance objective was revised to incorporate the requirements of the corrective action plans resulting from the Phase II Appraisal. 
GJPO laboratory operations generated only two mixed-waste streams in 1995, which included liquid scintillation cocktails and atomic absorbtion standards. Liquid scintillation cocktails will be shipped to a commercial facility for treatment and disposal. In accordance with stipulations in DOE Order 5820.2A, the radiological component of the mixed-waste must be returned to DOE-GJPO (the generator) unless an exemption is granted by DOE-AL. Preparation of an exemption to DOE Order 5820.2A was completed in 1995 to allow commercial treatment and disposal of the radioactive component of the waste. The atomic absorbtion standards will undergo radionuclide separation (which is not considered treatment by CDPHE) in the Analytical Laboratory. The liquid- and solid-waste streams resulting from the separation will be managed as hazardous waste and LLW, respectively.

Approximately $175 \mathrm{~kg}$ (385 pounds) of lead-contaminated GJPORAP uranium-milltailings waste, generated under CESQG status, was managed on site in 1995.

Discussions with UMTRA Program management began in October 1995 to allow GJPORAP to use one of the UMTRA Program's subcontractors to treat the wastes with the same stabilization/solidification process proposed for the UMTRA properties. Once successfully treated, these wastes would qualify for disposal at the UMTRA Cheney Disposal Cell as nonhazardous waste. Treatment currently is projected for June 1996.

\section{Low-Level Radioactive Wastes}

Radioactive wastes that are clearly not by-product material do not qualify for disposal at the UMTRA Cheney Disposal Cell and must be managed as LLW. Examples of LLW generated at the GJPO facility during 1995 include the Analytical Laboratory's counting filters, planchettes, latex gloves, paper wipes, glassware, soil sample residues, and resins used for radionuclide separation. These wastes were derived from the analysis of environmental samples received from other DOE sites. The Sample Preparation Plant, which receives and prepares incoming samples for laboratory analysis, also generated LLW in the form of soil sample reject, contaminated sand derived from the cleaning of sample grinders and blenders, and particulate fines that were periodically removed from the Sample Preparation Plant's baghouse. DOE also maintained an inventory of approximately 600 obsolete, depleted, or no-longer-used, sealed radioactive sources. Approximately $800 \mathrm{~kg}$ of LLW was generated at the GJPO during 1995.

Because the GJPO has no on-site disposal capability, LLW generation was minimized to the maximum extent possible. Two radiological sorting and surveying exercises were performed in October 1994 and September 1995 that substantially reduced the volume of waste previously managed as radioactive. In addition, stricter requirements were placed on radiological characterization of PPE and trash from radiological areas, which effectively reduced the amount of LLW generated from routine activities.

In 1995, DOE began pursuing an Interagency Agreement with the Kansas City District COE that would enable DOE to ship LLW to a commercial disposal facility (Envirocare of Utah) under an existing disposal contract. DOE anticipates making an LLW shipment in late 1996. 
DOE is pursuing disposal of its sealed radioactive sources at the Nevada Test Site (NTS) by making use of the Pantex Plant's existing NTS approval of an identical waste stream. Recent discussions with NTS Radioactive-Waste Acceptance Program personnel suggest NTS is receptive to this approach. Characterization of DOE's sources in accordance with Pantex's approval procedures is ongoing, and a tentative shipping date has been established for June 1996.

\section{Radioactive PCB Wastes}

Limited treatment availability and capacity for radioactive PCB waste has caused the GJPO to store approximately $72 \mathrm{~kg}$ (158 pounds) of PCB-extracted soil residue and $32 \mathrm{~kg}$ (70 pounds) of radiologically contaminated PCB light ballasts, light fixtures, and PPE beyond the TSCA-allowable 1-year storage limit.

Disposal options for the PCB-extracted soil residue are described in the Treatment, Storage, and Disposal Plan for GJPO Toxic, Hazardous, Radioactive, and Mixed Wastes (DOE 1995j). DOE's two disposal options are: (1) develop a position paper emphasizing the absence of PCBs in the waste (because PCBs were fully extracted from the soil during the laboratory procedure) and, upon EPA approval, dispose of the waste as LLW; and (2) await promulgation of a proposed TSCA rule that would exempt laboratory extraction residues from regulation.

The only option currently identified for the radiologically contaminated PCB light ballasts, light fixtures, and PPE appears to be use of the DOE Oak Ridge Operations Office (ORO) TSCA incinerator. ORO anticipates that the TSCA incinerator will be available to treat non-ORO-generated, noncombustible, RCRA mixed and radioactive PCB solid wastes in fiscal year 1999.

\subsubsection{Mixed-Waste Treatment Program}

In 1994, DOE-AL assigned DOE-GJPO Overall Program Manager responsibility for implementing the $A L$ Mixed-Waste Treatment Plan (DOE 1994). This plan establishes an approach for creating timely and cost-effective treatment capacity for facilities under DOE-AL oversight that store or generate mixed-wastes. DOE-GJPO also was assigned responsibility for designing and fabricating three mobile treatment unit technologies and for implementing a sort, survey, and decontamination project. These combined responsibilities and functions resulted in the creation of the GJPO Mixed-Waste Treatment Program.

In March 1994, DOE-GJPO provided written notification to CDPHE of its intention to conduct mixed-waste treatability studies on site in support of its assignment to design and fabricate mobile treatment units. Treatability studies on mixed-waste samples, originating from both the GJPO facility and off site, were initiated in October 1994. These studies are expected to conclude in 1996. Treatability studies conducted during 1995 made use of pilot-scale evaporative-oxidation and thermal-desorption units and 
bench-scale stabilization. At the completion of each treatability study, all unused sample portions, treatment residues, and treated wastes from off-site samples were returned to the sample originators. Treatability studies were conducted in accordance with the requirements of "Samples Undergoing Treatability Studies at Laboratories and Testing Facilities" in 6 CCR 1007-3, Section 261.4(f)(1) through (14).

In March 1995, DOE-GJPO submitted a report to CDPHE that addressed the treatability studies conducted during calendar year 1994. The report also contained estimates of the number and types of studies to be conducted as well as estimates of the amount of waste expected to be used in treatability studies during 1995.

\subsubsection{Environmental Audits}

During 1995, four audits of GJPO facility operations were conducted: two external audits of the Analytical Laboratory and two internal audits of the GJPO's hazardous-material transportation activities and Chemical Tracking System.

On March 15 and 16, 1995, Lockheed Idaho Technology Company (LITCO) evaluated the capabilities of the Analytical Laboratory to perform inorganic and radiochemical analyses on environmental and waste samples from the Idaho National Engineering Laboratory. No findings and three observations were identified during the assessment. All observations were responded to and closed by July 19, 1995. As a result of this assessment, the Analytical Laboratory was added to LITCO's list of approved laboratories.

From April 10 through 14, 1995, EG\&G Rocky Flats, Inc., assessed the Analytical Laboratory's compliance with EG\&G Rocky Flats Plant quality program requirements associated with isotope radiochemistry. The audit team identified 28 minor findings. All findings were resolved by December 1995.

From March 27 through 29, 1995, Rust QA coordinators conducted an audit of hazardous-material transportation activities on the GJPO facility. No findings and three observations were identified. Rust personnel were commended for fully implementing the DOE requirements associated with hazardous material transportation. No response to the observations was required.

Rust QA coordinators conducted an audit of the facility's Chemical Tracking System in November 1995. One finding concerning the written procedures for the system was identified. The finding was closed in February 1996.

\subsubsection{Management Compliance Assessments}

Management compliance assessments were initiated in March 1991 at the GJPO facility to provide a comprehensive review of activities associated with environmental protection, safety and health, management systems, and organizational structure. The objectives of the assessments are to achieve the highest level of safety for the public and for facility 
employees, to protect the environment, and to provide feedback to management for the improvement of compliance and operations at the facility.

During 1995, 111 management compliance assessments were conducted for a variety of programs and activities. The assessments focused on management and organizational structure, health and safety, and environmental concerns. No conditions imminently hazardous to the environment or to health and safety were identified, although corrective actions were implemented as a result of the assessments.

\subsubsection{Environmental Compliance Tracking Systems}

Two environmental compliance tracking systems were implemented or developed at the GJPO during 1995: (1) Environmental Standards and Assessment Tracking (ESAT) System and (2) Environmental Tracking System (ETS).

Environmental Standards and Assessment Tracking System-The ESAT System is an electronic tracking system designed as a communication tool to advise project and program managers of new and revised environmental standards that may affect the scope, schedule, or budget of planned project activities. This system allows managers to determine the impacts of environmental standards on projects and programs and provides documentation to support necessary schedule and budget changes. In addition, the timely notification provided by the ESAT System allows projects to remain in compliance with applicable standards, which reduces the risks and liabilities associated with noncompliance.

The ESAT System functions by providing E-mail notification to appropriate project and program managers. This notification includes a summary of each new or revised standard and its potential applicability to a project or program. In 1995, Phase I of the ESAT System was implemented; this phase allows data input and provides management notification of new or revised standards. Phase II of the system, which involves generation of monthly reports and individual access to the system, will be operational in 1996.

Environmental Tracking System-The ETS database tracks all environmental activities at the GJPO and provides notification of due dates for deliverables such as permits, notifications, reports, certifications, manifests, and action items. ETS development commenced in 1995 and is scheduled to be completed and fully operational in 1996.

\subsection{Summary of Facility Permits}

GJPO facility permits active during the 1995 calendar year are identified in Table 1. 
Table 1. GJPO Facility Permits Active during 1995

\begin{tabular}{|c|c|c|c|c|c|}
\hline Permit Type & Permit No. & Issuing Agency & Purpose of Permit & Issue Date & Expiration \\
\hline Well & $\begin{array}{l}\text { 039687-M } \\
\text { through } \\
\text { 039733-M }\end{array}$ & $\begin{array}{l}\text { Colorado Division } \\
\text { of Water Resources }\end{array}$ & $\begin{array}{l}\text { Regulates the installation and abandonment of } \\
\text { monitoring wells present at the GJPO facility } \\
\text { as of September } 1991\end{array}$ & Sept. 1991 & None \\
\hline Well & 166057 & $\begin{array}{l}\text { Colorado Division } \\
\text { of Water Resources }\end{array}$ & $\begin{array}{l}\text { Regulates the installation and abandonment of } \\
\text { monitoring well 8-4S at the GJPO facility }\end{array}$ & Sept. 1992 & None \\
\hline Well & 169948 & $\begin{array}{l}\text { Colorado Division } \\
\text { of Water Resources }\end{array}$ & $\begin{array}{l}\text { Regulates the installation and abandonment of } \\
\text { monitoring well 14-6NA at the GJPO facility }\end{array}$ & May 1993 & None \\
\hline Well & $\begin{array}{c}182308 \text { through } \\
182317 \\
(9 \text { permits) }\end{array}$ & $\begin{array}{l}\text { Colorado Division } \\
\text { of Water Resources }\end{array}$ & $\begin{array}{l}\text { Regulates the installation and abandonment of } \\
\text { monitoring wells installed at the GJPO facility } \\
\text { during } 1994\end{array}$ & Oct. 1994 & None \\
\hline Gravel Pit & $037845-F$ & $\begin{array}{l}\text { Colorado Division } \\
\text { of Water Resources }\end{array}$ & $\begin{array}{l}\text { Required for evaporative losses of groundwater } \\
\text { where excavations are not backfilled }\end{array}$ & Oct. 1990 & $\begin{array}{l}\text { Upon } \\
\text { completion of } \\
\text { work }\end{array}$ \\
\hline Pond & $\begin{array}{l}044269-F \text { and } \\
044270-F\end{array}$ & $\begin{array}{l}\text { Colorado Division } \\
\text { of Water Resources }\end{array}$ & $\begin{array}{l}\text { Required for evaporative losses of groundwater } \\
\text { where it is exposed in a pond }\end{array}$ & Nov. 1994 & None \\
\hline $\begin{array}{l}\text { Section } 401 \\
\text { Water Quality } \\
\text { Certification }\end{array}$ & 2030 & CDPHE & $\begin{array}{l}\text { Describes required notifications, restrictions, } \\
\text { and control measures for tailings removal and } \\
\text { transportation }\end{array}$ & Dec. 1988 & $\begin{array}{l}\text { Upon } \\
\text { completion of } \\
\text { work }\end{array}$ \\
\hline $\begin{array}{l}\text { Floodplain } \\
\text { Development }\end{array}$ & $\begin{array}{l}\text { F } 1-89 \\
\text { reissued as } \\
\quad \text { F } 1-90\end{array}$ & $\begin{array}{l}\text { Mesa County } \\
\text { Engineering } \\
\text { Department }\end{array}$ & $\begin{array}{l}\text { Allows reconstruction of the flood control dike } \\
\text { along the Gunnison River }\end{array}$ & $\begin{array}{l}\text { March 1989; } \\
\text { reissued } \\
\text { Feb. } 1990\end{array}$ & $\begin{array}{l}\text { Upon } \\
\text { completion of } \\
\text { work }\end{array}$ \\
\hline $\begin{array}{c}\text { Class II } \\
\text { Industrial } \\
\text { Pretreatment }\end{array}$ & 23REV & $\begin{array}{c}\text { City of } \\
\text { Grand Junction }\end{array}$ & $\begin{array}{l}\text { Allows GJPO facility to discharge into the } \\
\text { Grand Junction sewer system }\end{array}$ & $\begin{array}{l}\text { March 1989; } \\
\text { revised } \\
\text { Feb. } 1993\end{array}$ & May 1996 \\
\hline 404 & 10040 & COE & $\begin{array}{l}\text { Required for remedial excavation of the GJPO } \\
\text { facility dike and areas adjacent to the } \\
\text { Gunnison River }\end{array}$ & $\begin{array}{l}\text { March 1989; } \\
\text { extended in } \\
\text { Feb. 1992; } \\
\text { extended in } \\
\text { June } 1993\end{array}$ & $\begin{array}{l}\text { Dec. } 1991 \\
\text { Nov. } 1993 \\
\text { Nov. } 1996\end{array}$ \\
\hline
\end{tabular}


Table 1 (continued). GJPO Facility Permits Active During 1995

\begin{tabular}{|c|c|c|c|c|c|}
\hline Permit Type & Permit No. & Issuing Agency & Purpose of Permit & Issue Date & Expiration \\
\hline Air Emission & 90ME402-1 & CDPHE & $\begin{array}{l}\text { Limits Analytical Chemistry Laboratory } \\
\text { consumption to } 900 \text { gallons per year (gal/yr) of } \\
\text { acid, } 2,000 \mathrm{gal} / \mathrm{yr} \text { of volatile organic compound, } \\
\text { and } 13 \mathrm{gal} / \mathrm{yr} \text { of benzene; restrictions were met } \\
\text { in } 1995\end{array}$ & $\begin{array}{c}\text { Sept. } 1991 \\
\text { (initial approval) } \\
\text { Jan. } 1994 \\
\text { (final approval) }\end{array}$ & $\begin{array}{l}\text { Upon closure } \\
\text { of the } \\
\text { Analytical Lab }\end{array}$ \\
\hline $\begin{array}{l}\text { Air Emission } \\
\text { (Permit } \\
\text { Exemption) }\end{array}$ & $90 \mathrm{ME} 402-2^{\mathrm{a}}$ & CDPHE & $\begin{array}{l}\text { Limits processing of soil samples to } 66 \text { tons per } \\
\text { year; restrictions were met in } 1995\end{array}$ & Sept. 1991 & Feb. 1994 \\
\hline $\begin{array}{l}\text { Air Emission } \\
\text { (Permit } \\
\text { Exemption) }\end{array}$ & $90 \mathrm{ME} 402-4^{\mathrm{a}}$ & CDPHE & $\begin{array}{l}\text { Limits the facility's consumption to } 12 \mathrm{gal} / \mathrm{yr} \text { of } \\
\text { aqueous ammonium hydroxide, } 200 \mathrm{gal} / \mathrm{yr} \text { of } \\
\text { paints and thinners, and } 55 \mathrm{gal} / \mathrm{yr} \text { of solvent; } \\
\text { restrictions were met in } 1995\end{array}$ & Sept. 1991 & Feb. 1994 \\
\hline Air Emission & 89ME080-1F & CDPHE & $\begin{array}{l}\text { Limits removal of GJPORAP material during } \\
\text { remediation to } 307,495 \text { tons per year (to limit } \\
\text { dust); restrictions were met in } 1995\end{array}$ & $\begin{array}{l}\text { Nov. 1991; } \\
\text { reissued } \\
\text { Nov. } 1994\end{array}$ & $\begin{array}{l}\text { Upon } \\
\text { completion of } \\
\text { GJPORAP }\end{array}$ \\
\hline RCRA & Part A & CDPHE & $\begin{array}{l}\text { Establishes interim status for extended storage } \\
\text { of hazardous and mixed-waste to maintain the } \\
\text { GJPO as a CESQG. }\end{array}$ & Jan. 1992 & $\begin{array}{l}\text { Valid until } \\
\text { CDPHE calls } \\
\text { for a Part B } \\
\text { permit or until } \\
\text { closure of } \\
\text { Building } 42 .\end{array}$ \\
\hline
\end{tabular}

aActivities associated with these permits were exempted from air permit requirements on February 12, 1994. 


\subsection{Environmental Program Information}

\subsection{Sources of Contamination}

A historical survey (McGinley 1987, 1988) and a radiological characterization (Henwood and Ridolfi 1986) were conducted to determine the nature and extent of contaminated materials at the GJPO facility. The historical survey indicated that the pilot-plant operations of the 1940s and 1950s were almost exclusively responsible for the contaminated materials present on site. The radiological characterization summarized the findings of surface-soil surveys, soil borings, subsurface radiological logging, North and South Pond sediment sampling, and building surveys. From these studies and from information generated during initial phases of remedial action at the site, the total volume of uranium tailings and tailings-contaminated material was estimated at 191,000 cubic meters $(250,000$ cubic yards). The tailings and related materials occupied approximately 8 hectares $(20$ acres). Areas of contamination included the North Pond area, the leased U.S. Army Reserve areas, the South Pond area, the dike area along the Gunnison River, and a number of smaller, scattered locations (Figure 2). A critical pathways analysis, which identified sources of radiation and pathways of radiation exposure at the facility, was performed in 1987 and documented in the RI/FS-EA (DOE 1989a).

\subsection{Environmental Monitoring Summary}

\subsubsection{Atmospheric Radon}

An atmospheric radon monitoring program was initiated at the GJPO facility in December 1985 to monitor the impact of GJPORAP contamination on the facility's air quality. This monitoring program was terminated in July 1994 after removal of residual radioactive material from open-land areas of the facility was completed. Atmospheric radon data is not used in dose assessment modeling required by DOE Order 5400.5; this regulation requires data from point sources.

\subsubsection{Air Particulates}

An ambient air-particulate sampling program was initiated at the GJPO facility in December 1985 to monitor the impact of GJPORAP contamination on the facility's air quality. This monitoring program was terminated in July 1994 after removal of residual radioactive material from open-land areas of the facility was completed. Ambient airparticulate data is not used in dose assessment modeling required by NESHAP and DOE Order 5400.5; these regulations require data from point sources. 
Point-source air-particulate emissions from the Baghouse are sampled continuously during Baghouse operation with an automatic sampler. Sampling results are presented in Section 4.1.2, "Air Particulate Emissions."

\subsubsection{Direct Gamma Radiation}

A direct gamma-radiation monitoring program was initiated at the GJPO facility in April 1991 to assess the potential gamma radiation dose to persons on and near the facility. This monitoring program was terminated in July 1994 after removal of residual radioactive material from open-land areas of the facility was completed.

\subsubsection{Meteorology}

Meteorological monitoring was conducted in 1995 at the GJPO facility to support off-site dose modeling. The meteorological monitoring station is located in the northern portion of the facility (Figure 3). New instrumentation was installed in 1993, and monitoring was initiated in November of that year. Parameters measured include wind speed, wind direction, temperature, barometric pressure, precipitation, and relative humidity. Hourly standard deviation of wind direction, which is used to determine atmospheric stability, also was calculated. Wind data collected during 1995 were processed to create a stability array file, which is used for modeling and to create rose diagrams of wind speed and direction (Figure 4). The rose diagrams illustrate the average wind speed from a given direction and the percent frequency of the time that the wind blows from that given direction. Both speed and percent frequency are averaged in 5-degree increments. Although not presented in this report, other meteorological data collected on site can be made available to the interested reader.

\subsubsection{Sewer Effiuent}

In March 1989, a Class II Industrial Pretreatment Permit (No. 23REV) was issued for the GJPO facility by the city of Grand Junction in accordance with provisions of the Clean Water Act of 1977, 40 CFR Part 403, "General Pretreatment Regulations for Existing and New Sources of Pollution," the Colorado Water Quality Control Act, and Article 10 of Chapter 25 of the Code of Ordinance for the city of Grand Junction. Article 10 sets forth uniform requirements for users of city and county publicly owned wastewater treatment works and requires monitoring, enforcement activities, and user reporting.

The industrial pretreatment permit was revised by the city in February 1993. Rather than requiring semiannual sampling, as in the past, the revision required DOE-GJPO to sample its effluent quarterly and to report the results to the city by April 30, July 31, October 31 , and January 31 . The revised permit required measurement of biological oxygen demand, TSS, TDS, ammonia, temperature, $\mathrm{pH}$, oil and grease, silver, and PCBs. Threshold limits were established only for temperature, $\mathrm{pH}$, oil and grease, silver, and PCBs. 


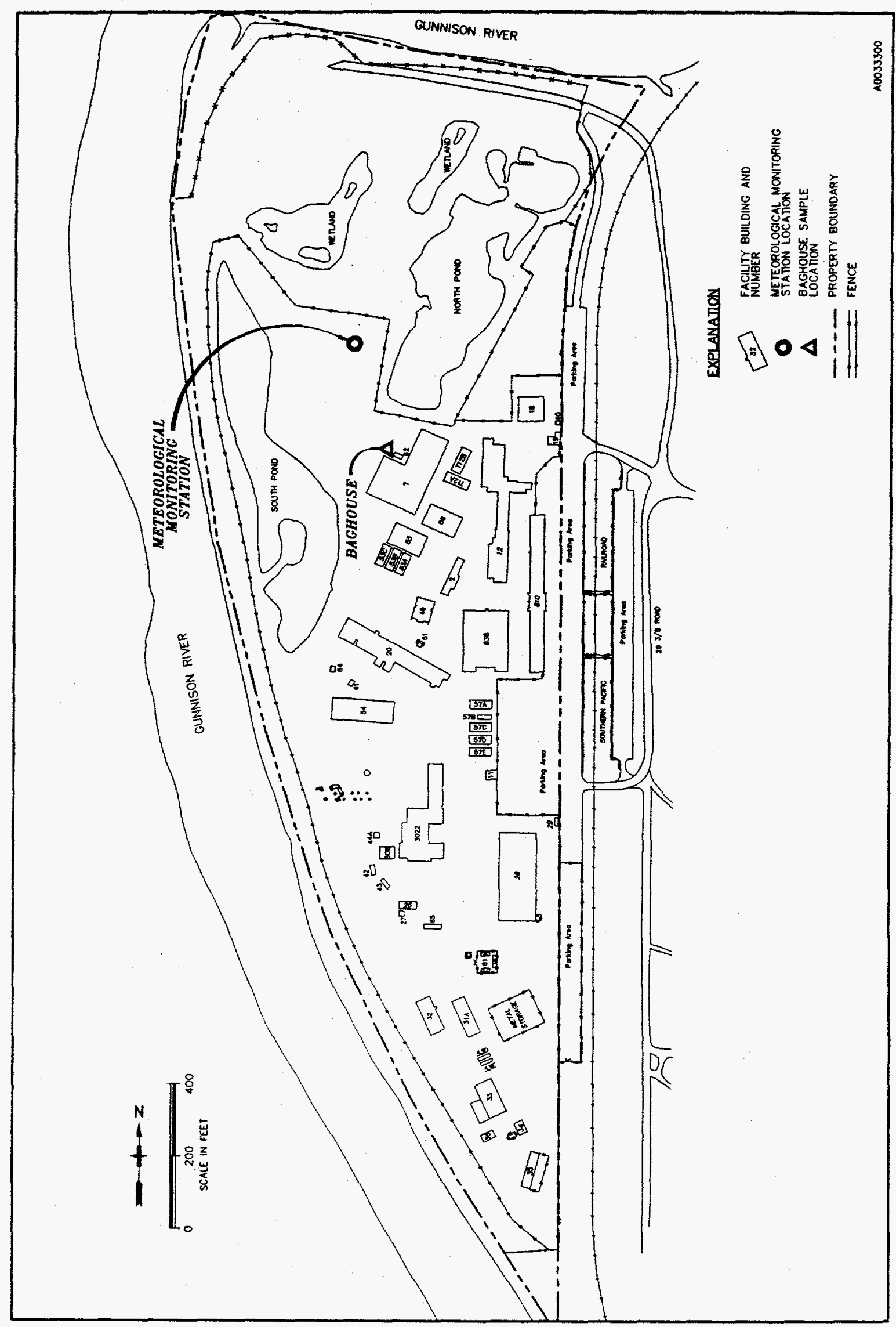



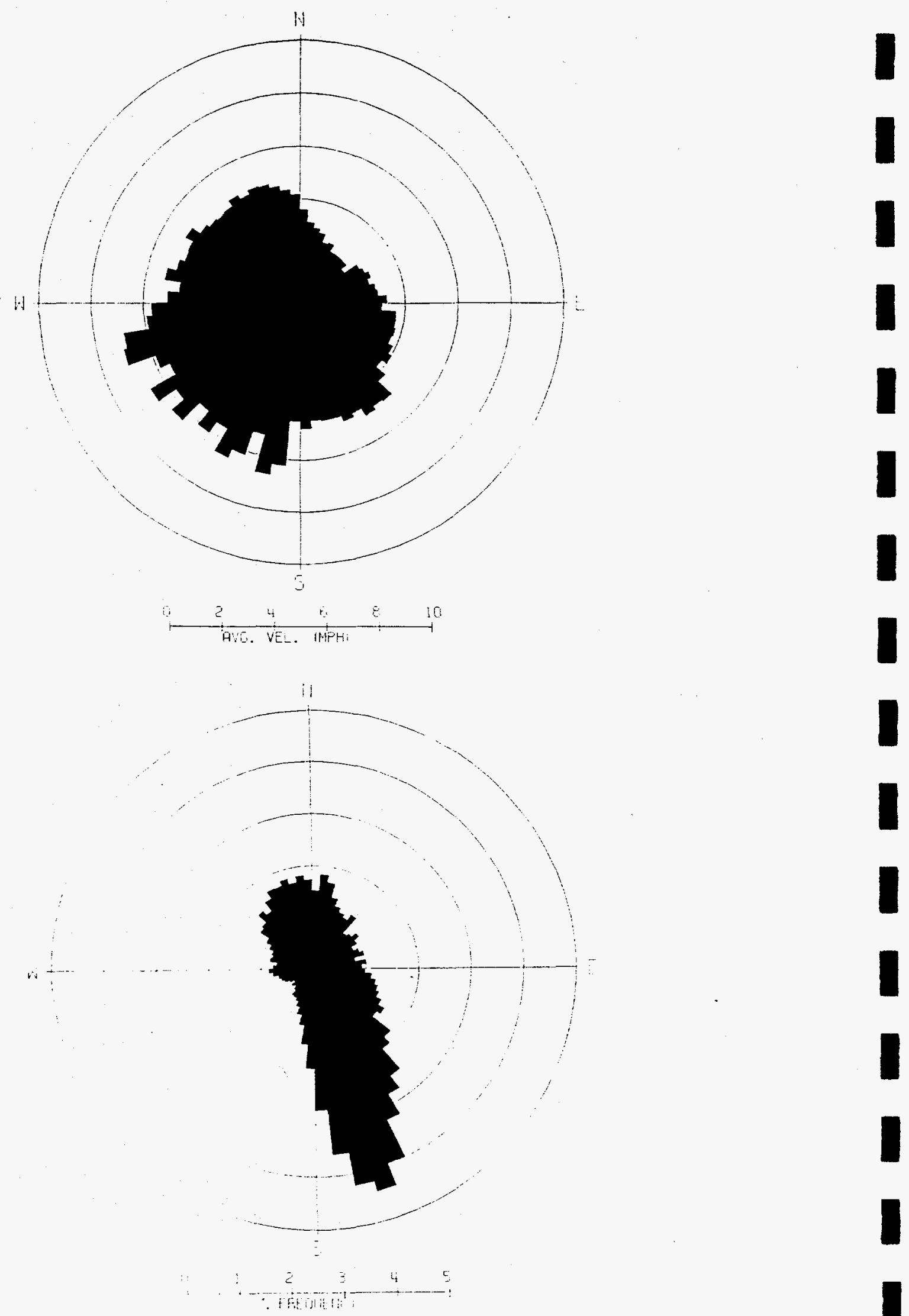

।

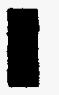

Figure 4. GJPO Wind Speed and Direction 
Sampling was conducted at outfall 001 (Figure 5) in March, June, August, and November 1995; results of the sampling effort were reported to the city on time each quarter. Table 2 summarizes the 1995 sampling results and provides a comparison of these results with established threshold limits. All analyte concentrations were below or within their respective threshold limits. A complete list of sewer-effluent sampling results is provided in Table A-1 in Appendix A.

Table 2. Comparison of Sewer Effluent Threshold Limits to 1995 Maximum Concentrations ${ }^{\mathrm{a}}$

\begin{tabular}{|c|c|c|c|}
\hline Constituent or Parameter & $\begin{array}{c}\text { Threshold } \\
\text { Limit }\end{array}$ & $\begin{array}{l}1995 \mathrm{Ma} \\
\text { Concen }\end{array}$ & $\begin{array}{l}\text { aximum } \\
\text { ttration }\end{array}$ \\
\hline $\begin{array}{l}\text { Ammonia }\left(\mathrm{NH}_{3}\right) \\
\text { Biochemical Oxygen Demand } \\
\text { Oil and Grease } \\
\text { pH } \\
\text { PCBs } \mathrm{C} \\
\text { Silver } \\
\text { Temperature } \\
\text { Total Dissolved Solids } \\
\text { Total Suspended Solids }\end{array}$ & $\begin{array}{l}\text { No Limit } \\
\text { No Limit } \\
50 \quad \mathrm{mg} / \mathrm{L} \\
5.5-9.5 \\
0.002 \mathrm{mg} / \mathrm{L} \\
0.43 \mathrm{mg} / \mathrm{L} \\
40 \quad{ }^{\circ} \mathrm{C} \\
\text { No Limit } \\
\text { No Limit }\end{array}$ & $\begin{array}{l}19.8 \\
90.0 \\
41.4 \\
7.19-7 . \\
<0.002 \\
0.0161 \\
22.5 \\
868 \\
44.0\end{array}$ & $\begin{array}{l}\mathrm{mg} / \mathrm{L} \\
\mathrm{mg} / \mathrm{L} \\
\mathrm{mg} / \mathrm{L} \\
84 \\
\mathrm{mg} / \mathrm{L} \\
\mathrm{mg} / \mathrm{L} \\
{ }^{\circ} \mathrm{C} \\
\mathrm{mg} / \mathrm{L} \\
\mathrm{mg} / \mathrm{L}\end{array}$ \\
\hline
\end{tabular}

\footnotetext{
$a_{A} "<"$ indicates that the maximum concentration was below the detection limit inumber shown is detection limit); "No Limit" indicates no discharge limits were assigned by the city of Grand Junction.

b This represents a maximum quarterly average value.

CPCBs include Aroclor 1016, 1221, 1232, 1242,1248, 1254, and 1260.
}

In addition to the required constituents, flow-proportioned composite samples were collected and analyzed for gross alpha, gross beta, and a selected list of radionuclides (Table A-1). Data from these sampling events were used to assess compliance with DOE Order 5400.5, Radiation Protection of the Public and the Environment, which establishes limits on the discharge of radionuclides into the sewer system. Radiological discharges to the sanitary sewer are discussed in Section 4.1.1, "Liquid Sewage."

\subsubsection{Storm Water}

GJPO facility storm water is collected through a series of drain lines and discharged into the South Pond. Sampling of storm-water effluent was initiated in 1994 in response to an environmental baseline audit finding (DOE 1991). Although the GJPO's storm-water effluent is not subject to EPA's NPDES permitting requirements, the storm-water discharge was sampled as a best management practice. Data collected from sampling 


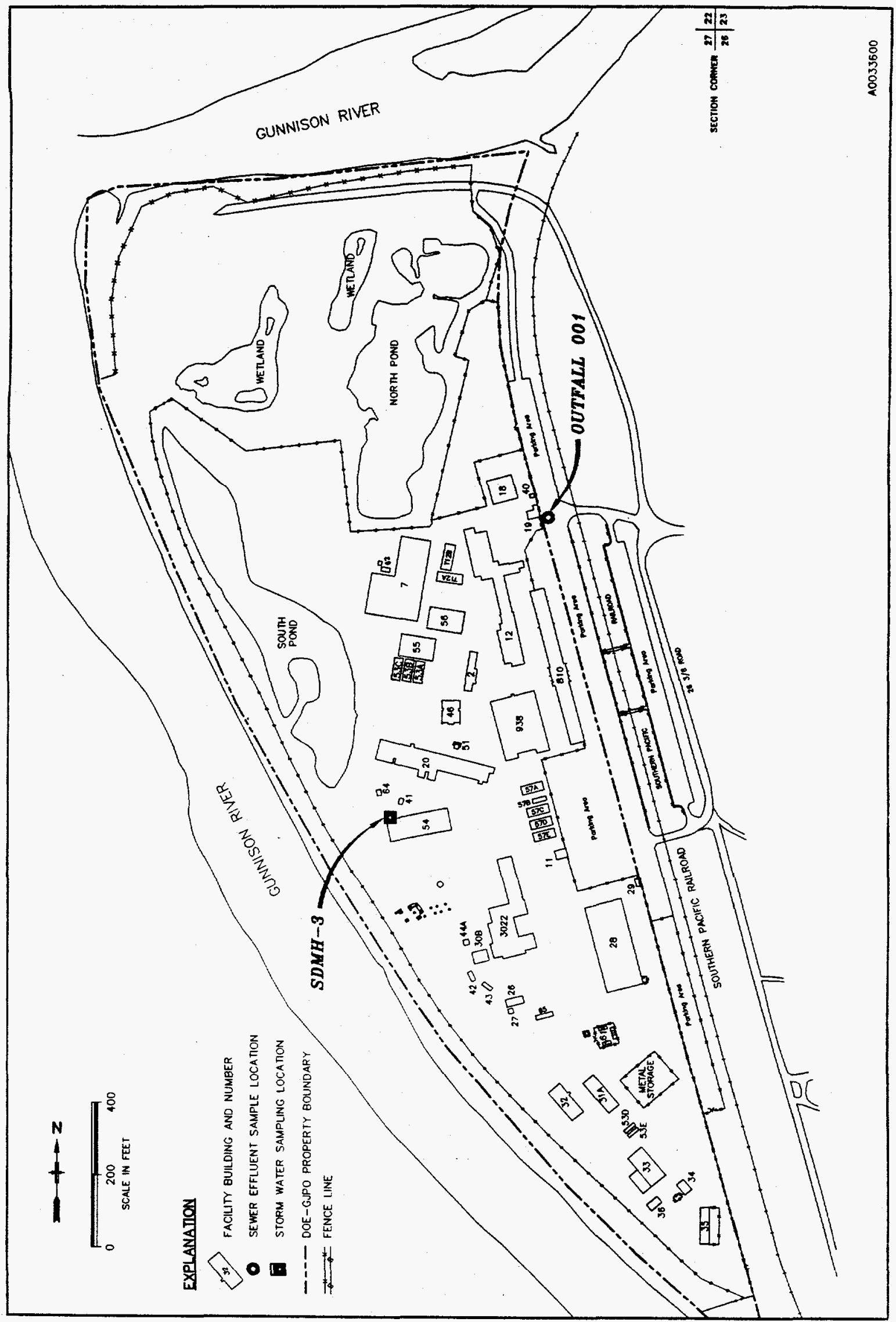

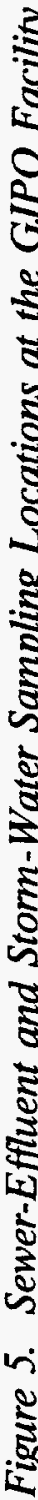


events will be used to establish a water quality baseline for the storm-water effluent and to assess potential effects site activities have on water quality in the South Pond.

One sample and a sample duplicate were collected in December 1995 at the location shown in Figure 5. These samples were collected and analyzed for the constituents listed in Table 3, in accordance with EPA's Guidance Manual for the Preparation of NPDES Permit Applications for Storm Water Discharges Associated with Industrial Activity (EPA 1991). Sampling results indicate that the GJPO storm-water discharge quality is similar to an average residential or commercial site. Average residential and commercial storm-water discharge data were obtained from an EPA study that included sampling data from several sites around the nation (EPA 1983). No radiological data from the EPA study were available for comparison; however, the GJPO storm-water radiological concentrations were near or below detection limits.

Table 3. Results of 1995 Storm-Water Effluent Monitoring a

\begin{tabular}{|c|c|c|c|}
\hline Constituent or Parameter & Result & Reference $b$ & \\
\hline \multicolumn{4}{|l|}{ Nonradiological } \\
\hline $\begin{array}{l}\text { Biochemical Oxygen Demand } \\
\text { Chemical Oxygen Demand } \\
\text { Nitrate + Nitrite (as N) } \\
\text { Phosphorous } \\
\text { Total Kjeldahl Nitrogen } \\
\text { Total Suspended Solids }\end{array}$ & $\begin{array}{l}18.0 \\
90.4 \\
0.727 \\
0.306 \\
1.03 \\
36.0\end{array}$ & $\begin{array}{c}12 \\
94 \\
1.37 \\
0.5 \\
2.3 \\
239\end{array}$ & $\begin{array}{l}\mathrm{mg} / \mathrm{L} \\
\mathrm{mg} / \mathrm{L} \\
\mathrm{mg} / \mathrm{L} \\
\mathrm{mg} / \mathrm{L} \\
\mathrm{mg} / \mathrm{L} \\
\mathrm{mg} / \mathrm{L}\end{array}$ \\
\hline \multicolumn{4}{|l|}{ Radiological } \\
\hline $\begin{array}{l}\text { Radium-226 } \\
\text { Uranium } \mathrm{C}\end{array}$ & $\begin{aligned} & 0.46 \\
< & 0.7326\end{aligned}$ & $\begin{array}{l}\text { None provided } \\
\text { None provided }\end{array}$ & $\begin{array}{l}\mathrm{pCi} / \mathrm{L} \\
\mathrm{pCi} / \mathrm{L}\end{array}$ \\
\hline
\end{tabular}

\footnotetext{
$a_{A}{ }^{~}<{ }^{n}$ indicates that the maximum concentration was below the detection limit (number shown is detection limit).

bReference values for average residential or commercial site concentrations taken from the EPA Nationwide Urban Runoff Program.

CUranium concentration, which was measured in milligrams per liter, was converted to picocuries per liter for comparison purposes. The conversion assumes equilibrium and an activity of 0.666 picocurie per microgram.
} 


\subsubsection{Surface Water}

Surface-water sources at or near the GJPO facility consist of the North Pond, South Pond, Wetland Area, and Gunnison River, all of which contain water perennially. The North Pond, South Pond, and Wetland Area are located on the GJPO facility, and the Gunnison River is contiguous to the facility's west and north boundaries (Figure 6). The wetlands were formed in spring 1994 from the excavation of contaminated soils during GJPORAP operations. This area was not backfilled after excavation, which resulted in a depression that is recharged by groundwater. Although the majority of the wetlands are dry during low groundwater periods (September through March), a portion of the area was designed to contain water year-round for monitoring purposes, which forms the sampling location called the Wetland Area.

Surface-water monitoring is conducted (1) to verify compliance with State water quality standards and (2) to detect changes in water quality resulting from remedial actions. In accordance with the Colorado Water Quality Control Act, four State-use classifications have been designated for the segment of the Gunnison River in the vicinity of the GJPO facility: (1) Recreation-Class I, (2) Cold Water Aquatic Life-Class I, (3) Domestic Water Supply, and (4) Agriculture. Table 4 lists the State water quality standards associated with these classifications. The North Pond, South Pond, and Wetland Area are considered lakes or reservoirs according to the State-use classification system and have been assigned water quality standards for dissolved oxygen, $\mathrm{pH}$, and fecal coliform only.

As remedial activities began at the GJPO facility, the surface-water sampling frequency in 1990 was increased from semiannually to quarterly. This sampling frequency was continued through December 1993, when the sampling strategy was changed to reflect the impending completion of remediation at the facility. The change involved sampling the on-site ponds on a 9-month basis while continuing to monitor the Gunnison River on a quarterly basis. After removal of contaminated soils from open-land areas of the GJPO facility was completed in June 1994, all locations in the surface-water sampling network were placed on a 9-month sampling frequency, which continued with a June sampling event in 1995. A 9-month sampling frequency was implemented to allow assessment of compliance with State water quality standards on an annual basis and to allow seasonal fluctuations in contaminant concentrations to be monitored during a 3-year period.

The surface-water sampling locations are near the shore of the Gunnison River upstream of the facility (Upper Gunnison), adjacent to the facility (two sampling locations-Middle Gunnison and Upper Middle Gunnison), downstream of the facility (Lower Gunnison), near the western shores of the North and South Ponds, and at the newly created Wetland Area (Figure 6). 


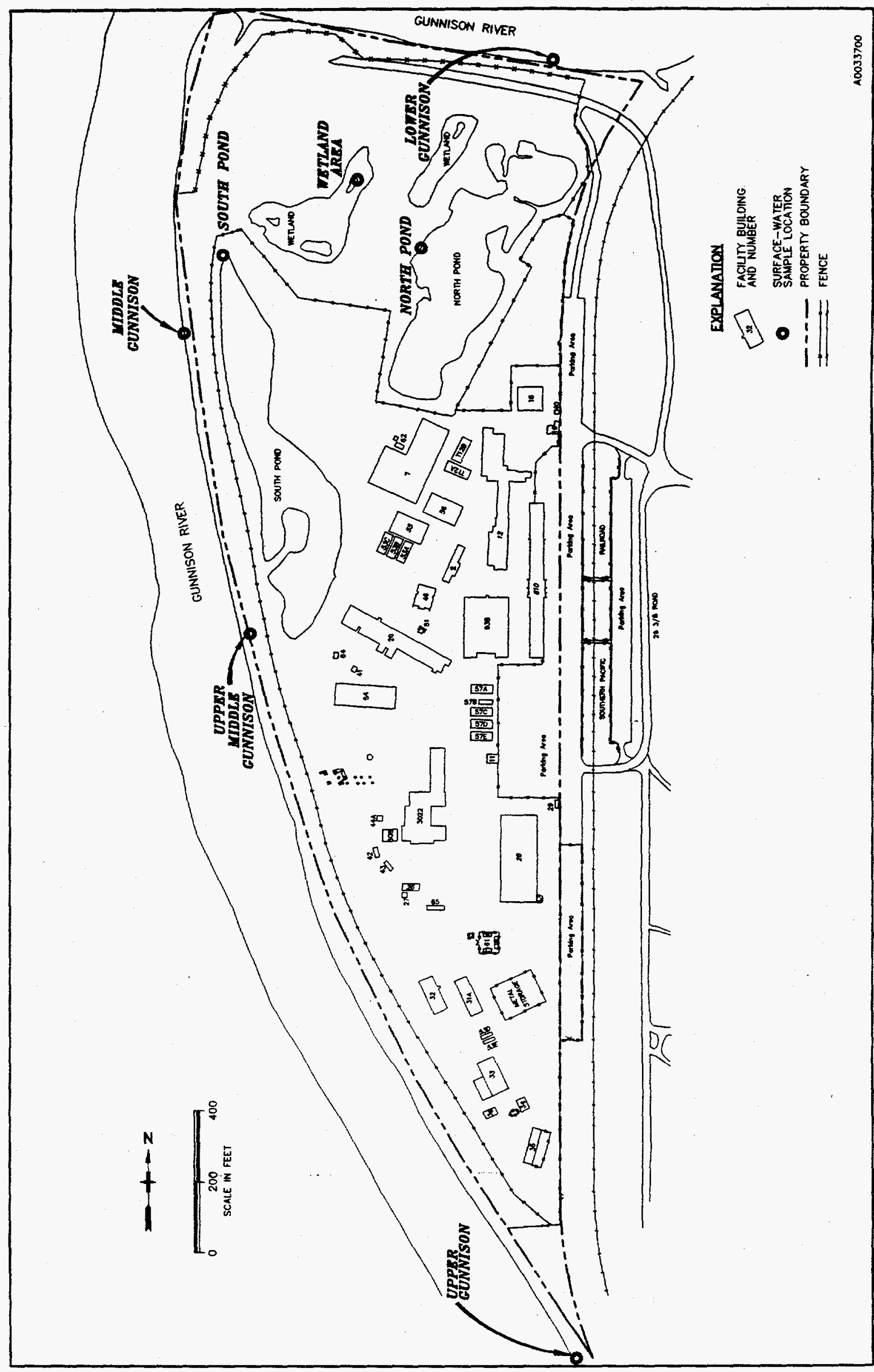




\section{Table 4. Comparison of State of Colorado Surface-Water Quality Standards with 1995 and Historical Maximum Concentrations in Gunnison Rivera,b}

\begin{tabular}{|c|c|c|c|c|c|c|c|c|}
\hline \multirow[b]{2}{*}{ Constịtuent } & & & \multicolumn{3}{|c|}{1995 Maximum Concentrations ${ }^{c}$} & \multicolumn{3}{|c|}{ Historical Maximum Concentrations $c, d$} \\
\hline & \multicolumn{2}{|c|}{$\begin{array}{l}\text { State } \\
\text { Standard }\end{array}$} & $\begin{array}{c}\text { Up- } \\
\text { Gradient }\end{array}$ & $\begin{array}{l}\text { Adjacent } \\
\text { to Site }\end{array}$ & $\begin{array}{c}\text { Down- } \\
\text { Gradient }\end{array}$ & $\begin{array}{c}\text { Up- } \\
\text { Gradient }\end{array}$ & $\begin{array}{l}\text { Adjacent } \\
\text { to Site }\end{array}$ & $\begin{array}{l}\text { Down- } \\
\text { Gradient }\end{array}$ \\
\hline \multicolumn{9}{|l|}{ Common Ions } \\
\hline $\begin{array}{l}\text { Chioride } \\
\text { Nitrate (as N)e } \\
\text { Nitrite (as N)f } \\
\text { Sulfate }\end{array}$ & $\begin{array}{c}250.0 \\
10.0 \\
0.05 \\
250.0\end{array}$ & $\begin{array}{l}\mathrm{mg} / \mathrm{L} \\
\mathrm{mg} / \mathrm{L} \\
\mathrm{mg} / \mathrm{L} \\
\mathrm{mg} / \mathrm{L}\end{array}$ & $\begin{array}{c}1.9 \\
0.22 \\
--- \\
79.3\end{array}$ & $\begin{array}{c}2.0 \\
0.22 \\
-2.5\end{array}$ & $\begin{array}{c}1.9 \\
0.22 \\
-2.6\end{array}$ & $\begin{array}{l}12.4 \\
6 \\
<0.304 \\
513\end{array}$ & $\begin{array}{c}12.6 \\
6 \\
-- \\
512\end{array}$ & $\begin{array}{l}80 \\
6 \\
<0.304 \\
584\end{array}$ \\
\hline \multicolumn{9}{|c|}{ Field Measurements } \\
\hline $\begin{array}{l}\text { Dissoived Oxygeng } \\
\mathrm{pH}\end{array}$ & $\begin{array}{l}6.0 \\
6.5-9.0\end{array}$ & $\mathrm{mg} / \mathrm{L}$ & 7.83 & $7.79-7.92$ & $\overline{7.58}$ & $\begin{array}{c}9.5 \\
7.20-9.04\end{array}$ & $\begin{array}{l}9.3 \\
7.29-9.19\end{array}$ & $\begin{array}{l}9.5 \\
7.33-9.01\end{array}$ \\
\hline \multicolumn{9}{|l|}{ Inorganics } \\
\hline $\begin{array}{l}\text { Fecal Coliform } \\
\text { Metals }^{\text {i }}\end{array}$ & 200 & & $-\cdots$ & --- & -- & 1500 & 300 & 1300 \\
\hline $\begin{array}{l}\text { Arsenic } \\
\text { Cadmium } \\
\text { Chromi um+6 } \\
\text { Copper } \\
\text { Iran } \\
\text { Lead } \\
\text { Manganese } \\
\text { Mercury } \\
\text { Nicke] } \\
\text { Selenium } \\
\text { Silver } \\
\text { Zinc }\end{array}$ & $\begin{array}{l}0.360 \\
0.021 \\
0.011 \\
0.042 \\
0.300 \\
0.032 \\
0.050 \\
0.0001 \\
0.295 \\
0.017 \\
0.001 \\
0.372\end{array}$ & $\begin{array}{l}\mathrm{mg} / \mathrm{L} \\
\mathrm{mg} / \mathrm{L} \\
\mathrm{mg} / \mathrm{L} \\
\mathrm{mg} / \mathrm{L} \\
\mathrm{mg} / \mathrm{L} \\
\mathrm{mg} / \mathrm{L} \\
\mathrm{mg} / \mathrm{L} \\
\mathrm{mg} / \mathrm{L} \\
\mathrm{mg} / \mathrm{L} \\
\mathrm{mg} / \mathrm{L} \\
\mathrm{mg} / \mathrm{L} \\
\mathrm{mg} / \mathrm{L}\end{array}$ & $\begin{array}{l}<0.003 \\
<0.001 \\
<0.004 \\
--- \\
\sim 0.0419 \\
<0.001 \\
0.0256 \\
--- \\
--- \\
\sim 0.0031 \\
--- \\
---\end{array}$ & $\begin{array}{l}\sim 0.0033 \\
<0.001 \\
<0.004 \\
--- \\
\sim 0.0239 \\
<0.001 \\
\sim 0.0095 \\
--- \\
--- \\
\sim 0.0025 \\
--- \\
---\end{array}$ & $\begin{array}{l}<0.003 \\
<0.001 \\
<0.004 \\
--- \\
\sim 0.0058 \\
<0.001 \\
\sim 0.0053 \\
--- \\
--- \\
\sim 0.0028 \\
--- \\
---\end{array}$ & $\begin{array}{l}0.011 \\
0.002 \\
-0.0036 \\
0.056 \\
0.44 \\
0.059 \\
0.2 \\
<0.002 \\
0.005 \\
0.0096 \\
<0.0005 \\
1.07\end{array}$ & $\begin{array}{l}\sim 0.0051 \\
<0.002 \\
\sim 0.0045 \\
0.013 \\
0.1 \\
0.0118 \\
0.0766 \\
<0.002 \\
<0.025 \\
0.014 \\
<0.0005 \\
0.86\end{array}$ & $\begin{array}{ll} & 0.011 \\
<0.002 \\
& 0.0034 \\
0.05 \\
0.32 \\
0.027 \\
0.122 \\
<0.002 \\
0.021 \\
0.0148 \\
0.0005 \\
1.72\end{array}$ \\
\hline \multicolumn{9}{|l|}{ Radiological } \\
\hline Urani um $^{j}$ & 40 & $p C i / L^{k}$ & 1.84 & 1.85 & 1.76 & 10.42 & 14.39 & 22.644 \\
\hline
\end{tabular}

\footnotetext{
aCDPHE Water Quality Control Division standards for the Gunnison River segment, revised January $30,1991$. Not all State standards are 1 isted in this table.

$b_{A}$ ".-." indicates no data were available; a "<" indicates that the maximum concentration was below the detection limit (number shown is detection limit); a " " indicates an approximate value (the value was outside the limits for which the instrument was calibrated).

CThe units are indicated in the "State Standard" colurnn.

Based on maximum concentrations observed from 1980 through 1994.

E $\mathrm{Nitrate}$ (as $N$ ) was derived for measured nitrate using the conversion: nitrate (as $N$ ) $=\mathrm{NO}_{3} \div 4.427$.

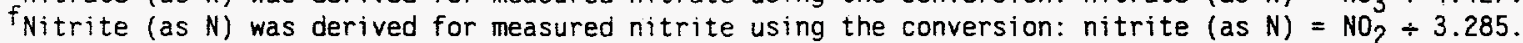

9The standard value for dissolved oxygen represents a minimum concentration. Measured values must be greater than $6.0 \mathrm{mg} / \mathrm{L}$ to comply with this standard. The listed values represent the minimum measurements observed.

himber of colonies per $100 \mathrm{~mL}$.

${ }^{i}$ All values given are for dissolved constituents.

juranium concentrations, measured in milligrams per liter, were converted to picocuries per liter for comparison purposes. The conversion assumes equilibrium and an activity of 0.666 picocurie per microgram.

$\mathrm{k}_{1} \mathrm{pCi} / \mathrm{L}=3.7 \times 10^{-2}$ becquerels per liter.
} 
Surface-water samples were analyzed in the field for alkalinity, $\mathrm{pH}$, conductivity, and temperature; samples were analyzed in the laboratory for metals (arsenic, barium, cadmium, chromium, iron, lead, manganese, molybdenum, selenium, and vanadium), major cations (calcium, magnesium, potassium, and sodium), major anions (chloride, nitrate, and sulfate), radiological analytes (gross alpha, radium-226, radium-228, thorium-230, thorium-232, uranium-234, uranium-235, and uranium-238), TDS, and total organic carbon. These analytes were chosen to characterize general water quality and to monitor the effects of the alluvial groundwater on surface-water quality. Historical and 1995 maximum analyte concentrations in the Gunnison River are summarized and compared with applicable State standards in Table 4. Several constituents listed in the table (such as copper, mercury, nickel, silver, zinc, nitrite, dissolved oxygen, and fecalcoliform) were not measured in 1995 because historically either the standards were not exceeded or a relationship could not be established between alluvial groundwater contamination and concentrations in the Gunnison River. Table A-2 in Appendix A presents surface-water sampling results for 1995.

Analyte concentrations observed in samples from the Gunnison River in 1995 were below or within acceptable ranges of applicable State standards. Historically, manganese and sulfate concentrations have routinely exceeded State standards in samples from all the Gunnison River sampling locations; however, there is no evidence that discharges from the alluvial aquifer are contributing to these elevated concentrations in the river. Figures B-1a through B-1d in Appendix B show measured sulfate concentrations from January 1989 through June 1995 for the Upper, Upper Middle, Middle, and Lower Gunnison River sampling locations.

Uranium concentrations in the Gunnison River may have been affected by alluvial groundwater discharges but not to the extent that state water quality standards were exceeded. Figures B-2a through B-2d in Appendix B show measured uranium concentrations from January 1989 through June 1995 at the four sampling locations on the Gunnison River. Generally, concentrations of uranium are higher in samples from the downstream location than at the upper or middle Gunnison River locations; increases and decreases in uranium concentrations occur at the same time in samples from all four locations. These trends may indicate a discharge of uranium-contaminated groundwater into the Gunnison River. Surface-water concentrations of uranium will continue to be monitored for changes that may occur in response to passive remediation of groundwater at the GJPO facility.

The North Pond, South Pond, and the Wetland Area, which are recharged by the shallow alluvial aquifer underlying the GJPO facility, express some of the same characteristics as the groundwater (see Section 6.0). Like the groundwater, these surface-water features contain elevated quantities of chemical constituents typically associated with uranium mill tailings (e.g., arsenic, manganese, molybdenum, sulfate, uranium, and vanadium). Because the State surface-water standards for ponds and reservoirs (dissolved oxygen, $\mathrm{pH}$, fecal coliform) do not address these constituents, Gunnison River standards were used to evaluate measured concentrations in the North and South Ponds and the Wetland Area. Samples collected from these three areas in 1995 exceeded Gunnison 
River standards for chloride, sulfate, and uranium. Samples collected from the South Pond and Wetland Area also contained manganese concentrations that exceeded the Gunnison River standard. Maximum concentrations were $439 \mathrm{mg} / \mathrm{L}$ of chloride (North Pond); 3,140 mg/L of sulfate (North Pond); $509.15 \mathrm{pCi} / \mathrm{L}$ of uranium (North Pond); and $0.373 \mathrm{mg} / \mathrm{L}$ of manganese (Wetland Area). Figure B-3 in Appendix B shows measured uranium concentrations from January 1989 through June 1995 in the North Pond.

To date, a determination of changes in on-site surface-water quality resulting from remedial actions is premature; only two surface-water sampling events have been conducted since remediation of open-land areas was completed in June 1994. Because the on-site surface-water sources are recharged by alluvial groundwater, surface-water remediation is expected to mirror groundwater remediation; surface-water quality should improve over time as passive remediation of the alluvial aquifer occurs. Groundwater modeling of the alluvial aquifer predicts that groundwater and water in the on-site ponds will be cleaned to below applicable standards within 50 to 80 years of the mill tailings removal.

\subsection{Environmental Documentation}

The following environmental documents were completed or updated in 1995:

- Air Emissions Annual Report (Subpart H, 40 CFR 61.94), Calendar Year 1994 submitted to EPA (DOE 1995a)

- Grand Junction Projects Office Facility, Grand Junction Projects Office Remedial Action Project, Monticello Mill Tailings Site Environmental Monitoring Plan (DOE 1995e)

- Grand Junction Projects Office Radioactive Effluent and On-Site Data Discharge Report, January 1, 1994, through December 31, 1994, for Grand Junction Projects Office, Grand Junction, Colorado, and Monticello Mill Tailings Site, Monticello, Utah (DOE 1995f)

- Grand Junction Projects Office Site Environmental Report for Calendar Year 1994 (DOE 1995g)

- Ground Water Protection Management Program Plan (DOE 1995h)

- Draft Environmental Assessment of Facility Operations at the U.S. Department of Energy Grand Junction Projects Office, Grand Junction, Colorado (DOE 1996) 


\subsection{Environmental Activities}

\subsubsection{Site Management Inspections}

Monthly inspections of the GJPO facility were conducted from January to December 1995. Site management personnel were assisted by DOE and by Rust representatives from Environmental Services; Quality Assurance; and Health, Safety, and Security organizations. With foci on waste management, pollution prevention, safety, and general housekeeping, the inspection team examined work areas, equipment storage areas, aboveground storage tanks, waste storage areas, and ongoing work. An important aspect of the inspections was the identification of potential environmental compliance issues related to the temporary storage of hazardous, radioactive, and mixed-wastes at the GJPO.

\subsubsection{Environmental Training}

Environmental training courses conducted at the GJPO facility during 1995, in compliance with Federal regulations and DOE orders, included

- DOE Pollution Prevention Workshop

- Environmental Awareness Training

- Mixed-Waste Management

- Waste Management Awareness

- Storm-Water Pollution Prevention Inspection

- General Employee Radiological Training

- Radiological Worker II Training

- Radiological Worker Refresher

- Radiological Worker II-Challenge

- Field Source Custodian (Source Handler)

- Hazardous Waste Site Training

- Hazardous Waste Site Refresher

- Hazard Communication Standard

- Respirator Wearer

- Emergency Response Cadre

- Notification and Occurrence Reporting 


\subsection{Environmental Radiological Program Information}

\subsection{Radioactive Effluent Data}

Radioactive effluent is released from the GJPO facility in three forms: liquid sewage, air particulate emissions, and atmospheric radon. Effluent types, emitting sources, and release rates are described in the following sections.

\subsubsection{Liquid Sewage}

Liquid effluent discharge from the GJPO facility to the city sewer system is sampled monthly for gross alpha and gross beta. If the sum of gross alpha and gross beta is equal to or greater than 150 picocuries $(\mathrm{pCi})$ per liter, analyses are performed for those isotopes and elements that are expected to be the principal contributors to the elevated gross alpha and gross beta concentrations. Gross alpha and gross beta values exceeded $150 \mathrm{pCi} / \mathrm{L}$ four times in 1995 . Isotopic and elemental analysis was performed on the first two of these samples and revealed that natural uranium was the principal contributor to the high gross values. Because uranium was the principal contributor to the first two exceedances, the subsequent two exceedances were analyzed for only uranium.

DOE Order 5400.5, Radiation Protection of the Public and the Environment, states that if the total of the fractions of the average concentrations for each radionuclide to its respective Derived Concentration Guide value exceeds 5, then the best available technology (BAT) to control discharges must be implemented. Analysis of the data revealed that the GJPO radiological discharge was below the threshold requiring BAT implementation.

\subsubsection{Air Particulate Emissions}

Two point sources of radionuclide emissions occur on the GJPO facility: the Analytical Laboratory and the Baghouse. Emissions from the Analytical Laboratory result from sample analysis activities, whereas emissions from the Baghouse result from sample preparation activities (i.e., soil sample blending).

Emissions from the Analytical Laboratory are expected to be minimal because analytical procedures are implemented to control the radiological content of samples to prevent unwanted losses and to ensure the accuracy of sample analyses. In response to the low anticipated emission rate from the Analytical Laboratory, EPA waived emission sampling requirements in 1991 in lieu of emission estimating. Baghouse emissions are sampled according to EPA's periodic confirmatory sampling protocol. Because of the extreme difficulty and uncertainty associated with accurately estimating Analytical Laboratory emissions, the emission rate from the Analytical Laboratory is assigned the quantified 
Baghouse emission rate. This approach does not address the intrinsic differences between Analytical Laboratory and Baghouse operations; therefore, Analytical Laboratory emissions are typically overestimated. However, it is generally accepted as an industry standard to overestimate rather than underestimate facility emissions.

Emission data, listed in Table 5, are entered into the dose model CAP88PC to estimate the dose from radioparticulate emissions. Dose modeling results are provided in Section 4.3, "Offsite Dose .Modeling."

Table 5. Release Rates of Airborne Radioparticulates From the GJPO Facility During 1995

Release Rate

Ci/yra $\quad$ g/yrb $\quad$ Half-Life (yr)

\section{Point-Source Emissions}

Actinium-228

Americium-241

Bismuth-211

Bismuth-214

Cesium-137

Cobalt-60

Europium-152

Lead-212

Lead-214

Plutonium-238

Plutonium-239

Polonium-210

Potassium-40

Protactinium-234

Radium-226

Strontium-90

Thallium-208

Thorium-230

Thorium-232

Uranium-234

Uranium-235

Uranium-238

Uranium-Total
$7.86 \times 10^{-8}$

$9.30 \times 10^{-10}$

$1.37 \times 10^{-7}$

$2.02 \times 10^{-7}$

$1.98 \times 10^{-8}$

$1.68 \times 10^{-8}$

$1.59 \times 10^{-7}$

$5.00 \times 10^{-8}$

$1.47 \times 10^{-7}$

$3.62 \times 10^{-10}$

$9.80 \times 10^{-10}$

$2.40 \times 10^{-8}$

$5.60 \times 10^{-7}$

$3.06 \times 10^{-6}$

$1.20 \times 10^{-8}$

$1.01 \times 10^{-8}$

$2.56 \times 10^{-8}$

$2.12 \times 10^{-8}$

$2.28 \times 10^{-9}$

$1.42 \times 10^{-7}$

$6.04 \times 10^{-9}$

$1.40 \times 10^{-7}$

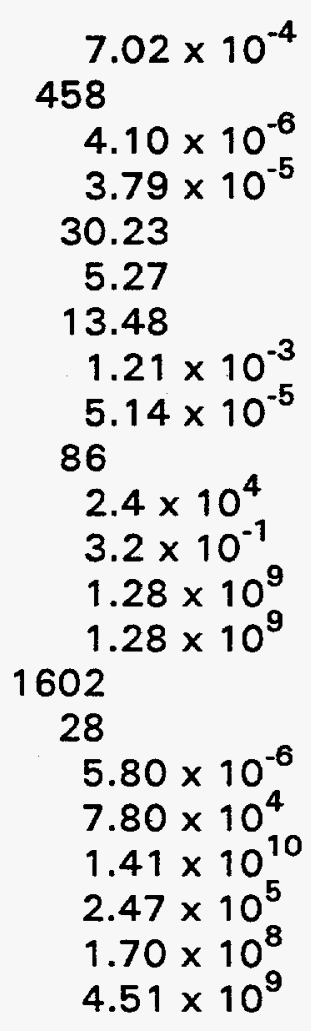

0.43

Total Airborne Radioparticulate
Emissions
$9.22 \times 10^{-6}$

$\mathrm{aCi} / \mathrm{yr}=$ curies per year; $1 \mathrm{Ci} / \mathrm{yr}=3.7 \times 10^{10}$ becquerels per year.

$b_{g} / y r=$ grams per year. 


\subsubsection{Atmospheric Radon}

Radon sources at the GJPO include the calibration test pits (for calibrating geophysical tools) and the radon calibration chambers (for calibrating portable radon-measuring devices) in Building 32. The combined radon-emission source strength is 0.52 curie (Ci) per year, which is accounted for in the off-site dose assessment modeling (Section 4.3).

\subsection{Environmental Sampling for Radioactivity}

Monitoring programs for surface water and groundwater were conducted at the GJPO facility during 1995.

Radiological analytes were measured once in surface water and five times in groundwater on and near the facility during five sampling events. Analytes measured were gross alpha, radium-226, radium-228, thorium-230, thorium-232, uranium-234, uranium-235, and uranium-238 (see Section 3.2.7, Section 6.0, and Tables A-2 through A-7 in Appendix A).

\subsection{Off-Site Dose Modeling}

Off-site dose modeling was conducted at the GJPO during 1995 to evaluate compliance with NESHAP, Subpart H, and DOE Order 5400.5. Both regulations establish a "maximally exposed individual" dose limit of $10 \mathrm{mrem} / \mathrm{yr}$ for exposure to airborne radioparticulate emissions (excluding radon) from DOE facilities. DOE Order 5400.5 also requires calculation of a collective population dose (dose to residents within an 80-kilometer radius of the facility), which includes a radon source term. Dose modeling was performed with the CAP88PC model. Meteorological data were collected with an on-site weather station, and population data were obtained from the 1990 U.S. Bureau of the Census. Dose modeling results are provided in Table 6.

Calculation of the total effective dose equivalent (EDE) to the maximally exposed offsite individual ( 600 meters west-northwest of the GJPO facility) resulted in a value of $5.19 \times 10^{-5} \mathrm{mrem} / \mathrm{yr}\left(5.19 \times 10^{-7}\right.$ millisievert per year), which is well below the DOE and EPA standard of $10 \mathrm{mrem} / \mathrm{yr}$. This value was calculated by combining emission-rate source terms from the two point sources on the facility (Analytical Laboratory and Baghouse) and entering those values into the dose assessment model CAP88PC. Because of the close proximity of both sources, the source terms were combined and treated as a single release point. 
Table 6. Effective Dose Equivalents Attributable to Radiological Emissions From the GJPO Facility During 1995

\begin{tabular}{lcc}
\hline & Standard & EDE \\
\hline $\begin{array}{l}\text { EDE from Airborne } \\
\text { Radioparticulates }\end{array}$ & $10 \mathrm{mrem} / \mathrm{yr}^{\mathrm{a}}$ & $5.19 \times 10^{-5} \mathrm{mrem} / \mathrm{yr}^{\mathrm{b}}$ \\
$\begin{array}{l}\text { Total EDE to the Public } \\
\begin{array}{l}\text { Collective Population Dose } \\
\text { (including radion) }\end{array}\end{array}$ & $100 \mathrm{mrem} / \mathrm{yr}^{\mathrm{a}}$ & $9.11 \times 10^{-3} \mathrm{mrem} / \mathrm{yr}^{\mathrm{b}}$ \\
\hline
\end{tabular}

aDOE and EPA standard (40 CFR 61.92), airborne emissions only (excludes radon).

$\mathrm{b}_{1} \mathrm{mrem} / \mathrm{yr}=0.01$ millisievert per year.

cSources of radiation were radon and air particulates.

dPopulation within $80 \mathrm{~km}$ of the facility is 117,557 .

$e_{1}$ person-rem $/ y r=0.01$ person-sievert per year.

Total EDE to the maximally exposed individual was calculated by summing the doses from radioparticulates and radon. The resulting total EDE was $9.11 \times 10^{-3} \mathrm{mrem} / \mathrm{yr}$, which is well below the DOE standard of $100 \mathrm{mrem} / \mathrm{yr}$.

In accordance with DOE Order 5400.5 , a collective population dose (including radon) was calculated at 0.10 person-rem/yr (0.001 millisievert per year). Source terms for this modeling were derived by summing the radioparticulate emissions (Table 5) and the radon source term of $0.52 \mathrm{Ci} / \mathrm{yr}$. Population centers contained in the assessment area included Cedaredge, Clifton, Colbran, DeBeque, Delta, Fruita, Gateway, Grand Junction, Mesa, Olathe, Palisade, and Whitewater. 


\subsection{Environmental Nonradiological Program Information}

\subsection{Nonradiological Effluent Data}

Nonradiological effluent sources at the GJPO facility consist of liquid effluent in the sewer system and air emissions from the Analytical Laboratory. During 1995, sewereffluent constituent concentrations were below the threshold limits established in the city of Grand Junction's industrial pretreatment permit.

An air emission permit for the Analytical Laboratory was granted final approval in January 1994. As a condition of the permit, emissions could not exceed 20-percent opacity; on the basis of process knowledge and historical observations, compliance with the opacity requirement was achieved in 1995.

In addition to the opacity requirement, the permit obtained for the Analytical Laboratory established limits on the quantity of chemicals that could be used annually. The inventory of hazardous and nonhazardous chemicals maintained by the laboratory showed that no limits were exceeded in 1995 :

\subsection{Environmental Sampling for Nonradiological Pollution}

In addition to effluent sampling, environmental sampling of surface water and groundwater for nonradiological pollutants was conducted on and near the GJPO facility. Section 3.2.7 and Section 6.0 provide descriptions of the surface-water and groundwater sampling programs, respectively, as well as comparisons of measured constituent levels with State and/or Federal water quality standards. 


\subsection{Groundwater Monitoring and Protection Program}

\subsection{Hydrogeology}

Two hydrogeologic units are of importance at the GJPO facility: (1) the unconsolidated alluvial aquifer along the Gunnison River and (2) the underlying Morrison Formation aquitard. These two units and the Gunnison River influence groundwater flow and discharge into the river.

The alluvial aquifer underlying the GJPO facility occupies about 25.0 hectares (61.7 acres) of the Gunnison River floodplain; its thickness ranges from 6 to 21 meters ( 20 to 70 feet) but averages between 6 and 8 meters ( 20 and $25 \mathrm{feet}$ ). Bounded on the west and north by the river and on the east by the shales and sandstones of the Morrison Formation, the aquifer is open to the south where the alluvium continues along the east boundary of the river. Aquifer pump tests show the hydraulic conductivity of the alluvium to be approximately 9 meters ( 30 feet) per day and the specific yield to be on the order of 0.05 . Currently, the alluvial groundwater is not used for any purpose.

The alluvial aquifer consists of two facies: (1) a poorly sorted, unconsolidated basal gravel unit with a silt and sand matrix and (2) an overlying unit of silty sand (Figure 7). Drill-hole logs from 1984 well installations indicate that both units are laterally continuous throughout the GJPO site.

Field observations suggest that a simple depositional model is adequate to represent the alluvial unit. The basal unit was deposited as the Gunnison River migrated from the east to its present position. During this migration, older alluvial sediments to the west were eroded, and a new layer of sediment was left behind. This deposition resulted in a continuous layer of gravel, sand, and silt. Periodic flood events deposited sand and silt on top of the gravel to produce the alluvial stratigraphy shown in Figure 7. Such a depositional model is similar to the alluvial-floodplain facies model of Allen (1970); the primary difference between the two is that the alluvium at the GJPO facility was deposited in a laterally more restricted and much higher energy environment. The result is a thicker and more consistent basal gravel unit.

The upgradient groundwater (southeast of the facility) tends to exhibit water quality characteristics similar to those of the Gunnison River, although major ion concentrations increase slightly as the groundwater-residence time increases. Before uranium mill tailings were removed from the facility, groundwater flowing beneath the facility became contaminated with the leached products of uranium mill tailings-uranium, arsenic, radium, selenium, and molybdenum. Only uranium and molybdenum, however, were mobile enough to migrate throughout the downgradient portion of the aquifer. 


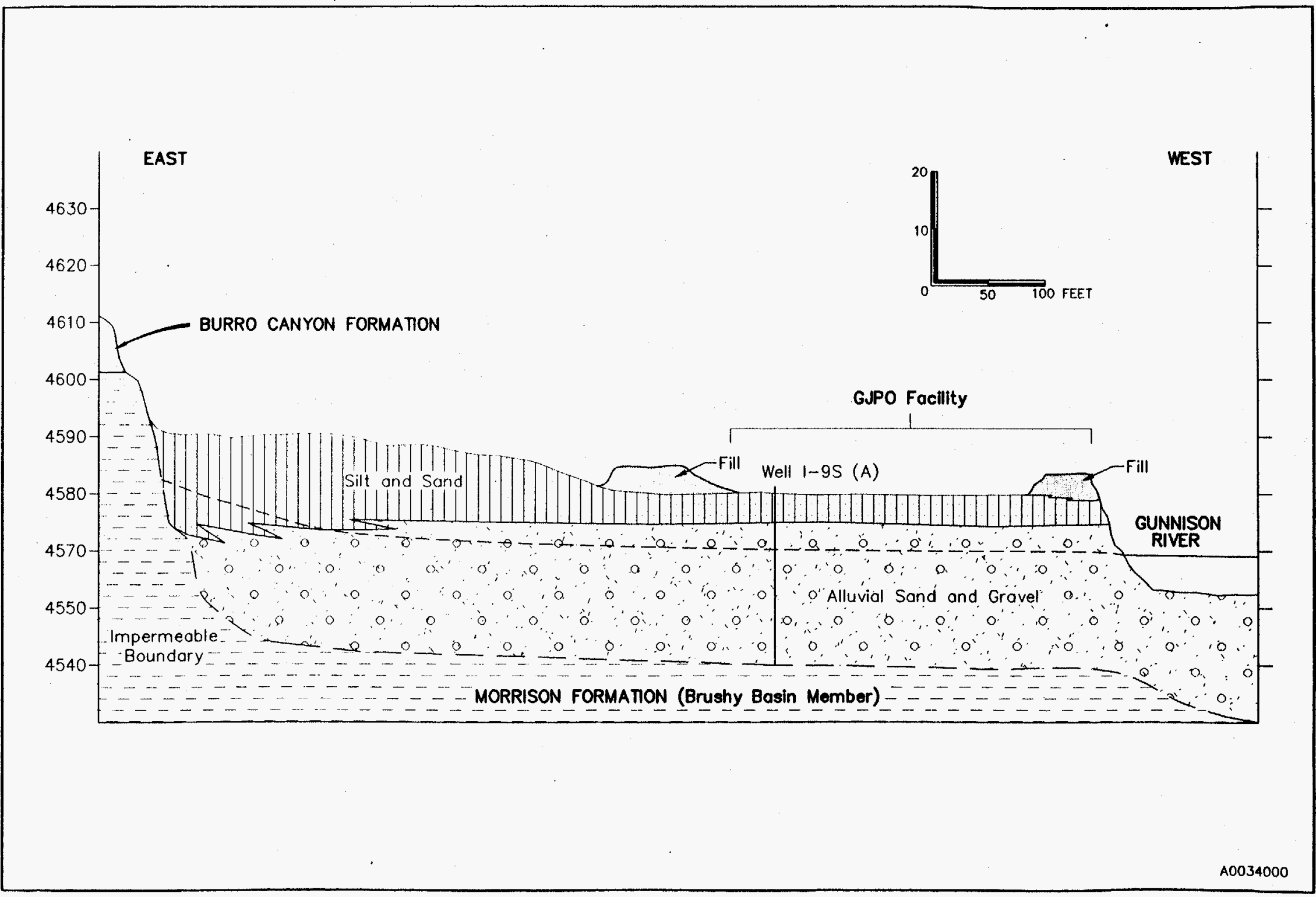

Figure 7. Typical Geological Cross Section of the Alluvial Aquifer at the GJPO Facility 
Underlying the alluvial aquifer at the GJPO facility is the Morrison Formation, that, in the Grand Junction area, consists of the Brushy Basin and Salt Wash Members. The formation is composed primarily of red, green, and gray shale, although minor lenticular sandstones are present in the upper Brushy Basin Member, and increasing sandstone facies occur in the Salt Wash Member. The Morrison Formation serves as an aquitard beneath the facility, inhibiting downward groundwater flow and preventing communication between the overlying alluvial aquifer and the underlying Entrada Sandstone aquifer.

Regionally, the upper Brushy Basin Member is approximately 104 meters (340 feet) thick; however, about 12 meters ( 40 feet) of this unit has been eroded from the GJPO facility site by the Gunnison River. Core samples from the facility show the Brushy Basin Member to contain mudstone (36 percent), siltstone (28 percent), shale (25 percent), and sandstone lenses (11 percent); Figure 8 presents a typical stratigraphic column at the GJPO facility. Lohman (1965) reported that no known wells have been developed in the sandstones of the Brushy Basin Member, although some of the sandstone lenses bear small amounts of water.

At the base of the Brushy Basin Member is a conglomeratic sandstone that grades laterally into shale. The underlying Salt Wash Member is approximately 94 meters (310 feet) thick and contains lenticular sandstone units that produce minor amounts of water. Transmissivities measured in two producing wells in the Salt Wash Member range in value from 0.44 to 0.58 square meter ( 4.8 to 6.28 square feet) per day (Lohman 1965).

At the GJPO facility, the Gunnison River incises only the upper part of the Brushy Basin Member. Brushy Basin shales are exposed along the valley margins and underlie the alluvium. This framework results in free-flowing groundwater in the alluvial aquifer because Brushy Basin shales act as a relatively impermeable boundary beneath the aquifer and along the valley margins.

Recharge of the alluvial aquifer occurs mainly through fluctuations in the Gunnison River and, to a much lesser extent, precipitation. During normal flows of the Gunnison River, groundwater enters the alluvial aquifer from the river along the southern perimeter of the GJPO facility and flows to the north. Groundwater is discharged into the river along the north and west boundaries of the facility. During periods of high river runoff, Gunnison River water recharges the alluvial aquifer and groundwater flow is toward the middle of the aquifer. 


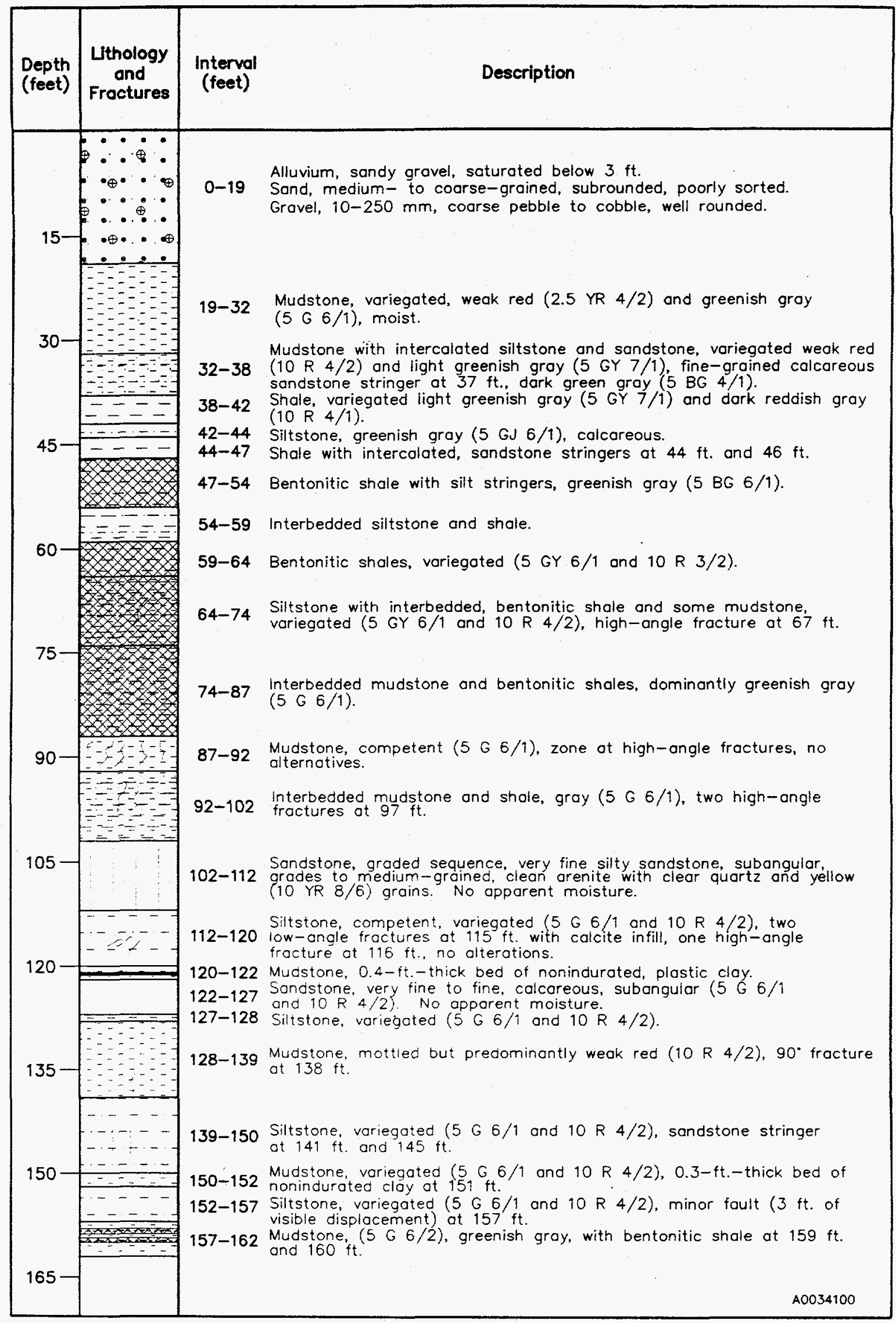

Figure 8. Typical Stratigraphic Column at the GJPO Facility (compiled from well GJ87-18) 


\subsection{Groundwater Monitoring Program}

The objectives of the groundwater monitoring program at the GJPO are (1) to determine the baseline water quality and quantity conditions of the shallow alluvial aquifer underlying the site, (2) to characterize the type and extent of the contaminant plume in the aquifer, (3) to verify compliance with Federal and State groundwater quality standards, and (4) to detect changes in water quality resulting from remedial action at the site. Past monitoring programs and characterization studies have clearly defined baseline conditions and characterized contaminants present in the groundwater; therefore, monitoring in 1995 focused on the latter two objectives.

Analytical results were compared with Federal standards promulgated by UMTRCA (40 CFR 192.12) and State standards promulgated by the Colorado Water Quality Control Act. The numeric standards applicable to the GJPO site are listed in Table 7.

NOTE: Table 7 combines Federal and State standards for comparison purposes; the more stringent standard is listed if a difference exists.

In 1995, groundwater monitoring at the GJPO involved two separate sampling schemes implemented by Rust and Oak Ridge National Laboratory (ORNL). Rust continued groundwater sampling under a long-term monitoring strategy that was designed to verify the completion of passive remediation of the alluvial aquifer in the 50- to 80-year timeframe predicted in the Record of Decision. This strategy involves sampling 12 monitoring wells every 9 months. This schedule allows compliance with groundwater standards to be assessed annually and allows for monitoring of seasonal fluctuations in contaminant concentrations over a 3-year period. The groundwater monitoring program is detailed in the Environmental Monitoring Plan (DOE 1995e).

Groundwater monitoring also was conducted by ORNL as part of an ongoing independent verification of GJPORAP. Verification involves an independent analysis of the GJPO groundwater monitoring program and examination of the passive remediation of the alluvial aquifer. Verification will be accomplished by independent groundwater sampling and analysis and by developing a new groundwater transport model to predict cleanup of the alluvial aquifer and discharges of alluvial groundwater into the Gunnison River. A 2-year intensive study commenced in 1995 with quarterly groundwater sampling. Independent verification activities are detailed in the Addendum to the Work Plan for Independent Verification of the Grand Junction Projects Office Remedial Action Project (ORNL 1994).

Five groundwater sampling events at the GJPO were conducted in 1995; one sampling event was conducted by Rust and four were conducted by ORNL. Monitoring wells sampled during each event and the constituents analyzed are summarized in Table 8. Two of the sampled wells (GJ84-09 and GJ84-10) are located upgradient of formerly contaminated areas and provide background water quality data. The remaining wells are located in or downgradient of formerly contaminated areas of the facility and represent on-site and downgradient conditions. Well locations sampled in 1995 are shown in Figure 9. 
Table 7. Comparison of Federal and State of Colorado Groundwater Quality Standards with 1995 and Historical Maximum Concentrations in the Alluvial Aquifera,b

\begin{tabular}{|c|c|c|c|c|c|c|c|c|}
\hline \multirow{2}{*}{ Constituent } & \multicolumn{2}{|c|}{$\begin{array}{l}\text { Federal/State } \\
\text { Standard }\end{array}$} & \multicolumn{3}{|c|}{1995 Kaximunc,d } & \multicolumn{3}{|c|}{ Historical Maximumd,e } \\
\hline & & & $\begin{array}{l}\text { Up- } \\
\text { Gradient }\end{array}$ & $\begin{array}{l}\text { On } \\
\text { Site }\end{array}$ & $\begin{array}{c}\text { Down- } \\
\text { Gradient }\end{array}$ & $\begin{array}{c}\text { Up- } \\
\text { Gradient }\end{array}$ & $\begin{array}{l}\text { On- } \\
\text { Site }\end{array}$ & $\begin{array}{l}\text { Down- } \\
\text { Gradient }\end{array}$ \\
\hline \multicolumn{9}{|l|}{ Comion Ions } \\
\hline $\begin{array}{l}\text { Nitrate (as N) } \\
\text { Total Dissolved } \\
\text { Sol ids } 9\end{array}$ & $\begin{array}{l}10.0 \\
2338\end{array}$ & $\mathrm{mg} / \mathrm{L}$ & 2060 & $\begin{array}{l}25.07 \\
4910\end{array}$ & $\begin{array}{l}33.88 \\
2610\end{array}$ & $2180^{1.58}$ & $\begin{array}{c}69.57 \\
10200\end{array}$ & $8620^{3.61}$ \\
\hline \multicolumn{9}{|l|}{ Metals } \\
\hline $\begin{array}{l}\text { Arsenic } \\
\text { Barium } \\
\text { Cadmiun } \\
\text { Chromium } \\
\text { Lead } \\
\text { Mercury } \\
\text { Molybdenum } \\
\text { Selenium } \\
\text { Silver }\end{array}$ & $\begin{array}{l}0.05 \\
1.0 \\
0.010 \\
0.05 \\
0.05 \\
0.002 \\
0.1 \\
0.01 \\
0.05\end{array}$ & $\begin{array}{l}\mathrm{mg} / \mathrm{L} \\
\mathrm{mg} / \mathrm{L} \\
\mathrm{mg} / \mathrm{L} \\
\mathrm{mg} / \mathrm{L} \\
\mathrm{mg} / \mathrm{L} \\
\mathrm{mg} / \mathrm{L} \\
\mathrm{mg} / \mathrm{L} \\
\mathrm{mg} / \mathrm{L} \\
\mathrm{mg} / \mathrm{L}\end{array}$ & $\begin{array}{l}<0.003 \\
<0.0172 \\
<0.001 \\
<0.004 \\
<0.001 \\
\cdots \\
<0.017 \\
<0.002 \\
\cdots\end{array}$ & $\begin{array}{l}0.35 \\
0.079 \\
<0.005 \\
<0.004 \\
-0.0019 \\
0.00015 \\
0.64 \\
0.089 \\
0.006\end{array}$ & $\begin{array}{l}0.011 \\
0.038 \\
<0.005 \\
<0.004 \\
<0.02 \\
0.00014 \\
0.24 \\
0.073 \\
0.0056\end{array}$ & $\begin{array}{l}0.01 \\
<0.0187 \\
<0.002 \\
0.010 \\
<0.01 \\
0.0002 \\
0.023 \\
-0.0025 \\
<0.01\end{array}$ & $\begin{array}{l}0.68 \\
0.4 \\
0.055 \\
0.039 \\
0.0571 \\
0.0002 \\
19 . \\
0.685 \\
<0.01\end{array}$ & $\begin{array}{l}-0.031 \\
-0.0316 \\
<0.002 \\
0.112 \\
\sim 0.0015 \\
0.0002 \\
0.413 \\
0.05 \\
<0.01\end{array}$ \\
\hline \multicolumn{9}{|l|}{ Radiological } \\
\hline $\begin{array}{l}\text { Gross Alpha (excluding } \\
\text { radon and uranium) }\end{array}$ & 15 & $\mathrm{PCi} / \mathrm{L}$ & $<69$ & 109.8 & 23.23 & 71.02 & 1073.14 & 620.52 \\
\hline $\begin{array}{l}\text { Radium-226, }-228 \\
\text { Thor ium-230, }-232 \\
\text { Uranium-234, }-238 i\end{array}$ & $\begin{array}{l}5.0 \\
60.0\end{array}$ & 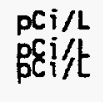 & $\begin{array}{l}<3 \\
<10.87\end{array}$ & $\begin{array}{r}2.41 \\
132.94\end{array}$ & $\begin{array}{r}2.11 \\
592.74\end{array}$ & $2 \mathfrak{1}:\}^{j}$ & $\begin{array}{r}36 \\
5998\end{array}$ & 999.3 \\
\hline \multicolumn{9}{|l|}{ Herbicides } \\
\hline $\begin{array}{l}2,4,5-T P(\text { Silvex }) \\
2,4-0\end{array}$ & $\begin{array}{r}10 \\
100\end{array}$ & $\underset{\mu g / L}{\mu g / L}$ & $\begin{array}{l}-\cdots \\
\cdots\end{array}$ & - & 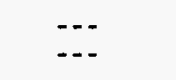 & $\begin{array}{l}<0.2 \\
<1.2\end{array}$ & $\begin{array}{l}<10 \\
<20\end{array}$ & $\begin{array}{l}<0.2 \\
<1.2\end{array}$ \\
\hline \multicolumn{9}{|l|}{ Pesticides \& PCBs } \\
\hline $\begin{array}{l}4,4^{\prime}-\text { DDT } \\
\text { Aldrin } \\
\text { Dieldrin } \\
\text { Endrin } \\
\text { Heptachlor } \\
\text { Heptachlor Epoxide } \\
\text { Methoxychlor } \\
\text { PCBsk } \\
\text { Toxaphene } \\
\text { gamma-BHC (Lindane) }\end{array}$ & $\begin{array}{c}0.1 \\
0.1 \\
0.1 \\
0.2 \\
0.1 \\
0.1 \\
100 \\
0.5 \\
5 \\
4\end{array}$ & $\begin{array}{l}\mu g / L \\
\mu g / L \\
\mu g / L \\
\mu g / L \\
\mu g / L \\
\mu g / L \\
\mu g / L \\
\mu g / L \\
\mu g / L \\
\mu g / L\end{array}$ & $\begin{array}{l}--. \\
-\ldots \\
\cdots- \\
-- \\
-- \\
-- \\
\cdots \\
\cdots \\
-- \\
\cdots\end{array}$ & $\begin{array}{l}<0.1 \\
<0.05 \\
<0.1 \\
<0.1 \\
<0.05 \\
<0.05 \\
<0.5 \\
<1 \\
<1 \\
<0.05\end{array}$ & $\begin{array}{l}<0.1 \\
<0.05 \\
<0.1 \\
<0.1 \\
<0.05 \\
<0.05 \\
<0.5 \\
<1 \\
<1 \\
<0.05\end{array}$ & $\begin{array}{l}<0.1 \\
<0.05 \\
<0.1 \\
<0.12 \\
<0.05 \\
<0.05 \\
<0.5 \\
<2 \\
<5 \\
<0.05\end{array}$ & $\begin{array}{l}<0.1 \\
<0.052 \\
<0.1 \\
<0.12 \\
<0.052 \\
<0.052 \\
<5 \\
<2.1 \\
<48 \\
<0.8\end{array}$ & $\begin{array}{l}<0.1 \\
<0.05 \\
<0.1 \\
<0.1 \\
<0.05 \\
<0.05 \\
<0.5 \\
<2 \\
<5 \\
<0.05\end{array}$ \\
\hline
\end{tabular}

\footnotetext{
a Federal standards from the Uranium Mill Tailings Radiation Control Act, revised in 1986.

bDPHE Water Quality Control Division, Basic Standards for Ground Water. "Potentially Usable Quality" classification revised 10/17/91. Only the standards applicable to the GJPO facility are listed.

$c_{A} \ldots . . .1$ indicates no data were available; a "<" indicates that the maximum concentration was below detection limit (number shown is detection limit); a " il indicates an approximate value (the value was outside the limits for which the instrument was calibrated).

The units are indicated in the "Federal/state Standard" column.

EBased on maximum concentrations observed from 1984 through 1994.

$f_{\mathrm{Nitrate}}$ (as $\mathrm{N}$ ) was derived for measured nitrate using the conversion: nitrate (as $N$ ) $=\mathrm{NO}_{3}+4.427$.

9This is a site-specific standard calculated as background times 1.25 . The background value is based on the June 1995 sampl ing event.

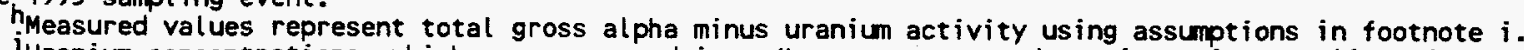

iUranium concentrations, which were measured in $\mathrm{mg} / \mathrm{L}$, were converted to picocuries per liter for comparison purposes. The conversion assumes equilibrium and an activity of $0.666 \mathrm{pCi} / \mu \mathrm{g}$.

Extreme-values testing of uranium results from samples collected in 1985 and 1989 indicated that two values ( $1998 \mathrm{PCi} / \mathrm{L}$ and $83.25 \mathrm{pCi} / \mathrm{L}$ ) were out $\mathrm{K}$ ers; these values from upgradient wells were not included in this table.

RCBs include Aroclor 1016, 1221, 1232, 1242, 1248, 1254, and 1260.
} 


\section{Table 7 (continued). Comparison of Federal and State of Colorado Groundwater Quality Standards with 1995 and Historical Maximum Concentrations in the Alluvial Aquifer a,b}

\begin{tabular}{|c|c|c|c|c|c|c|c|c|}
\hline \multirow{2}{*}{ Const i tuent } & \multirow{2}{*}{\multicolumn{2}{|c|}{$\begin{array}{l}\text { Federal/State } \\
\text { Standard }\end{array}$}} & \multicolumn{3}{|c|}{1995 Naxime,d } & \multicolumn{3}{|c|}{ Historical Kaxiefd,e } \\
\hline & & & $\begin{array}{l}\text { Up- } \\
\text { Gradient }\end{array}$ & $\begin{array}{l}\text { On } \\
\text { site }\end{array}$ & $\begin{array}{c}\text { Down- } \\
\text { Gradient }\end{array}$ & $\begin{array}{c}\text { Up- } \\
\text { Gradient }\end{array}$ & $\begin{array}{c}\mathrm{Cn}^{-} \\
\text {site }\end{array}$ & $\begin{array}{l}\text { Down- } \\
\text { Gradient }\end{array}$ \\
\hline \multicolumn{9}{|l|}{ Senivolatile Organics } \\
\hline $\begin{array}{l}\text { 1,2-Dichlorobenzene } \\
\text { 1,3-Dichlorobenzene } \\
\text { 1,4-Dichlorobenzene } \\
\text { 2,4,5-Trichlorophenol } \\
\text { 2,4,6-Trichlorophenol } \\
\text { 2,4-Dichlorophenol } \\
\text { Hexachlorobenzene } \\
\text { Hexachlorobutadiene } \\
\text { Hexachlorocyclopenta- } \\
\text { diene }\end{array}$ & $\begin{array}{l}620 \\
620 \\
75 \\
700 \\
10 \\
21 \\
10 \\
14 \\
49\end{array}$ & $\begin{array}{l}\mu \mathrm{g} / \mathrm{L} \\
\mu \mathrm{g} / \mathrm{L} \\
\mu \mathrm{g} / \mathrm{L} \\
\mu \mathrm{g} / \mathrm{L} \\
\mu \mathrm{g} / \mathrm{L} \\
\mu \mathrm{g} / \mathrm{L} \\
\mu \mathrm{g} / \mathrm{L} \\
\mu \mathrm{g} / \mathrm{L} \\
\mu \mathrm{g} / \mathrm{L}\end{array}$ & $\begin{array}{l}\cdots \\
\cdots \\
\cdots \\
\cdots \\
\cdots \\
\cdots \\
\cdots \\
\cdots \\
\cdots\end{array}$ & $\begin{array}{l}<11 \\
<11 \\
2 \\
<28 \\
<11 \\
<11 \\
<11 \\
<11 \\
<11\end{array}$ & $\begin{array}{l}<11 \\
<11 \\
<11 \\
<28 \\
<11 \\
<11 \\
<11 \\
<11 \\
<11\end{array}$ & $\begin{array}{l}<10 \\
<10 \\
<10 \\
<50 \\
<10 \\
<10 \\
<10 \\
<10 \\
<10\end{array}$ & $\begin{array}{l}<10 \\
<10 \\
-1 \\
<50 \\
<10 \\
<10 \\
<10 \\
<10 \\
<10\end{array}$ & $\begin{array}{l}<10 \\
<10 \\
<10 \\
<50 \\
<10 \\
<10 \\
<10 \\
<10 \\
<10\end{array}$ \\
\hline $\begin{array}{l}\text { I sophorone } \\
\text { Ni trobenzene } \\
\text { Pentachlorophenol } \\
\text { bis(2-Chloroethyl) } \\
\text { Ether }\end{array}$ & $\begin{array}{r}1050 \\
10 \\
200 \\
10\end{array}$ & $\begin{array}{l}\mu \mathrm{g} / \mathrm{L} \\
\mu \mathrm{g} / \mathrm{L} \\
\mu \mathrm{g} / \mathrm{L} \\
\mu \mathrm{g} / \mathrm{L}\end{array}$ & $\begin{array}{l}\cdots \\
\cdots \\
\cdots- \\
\cdots\end{array}$ & $\begin{array}{l}<11 \\
<11 \\
<28 \\
<11\end{array}$ & $\begin{array}{l}<11 \\
<11 \\
<28 \\
<11\end{array}$ & $\begin{array}{l}<10 \\
<10 \\
<50 \\
<10\end{array}$ & $\begin{array}{l}<10 \\
<10 \\
<50 \\
<10\end{array}$ & $\begin{array}{l}<10 \\
<10 \\
<50 \\
<10\end{array}$ \\
\hline \multicolumn{9}{|l|}{ Volatile Organics } \\
\hline $\begin{array}{l}\text { 1,1,1-Trichloroethane } \\
1,1,2-\text { Trichloroethane } \\
1,1-\text { Dichloroethene } \\
1,2-0 \text { ichloroethane } \\
1,2-D \text { ichloropropane } \\
\text { Benzene } \\
\text { Carbon Tetrachloride } \\
\text { Chlorobenzene } \\
\text { Ethyl benzene } \\
\text { Tetrachloroethene } \\
\text { Toluene } \\
\text { Trichloroethene } \\
\text { Trihalomethanes } \\
\text { Vinyl Chloride } \\
\text { cis-1,2-Dichloroethene } \\
\text { trans-1,2- } \\
\text { Dichloroethene }\end{array}$ & $\begin{array}{r}200 \\
28 \\
7 \\
5 \\
6 \\
5 \\
5 \\
300 \\
680 \\
10 \\
2420 \\
5 \\
100 \\
2 \\
70 \\
70\end{array}$ & $\begin{array}{l}\mu g / L \\
\mu g / L \\
\mu g / L \\
\mu g / L \\
\mu g / L \\
\mu g / L \\
\mu g / L \\
\mu g / L \\
\mu g / L \\
\mu g / L \\
\mu g / L \\
\mu g / L \\
\mu g / L \\
\mu g / L \\
\mu g / L \\
\mu g / L\end{array}$ & 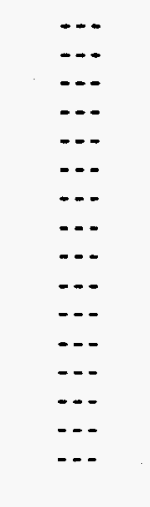 & $\begin{array}{l}<5 \\
<5 \\
<5 \\
<5 \\
<5 \\
<5 \\
<5 \\
<5 \\
<5 \\
<5 \\
<5 \\
<5 \\
<5 \\
<5 \\
<10 \\
<5 \\
<5\end{array}$ & $\begin{array}{l}<5 \\
<5 \\
<5 \\
<5 \\
<5 \\
<5 \\
<5 \\
<5 \\
<5 \\
<5 \\
<5 \\
<5 \\
<5 \\
<10 \\
<5 \\
<5\end{array}$ & $\begin{array}{l}<5 \\
<5 \\
<5 \\
<5 \\
<5 \\
<5 \\
<5 \\
<5 \\
<5 \\
<5 \\
<5 \\
<5 \\
<5 \\
<10 \\
<5 \\
<5\end{array}$ & $\begin{array}{l}<5 \\
<5 \\
<5 \\
<5 \\
<5 \\
<5 \\
<5 \\
<5 \\
<5 \\
<5 \\
<5 \\
<5 \\
<5 \\
<5 \\
<10 \\
<5 \\
<5\end{array}$ & $\begin{array}{l}<5 \\
<5 \\
<5 \\
<5 \\
<5 \\
<5 \\
<5 \\
<5 \\
<5 \\
<5 \\
<5 \\
<5 \\
<5 \\
<5 \\
<10 \\
<5 \\
<5\end{array}$ \\
\hline
\end{tabular}

\footnotetext{
a Federal standards from the Uranium Mill Tailings Radiation Control Act, revised in 1986.

bCDPHE Water Quality Control Division, Basic Standards for Ground Water. "Potentially Usable Quality" classification revised 10/17/91. Only the standards applicable to the GJPO facility are listed.

$C_{A}$ "..." indicates no data were available; a "<" indicates that the maximum concentration was below detection limits (number shown is detection limit); a " " indicates an approximate value (the value was outside the limits for which the instrument was cal ibrated).

The units are indicated in the "Federal/State Standard" column.

e Based on maximum concentrations observed from 1984 through 1994.
} 
Table 8. 1995 GJPO Groundwater Sampling and Analytical Design Schedule

\begin{tabular}{lll} 
Month & Contractor & Wells Sampled \\
\hline & & \\
January & ORNL & 11-1S, 14-6NA, GJ84-04, \\
& GJ84-05, GJ94-01, GJ94-02 \\
& GJ94-03, GJ94-04, GJ94-05, \\
& GJ94-06, GJ94-07, GJ94-08, \\
& GJ94-09, and P-6
\end{tabular}

Analytes Measured $\begin{array}{ll}\text { April } & \text { ORNL } \\ & \begin{array}{l}\text { GJ94-02, GJ94-03, GJ94-04, } \\ \text { GJ94-05, GJ94-07, GJ94-08, } \\ \text { and GJ94-09 }\end{array}\end{array}$

$\mathrm{Ag}, \mathrm{Al}, \mathrm{As}, \mathrm{Ba}, \mathrm{Be}, \mathrm{Ca}, \mathrm{Cd}, \mathrm{Co}, \mathrm{Cr}, \mathrm{Cu}$, $\mathrm{Fe}, \mathrm{Hg}, \mathrm{K}, \mathrm{Mg}, \mathrm{Mn}, \mathrm{Mo}, \mathrm{Na}, \mathrm{Ni}, \mathrm{Pb}, \mathrm{Sb}$, Se, Tl, U, V, and $\mathrm{Zn}$

$\begin{array}{ll}\text { June } \quad \text { Rust } & \text { GJ84-04, GJ84-09, GJ84-10 } \\ & 5-12 N A, 1-9 \text { SA, 11-1S, } \\ & 11-12 N A, 14-6 N A, 14-13 N A, \\ & 10-19 N, 8-4 S \text {, and GJ87-15 }\end{array}$

$\mathrm{Ag}, \mathrm{Al}, \mathrm{As}, \mathrm{Ba}, \mathrm{Be}, \mathrm{Ca}, \mathrm{Cd}, \mathrm{Cl}, \mathrm{Co}$, $\mathrm{Cu}, \mathrm{Fe}, \mathrm{Hg}, \mathrm{K}, \mathrm{Mg}, \mathrm{Mn}, \mathrm{Mo}, \mathrm{Na}, \mathrm{Ni}, \mathrm{NO}_{3}$, $\mathrm{Pb}, \mathrm{PO}_{4}, \mathrm{Ra}-226, \mathrm{Sb}, \mathrm{Se}, \mathrm{SO}_{4}, \mathrm{Tl}, \mathrm{U}, \mathrm{V}$, and $\mathrm{Zn}$; pesticides, semivolatile organic compounds, and volatile organic compounds 8-4S, and GJ87

11-1S, 14-6NA, GJ84-04, GJ94-01, GJ94-02, GJ94-03, GJ94-04, GJ94-05, GJ94-06, GJ94-07, and GJ94-08

11-1S, 14-6NA, GJ84-04, GJ94-01, GJ94-02, GJ94-03, GJ94-04, GJ94-05, GJ94-06, GJ94-07, GJ94-08, GJ94-09, $8-4 S$, and $P-6$
As, $\mathrm{Ba}, \mathrm{Ca}, \mathrm{Cd}, \mathrm{Cl}, \mathrm{Cr}, \mathrm{Fe}, \mathrm{K}, \mathrm{Mg}, \mathrm{Mn}$, $\mathrm{Mo}, \mathrm{Na}, \mathrm{NO}_{3}, \mathrm{~Pb}, \mathrm{Ra}-226, \mathrm{Ra}-228, \mathrm{Se}$, $\mathrm{SO}_{4}, \mathrm{Th}-230$, Th-232, U-234, U-235, U-238, gross alpha, and V; gross alpha, total dissolved solids, and total organic carbon

$\mathrm{Ag}, \mathrm{Al}, \mathrm{As}, \mathrm{B}, \mathrm{Ba}, \mathrm{Be}, \mathrm{Ca}, \mathrm{Cd}, \mathrm{Co}, \mathrm{Cr}$, $\mathrm{Cu}, \mathrm{Fe}, \mathrm{Hg}, \mathrm{K}, \mathrm{Mg}, \mathrm{Mn}, \mathrm{Mo}, \mathrm{Na}, \mathrm{Ni}, \mathrm{Pb}$, $\mathrm{Sb}, \mathrm{Se}, \mathrm{Si}, \mathrm{Tl}, \mathrm{U}, \mathrm{V}$, and $\mathrm{Zn}$

$\mathrm{Ag}, \mathrm{Al}, \mathrm{As}, \mathrm{B}, \mathrm{Ba}, \mathrm{Be}, \mathrm{Ca}, \mathrm{Cd}, \mathrm{Co}, \mathrm{Cr}$, $\mathrm{Cu}, \mathrm{Fe}, \mathrm{Hg}, \mathrm{K}, \mathrm{Mg}, \mathrm{Mn}, \mathrm{Mo}, \mathrm{Na}, \mathrm{Ni}, \mathrm{Pb}$, $\mathrm{Sb}, \mathrm{Se}, \mathrm{Si}, \mathrm{Tl}, \mathrm{U}, \mathrm{V}$, and $\mathrm{Zn}$ 


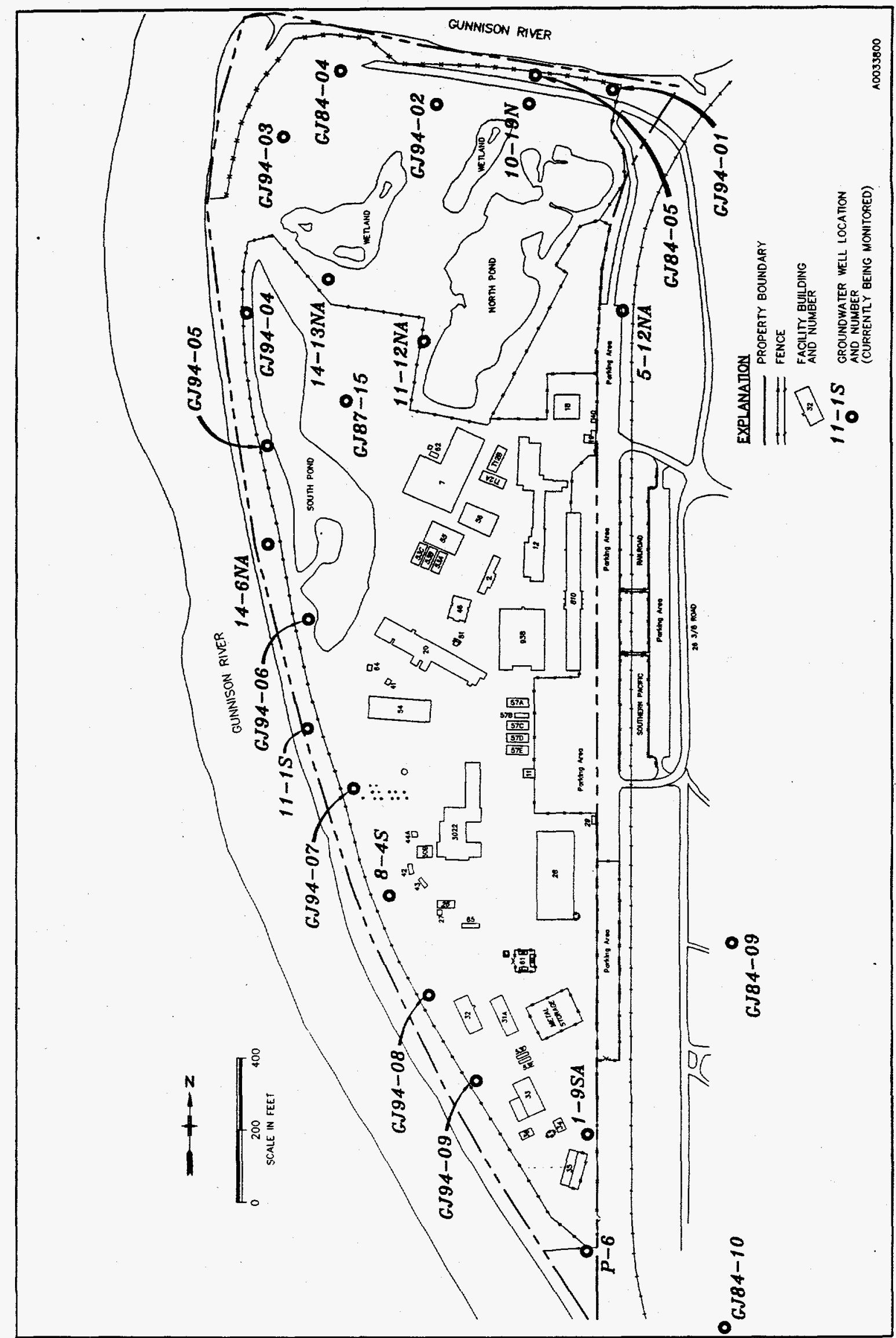


Samples were collected by Rust with dedicated stainless-steel and Teflon bladder pumps that had Teflon or Teflon-lined discharge tubing. Samples requiring filtration were filtered with an in-line $0.45-\mu \mathrm{m}$ disposable filter. Sampling procedures and protocol are described in the GJPO, GJPORAP, and MMTS Sampling and Analysis Plan for Environmental Monitoring (DOE 1995d), which incorporates the standard procedures published by EPA $(1985,1987)$ and DOE (1987).

Samples were collected by ORNL with dedicated bladder pumps, a peristaltic pump, or a submersible pump. Sampling procedures and protocol are described in the Environmental Technology Section, Procedures Manual Volume II: Health and Safety and Technical Procedures (ORNL 1993).

Analytical results of samples collected from groundwater monitoring wells are listed in Tables A-3 through A-7 in Appendix A. Table 7 lists 1995 and historical maximum analyte concentrations compared with Federal and State groundwater quality standards. Figure 10 presents maximum concentrations of groundwater analytes that exceeded Federal or State standards for each well.

Uranium contamination is widespread throughout the alluvial aquifer beneath the facility. Uranium activities above the UMTRCA standard of $30 \mathrm{pCi} / \mathrm{L}$ (approximately $0.045 \mathrm{mg} / \mathrm{L}$ ) were recorded in samples from all the alluvial wells at some time during the year, except for the two background wells (GJ84-09 and GJ84-10), GJ94-06, and for wells 1-9SA and P-6 located in the southeast (nearest-to-upgradient) portion of the facility. The highest uranium concentration, $732.6 \mathrm{pCi} / \mathrm{L}(1.1 \mathrm{mg} / \mathrm{L})$, recorded in 1995 was measured in a sample from well GJ94-02, located in the north portion of the facility. Samples from well GJ84-04 have consistently exceeded the UMTRCA uranium standard. Figure B-4a in Appendix B shows uranium concentrations in samples collected from well GJ84-04 from January 1989 to October 1995. For comparison, Figure B-4b shows background uranium concentrations in samples from well GJ84-10 for the same time period.

Molybdenum contamination also is widespread in the alluvial aquifer with the highest concentration $(0.64 \mathrm{mg} / \mathrm{L})$ occurring in a sample from well GJ94-07. Samples from 12 other wells yielded molybdenum concentrations in excess of the UMTRCA groundwater standard of $0.1 \mathrm{mg} / \mathrm{L}$ (Figure 10). Concentrations of molybdenum in samples collected from well $10-19 \mathrm{~N}$ for the past 7 years are illustrated in Figure B-5a. Background molybdenum concentrations in samples from well GJ84-10 are illustrated in Figure B-5b.

Arsenic contamination is localized in the area formerly occupied by a large tailings pile. A sample from well GJ94-05 yielded the highest arsenic concentration of $0.35 \mathrm{mg} / \mathrm{L}$. The UMTRCA groundwater standard of $0.05 \mathrm{mg} / \mathrm{L}$ also was exceeded in samples from wells 14-6NA and GJ87-15 (Figure 10). As shown in Figure B-6a, arsenic concentrations have consistently exceeded the UMTRCA standard in samples from well 14-6NA. Background arsenic concentrations in samples from well GJ84-10 are shown in Figure B-6b for comparison purposes. 


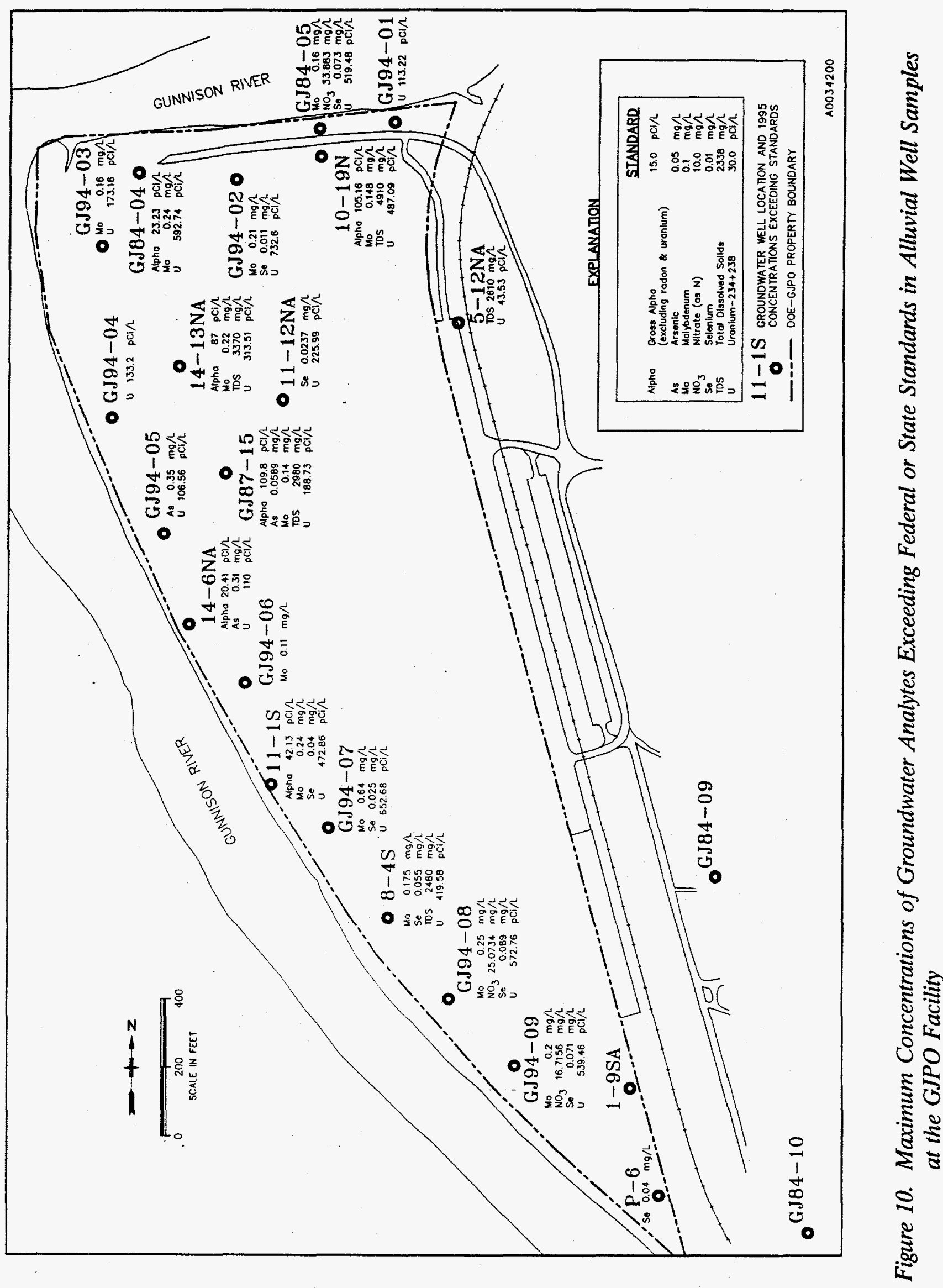


Selenium contamination appeared in samples from wells 11-1S, 11-12NA, GJ84-05, GJ94-02, GJ94-07, GJ94-08, GJ94-09, P-6, and 8-4S, which all yielded concentrations in excess of the UMTRCA groundwater standard of $0.01 \mathrm{mg} / \mathrm{L}$ (Figure 10). The highest selenium concentration, $0.089 \mathrm{mg} / \mathrm{L}$, was recorded in a sample from well GJ94-08. Selenium concentrations in samples from well GJ87-15 have been below the UMTRCA standard since open-land soil remediation was completed in 1994 (Figure B-7a). Samples from background well GJ84-10 have always contained concentrations below the standard (Figure B-7b).

Nitrate also occurred in elevated concentrations on the facility. Samples containing concentrations in excess of the UMTRCA groundwater standard of $10.0 \mathrm{mg} / \mathrm{L}$ (nitrate as N) were obtained from wells GJ84-05, GJ94-08, and GJ94-09 (Figure 10). The maximum nitrate (as nitrogen) concentration of $33.88 \mathrm{mg} / \mathrm{L}$ occurred in well GJ84-05.

TDS concentrations exceeded the aquifer-specific State standard of $2,338 \mathrm{mg} / \mathrm{L}$ (1.25 times background) in samples from wells 5-12NA, 8-4S, 10-19N, 14-13NA, and GJ87-15 (Figure 10). The highest TDS concentration recorded in $1995(4,910 \mathrm{mg} / \mathrm{L})$ occurred in a sample from well 10-19N. Samples from well 10-19N have consistently contained TDS concentrations exceeding the State standard.

The highest gross alpha activity $(109.8 \mathrm{pCi} / \mathrm{L}$, excluding radon and uranium) recorded in 1995 was measured in a sample from well GJ87-15. Gross alpha activities exceeding the State standard of $15 \mathrm{pCi} / \mathrm{L}$ also were recorded in samples from alluvial wells $10-19 \mathrm{~N}$, 11-1S, 14-6NA, 14-13NA, and GJ84-04

Note: Gross alpha measurements were compared with the standard, which excludes uranium and radon, by subtracting uranium activities from the reported gross alpha activities; the analytical process for determining gross alpha eliminates radon from the sample.

Historically, radium-226 contamination appeared to be localized in areas of buried tailings, which have now been remediated. In 1995, the State and UMTRCA radium-226 and radium-228 standard of $5 \mathrm{pCi} / \mathrm{L}$ was not exceeded in any well. Figure B-8a shows radium-226 and radium-228 concentrations over time in samples from well 8-4S. As shown in Figure B-8a, the UMTRCA radium standard has not been exceeded in samples from well 8-4S since remediation of the southwest portion of the facility was completed in 1992. Background radium-226 and radium-228 concentrations are shown in Figure B-19.

Sampling for Target Compound List (TCL) volatile organic compounds, TCL semivolatile organic compounds, and TCL pesticides and PCBs was conducted in January 1995 (Table A-8 in Appendix A). The State groundwater standards for organic compounds were not exceeded in any samples (Table 7). Generally, organic compounds were not detected or were detected in low concentrations (Table A-7). Detected TCL volatile organic compounds (acetone and 2-butanone) ranged in concentration from 2 to $8 \mu \mathrm{g} / \mathrm{L}$, and detected semivolatile organic compounds (1,4-dichlorobenzene, bis[2-ethylhexyl]phthalate, and Diethylphthalate) ranged in concentration from 1 to $3 \mu \mathrm{g} / \mathrm{L}$. These concentrations were estimated (i.e., the compounds were identified, but 
the concentrations were below the quantification limit). Because these estimated results are at the limitations of the analytical technique, the detected compounds are not considered actual groundwater contaminants. This organic compound investigation yielded results similar to an organic compound characterization conducted in 1991 and 1992.

Volatile and semivolatile organic compounds that were not TCL constituents, but that were detected, were labeled as tentatively identified compounds (Table A-7). Tentatively identified compounds were labeled as such because the laboratory instrument was not calibrated for that specific compound, which resulted in an estimated concentration. Because the estimated concentrations were less than $47 \mu \mathrm{g} / \mathrm{L}$, these compounds were not considered potential contaminants in the groundwater.

During 1995, concentrations of uranium, molybdenum, arsenic, selenium, nitrate, TDS, and gross alpha in samples from the alluvial aquifer exceeded groundwater quality standards (Figure 10). Figures C-1 through C-5 in Appendix C identify the analytes that exceeded applicable standards in samples during the 1995 sampling events. The objective of future monitoring is to verify improvement in groundwater quality and to verify passive remediation of the alluvial aquifer. Modeling of the alluvial aquifer predicts that the groundwater will be cleaned to below applicable standards within 50 to 80 years after the uranium mill tailings source is removed. Uranium mill tailings removal from open-land areas on the facility began in late 1989 and was completed in June 1994.

To date, six groundwater sampling events have been conducted since remediation of open-land areas was completed. Time-concentration plots in Appendix B, as well as a statistical study of uranium and molybdenum values from well GJ84-04, indicate aquifer cleanup is progressing. Uranium concentrations from June 1984 (preremediation) and June 1995 (postremediation) are shown in Figures 11 and 12, respectively; these figures provide a visual indication that passive remediation of the alluvial aquifer is progressing. 


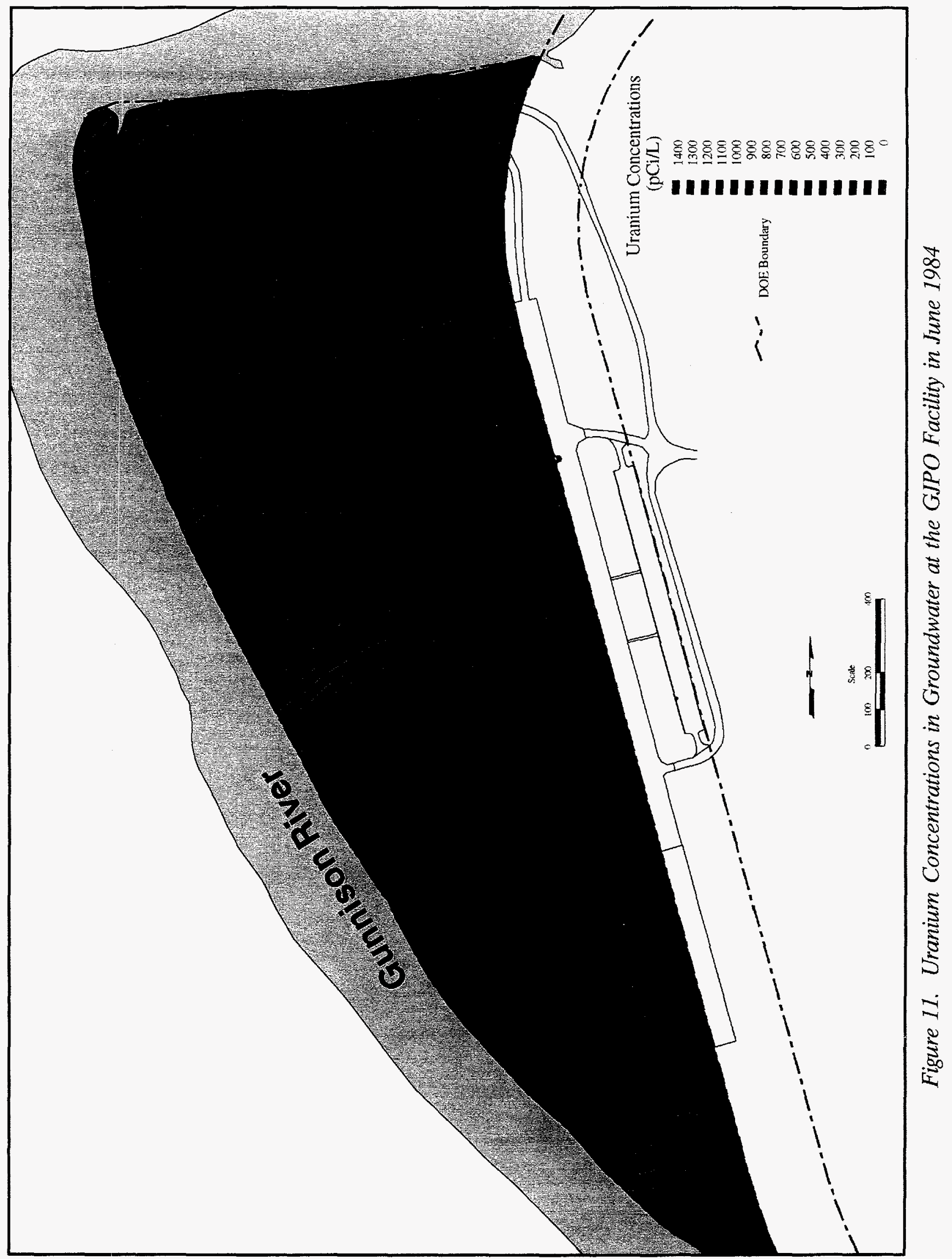




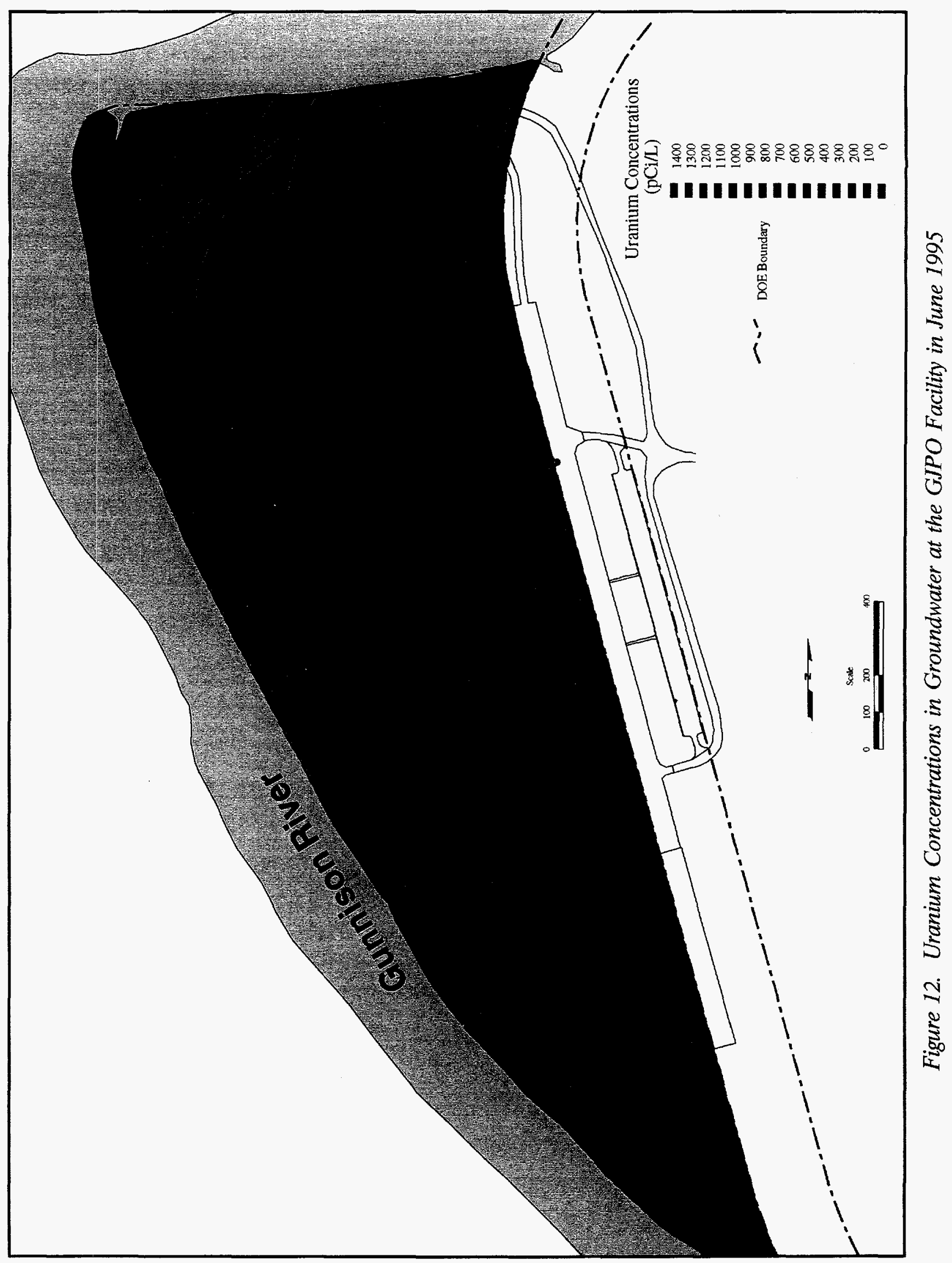

1995 GJPO Site Environmental Report Page 55

DOE/Grand Junction Projects Office May 31, 1996 


\subsection{Quality Assurance}

DOE-GJPO has a QA program administered by Rust that is designed to adopt and implement the requirements of 10 CFR 830.120, Quality Assurance Requirements and the cultural philosophy of DOE Order 5700.6C, Quality Assurance. This GJPO QA Program provides a structured approach for the application of QA principles to work performed by DOE; this program is implemented through the Quality Assurance Manual (Rust Geotech 1995e). ORNL's QA program is implemented through Requirements for Quality Control of Analytical Data for the Environmental Restoration Program (ORNL 1992).

The Quality Assurance Program Plan (QAPP) was developed for specific environmental monitoring and surveillance needs at the GJPO and is appended to the Environmental Monitoring Plan (DOE 1995e). The primary purposes of the QAPP are to ensure that environmental data are valid and traceable and that they fulfill the requirements of the QA program. In addition, the QAPP addresses organizational responsibility, QA procedures, records, and audits. . Field and laboratory quality control (QC), chain-ofcustody, performance reporting, and independent data verification are addressed by the organizations responsible for the work performed.

\subsection{Sampling}

Methodologies used for effluent monitoring and environmental sampling conducted by Rust at the GJPO are described in the Environmental Procedures Catalog (Rust Geotech 1995c) and follow Test Methods for Evaluating Solid Waste (EPA 1986). ORNL sampling procedures are detailed in the Environmental Technology Section Procedures Manual Volume II: Health and Safety and Technical Procedures (ORNL 1993). QA and QC measures are integrated into all sampling activities to ensure sample representativeness, sample accuracy, sample precision, data comparability, and data completeness. The GJPO, GJPORAP, and MMTS Sampling and Analysis Plan for Environmental Monitoring (DOE 1995d) outlines the procedures used for documentation requirements, sample collection, and sampling protocol. The procedures used to ensure that the samples are representative, comparable, precise, and complete include: collecting field duplicates, equipment blanks, and trip blanks; conducting frequent QA audits to ensure compliance with the sampling plan; and documenting and tracking sample custody with chain-of-custody procedures.

\subsection{Laboratory Analysis}

The Analytical Laboratory performs analyses in support of GJPO environmental monitoring programs and implements QA requirements through the Analytical Chemistry Laboratory Administrative Plan and Quality Control Procedures (Rust Geotech 1995a). The Analytical Laboratory's objective is to provide high-quality analytical data that adequately meet environmental monitoring program requirements. This objective is met by implementing a laboratory protocol that ensures that each sample retains its proper 
identity, that analytical results are obtained and reported correctly, and that a welldocumented sample history is maintained. QA measures address organizational responsibility, training and qualification of personnel, laboratory records, records control, laboratory QC, data acceptance, sample analysis, data recording and calculation, data deficiencies, chain of custody, procurement of services, and quality assessment. Analytical methodologies are presented in the Analytical Chemistry Laboratory Handbook of Analytical and Sample-Preparation Procedures (Rust Geotech 1995b) and Requirements for Quality Control of Analytical Data (ORNL 1990).

The Analytical Laboratory maintains an internal QA organization to provide independent data review and evaluation of QC data. The QA staff includes in its audit program an evaluation of the effectiveness of the Analytical Laboratory QA program. Subcontracted analytical laboratories are under the supervision of the Analytical Laboratory. The Analytical Laboratory is responsible for monitoring a subcontracted laboratory's methodologies and sample results and for ensuring that proper QC is maintained.

As mandated by DOE Order 5400.1, General Environmental Protection Program, the Analytical Laboratory participates in the DOE interlaboratory QA program coordinated by the DOE Environmental Measurements Laboratory. This interlaboratory program is designed to test the quality of the environmental measurements being reported to DOE by its contractors. Real or synthetic environmental samples that have been prepared and thoroughly analyzed at the program laboratory are distributed to the contractors for analysis, and the results are compiled for comparison. The Analytical Laboratory also participates in two non-DOE interlaboratory QA programs: (1) EPA's Environmental Measurement Systems Laboratory Program for radioactive materials and (2) the National Institute for Occupational Safety and Health Proficiency Analytical Testing Program for airborne metals, silica, and asbestos. A summary of the 1995 Analytical Laboratory's results for the DOE and EPA interlaboratory QA programs are provided in Table 9. The accuracy of the laboratory's results can be measured by comparing the reported laboratory values with the reference values listed in Table 9.

\subsection{Data Management}

Data management objectives for environmental monitoring activities are to maximize the usefulness and protection of important program information and to minimize the record-keeping burden and cost. These objectives were achieved in 1995 through establishment and implementation of continuous, systematic, and effective controls for each phase of a record's life cycle. Records were stored on paper and electronically in a retrievable state and were protected against deterioration, damage, and loss.

Data management activities included receiving laboratory results, entering data into an ORACLE database, and formatting data for report preparation. All environmental monitoring data were permanently stored in the ORACLE database, which is maintained by DOE-GJPO. 
Records generated in support of environmental monitoring activities were subject to the requirements for maximum-level records, as specified in the Environmental Monitoring Plan (DOE 1995e) and in Section 13, "Records Management," of Rust's Management Policies Manual (Rust Geotech 1995d). 


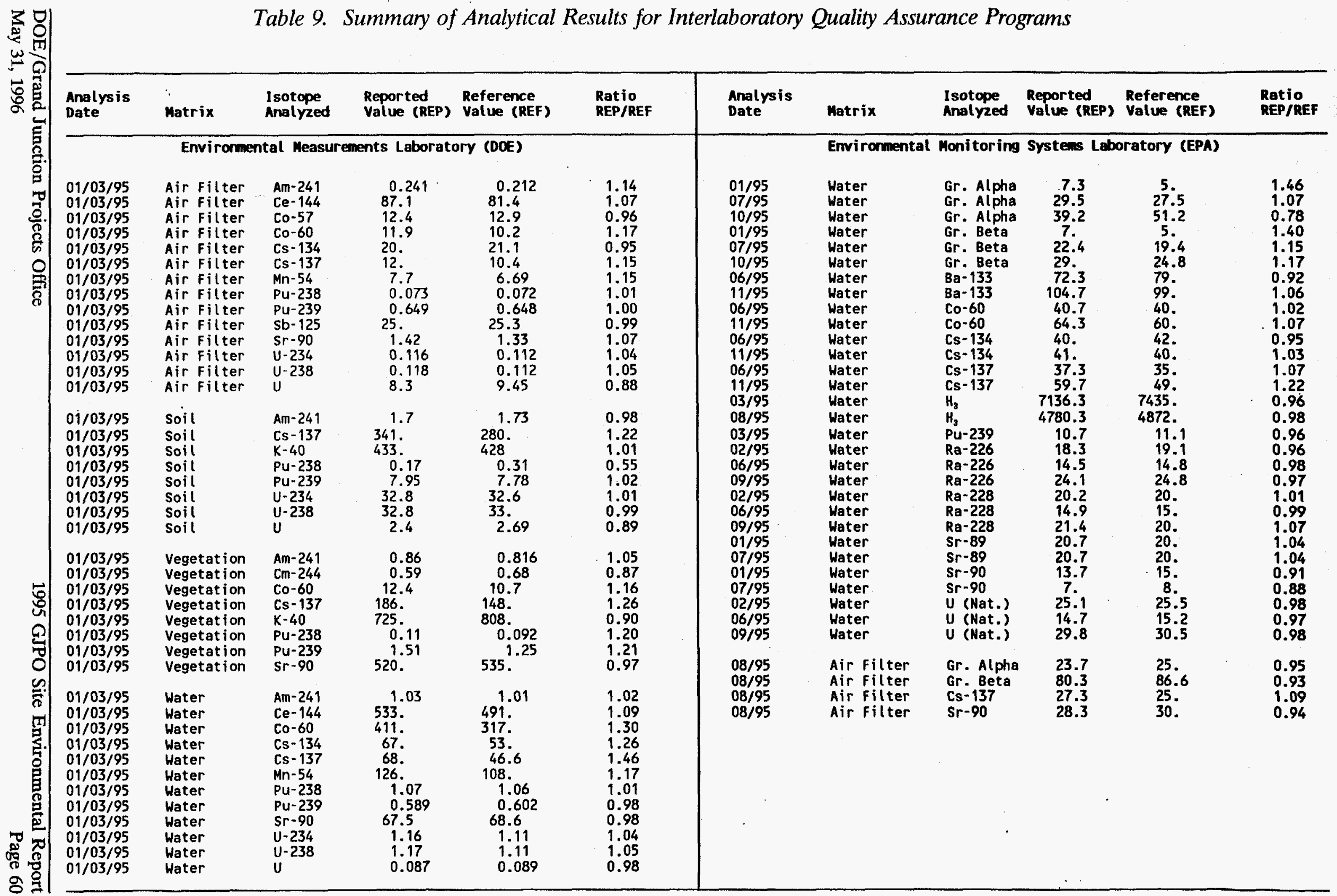




\subsection{References}

10 CFR 1021, U.S. Department of Energy, "National Environmental Policy Act Implementation Procedures, U.S. Code of Federal Regulations.

10 CFR 830, U.S. Department of Energy, "Quality Assurance Requirements," U.S. Code of Federal Regulations.

40 CFR 61, U.S. Environmental Protection Agency, "National Emission Standards for Hazardous Air Pollutants," U.S. Code of Federal Regulations.

40 CFR 124, U.S. Environmental Protection Agency, "Procedures for Decision Making," U.S. Code of Federal Regulations.

40 CFR 192, U.S. Environmental Protection Agency, "Uranium Mill Tailings Radiation Control Act," U.S. Code of Federal Regulations.

40 CFR 261.5, U.S. Environmental Protection Agency, "Special Requirements for Hazardous Waste Generated by Conditionally Exempt Small Quantity Generators," U.S. Code of Federal Regulations.

40 CFR 262, U.S. Environmental Protection Agency, "Standards Applicable to Generators of Hazardous Waste," U.S. Code of Federal Regulations.

40 CFR 263, U.S. Environmental Protection Agency, "Standards Applicable to Transporters of Hazardous Waste," U.S. Code of Federal Regulations.

40 CFR 264, U.S. Environmental Protection Agency, "Standards for Owners and Operators of Hazardous Waste Treatment, Storage, and Disposal Facilities," U.S. Code of Federal Regulations.

40 CFR 265, U.S. Environmental Protection Agency, "Interim Status Standards for Owners and Operators of Hazardous Waste Treatment, Storage, and Disposal Facilities," U.S. Code of Federal Regulations.

40 CFR 266, U.S. Environmental Protection Agency, "Standards for the Management of Specific Hazardous Wastes and Specific Types of Hazardous Waste Management Facilities," U.S. Code of Federal Regulations.

40 CFR 268, U.S. Environmental Protection Agency, "Land Disposal Restrictions," U.S. Code of Federal Regulations.

40 CFR 270, U.S. Environmental Protection Agency, "EPA Administered Permit Programs: The Hazardous Waste Permit Program," U.S. Code of Federal Regulations. 
40 CFR 403, U.S. Environmental Protection Agency, "General Pretreatment Regulations for Existing and New Sources of Pollution," U.S. Code of Federal Regulations.

Executive Order 11988, "Floodplain Management," 1977.

58 FR 17875, U.S. Department of Energy, "Schedule for Submitting Plans for the Treatment of Mixed-Waste Generated or Stored at Each Site," Federal Register.

Allen, J.R.L., 1970. Physical Processes of Sedimentation, American Elsevier Publishing Company, New York City.

American Society of Mechanical Engineers NQA-1, 1989. Quality Assurance Program Requirements for Nuclear Facilities, The American Society of Mechanical Engineers, United Engineering Center, New York City.

Henwood, P., and C. Ridolfi, 1986. Radiologic Characterization of the U.S. Department of Energy Grand Junction Projects Office Facility, GJ-41, Bendix Field Engineering Corporation, prepared for the U.S. Department of Energy, Grand Junction Operations, Grand Junction, Colorado.

Lohman, S.W., 1965. Geology and Artesian Water Supply, Grand Junction, Colorado, U.S. Geological Society, Geological Survey Professional Paper 451, prepared in cooperation with the Colorado Water Conservation Board.

McGinley, F.E., 1987. Historical Survey of the Grand Junction Projects Office FacilityHazardous (Nonradioactive) Wastes, prepared for UNC Technical Services, Inc., Grand Junction Operations, Grand Junction, Colorado.

, 1988. Addendum to Historical Survey of the Grand Junction Projects Office Facility-Hazardous (Nonradioactive) Wastes, prepared for UNC Geotech Inc., Grand Junction Operations, Grand Junction, Colorado.

Oak Ridge National Laboratory (ORNL), 1990. Requirements for Quality Control of Analytical Data, DOE/HWP-65, R-1, Oak Ridge, Tennessee.

, 1992. Requirements for Quality Control of Analytical Data for the Environmental Restoration Program, ES/ER/TM16, Oak Ridge, Tennessee.

, 1993. Environmental Technology Section Procedures Manual Volume II: Health and Safety and Technical Procedures, Grand Junction, Colorado.

, 1994. Addendum to the Work Plan for Independent Verification of the Grand Junction Projects Office Remedial Action Project, Grand Junction, Colorado.

Rust Geotech, 1995a (continually updated). Analytical Chemistry Laboratory Administrative Plan and Quality Control Procedures, U.S. Department of Energy Grand Junction Projects Office, Grand Junction, Colorado. 
Rust Geotech, 1995b (continually updated). Analytical Chemistry Laboratory Handbook of Analytical Sample-Preparation Procedures, Volumes I and II, U.S. Department of Energy Grand Junction Projects Office, Grand Junction, Colorado.

,1995c (continually updated). Environmental Procedures Catalog (Manual 116), U.S. Department of Energy Grand Junction Projects Office, Grand Junction, Colorado.

, 1995d (continually updated). Management Policies Manual (Manual 100), U.S. Department of Energy Grand Junction Projects Office, Grand Junction, Colorado.

, 1995e (continually updated). Quality Assurance Manual (Manual 101), U.S. Department of Energy Grand Junction Projects Office, Grand Junction, Colorado.

U.S. Army Corps of Engineers (COE), 1976. Flood Hazard Information, Colorado River and Tributaries, Grand Junction, Colorado, prepared for the city of Grand Junction and Mesa County, Sacramento District Corps of Engineers, Sacramento, CA.

U.S. Department of Energy (DOE), 1987. The Environmental Survey Manual, Appendix E, Vol. 4, DOE/EH-0053.

,1989a. Final Remedial Investigation/Feasibility Study-Environmental Assessment for the U.S. Department of Energy Grand Junction (Colorado) Projects Office Facility, DOE/EA-0402, prepared by UNC Geotech, Inc., for U.S. Department of Energy, U.S. Department of Energy Grand Junction Projects Office, Grand Junction, Colorado, July 1989.

, 1989b. Mesa County Floodplain Permit Application, prepared by UNC Geotech, Inc., for the U.S. Department of Energy Grand Junction Projects Office, Grand Junction, Colorado.

, 1990. Grand Junction Projects Office Remedial Action Project Declaration for the Record of Decision and Record of Decision Summary, U.S. Department of Energy, Idaho Operations Office, Grand Junction Projects Office, Grand Junction, Colorado.

, 1991. Environmental Audit of the Grand Junction Projects Office, DOE/EH-0207P, U.S. Department of Energy, Office of Environmental Audit, Washington, DC.

, 1994. AL Mixed-Waste Treatment Plan, prepared by L. Bounini, W. Desmare, J. Orban, C. Rellergert, D. Thalhammer, M. Williams, and S. Zygmunt for the DOE Albuquerque Operations Office, Albuquerque, NM. 
U.S. Department of Energy (DOE), 1995a. Air Emissions Annual Report (Subpart H, 40 CFR 61.94), Calendar Year 1994, prepared by Rust Geotech for the U.S. Department of Energy Grand Junction Projects Office, Grand Junction, Colorado.

, 1995b. DOE-GJPO Proposed Site Treatment Plan, prepared by Rust Geotech for the U.S. Department of Energy Grand Junction Projects Office, Grand Junction, Colorado.

, 1995c. First Annual Monitoring Report for the U.S. Department of Energy Grand Junction Projects Office Wetland Mitigation Project, prepared by Rust Geotech for the U.S. Department of Energy Grand Junction Projects Office, Grand Junction, Colorado.

, 1995d (continually updated). GJPO, GJPORAP, and MMTS Sampling and Analysis Plan for Environmental Monitoring, prepared by Rust Geotech for the U.S. Department of Energy Grand Junction Projects Office, Grand Junction, Colorado.

, 1995e. Grand Junction Projects Office Facility, Grand Junction Projects Office Remedial Action Project, Monticello Mill Tailings Site Environmental Monitoring Plan, P-GJPO-109, Rev. 2, prepared by Rust Geotech for the U.S. Department of Energy Grand Junction Projects Office, Grand Junction, Colorado, November 1995.

, 1995f. Grand Junction Projects Office Radioactive Effluent and OnSite Data Discharge Report, January 1, 1994, through December 31, 1994, for Grand Junction Projects Office, Grand Junction, Colorado, and Monticello Mill Tailings Site, Monticello, Utah, prepared by Rust Geotech for the U.S. Department of Energy Grand Junction Projects Office, Grand Junction, Colorado.

Calendar Year 1994, prepared by Rust Geotech for the U.S. Department of Energy Grand Junction Projects Office, Grand Junction, Colorado.

, 1995h. Ground Water Protection Management Program Plan, prepared by Rust Geotech for the U.S. Department of Energy Grand Junction Projects Office, Grand Junction, Colorado.

, 1995i. Performance Objective for Certification of Nonradioactive Hazardous Waste, prepared by Rust Geotech for the U.S. Department of Energy Grand Junction Projects Office, Grand Junction, Colorado.

, 1995j. Treatment, Storage, and Disposal Plan for GJPO Toxic, Hazardous, Radioactive, and Mixed Wastes, prepared by Rust Geotech for the U.S. Department of Energy Grand Junction Projects Office, Grand Junction, Colorado. 
U.S. Department of Energy (DOE), 1996. Draft Environmental Assessment of Facility Operations at the U.S. Department of Energy Grand Junction Projects Office, Grand Junction, Colorado, prepared by Rust Geotech for the U.S. Department of Energy Grand Junction Projects Office, Grand Junction, Colorado.

DOE Order 451.1, NEPA Compliance Program.

DOE Order 5400.1, General Environmental Protection Program.

DOE Order 5400.5, Radiation Protection of the Public and the Environment.

DOE Supplemental Directive 5440.1D, Department of Energy Albuquerque Field Office National Environmental Policy Act Compliance Program, Albuquerque Operations Office.

DOE Order 5700.6C, Quality Assurance.

DOE Order 5820.2A, Radioactive Waste Management.

U.S. Environmental Protection Agency (EPA), 1983. Results of the Nationwide Urban Runoff Program, Volume 1-Final Report, Washington, DC. $\overline{\mathrm{EPA} / 600 / 2-85-104}$ , 1985. Practical Guide for Groundwater Sampling, Edition, November 1986.

, 1986. Test Methods for Evaluating Solid Waste, SW-846, Third , 1987. Handbook-Groundwater, EPA/625/6-87/016.

, 1991. Guidance Manual for the Preparation of NPDES Permit Applications for Storm Water Discharges Associated with Industrial Activity, EPA-505/8-91-002, Office of Water, Washington, DC. 


\subsection{Distribution List}

\section{Federal Elected Officials}

\section{U.S. Senators}

The Honorable Hank Brown

SH 716 Hart Senate Office Bldg.

Washington, DC 20510-0604

(202) 224-5941

The Honorable Ben Nighthorse Campbell SR-380 Russell Senate Office Building Washington, DC 20510-0605

(202) 244-5852

\section{U.S. Congressman}

The Honorable Scott McInnis

U.S. House of Representatives 215 Cannon House Office Building

Washington, DC 20515-0603

(202) $225-4761$

or Ms. Keota Burke

Office of Senator Hank Brown

400 Rood Avenue, Room 215

Grand Junction, CO 81501

(970) 245-9553

or Mr. David Blair

Office of Senator Ben Nighthorse Campbell

743 Horizon Court, Suite 366

Grand Junction, CO 81506

(970) 241-6631

or Ms. Leigh Magee

Office of Congressman Scott McInnis

327 N. Seventh St.

Grand Junction, CO 81501

(970) 245-7107

\section{State Elected Officials}

\section{Governor}

The Honorable Roy Romer

State Capitol Building

Denver, CO 80203

(303) 866-2471

State Senator

or Mr. Bill Porter

Office of the Governor

State Capitol Building

Denver, CO 80203

(303) 866-2155

The Honorable Tilman Bishop

State Capitol Building

Denver, CO 80203

(303) 866-3077

or $2697 \mathrm{G}$ Road

Grand Junction, CO 81506

(970) 242-9230

State Representatives

The Honorable Tim Foster

District 54 - Mesa and Delta Counties

State Capitol Building

Denver, CO 80203

or 593 Village Way

(303) 866-2348

Grand Junction, CO 81501

(970) 245-8440 
State Representatives (continued)

The Honorable Dan Prinster

District 55-Mesa County

State Capitol Building

or 1203 Gunnison Avenue

Denver, CO 80203

(303) 866-2908

Grand Junction, CO 81501

(970) 241-5015

\section{Local Officials}

Mr. Mark Achen, Manager

City of Grand Junction

City Hall

250 North Fifth Street

Grand Junction, CO 81501

(970) 244-1503

\section{Mesa County Officials}

Ms. Kathy Sellman, Director

Mesa County Planning Department

P.O. Box 20000

750 Main Street

Grand Junction, CO 81501

(970) 244-1867

Mr. Steve DeFeyter

Mesa County Health Department

Environmental Health Director

515 Patterson Road

Grand Junction, CO 81505

(970) 248-6960

Mesa County Commission

P.O. Box 20000

Grand Junction, CO 81502-5010

(970) 244-1602

Colorado Department of Public Health and Environment

Mr. Jim Hams

Department of Radiation Control

222 South Sixth Street

Grand Junction, CO 81501

(970) $248-7170$

Mr. Robert True

4300 Cherry Creek Drive South

Building B2

Denver, CO 80220

(303) 692-3015
Mr. Howard Roitman

Hazardous Materials and Waste

Management Division

4300 Cherry Creek Drive South, B2

Denver, CO 80222

(303) 692-3397 
Federal Agencies-Environmental Protection Agency Region 8

Ms. Patricia Hull, Division Director

Air, Radiation, and Toxics

999 18th Street, Suite 500

Mail Code 8ART

Denver, CO 80202-2466

\section{Additional Contacts}

Battelle Pacific Northwest Laboratory

Ms. Eva Eckert Hickey

Battelle Pacific Northwest Laboratory

P.O. Box 999 MSIN-K3W-56

Richland, WA 99352

Rust Geotech

Ms. Melissa Graham-Morris

Senior Community Relations Specialist

P.O. Box 14000

Grand Junction, CO 81502

(970) 248-6141

\section{U.S. Department of Energy}

Mr. John Arthur

Acting Assistant Manager

Office of Environmental and Project Management

Albuquerque Operations Office

P.O. Box 5400

Albuquerque, NM 87115-5400

(505) 845-6034

Mr. Jacob W. Gatrell

Off-Site Program Division

Office of Southwestern Area Programs

Cloverleaf

19901 Germantown Road

Germantown, MD 20874-1290

(301) 903-7221

Mr. Bernie R. Pleau

Media Affairs Specialist

Office of Public Affairs

Albuquerque Operations Office

P.O. Box 5400

Albuquerque, NM 87115-5400

(505) 845-5951
Mr. Tom Burns, Section Chief

Colorado and Montana Section

Hazardous Waste Branch

999 18th Street, Suite 500

Mail Code 8HWM-HW

Denver, CO 80202-2466
Ms. Audrey Berry

Public Affairs Specialist

Grand Junction Projects Office

P.O. Box 2567

Grand Junction, CO 81502

(970) 248-7727

Mr. Ralph Lightner

Director

Office of Southwestern Area Programs

Cloverleaf

19901 Germantown Road

Germantown, MD 20874-1290

(301) $903-3850$

Ms. Constance Soden

Director

Environmental Protection Division

Office of Environment, Safety,

and Health

P.O. Box 5400

Albuquerque, NM 87115

(505) 845-5586 
U.S. Department of Energy (continued)

Mr. Glen Podonsky

Office of the Principal Deputy Assistant Secretary

for Environment, Safety, and Health

19901 Germantown Road

Germantown, MD 20585

(301) $903-3727$

Administrative Record/Information Repository

U.S. Department of Energy

Grand Junction Projects Office

Public Reading Room

Building 810, Room 162

2597 B 3/4 Road

Grand Junction, $\mathrm{CO} 81503$

(970) 248-6612
Mr. Richard Day

Office of Risk Analysis and Technology 19901 Germantown Road

Germantown, MD 20585

(301) 903-8371

Mesa County Public Library

Government Documents Section

530 Grand Avenue

Grand Junction, CO 81501

(970) 243-4442 
Appendix A

Monitoring Data 
I

I

I

I

I

I

,

I

I

I

,

,

I

| 
Table A-1. Sewer-Effluent Chemistry Data for the GJPO Facility During 1995a

\begin{tabular}{|c|c|c|c|c|c|c|c|c|c|c|c|c|}
\hline $\begin{array}{l}\text { Ticket } \\
\text { Number }\end{array}$ & $\begin{array}{c}\text { Samplé } \\
\text { Date }\end{array}$ & $\underset{(\mu \mathrm{Ag} / \mathrm{L})}{\mathrm{Ag}}$ & $\begin{array}{l}\text { Alpha } \\
(\mathrm{pC} i / L)^{b}\end{array}$ & $\begin{array}{c}A m-241 \\
(\mathrm{pCi} / \mathrm{L})^{\mathrm{b}}\end{array}$ & $\begin{array}{r}\mathrm{Am}-241^{\mathrm{C}} \\
(\mathrm{pCi} / \mathrm{L})^{\mathrm{b}}\end{array}$ & $\begin{array}{l}\text { As } \\
(\mu \mathrm{g} / \mathrm{L})\end{array}$ & $\begin{array}{l}\text { Beta } \\
(\mathrm{pCi} / \mathrm{L})^{b}\end{array}$ & $\begin{array}{l}\text { BOD }^{d} \\
(m g / L)\end{array}$ & $\begin{array}{c}\mathrm{Cr} \\
(\mu g / L)\end{array}$ & $\begin{array}{l}\mathrm{MH}_{3} \\
(\mu \mathrm{L} / \mathrm{L})\end{array}$ & $\begin{array}{l}0 i l^{e} \\
(m g / L)\end{array}$ & $\begin{array}{c}\text { PCBs/ } \\
\text { Pesticides } \\
(\mu g / L)\end{array}$ \\
\hline NBB-361 & $01 / 04 / 1995$ & No Data & 9.6 & No Data & No Data & No Data & 8.4 & No Data & No Data & No Data & No Data & No Data \\
\hline NBB -362 & $01 / 27 / 1995$ & No Data & $<14.2$ & No Data & No Data & No Data & $<14.2$ & No Data & No Data & No Data & No Data & No Data \\
\hline NBB -363 & $03 / 07 / 1995$ & No Data & $<8.8$ & No Data & No Data & No Data & $<7.6$ & No Data & No Data & No Data & No Data & No Data \\
\hline NBB -364 & $03 / 08 / 1995$ & $<1.0$ & $<10.2$ & No Data & No Data & No Data & 8.0 & 77.0 & No Data & 11600 & 52.0 & No Detect \\
\hline NBB-365 & $03 / 15 / 1995$ & No Data & No Data & No Data & No Data & No Data & No Data & No Data & No Data & No Data & 26.0 & No Data \\
\hline$N B B-366$ & $03 / 16 / 1995$ & No Data & No Data & No Data & No Data & No Data & No Data & No Data & No Data & No Data & 45.0 & No Data \\
\hline NBB -367 & $04 / 12 / 1995$ & 16.1 & No Data & No Data & No Data & No Data & No Data & 90.0 & No Data & 18100 & 33.0 & No Detect \\
\hline NBB-368 & $04 / 21 / 1995$ & No Data & $<14.0$ & No Data & No Data & No Data & 23.2 & No Data & No Data & No Data & No Data & No Data \\
\hline NBB -369 & $05 / 26 / 1995$ & No Data & 21.2 & No Data & No Data & No Data & $<14.7$ & No Data & No Data & No Data & No Data & No Data \\
\hline NBB -370 & $06 / 14 / 1995$ & $<4.0$ & 97 & No Data & No Data & No Data & 29.2 & 37.0 & No Data & 12700 & 17.0 & No Detect \\
\hline NBB-371 & $06 / 14 / 1995$ & $<4.0$ & 74 & No Data & No Data & No Data & $<23$ & 37.0 & No Data & 13400 & 18.0 & No Detect \\
\hline NBB -372 & $06 / 29 / 1995$ & No Data & 116 & 0.04 & .19 & No Data & 19.6 & No Data & No Data & No Data & No Data & No Data \\
\hline NBB -373 & $07 / 19 / 1995$ & No Data & 253 & 0.036 & .051 & No Data & 111 & No Data & No Data & No Data & No Data & No Data \\
\hline NBB -374 & $08 / 09 / 1995$ & $<4.0$ & No Data & No Data & No Data & No Data & No Data & 60.0 & No Data & 17100 & 6.0 & No Detect \\
\hline NBB -375 & $08 / 31 / 1995$ & No Data & 192 & No Data & No Data & No Data & 73.1 & No Data & No Data & No Data & No Data & No Data \\
\hline$N B F-126$ & $10 / 04 / 1995$ & No Data & 120 & No Data & No Data & No Data & 48.3 & No Data & No Data & No Data & No Data & No Data \\
\hline NBF -127 & $11 / 16 / 1995$ & No Data & 40 & No Data & No Data & $<4.0$ & 24.1 & No Data & $<5.0$ & No Data & No Data & No Data \\
\hline$N B F-128$ & $11 / 29 / 1995$ & -3.0 & 33 & No Data & No Data & No Data & $<20$ & 65.0 & No Data & 19800 & 41.4 & No Detect \\
\hline NBF -129 & $12 / 22 / 1995$ & No Data & 24.9 & No Data & No Data & No Data & $<24$ & No Data & No Data & No Data & No Data & No Data \\
\hline
\end{tabular}

$a_{A}$ "<" symbol indicates that the maximum concentration was below the detection limit (number shown is detection 1 imit). A " $"$ indicates an approximate value (the value was outside the limits for which the instrument was calibrated).

The values listed multiplied by $10^{-9}$ will result in units of microcuries per milliliter.

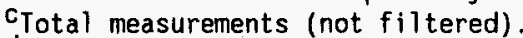

dBiological oxygen demand.

eil and grease. 
Table A-1 (continued). Sewer-Effluent Chemistry Data for the GJPO Facility During 1995a

\begin{tabular}{|c|c|c|c|c|c|c|c|c|c|c|c|c|}
\hline $\begin{array}{l}\text { Ticket } \\
\text { Number }\end{array}$ & $\begin{array}{c}\text { Sample } \\
\text { Date }\end{array}$ & $\mathrm{pH}$ & $\begin{array}{c}\mathrm{Pu}-238 \\
(\mathrm{pCi} / L)^{b}\end{array}$ & $\begin{array}{r}\mathrm{Pu}-238^{\mathrm{c}} \\
(\mathrm{pCi} / \mathrm{L})^{\mathrm{b}}\end{array}$ & $\begin{array}{r}P u-239+240 \\
(p C i / L)^{b}\end{array}$ & $\begin{array}{c}\mathrm{Pu}-239+240^{\mathrm{C}} \\
(\mathrm{pCi} / \mathrm{L})^{\mathrm{b}}\end{array}$ & $\begin{array}{l}\mathrm{Ra}-226 \\
(\mathrm{pCi} / \mathrm{L})^{\mathrm{b}}\end{array}$ & $\begin{array}{l}\operatorname{Ra-226} \mathrm{c} \\
(\mathrm{pCi} / \mathrm{L})^{\mathrm{b}}\end{array}$ & $\begin{array}{l}\text { Se } \\
(\mu g / L)\end{array}$ & $\begin{array}{c}\text { Solidsc } \\
(\mathrm{X})\end{array}$ & $\begin{array}{l}\mathrm{Sr}-90 \\
(\mathrm{pCi} / \mathrm{L})^{b}\end{array}$ & $\begin{array}{l}\mathrm{Sr}-90^{\mathrm{c}} \\
(\mathrm{pCi} / \mathrm{L})^{b}\end{array}$ \\
\hline NBB-361 & $01 / 04 / 1995$ & No Data & No Data & No Data & No Data & No Data & No Data & No Data & No Data & No Data & No Data & No Data \\
\hline NBB-362 & $01 / 27 / 1995$ & No Data & No Data & No Data & No Data & No Data & No Data & No Data & No Data & No Data & No Data & No Data \\
\hline$N B B-363$ & $03 / 07 / 1995$ & No Data & No Data & No Data & No Data & No Data & No Data & No Data & No Data & No Data & No Data & No Data \\
\hline NBB-364 & $03 / 08 / 1995$ & 7.79 & No Data & No Data & No Data & No Data & No Data & No Data & No Data & No Data & No Data & No Data \\
\hline NBB-365 & $03 / 15 / 1995$ & No Data & No Data & No Data & No Data & No Data & No Data & No Data. & No Data & No Data & No Data & No Data \\
\hline NBB-366 & $03 / 16 / 1995$ & No Data & No Data & No Data & No Data & No Data & No Data & No Data & No Data & No Data & No Data & No Data \\
\hline NBB -367 & $04 / 12 / 1995$ & No Data & No Data & No Data & No Data & No Data & No Data & No Data & No Data & No Data & No Data & No Data \\
\hline NBB-368 & $04 / 21 / 1995$ & No Data & No Data & No Data & No Data & No Data & No Data & No Data & No Data & No Data & No Data & No Data \\
\hline NBB - 369 & $05 / 26 / 1995$ & No Data & No Data & No Data & No Data & No Data & No Data & No Data & No Data & No Data & No Data & No Data \\
\hline NBB-370 & $06 / 14 / 1995$ & 7.19 & No Data & No Data & No Data & No Data & No Data & No Data & No Data & No Data & No Data & No Data \\
\hline NBB-371 & $06 / 14 / 1995$ & No Data & No Data & No Data & No Data & No Data & No Data & No Data & No Data & No Data & No Data & No Data \\
\hline NBB -372 & $06 / 29 / 1995$ & No Data & 0.018 & .139 & $<0.024$ & 0.256 & 0.19 & .65 & No Data & 0.009 & $<1.08$ & $<4.41$ \\
\hline NBB -373 & $07 / 19 / 1995$ & No Data & 0.03 & .037 & $<0.004$ & 0.002 & 0.21 & .249 & No Data & 0.0091 & $<1.37$ & $<1.37$ \\
\hline NBB-374 & $08 / 09 / 1995$ & 7.25 & No Data & No Data & No Data & No Data & No Data & No Data & No Data & No Data & No Data & No Data \\
\hline NBB-375 & $08 / 31 / 1995$ & No Data & No Data & No Data & No Data & No Data & No Data & No Data & No Data & No Data & No Data & No Data \\
\hline NBF - 126 & $10 / 04 / 1995$ & No Data & No Data & No Data & No Data & No Data & No Data & No Data & No Data & No Data & No Data & No Data \\
\hline NBF-127 & $11 / 16 / 1995$ & No Data & No Data & No Data & No Data & No Data & No Data & No Data & $<5.0$ & No Data & No Data & No Data \\
\hline$N B F-128$ & $11 / 29 / 1995$ & 7.84 & No Data & No Data & No Data & No Data & No Data & No Data & No Data & No Data & No Data & No Data \\
\hline NBF - 129 & $12 / 22 / 1995$ & No Data & No Data & No Data & No Data & No Data & No Data & No Data & No Data & No Data & No Data & No Data \\
\hline
\end{tabular}

$a_{A}$ " $<"$ symbol indicates that the maximum concentration was below the detection limit (number shown is detection limit).

The values listed multiplied by $10^{-9}$ will result in units of'microcuries per milliliter.

$\mathrm{c}_{\text {Total }}$ measurements (not filtered). 
Table A-I (continued). Sewer-Effluent Chemistry Data for the GJPO Facility During 1995a

\begin{tabular}{|c|c|c|c|c|c|c|c|c|c|c|c|c|}
\hline $\begin{array}{l}\text { Ticket } \\
\text { Number }\end{array}$ & $\begin{array}{l}\text { Sample } \\
\text { Date }\end{array}$ & $\begin{array}{c}\mathrm{TDS}^{\mathrm{b}} \\
(\mathrm{mg} / \mathrm{L})\end{array}$ & $\begin{array}{c}\text { Temperature } \\
\left({ }^{\circ} \mathrm{C}\right)\end{array}$ & $\begin{array}{l}\text { Th-228 } \\
(\mathrm{pCi} / \mathrm{L})^{\mathrm{c}}\end{array}$ & $\begin{array}{r}\text { Th-228 } \\
(\mathrm{pC} i / L)^{\mathrm{C}}\end{array}$ & $\begin{array}{l}\text { Th-230 } \\
(\mathrm{pCi} / L)^{\mathrm{c}}\end{array}$ & $\begin{array}{l}\text { Th-230c } \\
(\mathrm{pCi} / \mathrm{L})^{\mathrm{c}}\end{array}$ & $\begin{array}{l}\text { Th-232 } \\
(p C j / L)^{c}\end{array}$ & $\begin{array}{l}\text { Th-232d } \\
(\mathrm{pCi} / L)^{\mathrm{C}}\end{array}$ & $\begin{array}{c}\text { TsSe } \\
(m g / L)\end{array}$ & $\begin{array}{c}v \\
(\mu / L)\end{array}$ & $\begin{array}{c}\mathrm{U}-234 \\
(\mathrm{pCi} / \mathrm{L})^{\mathrm{C}}\end{array}$ \\
\hline $\begin{array}{l}\text { NBB }-361 \\
\text { NBB-362 } \\
\text { NBB }-363 \\
\text { NBB-364 } \\
\text { NBB-365 } \\
\text { NBB }-366 \\
\text { NBB-367 } \\
\text { NBB-368 } \\
\text { NBB }-369 \\
\text { NBB-370 } \\
\text { NBB }-371 \\
\text { NBB }-372 \\
\text { NBB }-373 \\
\text { NBB }-374 \\
\text { NBB }-375 \\
\text { NBF }-126 \\
\text { NBF-127 } \\
\text { NBF }-128 \\
\text { NBF }-129\end{array}$ & $\begin{array}{l}01 / 04 / 1995 \\
01 / 27 / 1995 \\
03 / 07 / 1995 \\
03 / 08 / 1995 \\
03 / 15 / 1995 \\
03 / 16 / 1995 \\
04 / 12 / 1995 \\
04 / 21 / 1995 \\
05 / 26 / 1995 \\
06 / 14 / 1995 \\
06 / 14 / 1995 \\
06 / 29 / 1995 \\
07 / 19 / 1995 \\
08 / 09 / 1995 \\
08 / 31 / 1995 \\
10 / 04 / 1995 \\
11 / 16 / 1995 \\
11 / 29 / 1995 \\
12 / 22 / 1995\end{array}$ & $\begin{array}{l}\text { No Data } \\
\text { No Data } \\
\text { No Data } \\
\sim 362 \\
\text { No Data } \\
\text { No Data } \\
470 \\
\text { No Data } \\
\text { No Data } \\
720 \\
720 \\
\text { No Data } \\
\text { No Data } \\
868 \\
\text { No Data } \\
\text { No Data } \\
\text { No Data } \\
545 \\
\text { No Data }\end{array}$ & $\begin{array}{l}\text { No Data } \\
\text { No Data } \\
\text { No Data } \\
\text { 13.5 } \\
\text { No Data } \\
\text { No Data } \\
\text { No Data } \\
\text { No Data } \\
\text { No Data } \\
\text { 18.7 } \\
\text { No Data } \\
\text { No Data } \\
\text { No Data } \\
\text { 22.5 } \\
\text { No Oata } \\
\text { No Data } \\
\text { No Data } \\
\text { 15.5 } \\
\text { No Data }\end{array}$ & $\begin{array}{l}\text { No Data } \\
\text { No Data } \\
\text { No Data } \\
\text { No Data } \\
\text { No Data } \\
\text { No Data } \\
\text { No Data } \\
\text { No Data } \\
\text { No Data } \\
\text { No Data } \\
\text { No Data } \\
\text { O.07 } \\
\text { <0.076 } \\
\text { No Data } \\
\text { No Data } \\
\text { No Data } \\
\text { No Data } \\
\text { No Data } \\
\text { No Data }\end{array}$ & $\begin{array}{l}\text { No Data } \\
\text { No Data } \\
\text { No Data } \\
\text { No Data } \\
\text { No Data } \\
\text { No Data } \\
\text { No Data } \\
\text { No Data } \\
\text { No Data } \\
\text { No Data } \\
\text { No Data } \\
.95 \\
\text { O.046 } \\
\text { No Data } \\
\text { No Data } \\
\text { No Data } \\
\text { No Data } \\
\text { No Data } \\
\text { No Data }\end{array}$ & $\begin{array}{l}\text { No Data } \\
\text { No Data } \\
\text { No Data } \\
\text { No Data } \\
\text { No Data } \\
\text { No Data } \\
\text { No Data } \\
\text { No Data } \\
\text { No Data } \\
\text { No Data } \\
\text { No Data } \\
\text { <0.04 } \\
\text { O.31 } \\
\text { No Data } \\
\text { No Data } \\
\text { No Data } \\
\text { No Data } \\
\text { No Data } \\
\text { No Data }\end{array}$ & $\begin{array}{l}\text { No Data } \\
\text { No Data } \\
\text { No Data } \\
\text { No Data } \\
\text { No Data } \\
\text { No Data } \\
\text { No Data } \\
\text { No Data } \\
\text { No Data } \\
\text { No Data } \\
\text { No Data } \\
0.66 \\
\text { No Data } \\
\text { No Data } \\
\text { No Data } \\
\text { No Data } \\
\text { No Data } \\
\text { No Data }\end{array}$ & $\begin{array}{l}\text { No Data } \\
\text { No Data } \\
\text { No Data } \\
\text { No Data } \\
\text { No Data } \\
\text { No Data } \\
\text { No Data } \\
\text { No Data } \\
\text { No Data } \\
\text { No Data } \\
\text { No Data } \\
0.02 \\
\text { <0.027 } \\
\text { No Data } \\
\text { No Data } \\
\text { No Data } \\
\text { No Data } \\
\text { No Data } \\
\text { No Data }\end{array}$ & $\begin{array}{l}\text { No Data } \\
\text { No Data } \\
\text { No Data } \\
\text { No Data } \\
\text { No Data } \\
\text { No Data } \\
\text { No Data } \\
\text { No Data } \\
\text { No Data } \\
\text { No Data } \\
\text { No Data } \\
\text {.46 } \\
\text { O.021 } \\
\text { No Data } \\
\text { No Data } \\
\text { No Data } \\
\text { No Data } \\
\text { No Data } \\
\text { No Data }\end{array}$ & $\begin{array}{l}\text { No Data } \\
\text { No Data } \\
\text { No Data } \\
40.0 \\
\text { No Data } \\
\text { No Data } \\
\text {-44.0 } \\
\text { No Data } \\
\text { No Data } \\
\sim 26.0 \\
\sim 32.0 \\
\text { No Data } \\
\text { No Data } \\
\text { 38.0 } \\
\text { No Data } \\
\text { No Data } \\
\text { No Data } \\
44.0 \\
\text { No Data }\end{array}$ & $\begin{array}{l}\text { No Data } \\
\text { No Data } \\
\text { No Data } \\
\text { No Data } \\
\text { No Data } \\
\text { No Data } \\
\text { No Data } \\
\text { No Data } \\
\text { No Data } \\
\text { No Data } \\
\text { No Data } \\
\text { No Data } \\
269 \\
\text { No Data } \\
143 \\
82.0 \\
\text { No Data } \\
\text { No Data } \\
\text { No Data }\end{array}$ & $\begin{array}{l}\text { No Data } \\
\text { No Data } \\
\text { No Data } \\
\text { No Data } \\
\text { No Data } \\
\text { No Data } \\
\text { No Data } \\
\text { No Data } \\
\text { No Data } \\
\text { No Data } \\
\text { No Data } \\
26.93 \\
66.32 \\
\text { No Data } \\
\text { No Data } \\
\text { No Data } \\
\text { No Data } \\
\text { No Data } \\
\text { No Data }\end{array}$ \\
\hline
\end{tabular}

$a_{A}$ "<" symbol indicates that the maximum concentration was below the detection limit (number shown is detection limit). A " " indicates an approximate value (the value was outside the limits for which the instrument was calibrated).

Total dissolved solids.

cThe values listed multiplied by $10^{-9}$ will result in units of microcuries per milliliter.

dotal measurements (not filtered).

Total suspended solids. 
Table A-1 (continued). Sewer-Effluent Chemistry Data for the GJPO Facility During 1995

\begin{tabular}{|c|c|c|c|c|c|c|}
\hline $\begin{array}{l}\text { Ticket } \\
\text { Number }\end{array}$ & $\begin{array}{l}\text { Sample } \\
\text { Date }\end{array}$ & $\begin{array}{c}u-234^{a} \\
(p C i / L)^{b}\end{array}$ & $\begin{array}{c}\mathrm{u}-235 \\
(\mathrm{pC} i / L)^{b}\end{array}$ & $\begin{array}{c}\mathrm{U}-235^{\mathrm{a}} \\
\left({ }^{\mathrm{C}} \mathrm{C} / \mathrm{L} /\right)^{\mathrm{b}}\end{array}$ & $\begin{array}{c}\mathrm{U}-238 \\
(\mathrm{pCi} / L)^{\mathrm{b}}\end{array}$ & $\begin{array}{c}\mathrm{U}-238^{\mathrm{a}} \\
(\mathrm{pCl} / \mathrm{L})^{\mathrm{b}}\end{array}$ \\
\hline NBB-361 & $01 / 04 / 1995$ & No Data & No Data & No Data & No Data & No Data \\
\hline NBB-362 & $01 / 27 / 1995$ & No Data & No Data & No Data & No Data & No Data \\
\hline NBB -363 & $03 / 07 / 1995$ & No Data & No Data & No Data & No Data & No Data \\
\hline NBB-364 & $03 / 08 / 1995$ & No Data & No Data & No Data & No Data & No Data \\
\hline NBB-365 & $03 / 15 / 1995$ & No Data & No Data & No Data & No Data & No Data \\
\hline NBB-366 & $03 / 16 / 1995$ & No Data & No Data & No Data & No Data & No Data \\
\hline NBB -367 & $04 / 12 / 1995$ & No Data & No Data & No Data & No Data & No Data \\
\hline NBB-368 & $04 / 21 / 1995$ & No Data & No Data & No Data & No Data & No Oata \\
\hline NBB -369 & $05 / 26 / 1995$ & No Data & No Data & No Data & No Data & No Data \\
\hline NBB -370 & $06 / 14 / 1995$ & No Data & No Data & No Data & No Data & No Data \\
\hline NBB-371 & $06 / 14 / 1995$ & No Data & No Data & No Data & No Data & No Data \\
\hline NBB - 372 & $06 / 29 / 1995$ & 331.29 & 1.11 & 13.62 & 31.25 & 354.3 \\
\hline NBB -373 & $07 / 19 / 1995$ & 86.52 & 2.88 & 3.794 & 63.66 & 83.77 \\
\hline NBB -374 & $08 / 09 / 1995$ & No Data & No Data & No Data & No Data & No Data \\
\hline NBB -375 . & $08 / 31 / 1995$ & No Data & No Data & No Data & No Data & No Data \\
\hline$N B F-126$ & $10 / 04 / 1995$ & No Data & No Data & No Data & No Data & No Data \\
\hline$N B F-127$ & $11 / 16 / 1995$ & No Data & No Data & No Data & No Data & No Data \\
\hline$N B F-128$ & $11 / 29 / 1995$ & No Data & No Data & No Data & No Data & No Data \\
\hline NBF -129 & $12 / 22 / 1995$ & No Data & No Data & No Data & No Data & No Data \\
\hline
\end{tabular}

a Total measurements (not filtered)

bThe values 1 isted multiplied by $10^{-9}$ will result in units of microcuries per milliliter. 
Table A-2. Surface-Water Chemistry Data Collected At and Near the GJPO During 1995 a

\begin{tabular}{|c|c|c|c|c|c|c|c|c|c|c|c|}
\hline $\begin{array}{l}\text { Sample } \\
\text { Location }\end{array}$ & $\begin{array}{l}\text { Ticket } \\
\text { Number }\end{array}$ & $\begin{array}{l}\text { Sample } \\
\text { Date }\end{array}$ & $\begin{array}{c}\text { Alkalinity } \\
\text { (as } \mathrm{CaCO}_{3} \text { ) } \\
\text { (ppm) }\end{array}$ & $\begin{array}{c}\text { Alpha } \\
(\mathrm{pCi} / \mathrm{L})^{\mathrm{b}}\end{array}$ & $\begin{array}{c}\text { As } \\
(\mu \mathrm{g} / \mathrm{L})\end{array}$ & $\underset{(\mu \mathrm{g} / \mathrm{L})}{\mathrm{Ba}}$ & $\underset{(\mathrm{mg} / \mathrm{L})}{\mathrm{Ca}}$ & $\underset{(\mu \mathrm{gg} / \mathrm{L})}{\mathrm{Cd}}$ & $\begin{array}{c}\mathrm{CDT}^{\mathrm{C}} \\
(\mu \operatorname{mhos} / \mathrm{cm})\end{array}$ & $\underset{(\mathrm{mg} / \mathrm{L})}{\mathrm{Cl}}$ & $\underset{(\mu / L)}{C r}$ \\
\hline Upper Gunnison & NBD-301 & $06 / 12 / 1995$ & 64 & $<10.9$ & $<3.0$ & $\sim 43.6$ & 38.9 & $<1.0$ & 336 & 1.9 & $<4,0$ \\
\hline Upper Mid Gunnison & NBD-302 & $08 / 12 / 1995$ & 92 & $<10.8$ & -3.3 & $\sim 38.4$ & 37.3 & $<1.0$ & 336 & 1.9 & $<4.0$ \\
\hline Middle Gunnison & NBD-304 & $06 / 12 / 1995$ & 78 & $<10.8$ & $<3.0$ & $\sim 38.1$ & 37.2 & $<1.0$ & 337 & 2.0 & $<4.0$ \\
\hline Lower Gunn i son & NBD -303 & $06 / 12 / 1995$ & 76 & $<17.9$ & $<3.0$ & $\sim 39.6$ & 37.6 & $<1.0$ & 1032 & 1.9 & $<4.0$ \\
\hline \multirow{2}{*}{ North Pond } & NBD -305 & $06 / 12 / 1995$ & 194 & 680 & $<3.0$ & -15.3 & 290 & $<1.0$ & 6440 & 439 & $<4.0$ \\
\hline & NBD-306 & $06 / 12 / 1995$ & No Data & 610 & $<3.0$ & -15.1 & 290 & $<1.0$ & No Data & 438 & $<4.0$ \\
\hline South Pond & NBD -309 & $06 / 13 / 1995$ & 82 & 351 & $\sim 10.8$ & $\sim 21.3$ & 311 & $<1.0$ & 3200 & 111 & $<4.0$ \\
\hline Wet land Area & NBD-308 & $06 / 12 / 1995$ & 282 & 337 & $<3.0$ & $\sim 28.1$ & 441 & $<1.0$ & 5960 & 339 & $<4.0$ \\
\hline
\end{tabular}

${ }_{A} A$ " $<$ " indicates that the maximum concentration was below the detection limit (number shown is detection limit). A " $"$ indicates an approximate value (the value was outside the limits for which the instrument was calibrated).

The values listed multiplied by $10^{-9}$ will result in units of microcuries per milliliter.

${ }^{\mathrm{C} C o n d u c t i v i t y}$ measured in micromhos per centimeter. 
Table A-2 (continued). Surface-Water Chemistry Data Collected At and Near the GJPO During 1995a

\begin{tabular}{|c|c|c|c|c|c|c|c|c|c|c|c|}
\hline $\begin{array}{l}\text { Sample } \\
\text { Location }\end{array}$ & $\begin{array}{l}\text { Ticket } \\
\text { Number }\end{array}$ & $\begin{array}{l}\text { Sample } \\
\text { Date }\end{array}$ & $\begin{array}{c}\mathrm{Fe} \\
(\mu \mathrm{g} / \mathrm{L})\end{array}$ & $\underset{(\mathrm{mg} / L)}{K}$ & $\underset{(\mathrm{mg} / \mathrm{L})}{\mathrm{Mg}}$ & $\underset{(\mu \mathrm{m} / \mathrm{L})}{\mathrm{Mn}}$ & $\begin{array}{c}\text { Mo } \\
(\mu \mathrm{pg} / \mathrm{L})\end{array}$ & $\underset{(\mathrm{mg} / \mathrm{L})}{\mathrm{Ma}}$ & $\begin{array}{c}\mathrm{NO}_{3} \\
(\mathrm{mg} / \mathrm{L})\end{array}$ & $\underset{(\mu g / L)}{\mathrm{Pb}}$ & pH \\
\hline Upper Gunnison & NBD-301 & $06 / 12 / 1995$ & -41.9 & $<1.0$ & 10.6 & 25.6 & $<17.0$ & 14.4 & 0.98 & $<1.0$ & 7.83 \\
\hline Upper Mid Gunnison & NBD- 302 & $06 / 12 / 1995$ & $\sim 8.4$ & -1.4 & 10.5 & $\sim 7.0$ & $<17.0$ & 13.7 & 0.93 & $<1.0$ & 7.79 \\
\hline Middle Gunnison & $N B D-304$ & $06 / 12 / 1995$ & $\sim 23.9$ & $<1.0$ & 10.5 & $\sim 9.5$ & $<17.0$ & 13.9 & 0.97 & $<1.0$ & 7.92 \\
\hline Lower Gunnison & NBD-303 & $06 / 12 / 1995$ & -5.8 & $\sim 1.4$ & 10.6 & $\sim 5.3$ & $<17.0$ & 13.8 & 0.96 & $<1.0$ & 7.58 \\
\hline North Pond & NBD- 305 & $06 / 12 / 1995$ & $<5.0$ & 24.8 & 235 & 46.6 & -46.3 & 1030 & $\sim 0.03$ & $<1.0$ & 8.43 \\
\hline & $N B D-306$ & $06 / 12 / 1995$ & $<5.0$ & 24.5 & 236 & 45.4 & 60.1 & 1030 & $<0.02$ & $<1.0$ & No Data \\
\hline South Pond & NBD-309 & $06 / 13 / 1995$ & $<5.0$ & 13.7 & 72.2 & 58.5 & 94.1 & 401 & $<0.01$ & $<1.0$ & 7.98 \\
\hline Wet 1 and Area & NBD -308 & $06 / 12 / 1995$ & -37.7 & 39.2 & 124 & 373 & . 197 & 907 & $\sim 0.05$ & $<1.0$ & 7.73 \\
\hline
\end{tabular}

$a_{A}$ "<" indicates that the maximum concentration was below the detection limit (number shown is detection limit). A " $"$ indicates an approximate value (the value was outside the limits for which the instrument was calibrated). 


\begin{tabular}{|c|c|c|c|c|c|c|c|c|c|c|c|c|}
\hline \multirow{10}{*}{ 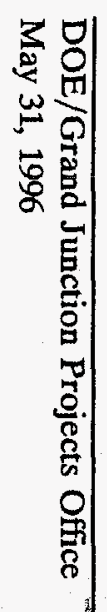 } & \multicolumn{12}{|c|}{ Table A-2 (continued). } \\
\hline & $\begin{array}{c}\text { Sample } \\
\text { Location }\end{array}$ & $\begin{array}{l}\text { Ticket } \\
\text { Number }\end{array}$ & $\begin{array}{l}\text { Sample } \\
\text { Date }\end{array}$ & $\begin{array}{c}\mathrm{Ra}-226 \\
(\mathrm{pCi} / \mathrm{L})^{\mathrm{b}}\end{array}$ & $\begin{array}{c}\mathrm{Ra}-228 \\
(\mathrm{pCi} / L)^{\mathrm{b}}\end{array}$ & $\begin{array}{c}\text { Se } \\
(\mu \mathrm{g} / \mathrm{L})\end{array}$ & $\underset{(\mathrm{mg} / \mathrm{L})}{\mathrm{SO}_{4}}$ & $\underset{(\mathrm{mg} / \mathrm{L})}{\mathrm{TDS}^{\mathrm{C}}}$ & $\begin{array}{l}\text { Temperature } \\
\left({ }^{\circ} \tau\right)\end{array}$ & $\begin{array}{c}\mathrm{Th}-230 \\
(\mathrm{pCi} / L)^{b}\end{array}$ & $\begin{array}{l}\text { Th-232 } \\
(p C i / L)^{b}\end{array}$ & $\underset{(\mathrm{mg} / \mathrm{L})}{\mathrm{TOC}}$ \\
\hline & Upper Gunnison & NBD-301 & $06 / 12 / 1995$ & $<0.5$ & $<3.5$ & $\sim 3.1$ & 79.3 & $\sim 213$ & 12.9 & $<1.0$ & $<1.0$ & 10.8 \\
\hline & Upper Mid Gunnison & NBD-302 & $06 / 12 / 1995$ & $<0.5$ & $<2.7$ & $<2.2$ & 77.3 & $\sim 208$ & 14.0 & $<1.0$ & $<1.0$ & 8.6 \\
\hline & Middle Gunnison & NBD-304 & $06 / 12 / 1995$ & $<0.5$ & $<2.1$ & -2.5 & 78.5 & $\sim 210$ & 13.2 & $<1.0$ & $<1.0$ & 6.4 \\
\hline & Lower Gunnison & NBD -303 & $06 / 12 / 1995$ & $<0.5$ & $<3.0$ & -2.8 & 78.6 & -218 & 12.2 & $<1.0$ & $<1.0$ & 6.8 \\
\hline & North Pond & NBD-305 & $06 / 12 / 1995$ & $<0.5$ & $<3.0$ & $<2.2$ & 3140 & 5640 & 23.5 & $<1.0$ & $<1.0$ & 25.6 \\
\hline & & NBD-306 & $06 / 12 / 1995$ & $<0.5$ & $<3.8$ & $<2.2$ & 3140 & 5720 & No Data & $<1.0$ & $<1.0$ & 19.5 \\
\hline & South Pond & NBD-309 & $06 / 13 / 1995$ & $<0.5$ & $<4.4$ & $\sim 4.8$ & 1640 & 2820 & 21.5 & $<1.0$ & $<1.0$ & 29.1 \\
\hline & Wet land Area & NBD -308 & $06 / 12 / 1995$ & $<0.5$ & $<3.0$ & $<10.0$ & 2880 & 5280 & 28.5 & $<1.0$ & $<1.0$ & 25.1 \\
\hline
\end{tabular}

$a_{A}$ "<" indicates that the maximum concentration was below the detection limit (number shown is detection limit). A " " indicates an approximate value (the value was outside the limits for which the instrument was calibrated).

The values 1 isted multiplied by $10^{-9}$ will result in units of microcuries per milliliter.

CTotal dissolved solids.

dotal organic carbon. 
Table A-2 (continued). Surface-Water Chemistry Data Collected At and Near the GJPO During 1995a

\begin{tabular}{|c|c|c|c|c|c|c|}
\hline $\begin{array}{l}\text { Sample } \\
\text { Location }\end{array}$ & $\begin{array}{l}\text { Ticket } \\
\text { Number }\end{array}$ & $\begin{array}{c}\text { Sample } \\
\text { Date }\end{array}$ & $\underset{(\mathrm{pCi} / L)^{b}}{u-234}$ & $\underset{(\mathrm{pCi} / \mathrm{L})^{\mathrm{b}}}{\mathrm{U}-235}$ & $\begin{array}{c}U-238 \\
(\mathrm{pCi} / L)^{b}\end{array}$ & $\underset{(\mu g / L)}{v}$ \\
\hline Upper Gunnison & NBD -301 & $06 / 12 / 1995$ & 1.11 & $<0.5$ & 0.73 & $<4.0$ \\
\hline Upper Mid Gunnison & NBD-302 & $06 / 12 / 1995$ & 1.18 & $<0.5$ & 0.67 & $<4.0$ \\
\hline Middle Gunnison & NBD-304 & $06 / 12 / 1995$ & 1.10 & $<0.5$ & 0.73 & $<4.0$ \\
\hline Lower Gunnison & NBD-303 & $06 / 12 / 1995$ & 1.09 & $<0.5$ & 0.67 & $<4.0$ \\
\hline North Pond & NBD-305 & $06 / 12 / 1995$ & 241.49 & 10.96 & 221.68 & -8.0 \\
\hline & NBD-306 & $06 / 12 / 1995$ & 256.20 & 11.05 & 241.90 & $\sim 10.7$ \\
\hline South Pond & NBD -309 & $06 / 13 / 1995$ & 156.67 & 9.02 & 153.86 & $<4.0$ \\
\hline Wetland Area & NBD -308 & $06 / 12 / 1995$ & 184.05 & 8.24 & 181.28 & $<4.0$ \\
\hline
\end{tabular}

$a_{A}$ "<" indicates that the maximum concentration was below the detection limit (number shown is detection 1 imit). A " " indicates an approximate value (the value was outside the limits for which the instrument was calibrated).

The values listed multiplied by $10^{-9}$ will result in units of microcuries per milliliter. 
Table A-3. Groundwater Chemisty Data Collected by Rust At and Near the GJPO During 1995a

\begin{tabular}{|c|c|c|c|c|c|c|c|c|c|c|c|}
\hline $\begin{array}{l}\text { Sample } \\
\text { Location }\end{array}$ & $\begin{array}{l}\text { Ticket } \\
\text { Number }\end{array}$ & $\begin{array}{c}\text { Sample } \\
\text { Date }\end{array}$ & $\begin{array}{l}\text { Alkalinity } \\
\text { (as } \mathrm{CaCO}_{3} \text { ) } \\
\text { (ppm) }\end{array}$ & $\begin{array}{l}\text { Alpha } \\
(\mathrm{pCi} / \mathrm{L})^{\mathrm{b}}\end{array}$ & $\begin{array}{c}\text { As } \\
(\mu g / L)\end{array}$ & $\underset{(\mu \mathrm{ga} / \mathrm{L})}{\mathrm{Ba}}$ & $\underset{(\mathrm{mg} / \mathrm{L})}{\mathbf{C a}}$ & $\underset{(\mu g / L)}{C d}$ & $\begin{array}{c}\operatorname{CDT}^{\mathrm{c}} \\
(\mu \mathrm{mhos} / \mathrm{cm})\end{array}$ & $\underset{(\mathrm{mg} / \mathrm{L})}{\mathrm{Cl}}$ & $\underset{(\mu r / L)}{C r}$ \\
\hline $1-9 S A$ & NBD-314 & $06 / 14 / 1995$ & 258 & $<50$ & $\sim 4.2$ & -18.8 & 104 & $<1.0$ & 1902 & 21.8 & $<4.0$ \\
\hline $10-19 N$ & $\mathrm{NBD}-313$ & $06 / 13 / 1995$ & 390 & 603 & $<3.0$ & $\sim 14.0$ & 319 & $<1.0$ & 5800 & 295 & $<4.0$ \\
\hline $11-12 N A$ & NBD -317 & $06 / 14 / 1995$ & 336 & 156 & 29.3 & $\sim 17.3$ & 242 & $<1.0$ & 2770 & 142 & $<4.0$ \\
\hline $11-15$ & NBD -311 & $06 / 13 / 1995$ & 199 & 179 & $<3.0$ & -15.5 & 74.7 & $<1.0$ & 969 & 7.8 & $<4.0$ \\
\hline $14-13 N A$ & NBD -319 & $06 / 15 / 1995$ & 202 & 407 & $<3.3$ & $\sim 15.5$ & 369 & $<1.0$ & 3900 & 140 & $<4.0$ \\
\hline $14-6 \mathrm{NA}$ & NBD -310 & $06 / 13 / 1995$ & 245 & 133 & 230 & $\sim 46.2$ & 143 & $<1.0$ & 1318 & 11.4 & $<4.0$ \\
\hline $5-12 N A$ & NBD-322 & $06 / 15 / 1995$ & 337 & $<87$ & $<3.0$ & $\sim 16.4$ & 291 & $<1.0$ & 3100 & 154 & $<4.0$ \\
\hline $8-4 S$ & NBD -320 & $06 / 15 / 1995$ & 247 & 359 & $<3.0$ & $\sim 18.0$ & 353 & $<1.0$ & 2820 & 65.9 & $<4.0$ \\
\hline GJB84-04 & $N B D-312$ & $06 / 13 / 1995$ & 246 & 199 & -7.3 & $\sim 12.5$ & 54.1 & $<1.0$ & 1759 & 28.2 & $<4.0$ \\
\hline GJ84-04-Duplicate & NBD -315 & $06 / 13 / 1995$ & No Data & 237 & $\sim 9.4$ & -10.9 & 54.9 & $<1.0$ & No Data & 27.5 & $<4.0$ \\
\hline GJ84-09 & NBD -321 & $06 / 15 / 1995$ & 253 & $<56$ & $<3.0$ & $\sim 17.2$ & 135 & $<1.0$ & 2300 & 56.3 & $<4.0$ \\
\hline GJ84-10 & NBD -318 & $06 / 14 / 1995$ & 210 & $<69$ & $<3.0$ & $\sim 8.7$ & 146 & $<1.0$ & 2730 & 97.6 & $<4.0$ \\
\hline GJ87-15 & NBD - 316 & $06 / 14 / 1995$ & 185 & 303 & 58.9 & $\sim 24.1$ & 369 & $<1.0$ & 6760 & 141 & $<4.0$ \\
\hline
\end{tabular}

$a_{A}$ "<" indicates that the maximum concentration was below the detection limit (number shown is detection limit). A " " indicates an approximate value (the value was outside the limits for which the instrument was calibrated).

The values listed multiplied by $10^{-9}$ will result in units of microcuries per milliliter.

${ }^{c}$ Conductivity in micromhos per centimeter. 
Table A-3 (continued). Groundwater Chemistry Data Collected by Rust At and Near the GJPO During 1995a

\begin{tabular}{|c|c|c|c|c|c|c|c|c|c|c|c|}
\hline $\begin{array}{l}\text { Sample } \\
\text { Location }\end{array}$ & $\begin{array}{l}\text { Ticket } \\
\text { Number }\end{array}$ & $\begin{array}{l}\text { Sample } \\
\text { Date }\end{array}$ & $\begin{array}{c}F e \\
(\mu \mathrm{g} / \mathrm{L})\end{array}$ & $\begin{array}{c}\mathrm{H}_{2} \mathrm{O} \text { Depth } \\
\text { (feet) }\end{array}$ & $\underset{(\mathrm{mg} / \mathrm{L})}{K}$ & $\underset{(\mathrm{mg} / \mathrm{L})}{\mathrm{Mg}}$ & $\underset{(\mu g / L)}{M n}$ & $\begin{array}{c}M o \\
(\mu g / L)\end{array}$ & $\underset{(\mathrm{mg} / \mathrm{L})}{\mathrm{Ma}}$ & $\begin{array}{c}\mathrm{NO}_{3} \\
(\mathrm{mg} / \mathrm{L})\end{array}$ & $\underset{(\mu g / L)}{\mathrm{Pb}}$ \\
\hline $1-9 S A$ & NBD-314 & $06 / 14 / 1995$ & $<5.0$ & 8.72 & 6.1 & 16.4 & 822 & $<17.0$ & 323 & $\sim 0.03$ & $<1.0$ \\
\hline $10-19 \mathrm{~N}$ & NBD-313 & $06 / 13 / 1995$ & 148 & 8.11 & 14.5 & 128 & 3660 & $148^{\circ}$ & 965 & $<0.01$ & $<1.0$ \\
\hline $11-12 N A$ & NBD - 317 & $06 / 14 / 1995$ & $<5.0$ & 2.42 & 9.4 & 77.2 & 802 & $<17.0$ & 335 & 32.2 & $<1.0$ \\
\hline $11-15$ & NBD -311 & $06 / 13 / 1995$ & $<5.0$ & 11.24 & -3.0 & 29.6 & 47.5 & $\sim 28.4$ & 104 & -0.02 & $<1.0$ \\
\hline 14-13NA & NBD -319 & $06 / 15 / 1995$ & $<5.0$ & 1.53 & 18.0 & 76.6 & 4480 & 220 & 506 & $\sim 0.05$ & $<1.0$ \\
\hline 14-6NA & NBD -310 & $06 / 13 / 1995$ & 1640 & 15.05 & 12.8 & 35.6 & 2880 & $<17.0$ & 90.1 & $\sim 0.02$ & $<1.0$ \\
\hline $5-12 N A$ & NBD -322 & $06 / 15 / 1995$ & $<5.0$ & 7.08 & 5.9 & 110 & 508 & $<17.0$ & 332 & 0.46 & $<1.0$ \\
\hline $8-45$ & NBD -320 & $06 / 15 / 1995$ & -46.5 & 6.25 & $\sim 4.8$ & 72.6 & 1660 & 175 & 262 & 16.4 & -1.9 \\
\hline GJ84-04 & NBD -312 & $06 / 13 / 1995$ & $\sim 5.7$ & 3.6 & 5.3 & 14.6 & 642 & 202 & 334 & $<0.01$ & $<1.0$ \\
\hline GJ84-04-Dupl icate & NBD -315 & $06 / 13 / 1995$ & $<5.0$ & No Data & $\sim 4.9$ & 14.6 & 638 & 198 & 337 & $\sim 0.01$ & $<1.0$ \\
\hline GJ384-09 & $N B D-321$ & $06 / 15 / 1995$ & 157 & 10.45 & 7.1 & 22.0 & 225 & $<17.0$ & 386 & $\sim 0.02$ & $<1.0$ \\
\hline G.J84-10 & NBD-318 & $06 / 14 / 1995$ & $<5.0$ & 31.42 & $\sim 4.9$ & 34.2 & 665 & $<17.0$ & 459 & $\sim 0.04$ & $<1.0$ \\
\hline GJ87-15 & $N B D-316$ & $06 / 14 / 1995$ & $<5.0$ & 4.51 & 16.4 & 77.0 & 5510 & 140 & 417 & $\sim 0.01$ & $<1.0$ \\
\hline
\end{tabular}

$a_{A}$ "<" indicates that the maximum concentration was below the detection limit (number shown is detection limit). A " $"$ indicates an approximate value (the value was outside the limits for which the instrument was calibrated). 
Table A-3 (continued). Groundwater Chemistry Data Collected by Rust At and Near the GJPO During 1995a

\begin{tabular}{|c|c|c|c|c|c|c|c|c|c|c|c|}
\hline $\begin{array}{l}\text { Sample } \\
\text { Location }\end{array}$ & $\begin{array}{l}\text { Ticket } \\
\text { Number }\end{array}$ & $\begin{array}{l}\text { Sample } \\
\text { Date }\end{array}$ & pH & $\begin{array}{c}R a-226 \\
(\mathrm{pC} i / L)^{b}\end{array}$ & $\underset{(\mathrm{pCi} / \mathrm{L})^{\mathrm{b}}}{\mathrm{Ra}-228}$ & $\underset{(\mu g / L)}{S e}$ & $\mathrm{SO}_{(\mathrm{mg} / \mathrm{L})}$ & $\underset{(\mathrm{mg} / \mathrm{L})}{\mathrm{TOS}^{\mathrm{C}}}$ & $\begin{array}{c}\text { Temperature } \\
\text { ( } \mathrm{C})\end{array}$ & $\begin{array}{l}\text { Th-230 } \\
(\mathrm{pCi} / \mathrm{L})^{\mathrm{b}}\end{array}$ & $\begin{array}{l}\mathrm{Th}-232 \\
(\mathrm{pCi} / \mathrm{L})^{\mathrm{b}}\end{array}$ \\
\hline $1-9 S A$ & NBD-314 & $06 / 14 / 1995$ & 7.69 & $<0.5$ & $<3.2$ & $<2.0$ & 730 & 1400 & 15.4 & $<1.0$ & $<1.0$ \\
\hline $10-19 N$ & NBD-313 & $06 / 13 / 1995$ & 7.31 & $<0.5$ & $<1.9$ & $<2.0$ & 2640 & 4910 & 14.0 & $<1.0$ & $<1.0$ \\
\hline $11-12 N A$ & NBD-317 & $06 / 14 / 1995$ & 7.00 & $<0.5$ & $<2.6$ & 23.7 & 1030 & 2200 & 14.2 & $<1.0$ & $<1.0$ \\
\hline $11-15$ & NBD-311 & $06 / 13 / 1995$ & 7.55 & $<0.5$ & $<2.5$ & $<10.0$ & 321 & 673 & 12.1 & $<1.0$ & $<1.0$ \\
\hline 14-13NA & NBD-319 & $06 / 15 / 1995$ & 7.34 & $<0.5$ & $<5.3$ & $<2.0$ & 1950 & 3370 & 13.6 & $<1.0$ & $<1.0$ \\
\hline $14-6 N A$ & NBD -310 & $06 / 13 / 1995$ & 7.12 & $<0.5$ & $<3.4$ & $<2.0$ & 478 & 963 & 12.4 & $<1.0$ & $<1.0$ \\
\hline $5-12 N A$ & NBD-322 & $06 / 15 / 1995$ & 7.20 & $<0.5$ & $<2.0$ & $\sim 2.5$ & 1300 & 2610 & 15.0 & $<1.0$ & $<1.0$ \\
\hline $8-45$ & $N B D-320$ & $06 / 15 / 1995$ & 7.06 & $<0.5$ & $<4.1$ & 17.8 & 1360 & 2480 & 13.2 & 5.51 & 8.43 \\
\hline GJ84-04 & NBO -312 & $06 / 13 / 1995$ & 7.43 & $<0.5$ & $<3.9$ & $<2.0$ & 574 & 1220 & 14.0 & $<1.0$ & $<1.0$ \\
\hline GJ84-04-Duplicate & NBD-315 & $06 / 13 / 1995$ & No Data & $<0.5$ & $<2.2$ & $<2.0$ & 571 & 1200 & No Data & $<1.0$ & $<1.0$ \\
\hline GJ84-09 & NBD-321 & $06 / 15 / 1995$ & 7.56 & $<0.5$ & $<3.0$ & $<2.0$ & 905 & 1680 & 14.8 & $<1.0$ & $<1.0$ \\
\hline GJ84-10 & NBD -318 & $06 / 14 / 1995$ & 7.44 & $<0.5$ & $<2.0$ & $<2.0$ & 1140 & 2060 & 15.3 & $<1.0$ & $<1.0$ \\
\hline GJ87-15 & $N B D-316$ & $06 / 14 / 1995$ & 6.76 & $<0.5$ & $<1.5$ & $<2.0$ & 1720 & 2980 & 14.8 & $<1.0$ & $<1.0$ \\
\hline
\end{tabular}

aA "<" indicates that the maximum concentration was below the detection limit (number shown is detection limit). A " $"$ indicates an approximate value (the value was outside the limits for which the instrument was calibrated).

b The values 1 isted multiplied by $10^{-9}$ will result in units of microcuries per milliliter.

cTotal dissolved solids. 
Table A-3 (continued). Groundwater Chemistry Data Collected by Rust At and Near the GJPO During 1995a

\begin{tabular}{|c|c|c|c|c|c|c|c|}
\hline $\begin{array}{l}\text { Sample } \\
\text { Location }\end{array}$ & $\begin{array}{l}\text { Ticket } \\
\text { Number }\end{array}$ & $\begin{array}{l}\text { Sample } \\
\text { Date }\end{array}$ & $\underset{(\mathrm{mg} / \mathrm{L})}{\mathrm{TOC}^{\mathrm{b}}}$ & $\begin{array}{c}\mathrm{U}-234 \\
(\mathrm{pCi} / \mathrm{L})^{\mathrm{c}}\end{array}$ & $\begin{array}{c}\mathrm{U}-235 \\
(\mathrm{pCi} / \mathrm{L})^{\mathrm{c}}\end{array}$ & $\begin{array}{c}U-238 \\
(\mathrm{pCi} / \mathrm{L})^{\mathrm{c}}\end{array}$ & $\underset{(\mu \mathrm{g} / L)}{V}$ \\
\hline $1-9 S A$ & NBD-314 & $06 / 14 / 1995$ & 8.9 & 9.45 & 0.31 & 6.51 & $<4.0$ \\
\hline $10-19 N$ & $N B D-313$ & $06 / 13 / 1995$ & 20.5 & 246.48 & 10.75 & 240.61 & $<4.0$ \\
\hline $11-12 \mathrm{NA}$ & NBD-317 & $06 / 14 / 1995$ & 14.8 & 117.95 & 4.97 & 108.04 & 146 \\
\hline $11-15$ & NBD-311 & $06 / 13 / 1995$ & 8.4 & 67.07 & 3.26 & 66.54 & $<4.0$ \\
\hline $14-13 N A$ & $N B D-319$ & $06 / 15 / 1995$ & 11.1 & 158.09 & 6.49 & 155.42 & $\sim 13.3$ \\
\hline $14-6 \mathrm{NA}$ & NBD-310 & $06 / 13 / 1995$ & 11.1 & 54.46 & 2.59 & 55.54 & $\sim 4.0$ \\
\hline $5-12 N A$ & NBD-322 & $06 / 15 / 1995$ & 8.0 & 26.51 . & 0.66 & 17.02 & $<4.0$ \\
\hline $8-4 S$ & $N B D-320$ & $06 / 15 / 1995$ & 12.3 & 198.15 & 7.76 & 190.03 & $\sim 6.7$ \\
\hline GJ84-04 & NBD-312 & $06 / 13 / 1995$ & 12.9 & 104.66 & 4.66 & 107.05 & $\sim 19.4$ \\
\hline GJ84-04-Dupl icate & NBD-315 & $06 / 13 / 1995$ & 10.9 & 105.78 & 5.17 & 102.82 & $\sim 11.6$ \\
\hline GJ84-09 & $N B D-321$ & $06 / 15 / 1995$ & 8.3 & 6.56 & 0.54 & 3.82 & $<4.0$ \\
\hline GJ384-10 & $N B D-318$ & $06 / 14 / 1995$ & 7.4 & 7.34 & 0.53 & 3.53 & $<4.0$ \\
\hline GJ $87-15$ & NBD -316 & $06 / 14 / 1995$ & 9.4 & 94.91 & 4.47 & 93.82 & 139 \\
\hline
\end{tabular}

$a_{A}$ " $<"$ indicates that the maximum concentration was below the detection limit (number shown is detection limit). A " " indicates an approximate value (the value was outside the limits for which the instrument was calibrated).

Total organic carbon.

${ }^{c}$ The values listed multiplied by $10^{-9}$ will result in units of microcuries per milliliter. 
Table A-4. QA/QC Chemistry Data Collected by Rust At and Near the GJPO During 1995a

\begin{tabular}{|c|c|c|c|c|c|c|c|c|c|c|c|}
\hline $\begin{array}{c}\text { Sample } \\
\text { Location }\end{array}$ & $\begin{array}{l}\text { Ticket } \\
\text { Number }\end{array}$ & $\begin{array}{l}\text { Sample } \\
\text { Date }\end{array}$ & $\begin{array}{l}\text { Alpha } \\
(\mathrm{pCi} i / L)^{b}\end{array}$ & $\underset{(\mu \mathrm{g} / \mathrm{L})}{\text { As }}$ & $\begin{array}{c}\mathrm{Ba} \\
(\mu \mathrm{gg} / \mathrm{L})\end{array}$ & $\underset{(\mathrm{mg} / \mathrm{L})}{\mathrm{Ca}}$ & $\underset{(\mu g / L)}{C d}$ & $\begin{array}{c}\mathrm{Cl} \\
(\mathrm{mg} / \mathrm{L})\end{array}$ & $\begin{array}{c}C r \\
(\mu g / L)\end{array}$ & $\begin{array}{c}\mathrm{Fe} \\
(\mu g / L)\end{array}$ & $\underset{(m g / L)}{K}$ \\
\hline \multirow[t]{5}{*}{ Equipment Blank } & NBD-307 & $06 / 12 / 1995$ & $<7.3$ & $<3.0$ & $\sim 2.1$ & $\sim 0.06$ & $<1.0$ & $<0.01$ & $<4.0$ & $<5.0$ & $<1.0$ \\
\hline & & & $\underset{(\mathrm{mg} / \mathrm{L})}{\mathrm{Mg}}$ & $\underset{(\mu \mathrm{gn} / \mathrm{L})}{\mathrm{Mn}}$ & $\underset{(\mu \rho g / L)}{M o}$ & $\underset{(\mathrm{mg} / \mathrm{L})}{\mathrm{Na}}$ & $\begin{array}{l}\mathrm{NO}_{3} \\
(\mathrm{mg} / \mathrm{L})\end{array}$ & $\underset{(\mu \mathrm{g} / \mathrm{L})}{\mathrm{Pb}}$ & $\begin{array}{c}R a-226 \\
(\mathrm{pCi} / \mathrm{L})^{\mathrm{b}}\end{array}$ & $\begin{array}{c}\mathrm{Ra}-228 \\
(\mathrm{pC} i / L)^{b}\end{array}$ & $\underset{(\mu g / L)}{S e}$ \\
\hline & & & $<0.05$ & $\sim 1.6$ & $<17.0$ & $\sim 0.29$ & $\sim 0.01$ & $\sim 1.3$ & $<0.5$ & $<2.0$ & $<2.0$ \\
\hline & & & $\begin{array}{c}\mathrm{SO}_{4} \\
(\mathrm{mg} / \mathrm{L})\end{array}$ & $\underset{(\mathrm{mg} / \mathrm{L})}{\mathrm{TDS}^{\mathrm{C}}}$ & $\begin{array}{c}\mathrm{Th}-230 \\
(\mathrm{pCi} / L)^{b}\end{array}$ & $\begin{array}{c}\text { Th-232 } \\
\text { (pCi/L) }\end{array}$ & $\underset{(\mathrm{mg} / \mathrm{L})}{\mathrm{TOC}^{\mathrm{d}}}$ & $\begin{array}{c}U-234 \\
(\mathrm{pCi} / L)^{b}\end{array}$ & $\underset{(\mathrm{pCi} / \mathrm{L})^{\mathrm{b}}}{\mathrm{U}-235}$ & $\underset{(p C i / L)^{b}}{U-238}$ & $\underset{(\mu \operatorname{sg} / L)}{v}$ \\
\hline & & & $\sim 0.05$ & $\sim 13.0$ & $<1.0$ & $<1.0$ & 0.42 & $<0.5$ & $<0.5$ & $<0.5$ & $<4.0$ \\
\hline
\end{tabular}

$a_{A}$ "<" indicates that the maximum concentration was below the detection limit (number shown is detection limit). $A$ " $"$ indicates an approximate value (the value was outside the limits for which the instrument was calibrated).

b The values listed multiplied by $10^{-9}$ will result in units of microcuries per milliliter.

CTotal dissolved solids.

dotal organic carbon. 


\begin{tabular}{|c|c|c|c|c|c|c|c|c|c|c|c|c|}
\hline $\begin{array}{ll}0 & 0 \\
0 & 0 \\
0 & 0 \\
2 & 0 \\
1 & 0\end{array}$ & Table $A$ & $\begin{array}{l}\text { Ground } \\
\text { During }\end{array}$ & $\begin{array}{l}\text { ater } C \\
95 a\end{array}$ & nistry & a Coll & d by $C$ & Ridge & ationa & Laborato & At an & Near $G J$ & \\
\hline 苗 & $\begin{array}{l}\text { Sample } \\
\text { Location }\end{array}$ & $\begin{array}{c}\text { Sample } \\
\text { Date }\end{array}$ & $\underset{(\mathrm{mg} / \mathrm{L})}{\mathrm{Ag}}$ & $\underset{(\mathrm{mg} / \mathrm{L})}{\mathrm{A})}$ & $\begin{array}{c}\text { As } \\
(\mathrm{mg} / \mathrm{L})\end{array}$ & $\underset{(\mathrm{mg} / \mathrm{L})}{\mathrm{B}}$ & $\begin{array}{c}\mathrm{Ba} \\
(\mathrm{mg} / \mathrm{L})\end{array}$ & $\underset{(\mathrm{mg} / \mathrm{L})}{\mathrm{Be}}$ & $\underset{(\mathrm{mg} / \mathrm{L})}{\mathrm{Ca}}$ & $\underset{(m g / L)}{c d}$ & $\underset{(m g / L)}{C 1}$ & $\begin{array}{c}\text { Co } \\
(\mathrm{mg} / \mathrm{L})\end{array}$ \\
\hline 7 & $11-1 \mathrm{~s}$ & $01 / 09 / 1995$ & $<.005$ & $<.05$ & $<.01$ & No Data & .036 & $<.001$ & 160 & $<.005$ & 63.9 & $<.004$ \\
\hline$\underline{B}$ & & $07 / 13 / 1995$ & $<.005$ & $<.05$ & $<.01$ & .13 & .019 & $<.001$ & 86 & $<.005$ & No Data & .0046 \\
\hline$\vec{E}$ & & $10 / 20 / 1995$ & $<.005$ & $<.05$ & $<.01$ & .49 & .038 & $<.001$ & 270 & $<.005$ & No Data & $<.004$ \\
\hline$\pi$ & 14-6NA & $01 / 05 / 1995$ & $<.005$ & $<.05$ & .31 & No Data & .057 & $<.001$ & 190 & $<.005$ & 47.4 & $<.004$ \\
\hline & & $07 / 11 / 1995$ & $<.005$ & $<.05$ & .17 & .15 & .044 & $<.001$ & 140 & $<.005$ & No Data & $<.004$ \\
\hline & & $10 / 19 / 1995$ & $<.005$ & $<.05$ & .28 & .35 & .079 & $<.001$ & 250 & $<.005$ & No Data & $<.004$ \\
\hline & $8-4 S$ & $10 / 20 / 1995$ & $<.005$ & $<.05$ & $<.01$ & .65 & .019 & $<.001$ & 310 & $<.005$ & No Data & $<.004$ \\
\hline & GJ84-04 & $01 / 09 / 1995$ & $<.005$ & $<.05$ & .01 & No Data & .029 & $<.001$ & 310 & $<.005$ & 164 & $<.004$ \\
\hline & GJ84-04-Duplicate & $01 / 09 / 1995$ & $<.005$ & $<.05$ & .01 & No Data & .028 & $<.001$ & 310 & $<.005$ & 165 & $<.004$ \\
\hline & & $07 / 11 / 1995$ & $<.005$ & $<.05$ & .011 & .35 & .017 & $<.001$ & 27 & $<.005$ & No Data & $<.004$ \\
\hline & & $10 / 19 / 1995$ & .0056 & $<.05$ & $<.01$ & .64 & .038 & $<.001$ & 270 & $<.005$ & No Data & $<.004$ \\
\hline & GJ84-05 & $01 / 09 / 1995$ & $<.005$ & $<.05$ & $<.001$ & No Data & .021 & $<.001$ & 320 & $<.005$ & 237 & $<.004$ \\
\hline & GJ94-01 & $01 / 03 / 1995$ & $<.005$ & $<.05$ & $<.01$ & No Data & .027 & $<.001$ & 310 & $<.005$ & No Data & $<.004$ \\
\hline & & $01 / 10 / 1995$ & No Data & No Data & No Data & No Data & No Data & No Data & No Data & No Data & 367 & No Data \\
\hline & & $07 / 10 / 1995$ & $<.005$ & $<.05$ & $<.01$ & .83 & .018 & $<.001$ & 64 & $<.005$ & No Data & $<.004$ \\
\hline & , & $10 / 17 / 1995$ & $<.005$ & $<.05$ & $<.01$ & 1.5 & .037 & $<.001$ & 370 & $<.005$ & No Data & $<.004$ \\
\hline & GJ94-02 & $01 / 03 / 1995$ & .006 & $<.05$ & $<.01$ & No Data & .021 & $<.001$ & 530 & $<.005$ & 164 & $<.004$ \\
\hline & & $04 / 12 / 1995$ & $<.005$ & $<.05$ & $<.01$ & No Data & .019 & $<.001$ & 540 & $<.005$ & No Data & .0042 \\
\hline & & $07 / 10 / 1995$ & $<.005$ & .15 & $<.01$ & .71 & .015 & $<.001$ & 190 & $<.005$ & No Data & $<.004$ \\
\hline & & $10 / 17 / 1995$ & $<.01$ & $<.05$ & $<.01$ & 1 & .021 & $<.001$ & 470 & $<.005$ & No Data & $<.004$ \\
\hline & GJ94-03 & $01 / 04 / 1995$ & $<.005$ & $<.05$ & $<.01$ & No Data & .026 & $<.001$ & 420 & $<.005$ & 442 & $<.004$ \\
\hline$t$ & & $04 / 12 / 1995$ & $<.005$ & $<.05$ & $<.01$ & No Data & .025 & $<.001$ & 400 & $<.005$ & No Data & $<.004$ \\
\hline & & $07 / 11 / 1995$ & $<.005$ & $<.05$ & $<.01$ & .48 & .018 & $<.001$ & 310 & $<.005$ & No Data & .0045 \\
\hline & & $10 / 17 / 1995$ & $<.005$ & $<.05$ & $<.01$ &. .55 & .029 & $<.001$ & 320 & $<.005$ & No Data & $<.004$ \\
\hline ఏ & GJ94-04 & $01 / 04 / 1995$ & $<.005$ & $<.05$ & .014 & No Data & .022 & $<.001$ & 130 & $<.005$ & 29 & $<.004$ \\
\hline t & & $04 / 10 / 1995$ & $<.005$ & .066 & $<.01$ & No Data & .022 & $<.001$ & 130 & $<.005$ & No Data & $<.004$ \\
\hline 豆 & & $07 / 12 / 1995$ & $<.005$ & $<.05$ & $<.01$ & .25 & .014 & $<.001$ & 93 & $<.005$ & No Data & $<.004$ \\
\hline
\end{tabular}

$a_{A}$ "<" symbol indicates that the maximum concentration was below the detection limit (number shown is detection limit). 


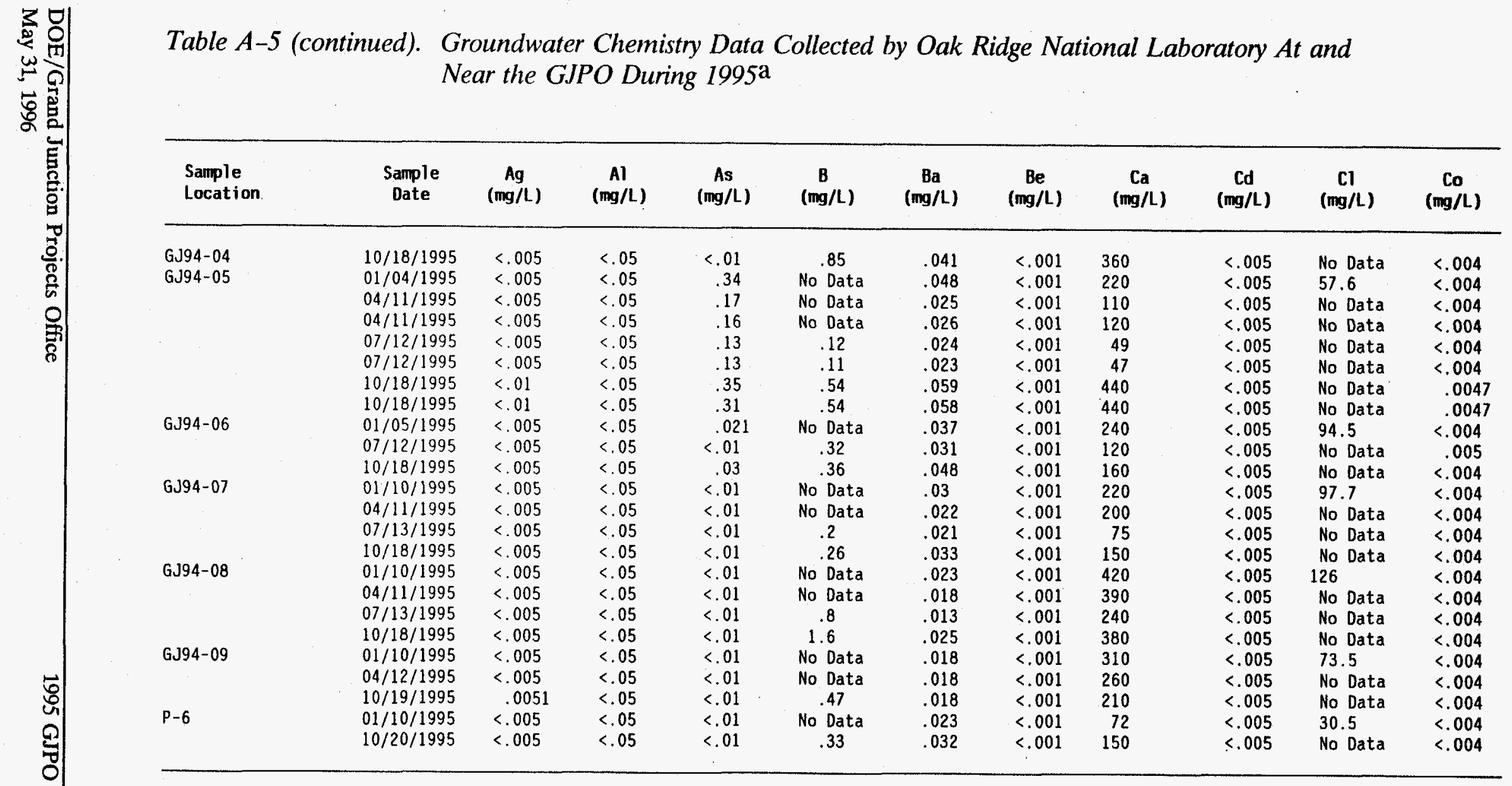

$a_{A}$ " $<"$ symbol indicates that the maximum concentration was below the detection limit (number shown is detection limit). 


\begin{tabular}{|c|c|c|c|c|c|c|c|c|c|c|c|c|}
\hline $\begin{array}{ll}0 & 0 \\
0 & 0 \\
> & 0 \\
& 0\end{array}$ & \multicolumn{12}{|c|}{ Table A-5 (continued). } \\
\hline $\begin{array}{l}\text { Th } \\
\text { ga } \\
\text { s. }\end{array}$ & $\begin{array}{l}\text { Sample } \\
\text { Location }\end{array}$ & $\begin{array}{c}\text { Sample } \\
\text { Date }\end{array}$ & $\underset{(\mathrm{mg} / \mathrm{L})}{\mathrm{Cr}}$ & $\underset{(m g / L)}{\mathrm{Cu}}$ & $\begin{array}{c}F e \\
(\mathrm{mg} / \mathrm{L})\end{array}$ & $\underset{(\mathrm{mg} / \mathrm{L})}{\mathrm{Hg}}$ & $\underset{(m g / L)}{K}$ & $\underset{(\mathrm{mg} / \mathrm{L})}{\mathrm{Mg}}$ & $\underset{(m g / L)}{M n}$ & $\begin{array}{c}\text { Mo } \\
\text { (mg/L) }\end{array}$ & $\underset{(\mathrm{mg} / \mathrm{L})}{\mathrm{Ma}}$ & $\underset{(\mathrm{mg} / \mathrm{L})}{\mathrm{Ni}}$ \\
\hline & \multirow[t]{3}{*}{$11-1 \mathrm{~s}$} & $01 / 09 / 1995$ & $<.004$ & $<.007$ & $<.05$ & .00012 & 8.9 & 69 & .06 & .24 & 350 & $<.01$ \\
\hline & & $07 / 13 / 1995$ & $<.004$ & $<.007$ & $<.05$ & $<.00005$ & 4.9 & 33 & .081 & .052 & 86 & $<.01$ \\
\hline 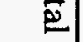 & & $10 / 20 / 1995$ & $<.004$ & $<.007$ & $<.05$ & $<.00005$ & 8.9 & 110 & .094 & .14 & $<370$ & $<.01$ \\
\hline$\varnothing$ & \multirow{3}{*}{$14-6 N A$} & $01 / 05 / 1995$ & $<.004$ & $<.007$ & 2.8 & .0001 & 20 & 40 & 5.1 & $<.04$ & 180 & $<.01$ \\
\hline 8 & & $07 / 11 / 1995$ & $<.004$ & $<.007$ & 1.3 & $<.00005$ & 13 & 35 & 2.1 & $<.04$ & 93 & $<.01$ \\
\hline & & $10 / 19 / 1995$ & $<.004$ & $<.007$ & 2.8 & $<.00005$ & 21 & 52 & 6.3 & $<.04$ & 200 & .012 \\
\hline & $8-45$ & $10 / 20 / 1995$ & $<.004$ & $<.007$ & .083 & $<.00005$ & 7.8 & 91 & .97 & .14 & 250 & .012 \\
\hline & GJ84-04 & $01 / 09 / 1995$ & $<.004$ & $<.007$ & $<.05$ & .00011 & 15 & 80 & 4.2 & .21 & 810 & $<.01$ \\
\hline & \multirow{3}{*}{ G.J84-04-Duplicate } & $01 / 09 / 1995$ & $<.004$ & $<.007$ & $<.05$ & .00014 & 16 & 79 & 4 & .21 & 770 & $<.01$ \\
\hline & & $07 / 11 / 1995$ & $<.004$ & .0077 & $<.05$ & $<.00005$ & 4.1 & 6.9 & .25 & .24 & 210 & $<.01$ \\
\hline & & $10 / 19 / 1995$ & $<.004$ & $<.007$ & $<.05$ & .00005 & 13 & 67 & 3.4 & .18 & 640 & $<.01$ \\
\hline & GJ84-05 & $01 / 09 / 1995$ & $<.004$ & $<.007$ & $<.05$ & .00014 & 10 & 120 & 1.2 & .16 & 380 & $<.01$ \\
\hline & \multirow[t]{3}{*}{ GJ94-01 } & $01 / 03 / 1995$ & $<.004$ & $<.007$ & 2.1 & .00012 & No Data & 170 & 4.6 & $<.04$ & 930 & $<.01$ \\
\hline & & $\begin{array}{l}01 / 10 / 1995 \\
07 / 10 / 1995\end{array}$ & $\begin{array}{c}\text { No Data } \\
<.004\end{array}$ & $\begin{array}{l}\text { No Data } \\
<.007\end{array}$ & $\begin{array}{c}\text { No Data } \\
.41\end{array}$ & $\begin{array}{l}\text { No Data } \\
<.00005\end{array}$ & $\begin{array}{l}\text { No Data } \\
7.2\end{array}$ & $\begin{array}{l}\text { No Data } \\
36\end{array}$ & $\begin{array}{c}\text { No Data } \\
.84\end{array}$ & $\begin{array}{c}\text { No Data } \\
.051\end{array}$ & $\begin{array}{l}\text { No Data } \\
320\end{array}$ & $\begin{array}{l}\text { No Data } \\
<.01\end{array}$ \\
\hline & & $10 / 17 / 1995$ & $<.004$ & $<.007$ & 2.6 & $<.00005$ & $20^{\circ}$ & 200 & 3.7 & $<.04$ & 940 & $<.01$ \\
\hline & \multirow[t]{4}{*}{ GJ94-02 } & $01 / 03 / 1995$ & $<.004$ & $<.007$ & .74 & .00012 & No Data & 130 & 4.7 & .17 & 1100 & .01 \\
\hline & & $04 / 12 / 1995$ & $<.004$ & $<.007$ & .92 & $<.00005$ & 17 & 150 & 5.5 & .21 & 1100 & $<.01$ \\
\hline & & $07 / 10 / 1995$ & $<.004$ & .0071 & .35 & $<.00005$ & 9.6 & 51 & 1.9 & .19 & 560 & $<.01$ \\
\hline & & $10 / 17 / 1995$ & $<.004$ & .011 & .48 & .00006 & 11 & 93 & 2.9 & .16 & 820 & $<.01$ \\
\hline & \multirow{4}{*}{ GJ94-03 } & $01 / 04 / 1995$ & $<.004$ & $<.007$ & .23 & .00012 & No Data & 73 & 5.1 & .16 & 540 & $<.01$ \\
\hline & & $04 / 12 / 1995$ & $<.004$ & $<.007$ & .36 & $<.00005$ & 12 & 68 & 5.3 & .13 & 480 & $<.01$ \\
\hline$\overline{0}$ & & $07 / 11 / 1995$ & $<.004$ & $<.007$ & .3 & $<.00005$ & 10 & 55 & 3.7 & .11 & 380 & $<.01$ \\
\hline & & $10 / 17 / 1995$ & $<.004$ & $<.007$ & 1.9 & .00006 & 11 & 53 & 4.2 & .1 & 360 & $<.01$ \\
\hline a) & \multirow[t]{3}{*}{ GJ94-04 } & $01 / 04 / 1995$ & $<.004$ & $<.007$ & .16 & .00012 & No Data & 23 & 1.6 & .052 & 230 & $<.01$ \\
\hline 2 & & $04 / 10 / 1995$ & $<.004$ & $<.007$ & .18 & $<.00005$ & 4.8 & 21 & 1.3 & .043 & 250 & $<.01$ \\
\hline 豆 & & $07 / 12 / 1995$ & $<.004$ & $<.007$ & .094 & $<.00005$ & 4.9 & 14 & .98 & $<.04$ & 200 & $<.01$ \\
\hline
\end{tabular}

$a_{A} "<"$ symbol indicates that the maximum concentration was below the detection limit (number shown is detection limit). 


\begin{tabular}{|c|c|c|c|c|c|c|c|c|c|c|c|c|}
\hline 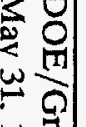 & Table $A-$ & (ed). $\begin{array}{l}G \\
N\end{array}$ & $\begin{array}{l}\text { undwo } \\
r \text { the }\end{array}$ & $\begin{array}{l}\text { Chem } \\
\text { O Du }\end{array}$ & $\begin{array}{l}\text { Dato } \\
1995\end{array}$ & lected & Oak & dge $\mathrm{Na}$ & al $L$ & tory & and & \\
\hline 를. & $\begin{array}{l}\text { Sample } \\
\text { Location }\end{array}$ & $\begin{array}{l}\text { Sample } \\
\text { Date }\end{array}$ & $\underset{(m g / L)}{\mathrm{Cr}}$ & $\underset{(\mathrm{mg} / \mathrm{L})}{\mathrm{Cu}}$ & $\underset{(\mathrm{mg} / \mathrm{L})}{\mathrm{Fe}}$ & $\underset{(m g / L)}{H g}$ & $\underset{(m g / L)}{K}$ & $\underset{(\mathrm{mg} / \mathrm{L})}{\mathrm{Mg}}$ & $\underset{(m g / L)}{M n}$ & $\begin{array}{c}\text { Mo } \\
\text { (mg/L) }\end{array}$ & $\underset{(m g / L)}{\mathrm{Ma}}$ & $\underset{(\mathrm{mg} / \mathrm{L})}{\mathrm{Ni}}$ \\
\hline 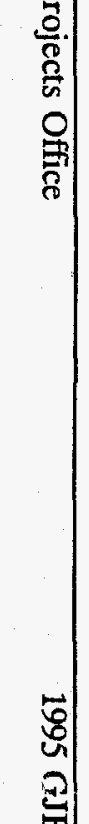 & $\begin{array}{l}\text { GJ94-08 } \\
\text { GJ94-09 } \\
\text { P-6 }\end{array}$ & $\begin{array}{l}10 / 18 / 1995 \\
01 / 04 / 1995 \\
04 / 11 / 1995 \\
04 / 11 / 1995 \\
07 / 12 / 1995 \\
07 / 12 / 1995 \\
10 / 18 / 1995 \\
10 / 18 / 1995 \\
01 / 05 / 1995 \\
07 / 12 / 1995 \\
10 / 18 / 1995 \\
01 / 10 / 1995 \\
04 / 11 / 1995 \\
07 / 13 / 1995 \\
10 / 18 / 1995 \\
01 / 10 / 1995 \\
04 / 11 / 1995 \\
07 / 13 / 1995 \\
10 / 18 / 1995 \\
01 / 10 / 1995 \\
04 / 12 / 1995 \\
10 / 19 / 1995 \\
01 / 10 / 1995 \\
10 / 20 / 1995\end{array}$ & $\begin{array}{l}<.004 \\
<.004 \\
<.004 \\
<.004 \\
<.004 \\
<.004 \\
<.004 \\
<.004 \\
<.004 \\
<.004 \\
<.004 \\
<.004 \\
<.004 \\
<.004 \\
<.004 \\
<.004 \\
<.004 \\
<.004 \\
<.004 \\
<.004 \\
<.004 \\
<.004 \\
<.004 \\
<.004\end{array}$ & $\begin{array}{l}<.007 \\
<.007 \\
<.007 \\
<.007 \\
<.007 \\
<.007 \\
<.007 \\
<.007 \\
<.007 \\
<.007 \\
<.007 \\
<.007 \\
<.007 \\
<.007 \\
<.007 \\
<.007 \\
<.007 \\
<.007 \\
<.007 \\
<.007 \\
<.007 \\
<.007 \\
<.007 \\
<.007\end{array}$ & $\begin{array}{l}.29 \\
.36 \\
.38 \\
.15 \\
.14 \\
1.7 \\
1.7 \\
3.1 \\
2.7 \\
2.6 \\
<.05 \\
<.05 \\
<.05 \\
.092 \\
.16 \\
.053 \\
<.05 \\
<.05 \\
.19 \\
.13 \\
.078 \\
<.05 \\
<.05\end{array}$ & $\begin{array}{r}.00005 \\
.00013 \\
<.00005 \\
<.00005 \\
<.00005 \\
<.00005 \\
.00005 \\
<.00005 \\
.00012 \\
<.00005 \\
.00005 \\
.00015 \\
<.00005 \\
<.00005 \\
<.00005 \\
.00014 \\
<.00005 \\
<.00005 \\
<.00005 \\
.00014 \\
<.00005 \\
<.00005 \\
.00011 \\
.00005\end{array}$ & $\begin{array}{l}12 \\
\text { No Data } \\
12 \\
11 \\
6.8 \\
7.1 \\
26 \\
27 \\
16 \\
11 \\
14 \\
14 \\
12 \\
7 \\
9.7 \\
12 \\
9.4 \\
7.2 \\
9.5 \\
11 \\
8.7 \\
8.4 \\
6.7 \\
8\end{array}$ & $\begin{array}{c}64 \\
37 \\
20 \\
21 \\
8.6 \\
8.4 \\
69 \\
69 \\
46 \\
27 \\
33 \\
54 \\
52 \\
18 \\
37 \\
100 \\
96 \\
59 \\
100 \\
59 \\
54 \\
42 \\
13 \\
27\end{array}$ & $\begin{array}{l}4 \\
5.5 \\
2.6 \\
2.7 \\
1 \\
1 \\
9.1 \\
9 \\
2.9 \\
1.8 \\
2.2 \\
2.3 \\
1.1 \\
.62 \\
1.1 \\
1.1 \\
.59 \\
.19 \\
.13 \\
1.6 \\
1.2 \\
.9 \\
.5 \\
.75\end{array}$ & $\begin{array}{l}.089 \\
.055 \\
<.04 \\
<.04 \\
<.04 \\
<.04 \\
.052 \\
.049 \\
.11 \\
.092 \\
.095 \\
.64 \\
.55 \\
.46 \\
.58 \\
.12 \\
.14 \\
.25 \\
.19 \\
.13 \\
.12 \\
.2 \\
<.04 \\
<.04\end{array}$ & $\begin{array}{r}370 \\
230 \\
120 \\
120 \\
79 \\
76 \\
300 \\
<300 \\
320 \\
210 \\
240 \\
310 \\
280 \\
160 \\
210 \\
370 \\
320 \\
310 \\
370 \\
350 \\
330 \\
300 \\
290 \\
350\end{array}$ & $\begin{array}{l}<.01 \\
<.01 \\
<.01 \\
<.01 \\
<.01 \\
<.01 \\
<.01 \\
.012 \\
<.01 \\
<.01 \\
<.01 \\
<.01 \\
<.01 \\
<.01 \\
<.01 \\
<.01 \\
.013 \\
<.01 \\
.017 \\
<.01 \\
<.01 \\
<.01 \\
<.01 \\
<.01\end{array}$ \\
\hline
\end{tabular}

$a_{A}$ "c" symbol indicates that the maximum concentration was below the detection limit (number shown is detection limit). 


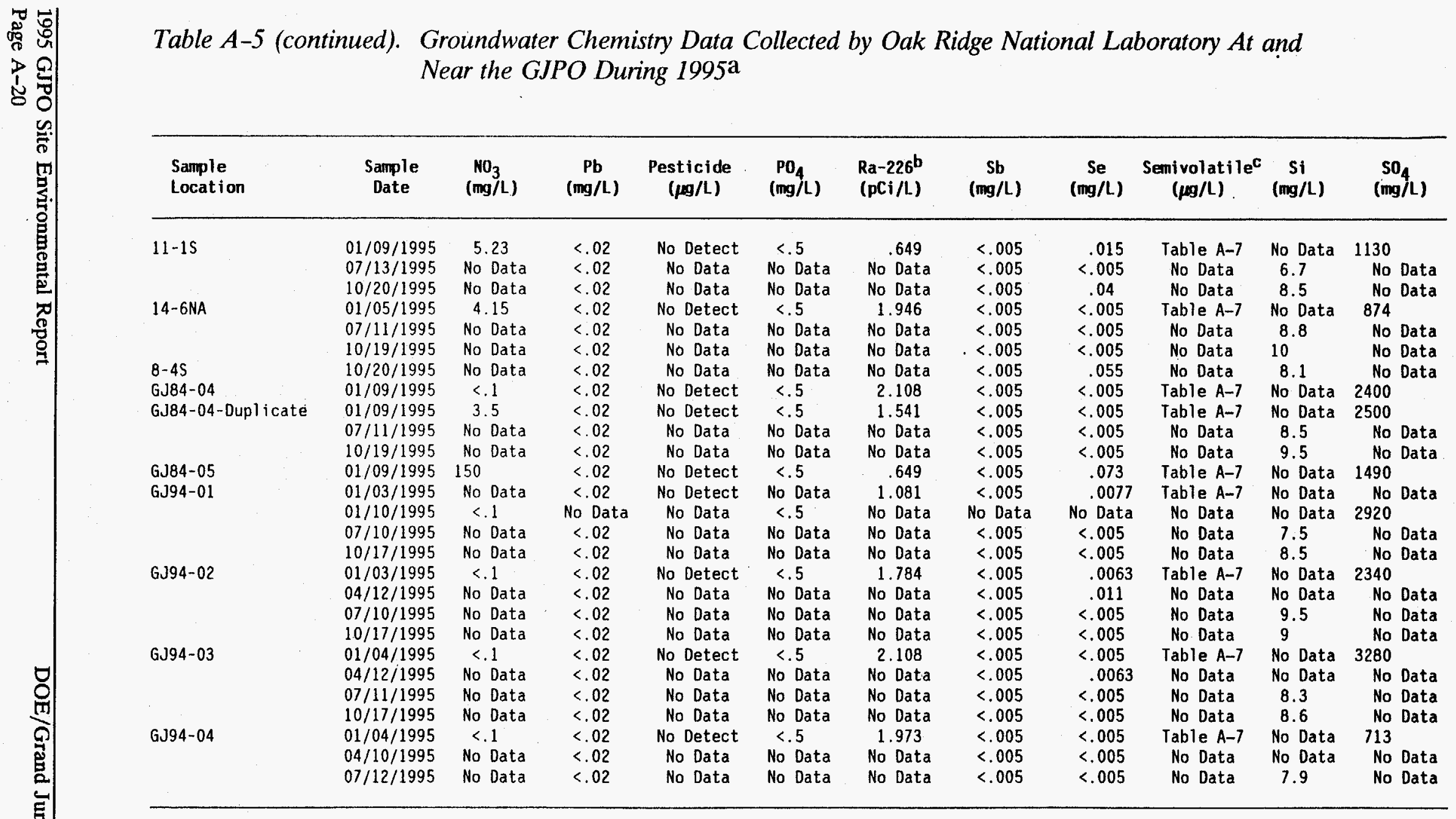

$a_{A}$ "<" symbol indicates that the maximum concentration was below the detection limit (number shown is detection 1 imit).

Radium-226 activities were measured in bequerels per $1 \mathrm{iter}$ and the results were converted to picocuries per 1 iter for reporting purposes. The values listed multiplied by $10^{-9}$ will result in units of microcuries per milliliter.

Refer to Table A-7 for a list of detected constituents. 
Table A-5 (continued). Groundwater Chemistry Data Collected by Oak Ridge National Laboratory At and Near the GJPO During $1995^{5}$

\begin{tabular}{|c|c|c|c|c|c|c|c|c|c|c|c|}
\hline $\begin{array}{l}\text { Sample } \\
\text { Location }\end{array}$ & $\begin{array}{l}\text { Sample } \\
\text { Date }\end{array}$ & $\stackrel{\mathrm{M0}_{3}}{(\mathrm{mg} / \mathrm{L})}$ & $\begin{array}{c}\mathrm{Pb} \\
(\mathrm{mg} / \mathrm{L})\end{array}$ & $\begin{array}{l}\text { Pesticide } \\
(\mu \mathrm{L} / \mathrm{L})\end{array}$ & $\begin{array}{l}\mathrm{PO}_{4} \\
(\mathrm{mg} / \mathrm{L})\end{array}$ & $\begin{array}{l}\mathrm{Ra}-226^{\mathrm{b}} \\
(\mathrm{pCi} / \mathrm{L})\end{array}$ & $\begin{array}{c}\text { Sb } \\
(m g / L)\end{array}$ & $\underset{(\mathrm{mg} / \mathrm{L})}{\mathrm{Se}}$ & $\underset{(\mu \mathrm{g} / \mathrm{L})}{\text { Semivolatilec }}$ & $\underset{(\mathrm{mg} / \mathrm{L})}{\mathrm{Si}}$ & $\underset{(\mathrm{mg} / \mathrm{L})}{\mathrm{SO}_{4}}$ \\
\hline \multirow[t]{7}{*}{$\begin{array}{l}\text { GJ94-04 } \\
\text { GJ94-05 }\end{array}$} & $\begin{array}{l}10 / 18 / 1995 \\
01 / 04 / 1995\end{array}$ & $\begin{array}{l}\text { No Data } \\
<.1\end{array}$ & $\begin{array}{l}<.02 \\
<.02\end{array}$ & $\begin{array}{l}\text { No Data } \\
\text { No Detect }\end{array}$ & $\begin{array}{l}\text { No Data } \\
<.5\end{array}$ & $\begin{array}{l}\text { No Data } \\
2.405\end{array}$ & $\begin{array}{l}<.005 \\
<.005\end{array}$ & $\begin{array}{l}<.005 \\
<.005\end{array}$ & $\begin{array}{l}\text { No Data } \\
\text { Table A-7 }\end{array}$ & $\begin{array}{l}8.8 \\
\text { No Data }\end{array}$ & $\begin{array}{l}\text { No Data } \\
1030\end{array}$ \\
\hline & $04 / 11 / 1995$ & No Data & $<.02$ & No Data & No Data & No Data & $<.005$ & $<.005$ & No Data & No Data & No Data \\
\hline & $04 / 11 / 1995$ & No Data & $<.02$ & No Data & No Data & No Data & $<.005$ & $<.005$ & No Data & No Data & No Data \\
\hline & $07 / 12 / 1995$ & No Data & $<.02$ & No Data & No Data & No Data & $<.005$ & $<.005$ & No Data & 7.2 & No Data \\
\hline & $07 / 12 / 1995$ & No Data & $<.02$ & No Data & No Data & No Data & $<.005$ & $<.005$ & No Datá & 7 & No Data \\
\hline & $10 / 18 / 1995$ & No Data & $<.02$ & No Data & No Data & No Data & $<.005$ & $<.005$ & No Data & 9 & No Data \\
\hline & $10 / 18 / 1995$ & No Data & $<.02$ & No Data & No Data & No Data & $<.005$ & $<.005$ & No Data & B.9 & No Data \\
\hline \multirow[t]{3}{*}{ GJ94-06 } & $01 / 05 / 1995$ & 19.7 & $<.02$ & No Detect & 6.37 & $<1.054$ & $<.005$ & $<.005$ & Table A-7 & No Data & 1210 \\
\hline & $07 / 12 / 1995$ & No Data & $<.02$ & No Data & No Data & No Data & $<.005$ & $<.005$ & No Data & 9.8 & No Data \\
\hline & $10 / 18 / 1995$ & No Data & $<.02$ & No Data & No Data & No Data & $<.005$ & $<.005$ & No Data & 10 & No Data \\
\hline \multirow[t]{4}{*}{ GJ94-07 } & $01 / 10 / 1995$ & 17.8 & $<.02$ & No Detect & $<.5$ & 1.973 & $<.005$ & .025 & Table A-7 & No Data & 1150 \\
\hline & $04 / 11 / 1995$ & No Data & $<.02$ & No Data & No Data & No Data & $<.005$ & .015 & No Data & No Data & No Data \\
\hline & $07 / 13 / 1995$ & No Data & $<.02$ & No Data & No Data & No Data & $<.005$ & $<.005$ & No Data & 6.6 & No Data \\
\hline & $10 / 18 / 1995$ & No Data & $<.02$ & No Data & No Data & No Data & $<.005$ & .012 & No Data & 6.6 & No Data \\
\hline \multirow[t]{4}{*}{ GJ94-08 } & $01 / 10 / 1995$ & 111 & $<.02$ & No Detect & $<.5$ & 1.486 & $<.005$ & .071 & Table A-7 & No Data & 1830 \\
\hline & $04 / 11 / 1995$ & No Data & $<.02$ & No Data & No Data & No Data & $<.005$ & .089 & No Data & No Data & No Data \\
\hline & $07 / 13 / 1995$ & No Data & $<.02$ & No Data & No Data & No Data & $<.005$ & .022 & No Data & 8.5 & No Data \\
\hline & $10 / 18 / 1995$ & No Data & $<.02$ & No Data & No Data & No Data & $<.005$ & .074 & No Data & 10 & No Data \\
\hline \multirow{3}{*}{ GJ94-09 } & $01 / 10 / 1995$ & & $<.02$ & No Detect & $<.5$ & 1.108 & $<.005$ & .071 & Table A-7 & No Data & 1450 \\
\hline & $04 / 12 / 1995$ & No Data & $<.02$ & No Data & No Data & No Data & $<.005$ & .07 & No Data & No Data & No Data \\
\hline & $10 / 19 / 1995$ & No Data & $<.02$ & No Data & No Data & No Data & $<.005$ & .058 & No Data & 7 & No Data \\
\hline \multirow[t]{2}{*}{$p-6$} & $01 / 10 / 1995$ & 5.55 & $<.02$ & No Detect & $<.5$ & .838 & $<.005$ & .006 & Table A-7 & No Data & 643 \\
\hline & $10 / 20 / 1995$ & No Data & $<.02$ & No Data & No Data & No Data & $<.005$ & .04 & No Data & 7.7 & No Data \\
\hline
\end{tabular}

$a_{A}$ "<" symbol indicates that the maximum concentration was below the detection limit (number shown is detection limit).

Badium-226 activities were measured in bequerels per liter and the results were converted to picocuries per liter for reporting purposes. The values 1 isted multiplied by $10^{-9}$ will result in units of microcuries per milliliter.

Refer to Table A-7 for a list of detected constituents. 
Table A-5 (continued). Groundwater Chemistry Data Collected by Oak Ridge National Laboratory At and Near the GJPO During 1995a

\begin{tabular}{|c|c|c|c|c|c|c|}
\hline $\begin{array}{l}\text { Sample } \\
\text { Location }\end{array}$ & $\begin{array}{l}\text { Sample } \\
\text { Date }\end{array}$ & $\underset{(m g / L)}{T 1}$ & $\underset{(m g / L)}{U}$ & $\underset{(\mathrm{mg} / \mathrm{L})}{V}$ & $\begin{array}{c}\text { Volatileb } \\
(\mu g / L)\end{array}$ & $\underset{(m g / L)}{Z n}$ \\
\hline \multirow[t]{3}{*}{$11-1 S$} & $01 / 09 / 1995$ & $<.005$ & .0003 & .0078 & Table A-7 & $<.005$ \\
\hline & $07 / 13 / 1995$ & $<.005$ & .15 & .0066 & No Data & .011 \\
\hline & $10 / 20 / 1995$ & $<.005$ & .71 & .0056 & No Data & $<.005$ \\
\hline \multirow[t]{3}{*}{$14-6 N A$} & $01 / 05 / 1995$ & $<.005$ & .041 & .0032 & Table A-7 & $<.005$ \\
\hline & $07 / 11 / 1995$ & $<.005$ & .15 & .0053 & No Data & .0058 \\
\hline & $10 / 19 / 1995$ & $<.005$ & .074 & .0074 & No Data & $<.005$ \\
\hline $8-4 S$ & $10 / 20 / 1995$ & $<.005$ & .63 & .0024 & No Data & $<.005$ \\
\hline GJ84-04 & $01 / 09 / 1995$ & $<.005$ & .89 & .024 & Table A-7 & $<.005$ \\
\hline \multirow[t]{3}{*}{ G.J84-04-Duplicate } & $01 / 09 / 1995$ & $<.005$ & .88 & .023 & Table A-7 & $<.005$ \\
\hline & $07 / 11 / 1995$ & $<.005$ & .19 & .019 & No Data & .013 \\
\hline & $10 / 19 / 1995$ & $<.005$ & .53 & .022 & No Data & $<.005$ \\
\hline G.J84-05 & $01 / 09 / 1995$ & $<.005$ & .78 & .012 & Table A-7 & $<.005$ \\
\hline \multirow[t]{4}{*}{ GJ94-01 } & $01 / 03 / 1995$ & $<.005$ & .075 & $<.002$ & Table A-7 & $<.005$ \\
\hline & $01 / 10 / 1995$ & No Data & No Data & No Data & No Data & No Data \\
\hline & $07 / 10 / 1995$ & $<.005$ & .032 & .0022 & No Data & .005 \\
\hline & $10 / 17 / 1995$ & $<.005$ & .17 & $<.002$ & No Data & $<.005$ \\
\hline \multirow[t]{3}{*}{ GJ94-02 } & $01 / 03 / 1995$ & $<.005$ & 1 & .0033 & Table A-7 & $<.005$ \\
\hline & $04 / 12 / 1995$ & $<.005$ & 1.1 & $<.002$ & No Data & .032 \\
\hline & $\begin{array}{l}07 / 10 / 1995 \\
10 / 17 / 1995\end{array}$ & $\begin{array}{l}<.005 \\
<.005\end{array}$ & $\begin{array}{l}.53 \\
.61\end{array}$ & $\begin{array}{l}.0027 \\
.0063\end{array}$ & $\begin{array}{l}\text { No Data } \\
\text { No Data }\end{array}$ & $\begin{array}{l}.0076 \\
.0082\end{array}$ \\
\hline \multirow[t]{4}{*}{ GJ94-03 } & $01 / 04 / 1995$ & $<.005$ & .13 & .0036 & Table A-7 & $<.005$ \\
\hline & $04 / 12 / 1995$ & $<.005$ & .16 & $<.002$ & No Data & .045 \\
\hline & $07 / 11 / 1995$ & $<.005$ & .26 & .0027 & No Data & .0058 \\
\hline & $10 / 17 / 1995$ & $<.005$ & .24 & $<.002$ & No Data & .018 \\
\hline \multirow[t]{3}{*}{ GJ94-04 } & $01 / 04 / 1995$ & $<.005$ & .15 & $<.002$ & Table A-7 & $<.005$ \\
\hline & $04 / 10 / 1995$ & $<.005$ & .1 & .0024 & No Data & .0094 \\
\hline & $07 / 12 / 1995$ & $<.005$ & .063 & .0032 & No Data & $<.005$ \\
\hline
\end{tabular}

$a_{A} "<"$ symbol indicates that the maximum concentration was below the detection limit (number shown is detection limit).

Refer to Table A-7 for a 1 ist of detected constituents. 
Table A-5 (continued). Groundwater Chemistry Data Collected by Oak Ridge National Laboratory At and Near the GJPO During 1995a

\begin{tabular}{|c|c|c|c|c|c|c|}
\hline $\begin{array}{l}\text { Sample } \\
\text { Location }\end{array}$ & $\begin{array}{l}\text { Sample } \\
\text { Date }\end{array}$ & $\stackrel{T 1}{(m g / L)}$ & $\underset{(m g / L)}{U}$ & $\underset{(m g / L)}{v}$ & $\begin{array}{l}\text { Volatile } \\
(\mu \mathrm{g} / \mathrm{L})\end{array}$ & $\underset{(m g / L)}{Z n}$ \\
\hline GJ94-04 & $10 / 18 / 1995$ & $<.005$ & .2 & $<.002$ & No Data & .006 \\
\hline \multirow[t]{7}{*}{ GJ94-05 } & $01 / 04 / 1995$ & $<.005$ & .083 & .0095 & Table A-7 & $<.005$ \\
\hline & $04 / 11 / 1995$ & $<.005$ & .081 & .0069 & No Data & .0052 \\
\hline & $04 / 11 / 1995$ & $<.005$ & .081 & .0077 & No Data & .025 \\
\hline & $07 / 12 / 1995$ & $<.005$ & .021 & .0078 & No Data & .0086 \\
\hline & $07 / 12 / 1995$ & $<.005$ & .02 & .0098 & No Data & .0064 \\
\hline & $10 / 18 / 1995$ & $<.005$ & .16 & .008 & No Data & .011 \\
\hline & $10 / 18 / 1995$ & $<.005$ & .15 & .0099 & No Data & .0057 \\
\hline \multirow[t]{3}{*}{ GJ94-06 } & $01 / 05 / 1995$ & $<.005$ & .026 & .0036 & Table A-7 & $<.005$ \\
\hline & $07 / 12 / 1995$ & $<.005$ & $<.0001$ & .0033 & No Data & .013 \\
\hline & $10 / 18 / 1995$ & $<.005$ & .021 & $<.002$ & No Data & $<.005$ \\
\hline \multirow[t]{4}{*}{ GJ94-07 } & $01 / 10 / 1995$ & $<.005$ & .92 & .0034 & Table A-7 & $<.005$ \\
\hline & $04 / 11 / 1995$ & $<.005$ & .98 & .0036 & No Data & .056 \\
\hline & $07 / 13 / 1995$ & $<.005$ & .48 & .0098 & No Data & .0062 \\
\hline & $10 / 18 / 1995$ & $<.005$ & .74 & .0034 & No Data & .0071 \\
\hline \multirow[t]{4}{*}{ GJ94-08 } & $01 / 10 / 1995$ & $<.05$ & .52 & $<.002$ & Table A-7 & $<.005$ \\
\hline & $04 / 11 / 1995$ & $<.005$ & .74 & $<.002$ & No Data & .013 \\
\hline & $07 / 13 / 1995$ & $<.005$ & .46 & .0029 & No Data & .0086 \\
\hline & $10 / 18 / 1995$ & $<.005$ & .86 & $<.002$ & No Data & .0057 \\
\hline \multirow[t]{3}{*}{ GJ94-09 } & $01 / 10 / 1995$ & $<.005$ & .77 & .0023 & Table A-7 & $<.005$ \\
\hline & $04 / 12 / 1995$ & $<.005$ & .74 & $<.002$ & No Data & .014 \\
\hline & $10 / 19 / 1995$ & $<.005$ & .81 & $<.002$ & No Data & .0056 \\
\hline \multirow[t]{2}{*}{$P-6$} & $01 / 10 / 1995$ & $<.005$ & .017 & .0023 & Table A-7 & $<.005$ \\
\hline & $10 / 20 / 1995$ & $<.005$ & .038 & .003 & No Data & .0064 \\
\hline
\end{tabular}

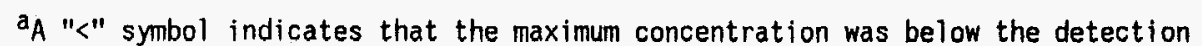
$1 \mathrm{imit}$ (number shown is detection limit).

Refer to Table A-7 for a 1ist of detected constituents. 
Table A-6. QA/QC Data Collected by Oak Ridge National Laboratory At and Near the GJPO During 1995a

\begin{tabular}{|c|c|c|c|c|c|c|c|c|c|c|c|}
\hline $\begin{array}{c}\text { Sample } \\
\text { Location }\end{array}$ & $\begin{array}{c}\text { Sample } \\
\text { Date }\end{array}$ & $\underset{(m g / L)}{A g}$ & $\begin{array}{c}\mathrm{Al} \\
(\mathrm{mg} / \mathrm{L})\end{array}$ & $\underset{(\mathrm{mg} / \mathrm{L})}{\text { As }}$ & $\underset{(\mathrm{mg} / L)}{B}$ & $\underset{(\mathrm{mg} / \mathrm{L})}{\mathrm{Ba}}$ & $\begin{array}{c}\mathrm{Be} \\
(\mathrm{mg} / \mathrm{L})\end{array}$ & $\underset{(\mathrm{mg} / \mathrm{L})}{\mathrm{Ca}}$ & $\underset{(m g / L)}{C d}$ & $\begin{array}{c}C 1 \\
(\mathrm{mg} / \mathrm{L})\end{array}$ & $\underset{(\mathrm{mg} / \mathrm{L})}{\mathrm{Co}}$ \\
\hline $\begin{array}{l}\text { Sample } \\
\text { Location }\end{array}$ & $\begin{array}{c}\text { Sample } \\
\text { Date }\end{array}$ & $\underset{(m g / L)}{C r}$ & $\begin{array}{c}\mathrm{Cu} \\
(\mathrm{mg} / \mathrm{L})\end{array}$ & $\underset{(m g / L)}{F e}$ & $\underset{(\mathrm{mg} / \mathrm{L})}{\mathrm{Hg}}$ & $\underset{(m g / L)}{K}$ & $\underset{(\mathrm{mg} / \mathrm{L})}{\mathrm{Mg}}$ & $\underset{(m g / L)}{M n}$ & $\begin{array}{c}\text { Mo } \\
(\mathrm{mg} / \mathrm{L})\end{array}$ & $\begin{array}{c}\mathrm{Na} \\
(\mathrm{mg} / \mathrm{L})\end{array}$ & $\begin{array}{c}M i \\
(\mathrm{mg} / \mathrm{L})\end{array}$ \\
\hline Field Blank & $\begin{array}{l}01 / 05 / 1995 \\
04 / 12 / 1995 \\
07 / 13 / 1995\end{array}$ & $\begin{array}{l}<.004 \\
<.004 \\
<.004\end{array}$ & $\begin{array}{l}.014 \\
.013 \\
.023\end{array}$ & $\begin{array}{l}.14 \\
.082 \\
.072\end{array}$ & $\begin{array}{r}.00011 \\
<.00005 \\
<.00005\end{array}$ & $\begin{array}{l}<2 \\
<2 \\
<2\end{array}$ & $\begin{array}{l}9.5 \\
12 \\
9.3\end{array}$ & $\begin{array}{l}.0055 \\
.0043 \\
.0095\end{array}$ & $\begin{array}{l}<.04 \\
<.04 \\
<.04\end{array}$ & $\begin{array}{l}11 \\
15 \\
12\end{array}$ & $\begin{array}{l}<.01 \\
<.01 \\
<.01\end{array}$ \\
\hline $\begin{array}{l}\text { GJ94-01 Equip. Rinse } \\
\text { GJ94-07 Equip. Rinse } \\
\text { GJ94-09 Equip. Rinse } \\
\text { Trip Blank }\end{array}$ & $\begin{array}{l}01 / 03 / 1995 \\
04 / 11 / 1995 \\
07 / 13 / 1995 \\
10 / 19 / 1995 \\
01 / 09 / 1995 \\
01 / 10 / 1995 \\
10 / 20 / 1995 \\
10 / 20 / 1995\end{array}$ & $\begin{array}{l}<.004 \\
<.004 \\
<.004 \\
<.004 \\
\text { No Data } \\
\text { No Data } \\
<.004 \\
<.004\end{array}$ & $\begin{array}{c}<.007 \\
.0096 \\
.026 \\
.032 \\
\text { No Data } \\
\text { No Data } \\
<.007 \\
<.007\end{array}$ & $\begin{array}{c}<.05 \\
<.05 \\
<.05 \\
.18 \\
\text { No Data } \\
\text { No Data } \\
.24 \\
<.05\end{array}$ & $\begin{array}{r}.00012 \\
<.00005 \\
<.00005 \\
<.00005 \\
\text { No Data } \\
\text { No Data } \\
<.00005 \\
.00005\end{array}$ & $\begin{array}{l}\text { No Data } \\
<2 \\
<2 \\
<2 \\
\text { No Data } \\
\text { No Data } \\
<2 \\
<2\end{array}$ & $\begin{array}{l}12.072 \\
9.2 \\
9.3 \\
\text { No Data } \\
\text { No Data } \\
<.02 \\
<.02\end{array}$ & $\begin{array}{c}.0082 \\
.0039 \\
.0048 \\
.016 \\
\text { No Data } \\
\text { No Data } \\
.0014 \\
<.001\end{array}$ & $\begin{array}{l}<.04 \\
<.04 \\
<.04 \\
<.04 \\
\text { No Data } \\
\text { No Data } \\
<.04 \\
<.04\end{array}$ & $\begin{array}{l}15^{.26} \\
12 \\
10 \\
\text { No Data } \\
\text { No Data } \\
.083 \\
.1\end{array}$ & $\begin{array}{c}<.01 \\
<.01 \\
<.01 \\
.014 \\
\text { No Data } \\
\text { No Data } \\
<.01 \\
.011\end{array}$ \\
\hline
\end{tabular}

$a_{A} "<"$ symbol indicates that the maximum concentration was below the detection 1 imit (number shown is detection 1 imit). 
Table A-6 (continued). QA/QC Data Collected by Oak Ridge National Laboratory At and Near the GJPO during $1995^{\mathrm{a}}$

\begin{tabular}{|c|c|c|c|c|c|c|c|c|c|c|c|}
\hline $\begin{array}{l}\text { Sample } \\
\text { Location }\end{array}$ & $\begin{array}{l}\text { Sample } \\
\text { Date }\end{array}$ & $\stackrel{\mathrm{NO}_{3}}{(\mathrm{mg} / \mathrm{L})}$ & $\begin{array}{c}\mathrm{Pb} \\
(\mathrm{mg} / \mathrm{L})\end{array}$ & $\begin{array}{l}\text { Pesticide } \\
(\mu \mathrm{g} / \mathrm{L})\end{array}$ & $\underset{(\mathrm{mg} / \mathrm{L})}{\mathrm{PO}_{4}}$ & $\begin{array}{l}\mathrm{Ra}-226^{\mathrm{b}} \\
(\mathrm{pCi} / \mathrm{L})\end{array}$ & $\underset{(m g / L)}{S b}$ & $\begin{array}{c}\text { Se } \\
(\mathrm{mg} / \mathrm{L})\end{array}$ & $\underset{(\mu g / L)}{\text { Semivolatile }}$ & $\underset{(m g / L)}{S i}$ & $\underset{(\mathrm{mg} / \mathrm{L})}{\mathrm{SO}_{4}}$ \\
\hline $\begin{array}{l}\text { Field Blank } \\
\text { GJ94-01 Equip. Rinse } \\
\text { GJ94-07 Equip. Rinse } \\
\text { GJ94-09 Equip. Rinse } \\
\text { Trip Blank }\end{array}$ & $\begin{array}{l}01 / 05 / 1995 \\
04 / 12 / 1995 \\
07 / 13 / 1995 \\
01 / 03 / 1995 \\
04 / 11 / 1995 \\
07 / 13 / 1995 \\
10 / 19 / 1995 \\
01 / 09 / 1995 \\
01 / 10 / 1995 \\
10 / 20 / 1995 \\
10 / 20 / 1995\end{array}$ & $\begin{array}{l}2.33 \\
\text { No Data } \\
\text { No Data } \\
\text { <.1 } \\
\text { No Data } \\
\text { No Data } \\
\text { No Data } \\
\text { No Data } \\
\text { No Oata } \\
\text { No Data } \\
\text { No Data }\end{array}$ & $\begin{array}{l}<.02 \\
<.02 \\
<.02 \\
<.02 \\
<.02 \\
<.02 \\
<.02 \\
\text { No Data } \\
\text { No Data } \\
<.02 \\
<.02\end{array}$ & $\begin{array}{l}\text { No Detect } \\
\text { No Data } \\
\text { No Data } \\
\text { No Detect } \\
\text { No Data } \\
\text { No Data } \\
\text { No Data } \\
\text { No Data } \\
\text { No Data } \\
\text { No Data } \\
\text { No Data }\end{array}$ & $\begin{array}{l}3.39 \\
\text { No Data } \\
\text { No Data } \\
\text { <.5 } \\
\text { No Data } \\
\text { No Data } \\
\text { No Data } \\
\text { No Data } \\
\text { No Data } \\
\text { No Data } \\
\text { No Data }\end{array}$ & $\begin{array}{l}.13513 \\
\text { No Data } \\
\text { No Data } \\
.02702 \\
\text { No Data } \\
\text { No Data } \\
\text { No Data } \\
\text { No Data } \\
\text { No Data } \\
\text { No Data } \\
\text { No Data }\end{array}$ & $\begin{array}{l}<.005 \\
<.005 \\
<.005 \\
<.005 \\
<.005 \\
<.005 \\
<.005 \\
\text { No Data } \\
\text { No Data } \\
<.005 \\
<.005\end{array}$ & $\begin{array}{l}<.005 \\
<.005 \\
<.005 \\
<.005 \\
<.005 \\
<.005 \\
<.005 \\
\text { No Data } \\
\text { No Data } \\
<.005 \\
<.005\end{array}$ & $\begin{array}{l}\text { Table A-7 } \\
\text { No Data } \\
\text { No Data } \\
\text { Table A-7 } \\
\text { No Data } \\
\text { No Data } \\
\text { No Data } \\
\text { No Detect } \\
\text { No Detect } \\
\text { No Data } \\
\text { No Data }\end{array}$ & $\begin{array}{l}\text { No Data } \\
\text { No Data } \\
6 \\
\text { No Data } \\
\text { No Data } \\
6 \\
5.9 \\
\text { No Data } \\
\text { No Data } \\
<.2 \\
<.2\end{array}$ & $\begin{array}{l}53.1 \\
\text { No Data } \\
\text { No Data } \\
\text {.55 } \\
\text { No Data } \\
\text { No Data } \\
\text { No Data } \\
\text { No Data } \\
\text { No Data } \\
\text { No Data } \\
\text { No Data }\end{array}$ \\
\hline $\begin{array}{l}\text { Sample } \\
\text { Location }\end{array}$ & $\begin{array}{l}\text { Sample } \\
\text { Date }\end{array}$ & $\begin{array}{c}T^{\prime} \\
(\mathrm{mg} / \mathrm{L})\end{array}$ & $\begin{array}{c}u \\
(m g / L)\end{array}$ & $\underset{(m g / L)}{V}$ & $\begin{array}{c}\text { Volatile } \\
(\mu \mathrm{g} / \mathrm{L})\end{array}$ & $\underset{(m g / L)}{Z n}$ & & & & & \\
\hline $\begin{array}{l}\text { Field Blank } \\
\text { GJ94-01 Equip. Rinse } \\
\text { GJ94-07 Equip. Rinse } \\
\text { GJ94-09 Equip. Rinse } \\
\text { Trip Blank }\end{array}$ & $\begin{array}{l}01 / 05 / 1995 \\
04 / 12 / 1995 \\
07 / 13 / 1995 \\
01 / 03 / 1995 \\
04 / 11 / 1995 \\
07 / 13 / 1995 \\
10 / 19 / 1995 \\
01 / 09 / 1995 \\
01 / 10 / 1995 \\
10 / 20 / 1995 \\
10 / 20 / 1995\end{array}$ & $\begin{array}{l}<.005 \\
<.005 \\
<.005 \\
<.005 \\
<.005 \\
<.005 \\
<.005 \\
\text { No Data } \\
\text { No Data } \\
<.005 \\
<.005\end{array}$ & $\begin{array}{c}.0008 \\
.00086 \\
.56 \\
<.0001 \\
.0011 \\
.00052 \\
.00088 \\
\text { No Data } \\
\text { No Data } \\
<.0001 \\
<.0001\end{array}$ & $\begin{array}{c}<.002 \\
.0022 \\
<.002 \\
<.002 \\
<.002 \\
<.002 \\
<.002 \\
\text { No Data } \\
\text { No Data } \\
<.002 \\
<.002\end{array}$ & $\begin{array}{l}\text { Table A-7 } \\
\text { No Data } \\
\text { No Data } \\
\text { Table A-7 } \\
\text { No Data } \\
\text { No Data } \\
\text { No Data } \\
\text { Table A-7 } \\
\text { Table A-7 } \\
\text { No Data } \\
\text { No Data }\end{array}$ & $\begin{array}{l}.35 \\
.48 \\
.34 \\
.0064 \\
.31 \\
.25 \\
.27 \\
\text { No Data } \\
\text { No Data } \\
<.005 \\
<.005\end{array}$ & & & & $\cdot$ & \\
\hline
\end{tabular}

$a_{A}$ " $<"$ symbol indicates that the maximum concentration was below the detection limit (number shown is detection 1 imit).

badium-226 activities were measured in bequerels per liter and the results were converted to picocuries per 1 iter for reporting purposes. The values 1 isted multiplied by $10^{-9}$ will result in $\mu \mathrm{Ci} / \mathrm{mL}$.

CRefer to Table A-7 for a list of detected constituents. 
Table A-7. Organic Constituents Detected in Samples Collected by Oak Ridge National Laboratory From Groundwater At and Near the GJPO during 1995a

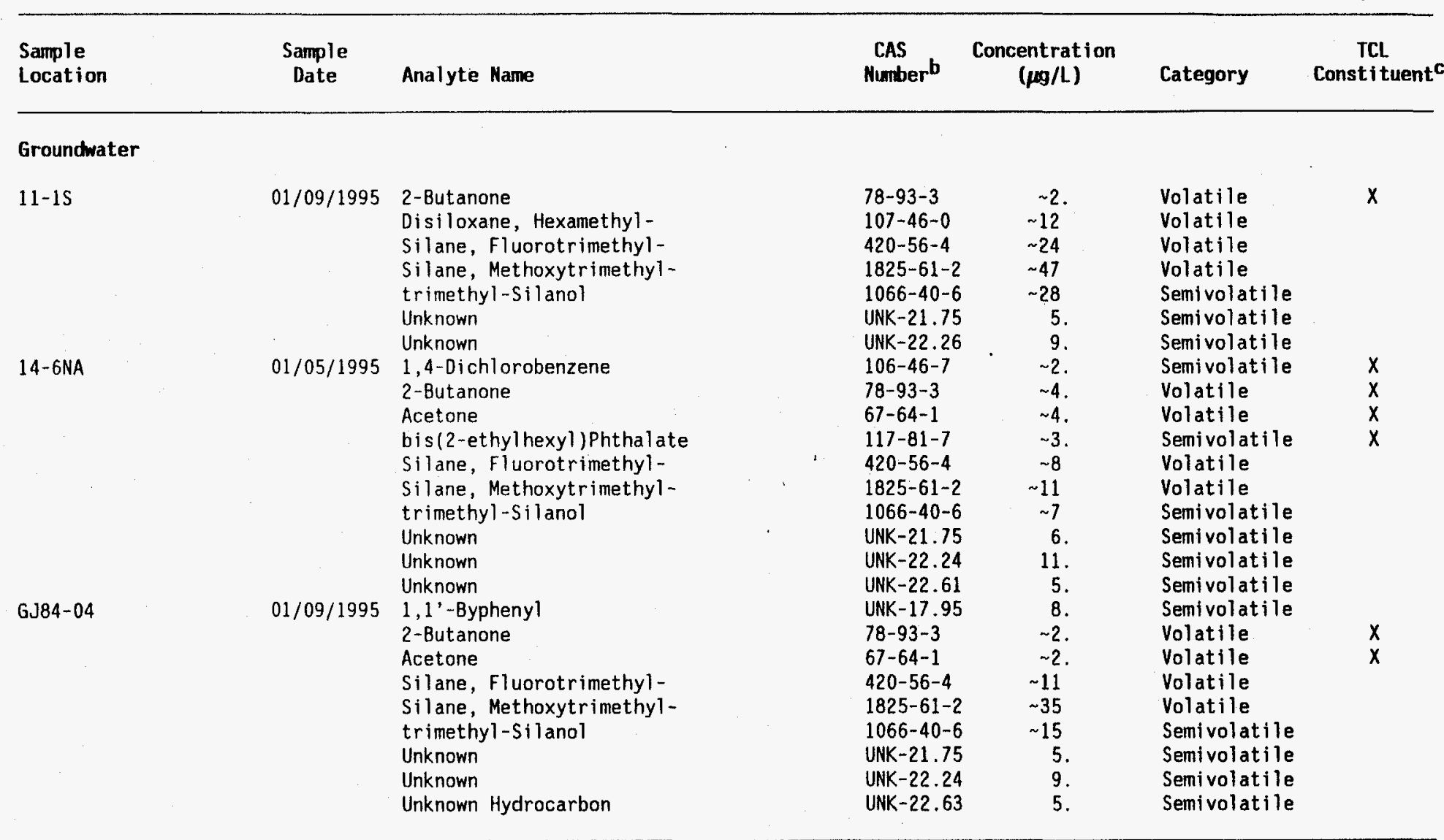

$a_{A}$ " " indicates an approximate value (the value was outside the limits for which the instrument was calibrated).

Chemical Abstracts Service (CAS) numbers are not assigned to unknown analytes; identifiers listed in this column for unknown analytes reflect the peak and range as displayed graphically by the mass spectrometer.

cConstituents identified by an " $X$ " are Target Compound List constituents; organic constituents not identified by an " $X$ " are tentatively identified compounds. 
Table A-7 (continued). Organic Constituents Detected in Samples Collected by Oak Ridge National Laboratory From Groundwater At and Near the GJPO During 1995a

\begin{tabular}{|c|c|c|c|c|c|c|}
\hline $\begin{array}{l}\text { Sample } \\
\text { Location }\end{array}$ & $\begin{array}{l}\text { Sample } \\
\text { Date }\end{array}$ & Analyte Name & $\begin{array}{c}\text { CAS } \\
\text { Numberb }\end{array}$ & $\begin{array}{c}\text { Concentration } \\
(\mu \mathrm{g} / \mathrm{L})\end{array}$ & Category & $\begin{array}{c}\mathrm{TCL} \\
\text { Constituent }^{\mathrm{C}}\end{array}$ \\
\hline \multicolumn{7}{|c|}{ Groundwater } \\
\hline GJ84-04 & $01 / 09 / 1995$ & $\begin{array}{l}\text { 2-Butanone } \\
\text { Acetone } \\
\text { Unknown } \\
\text { Unknown } \\
\text { Unknown }\end{array}$ & $\begin{array}{l}78-93-3 \\
67-64-1 \\
\text { UNK }-21.73 \\
\text { UNK }-22.24 \\
\text { UNK-22.61 }\end{array}$ & $\begin{array}{c}\sim 3 \\
\sim 4 \\
9 \\
17 \\
7\end{array}$ & $\begin{array}{l}\text { Volatile } \\
\text { Volatile } \\
\text { Semivolatile } \\
\text { Semivolatile } \\
\text { Semivolatile }\end{array}$ & $\begin{array}{l}x \\
x\end{array}$ \\
\hline G.J84-05 & $01 / 09 / 1995$ & $\begin{array}{l}\text { 2-Butanone } \\
\text { Acetone } \\
\text { Benzene Derivative } \\
\text { Silane, Fluorotrimethyl- } \\
\text { Silane, Methoxytrimethyl- } \\
\text { trimethyl-Silanol } \\
\text { Unknown } \\
\text { Unknown } \\
\text { Unknown } \\
\text { Unknown } \\
\text { Unknown }\end{array}$ & $\begin{array}{l}78-93-3 \\
67-64-1 \\
\text { UNK-21.17 } \\
420-56-4 \\
1825-61-2 \\
1066-40-6 \\
\text { UNK-21.37 } \\
\text { UNK-21.76 } \\
\text { UNK-22.25a } \\
\text { UNK-22.61 } \\
\text { UNK-6.66 }\end{array}$ & $\begin{array}{r}\sim 2 \\
\sim 3 \\
5 \\
-27 \\
\sim 31 \\
\sim 14 \\
5 \\
12 . \\
22 \\
11 \\
10\end{array}$ & $\begin{array}{l}\text { Volatile } \\
\text { Volatile } \\
\text { Semivolatile } \\
\text { Volatile } \\
\text { Volatile } \\
\text { Semivolatile } \\
\text { Semivolatile } \\
\text { Semivolatile } \\
\text { Semivolatile } \\
\text { Semivolatile } \\
\text { Semivolatile }\end{array}$ & $\begin{array}{l}x \\
x\end{array}$ \\
\hline GJ94-01 & $01 / 03 / 1995$ & $\begin{array}{l}\text { 2-Butanone } \\
\text { Acetone } \\
\text { Unknown } \\
\text { Unknown } \\
\text { Unknown } \\
\text { Unknown } \\
\text { Unknown }\end{array}$ & $\begin{array}{l}78-93-3 \\
67-64-1 \\
\text { UNK-22.23 } \\
\text { UNK-6.62 } \\
\text { UNK-7.23 } \\
\text { UNK-7.47 } \\
\text { UNK-7.69 }\end{array}$ & $\begin{array}{r}\sim 2 . \\
\sim 3 . \\
6 . \\
11 . \\
5 . \\
14 . \\
23 .\end{array}$ & $\begin{array}{l}\text { Volatile } \\
\text { Volatile } \\
\text { Semivolatile } \\
\text { Semivolatile } \\
\text { Semivolatile } \\
\text { Semivolatile } \\
\text { Semivolatile }\end{array}$ & $\begin{array}{l}x \\
x\end{array}$ \\
\hline
\end{tabular}

$a_{A} " \sim "$ indicates an approximate value (the value was outside the limits for which the instrument was calibrated).

${ }^{b}$ Chemical Abstracts Service (CAS) numbers are not assigned to unknown analytes; identifiers 1 isted in this column for unknown analytes reflect the peak and range as displayed graphically by the mass spectrometer.

cConstituents identified by an " $X$ " are Target Compound List constituents; organic constituents not identified by an " $X$ " are tentatively identified compounds. 
Table A-7 (continued). Organic Constituents Detected in Samples Collected by Oak Ridge National Laboratory From Groundwater At and Near the GJPO During 1995a

\begin{tabular}{|c|c|c|c|c|c|c|}
\hline $\begin{array}{l}\text { Sample } \\
\text { Location }\end{array}$ & $\begin{array}{l}\text { Sample } \\
\text { Date }\end{array}$ & Analyte Name & $\begin{array}{l}\text { CAS } \\
\text { Number }\end{array}$ & $\begin{array}{c}\text { Concentration } \\
(\mu \mathrm{g} / \mathrm{L})\end{array}$ & Category & $\begin{array}{c}\text { ICL } \\
\text { Constituent }^{\mathrm{C}}\end{array}$ \\
\hline \multicolumn{7}{|c|}{ Groundwater } \\
\hline GJ94-02 & 01/03/1995 & $\begin{array}{l}\text { 2-Butanone } \\
\text { Acetone } \\
\text { Unknown } \\
\text { Unknown } \\
\text { Unknown } \\
\text { Unknown } \\
\text { Unknown } \\
\text { Unknown }\end{array}$ & $\begin{array}{l}78-93-3 \\
67-64-1 \\
\text { UNK-22.22 } \\
\text { UNK-6.60a } \\
\text { UNK-7.23 } \\
\text { UNK-7.37 } \\
\text { UNK-7.47 } \\
\text { UNK-7.70 }\end{array}$ & $\begin{array}{r}\sim 2 . \\
\sim 2 . \\
7 . \\
12 . \\
6 . \\
8 . \\
23 . \\
27 .\end{array}$ & $\begin{array}{l}\text { Volatile } \\
\text { Volatile } \\
\text { Semivolatile } \\
\text { Semivolatile } \\
\text { Semivolatile } \\
\text { Semivolatile } \\
\text { Semivolatile } \\
\text { Semivolatile }\end{array}$ & $\begin{array}{l}x \\
x\end{array}$ \\
\hline GJ94-03 & $01 / 04 / 1995$ & $\begin{array}{l}\text { 2-Butanone } \\
\text { Acetone } \\
\text { Unknown } \\
\text { Unknown } \\
\text { Unknown } \\
\text { Unknown } \\
\text { Unknown } \\
\text { Unknown } \\
\text { Unknown }\end{array}$ & $\begin{array}{l}78-93-3 \\
67-64-1 \\
\text { UNK-22.22 } \\
\text { UNK-4.29 } \\
\text { UNK }-6.62 \\
\text { UNK-7.23 } \\
\text { UNK-7.37 } \\
\text { UNK-7.47 } \\
\text { UNK-7.69 }\end{array}$ & $\begin{array}{r}\sim 3 \\
\sim 4 \\
7 . \\
\sim 7 \\
15 \\
7 . \\
9 . \\
27 \\
34\end{array}$ & $\begin{array}{l}\text { Volatile } \\
\text { Volatile } \\
\text { Semivolatile } \\
\text { Volatile } \\
\text { Semivolatile } \\
\text { Semivolatile } \\
\text { Semivolatile } \\
\text { Semivolatile } \\
\text { Semivolatile }\end{array}$ & $\begin{array}{l}x \\
x\end{array}$ \\
\hline GJ94-04 & $01 / 04 / 1995$ & $\begin{array}{l}\text { 2-Butanone } \\
\text { Acetone } \\
\text { Unknown }\end{array}$ & $\begin{array}{l}78-93-3 \\
67-64-1 \\
\text { UNK-22.22 }\end{array}$ & $\begin{array}{l}\sim 2 \\
\sim 3 \\
\sim 7\end{array}$ & $\begin{array}{l}\text { Volatile } \\
\text { Volatile } \\
\text { Semivolatile }\end{array}$ & $\begin{array}{l}x \\
x\end{array}$ \\
\hline GJ94-05 & $01 / 04 / 1995$ & $\begin{array}{l}\text { 1,4-Dichlorobenzene } \\
\text { 2-Butanone } \\
\text { Acetone } \\
\text { Silane, Fluorotrimethyl- } \\
\text { Silane, Methoxytrimethyl- } \\
\text { trimethyl-Silanol } \\
\text { Unknown } \\
\text { Unknown }\end{array}$ & $\begin{array}{l}106-46-7 \\
78-93-3 \\
67-64-1 \\
420-56-4 \\
1825-61-2 \\
1066-40-6 \\
\text { UNK-22.22 } \\
\text { UNK-6.52 }\end{array}$ & $\begin{array}{l}\sim 1 \\
\sim 2 \\
\sim 3 \\
\sim 10 \\
\sim 13 \\
\sim 8 \\
6 \\
6 \\
6\end{array}$ & $\begin{array}{l}\text { Semivolatile } \\
\text { Volatile } \\
\text { Volatile } \\
\text { Volatile } \\
\text { Volatile } \\
\text { Semivolatile } \\
\text { Semivolatile } \\
\text { Semivolatile }\end{array}$ & $\begin{array}{l}x \\
x \\
x\end{array}$ \\
\hline
\end{tabular}

$a_{A}$ " " indicates an approximate value (the value was outside the limits for which the instrument was calibrated).

${ }^{b}$ Chemical Abstracts Service (CAS) numbers are not assigned to unknown analytes; identifiers listed in this column for unknown analytes reflect the peak and range as displayed graphically by the mass spectrometer.

"Constituents identified by an " $X$ " are Target Compound List constituents; organic constituents not identified by an " $X$ " are tentatively identified compounds. 
Table A-7 (continued). Organic Constituents Detected in Samples Collected by Oak Ridge National Laboratory From Groundwater At and Near the GJPO During 1995a

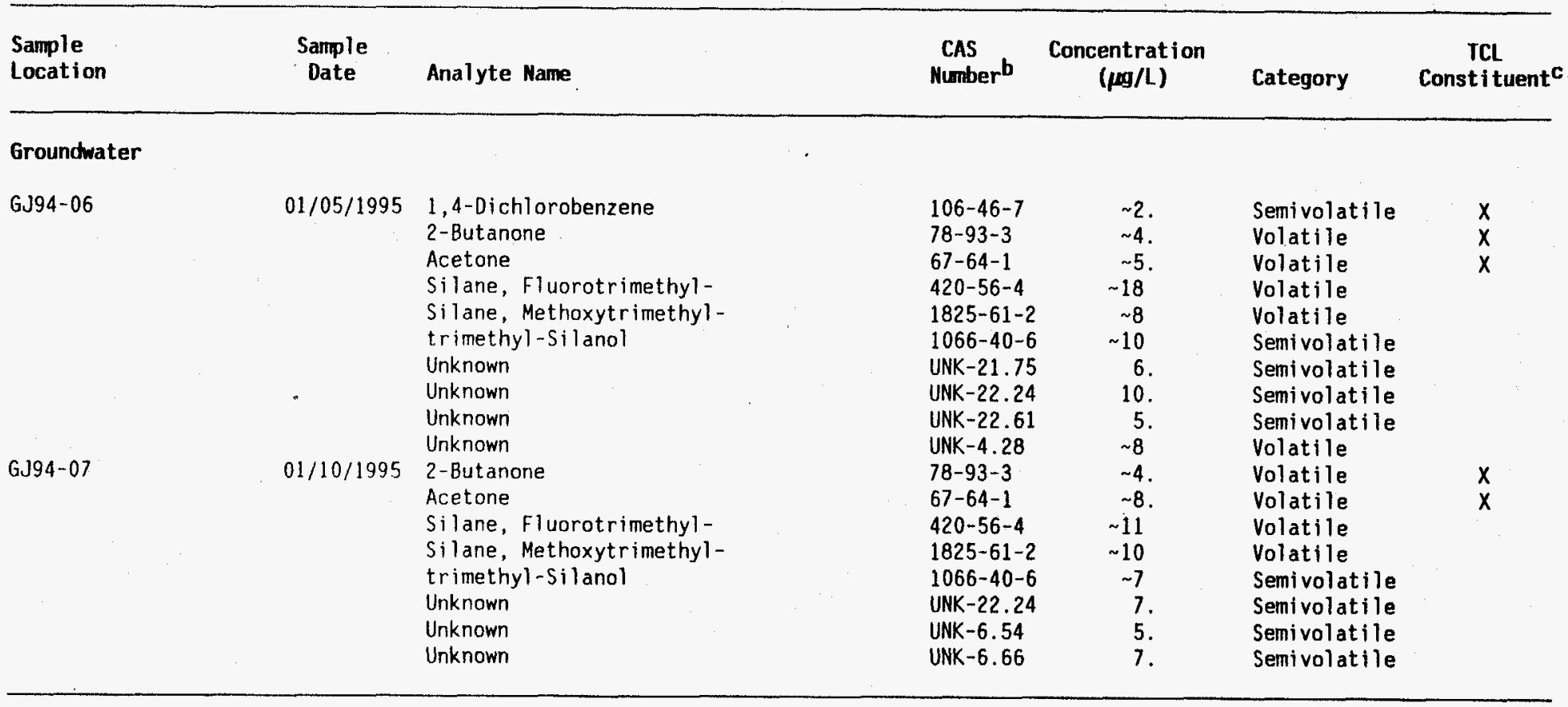

aA " $"$ indicates an approximate value (the value was outside the limits for which the instrument was calibrated).

bhemical Abstracts Service (CAS) numbers are not assigned to unknown analytes; identifiers listed in this column for unknown analytes reflect the peak and range as displayed graphically by the mass spectrometer.

${ }^{c}$ Constituents identified by an " $X$ " are Target Compound List constituents; organic constituents not identified by an " $X$ " are tentatively identified compounds. 
Table A-7 (continued). Organic Constituents Detected in Samples Collected by Oak Ridge National Laboratory From Groundwater At and Near the GJPO During 1995a

\begin{tabular}{|c|c|c|c|c|c|c|}
\hline $\begin{array}{l}\text { Sample } \\
\text { Location }\end{array}$ & $\begin{array}{c}\text { Sample } \\
\text { Date }\end{array}$ & Analyte Nane & $\begin{array}{l}\text { CAS } \\
\text { Number }\end{array}$ & $\begin{array}{c}\text { Concentration } \\
(\mu \mathrm{g} / \mathrm{L})\end{array}$ & Category & $\begin{array}{c}\text { TCL } \\
\text { Consti tuent }\end{array}$ \\
\hline \multicolumn{7}{|c|}{ Groundwater } \\
\hline GJ94-08 & $01 / 10 / 1995$ & $\begin{array}{l}\text { 2-Butanane } \\
\text { Acetone } \\
\text { Silane, Fluorotrimethyl- } \\
\text { Silane, Methoxytrimethyl- } \\
\text { trimethyl-Silanol } \\
\text { Unknown } \\
\text { Unknown } \\
\text { Unknown } \\
\text { Unknown } \\
\text { Unknown } \\
\text { Unknown } \\
\text { Unknown } \\
\text { Unknown }\end{array}$ & $\begin{array}{l}78-93-3 \\
67-64-1 \\
420-56-4 \\
1825-61-2 \\
1066-40-6 \\
\text { UNK-12.59 } \\
\text { UNK-12.88 } \\
\text { UNK-15.50 } \\
\text { UNK-18.06 } \\
\text { UNK-22.24 } \\
\text { UNK-4.30 } \\
\text { UNK-6.53 } \\
\text { UNK-6.64 }\end{array}$ & $\begin{array}{r}\sim 4 \\
\sim 4 \\
\sim 6 \\
\sim 17 \\
\sim 24 \\
13 \\
7 \\
11 \\
12 \\
7 \\
\sim 6 \\
7 \\
10 \\
\end{array}$ & $\begin{array}{l}\text { Volatile } \\
\text { Volatile } \\
\text { Volatile } \\
\text { Volatile } \\
\text { Semivolatile } \\
\text { Semivolatile } \\
\text { Semivolatile } \\
\text { Semivolatile } \\
\text { Semivolatile } \\
\text { Semivolatile } \\
\text { Volatile } \\
\text { Semivolatile } \\
\text { Semivolatile }\end{array}$ & $\begin{array}{l}x \\
x\end{array}$ \\
\hline GJ94-09 & $01 / 10 / 1995$ & $\begin{array}{l}\text { 2-Butanone } \\
\text { 2-Propanol } \\
\text { Acetone } \\
\text { Unknown } \\
\text { Unknown } \\
\text { Unknown } \\
\text { Unknown } \\
\text { Unknown } \\
\text { Unknown }\end{array}$ & $\begin{array}{l}78-93-3 \\
67-63-0 \\
67-64-1 \\
\text { UNK-12.59 } \\
\text { UNK-15.52 } \\
\text { UNK-21.75 } \\
\text { UNK-22.24 } \\
\text { UNK-4.30 } \\
\text { UNK-6.64 }\end{array}$ & $\begin{array}{l}\sim 4.00 \\
\sim 8 \\
\sim 3 \\
4 . \\
5 . \\
6 . \\
11 . \\
\sim 8 \\
5 .\end{array}$ & $\begin{array}{l}\text { Volatile } \\
\text { Volatile } \\
\text { Volatile } \\
\text { Semivolatile } \\
\text { Semivolatile } \\
\text { Semivolatile } \\
\text { Semivolatile } \\
\text { Volatile } \\
\text { Semivolatile }\end{array}$ & $\begin{array}{l}x \\
x\end{array}$ \\
\hline
\end{tabular}

${ }_{A}^{a}$ " " indicates an approximate value (the value was outside the limits for which the instrument was calibrated).

bChemical Abstracts Service (CAS) numbers are not assigned to unknown analytes; identifiers 1 isted in this column for unknown analytes reflect the peak and range as displayed graphically by the mass spectrometer.

cConstituents identified by an " $X$ " are Target Compound List constituents; arganic constituents not identified by an " $X$ " are tentatively identified compounds. 
Table A-7 (continued). Organic Constituents Detected in Samples Collected by Oak Ridge National Laboratory From Groundwater At and Near the GJPO During 1995a

\begin{tabular}{|c|c|c|c|c|c|c|}
\hline $\begin{array}{l}\text { Sample } \\
\text { Location }\end{array}$ & $\begin{array}{l}\text { Sample } \\
\text { Date }\end{array}$ & Analyte Name & $\begin{array}{l}\text { CAS } \\
\text { Mumberb }\end{array}$ & $\begin{array}{c}\text { Concentration } \\
(\mu g / L)\end{array}$ & Category & $\begin{array}{c}\mathrm{TCL} \\
\text { Consti tuent }\end{array}$ \\
\hline
\end{tabular}

Groundwater

P-6

$01 / 10 / 1995$

2-Butanone

2-Propano

Acetone

Diethylphthalate

Unknown

Unknown

Unknown

Unknown

$78-93-3$
$67-63-0$
$67-64-1$
$84-66-2$
UNK-21.73
UNK-22.24
UNK-29.21
UNK-6.52

$\sim 4$
$\sim 26$
$\sim 3$
$\sim 1$
4
8
9
8
8

Volatile

Volatile

Volatile

Semivolatile

Semivolatile

Semivolatile

Semivolatile

UNK-6.52

Semivolatile

QA/QC

Field Blank

01/05/1995 2-Butanone

Acetone

Bromodichloromethane

Silane, Fluorotrimethyl-

$67-64-1$

75-27-4

Silane, Methoxytrimethyl-

Siloxane (Column Bleed)

$420-56-4$

$1825-61-2$

trimethyl-Silanol

UNK -6.72

1066-40-6

Unknown

UNK -21.73

Unknown

UNK-22.22

Unknown

UNK-6.27

Unknown

UNK -6.52

Unknown

UNK -7.69

$\begin{aligned} \sim 4 . & \text { Volatile } \\ \sim 9 . & \text { Volatile } \\ \sim 4 . & \text { Volatile } \\ \sim 33 & \text { Volatile } \\ \sim 35 & \text { Volatile } \\ 5 . & \text { Semivolatile } \\ \sim 33 & \text { Semivolatile } \\ 5 . & \text { Semivolatile } \\ 9 . & \text { Semivolatile } \\ 28 . & \text { Semivolatile } \\ 8 . & \text { Semivolatile } \\ 7 . & \text { Semivolatile }\end{aligned}$

$a_{A}$ " " indicates an approximate value (the value was outside the limits for which the instrument was calibrated).

bChemical Abstracts Service (CAS) numbers are not assigned to unknown analytes; identifiers listed in this column for unknown analytes reflect the peak and range as displayed graphically by the mass spectrometer.

"Constituents identified by an " $X$ " are Target Compound List constituents; organic constituents not identified by an " $X$ " are tentatively ident ified compounds. 
Table A-7 (continued). Organic Constituents Detected in Samples Collected by Oak Ridge National Laboratory From Groundwater At and Near the GJPO During 1995a

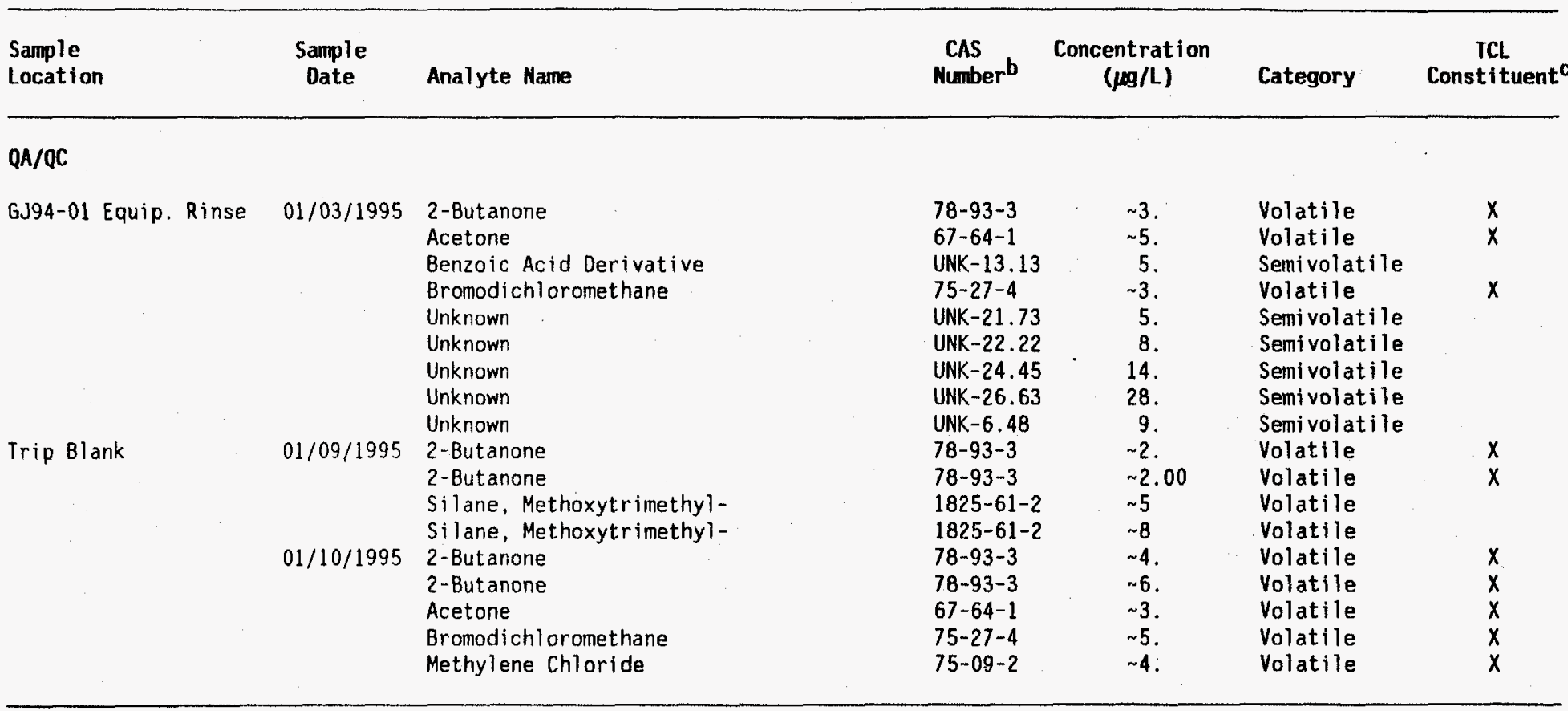

A " " indicates an approximate value (the value was outside the limits for which the instrument was calibrated).

b Chemical Abstracts Service (CAS) numbers are not assigned to unknown analytes; identifiers listed in this column for unknown analytes reflect the peak and range as displayed graphically by the mass spectrometer

cConstituents identified by an " $X$ " are Target Compound List constituents; organic constituents not identified by an " $X$ " are tentatively identified compounds. 
Table A-8. Target Compound List of Organic Constituents Included in Analysis of Groundwater Samples

CAS Number ${ }^{a}$ Constituent Reporting Limit ( $\left.\mu \mathrm{g} / \mathrm{L}\right)$

\section{Pesticides}

$\begin{array}{lll}72-54-8 & 4,4^{\prime} \text { '-DDD } & 0.10 \\ 72-55-9 & 4,4^{\prime},-D D E & 0.10 \\ 50-29-3 & 4,4^{\prime}-\text { DDT } & 0.10 \\ 309-00-2 & \text { Aldrin } & 0.05 \\ 319-84-6 & \text { alpha-BHC } & 0.05 \\ 5103-71-9 & \text { alpha-Chlordane } & 0.50 \\ 12674-11-2 & \text { Aroclor-1016 } & 0.50 \\ 11104-28-2 & \text { Aroclor-1221 } & 0.50 \\ 11141-16-5 & \text { Aroclor-1232 } & 0.50 \\ 53469-21-9 & \text { Aroclor-1242 } & 0.50 \\ 12672-29-6 & \text { Aroclor-1248 } & 0.50 \\ 11097-69-1 & \text { Aroclor-1254 } & 1.0 \\ 11096-82-5 & \text { Aroclor-1260 } & 1.0 \\ 319-85-7 & \text { beta-BHC } & 0.05 \\ 319-86-8 & \text { delta-BHC } & 0.05 \\ 60-57-1 & \text { Dieldrin } & 0.10 \\ 959-98-8 & \text { Endosulfan I } & 0.05 \\ 33213-65-9 & \text { Endosulfan II } & 0.10 \\ 1031-07-8 & \text { Endosulfan Sulfate } & 0.10 \\ 72-20-8 & \text { Endrin } & 0.10 \\ 7421-93-4 & \text { Endrin Aldehyde } & 0.10 \\ 53494-70-5 & \text { Endrin Ketone } & 0.10 \\ 58-89-9 & \text { gamma-BHC (Lindane) } & 0.05 \\ 5103-74-2 & \text { gamma-Chlordane } & 0.50 \\ 76-44-8 & \text { Heptachlor } & 0.05 \\ 1024-57-3 & \text { Heptachlor Epoxide } & 0.05 \\ 72-43-5 & \text { Methoxychlor } & 0.50 \\ 8001-35-2 & \text { Toxaphene } & 1.0\end{array}$

Semivolatile Organics

$\begin{array}{lll}120-82-1 & \text { 1,2,4-Trichlorobenzene } & 11 \\ 95-50-1 & \text { 1,2-Dichlorobenzene } & 11 \\ 541-73-1 & \text { 1,3-Dichlorobenzene } & 11 \\ 106-46-7 & \text { 1,4-Dichlorobenzene } & 11 \\ 108-60-1 & \text { 2,2-0xybis(1-Chloropropane) } & 11 \\ 95-95-4 & \text { 2,4,5-Trichlorophenol } & 28 \\ 88-06-2 & \text { 2,4,6-Trichlorophenol } & 11\end{array}$

\footnotetext{
aCAS = Chemical Abstracts Service.
} 
Table A-8 (continued). Target Compound List of Organic Constituents Included in Analysis of Groundwater Samples

CAS Numbera Constituent Reporting Limit ( $\mu \mathrm{g} / \mathrm{L})$

\section{Semivolatile Organics (continued)}

\begin{tabular}{|c|c|}
\hline $\begin{array}{l}120-83-2 \\
105-67-9 \\
51-28-5 \\
121-14-2 \\
606-20-2 \\
91-58-7 \\
95-57-8 \\
91-57-6 \\
95-48-7 \\
88-74-4 \\
88-75-5 \\
91-94-1 \\
99-09-2 \\
534-52-1 \\
101-55-3 \\
59-50-7 \\
106-47-8 \\
7005-72-3 \\
106-44-5 \\
100-01-6 \\
100-02-7 \\
83-32-9 \\
208-96-8 \\
120-12-7 \\
56-55-3 \\
50-32-8 \\
205-99-2 \\
191-24-2 \\
207-08-9 \\
100-51-6 \\
111-91-1 \\
111-44-4 \\
117-81-7 \\
85-68-7 \\
86-74-8 \\
218-01-9 \\
84-74-2 \\
117-84-0\end{array}$ & 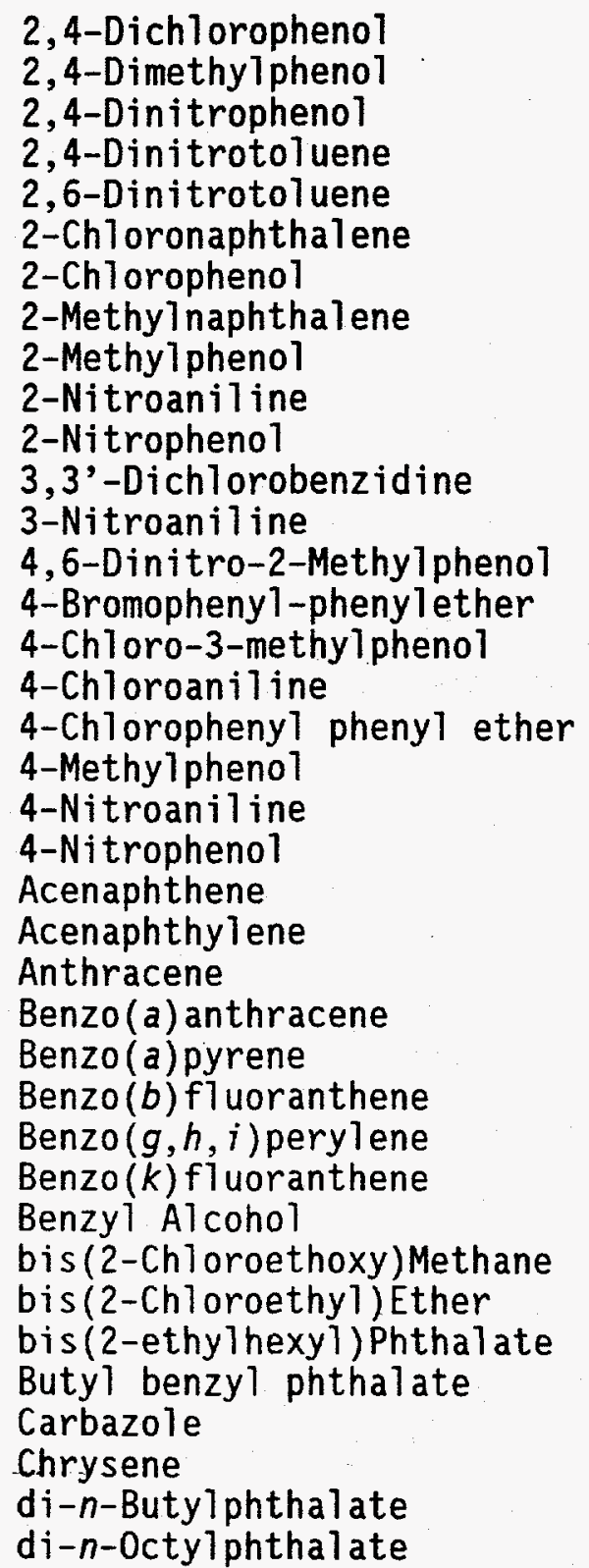 \\
\hline
\end{tabular}

aCAS = Chemical Abstracts Service. 
Table A-8 (continued). Target Compound List of Organic Constituents Included in Analysis of Groundwater Samples

CAS Numbera Constituent Reporting Limit $(\mu \mathrm{g} / \mathrm{L})$

$\begin{array}{lll}\text { Semivolatile } & \text { Organics (continued) } & \\ & & 11 \\ 53-70-3 & \text { Dibenz }(a, h) \text { anthracene } & 11 \\ 132-64-9 & \text { Dibenzofuran } & 11 \\ 84-66-2 & \text { Diethylphthalate } & 11 \\ 131-11-3 & \text { Dimethylphthalate } & 11 \\ 206-44-0 & \text { Fluoranthene } & 11 \\ 86-73-7 & \text { Fluorene } & 11 \\ 118-74-1 & \text { Hexachlorobenzene } & 11 \\ 87-68-3 & \text { Hexachlorobutadiene } & 11 \\ 77-47-4 & \text { Hexachlorocyclopentadiene } & 11 \\ 67-72-1 & \text { Hexachloroethane } & 11 \\ 193-39-5 & \text { Indeno(1,2,3-cd)pyrene } & 11 \\ 78-59-1 & \text { Isophorone } & 11 \\ 621-64-7 & \text { n-Nitroso-di-n-propylamine } & 11 \\ 86-30-6 & \text { n-Nitrosodiphenylamine } & 11 \\ 91-20-3 & \text { Naphthalene } & 28 \\ 98-95-3 & \text { Nitrobenzene } & 11 \\ 87-86-5 & \text { Pentachlorophenol } & 11 \\ 85-01-8 & \text { Phenanthrene } & 11 \\ 108-95-2 & \text { Phenol } & \\ 129-00-0 & \text { Pyrene } & \end{array}$

Volatile Organics

\begin{tabular}{|c|c|}
\hline $\begin{array}{l}71-55-6 \\
79-34-5 \\
79-00-5 \\
75-34-3 \\
75-35-4 \\
107-06-2 \\
540-59-0 \\
78-87-5 \\
78-93-3 \\
591-78-6 \\
108-10-1 \\
67-64-1 \\
71-43-2 \\
75-27-4 \\
75-25-2 \\
74-83-9\end{array}$ & $\begin{array}{l}\text { 1,1,1-Trichloroethane } \\
\text { 1,1,2,2-Tetrachloroethane } \\
\text { 1,1,2-Trichloroethane } \\
\text { 1,1-Dichloroethane } \\
\text { 1,1-Dichloroethene } \\
\text { 1,2-Dichloroethane } \\
\text { 1,2-Dichloroethene (total) } \\
\text { 1,2-Dichloropropane } \\
\text { 2-Butanone } \\
\text { 2-Hexanone } \\
\text { 4-Methyl-2-Pentanone } \\
\text { Acetone } \\
\text { Benzene } \\
\text { Bromodichloromethane } \\
\text { Bromoform } \\
\text { Bromomethane }\end{array}$ \\
\hline
\end{tabular}

aCAS $=$ Chemical Abstracts Service. 
Table A-8 (continued). Target Compound List of Organic Constituents Included in Analysis of Groundwater Samples

CAS Numbera Constituent Reporting Limit ( $\mu \mathrm{g} / \mathrm{L})$

\section{Volatile Organics (continued)}

$\begin{array}{llr}75-15-0 & \text { Carbon Disulfide } & 5 \\ 56-23-5 & \text { Carbon Tetrachloride } & 5 \\ 108-90-7 & \text { Chlorobenzene } & 5 \\ 75-00-3 & \text { Chloroethane } & 10 \\ 67-66-3 & \text { Chloroform } & 5 \\ 74-87-3 & \text { Chloromethane } & 10 \\ 156-59-2 & \text { cis-1,2-Dichloroethene } & 5 \\ 10061-01-5 & \text { cis-1,3-Dichloropropene } & 5 \\ 124-48-1 & \text { Dibromochloromethane } & 5 \\ 100-41-4 & \text { Ethyl benzene } & 5 \\ & \text { m,p-Xylene } & 5 \\ 75-09-2 & \text { Methylene Chloride } & 5 \\ 95-47-6 & \text { o-Xylene } & 5 \\ 100-42-5 & \text { Styrene } & 5 \\ 127-18-4 & \text { Tetrachloroethene } & 5 \\ 108-88-3 & \text { Toluene } & 5 \\ 156-60-5 & \text { trans-1,2-Dichloroethene } & 5 \\ 10061-02-6 & \text { trans-1,3-Dichloropropene } & 5 \\ 79-01-6 & \text { Trichloroethene } & 5 \\ 108-05-4 & \text { Vinyl Acetate } & 10 \\ 75-01-4 & \text { Vinyl Chloride } & 10 \\ 1330-20-7 & \text { Xylenes (total) } & 5 \\ & & \end{array}$

$$
\text { acAS = Chemical Abstracts Service. }
$$




\section{Appendix B Time-Concentration Graphs}




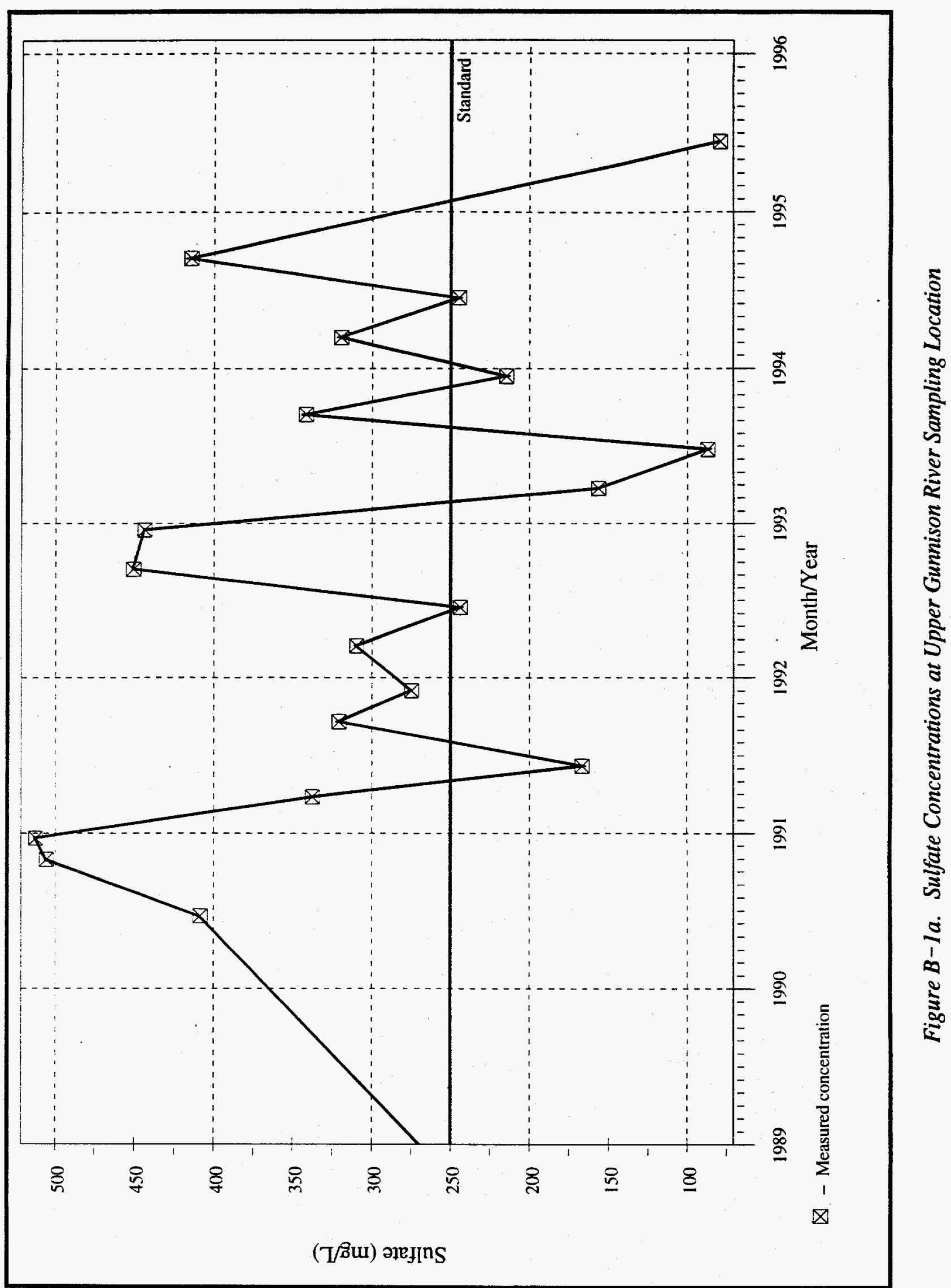




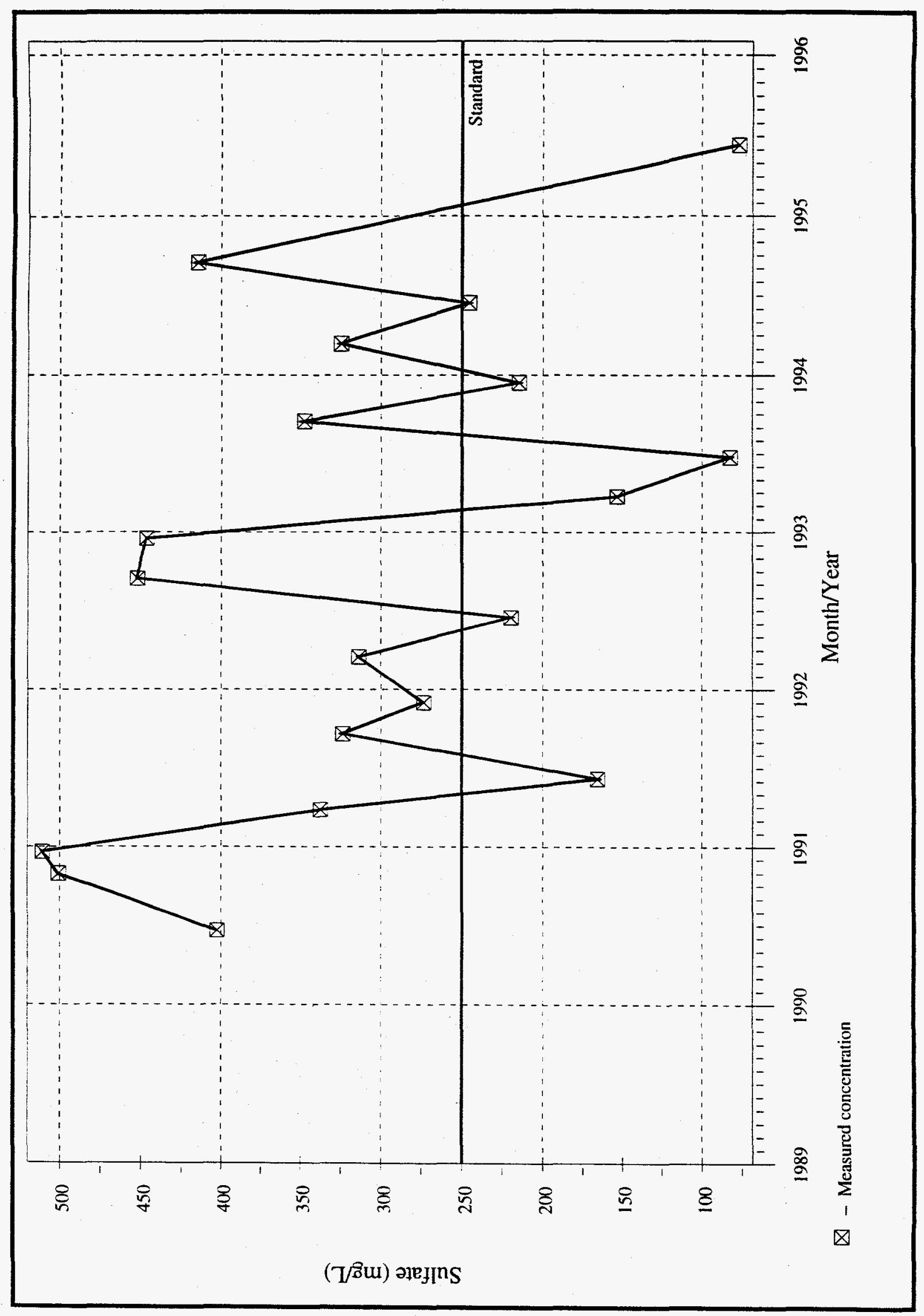

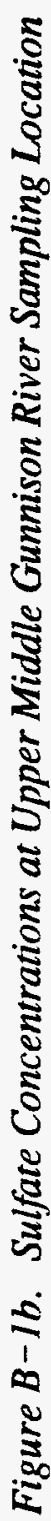




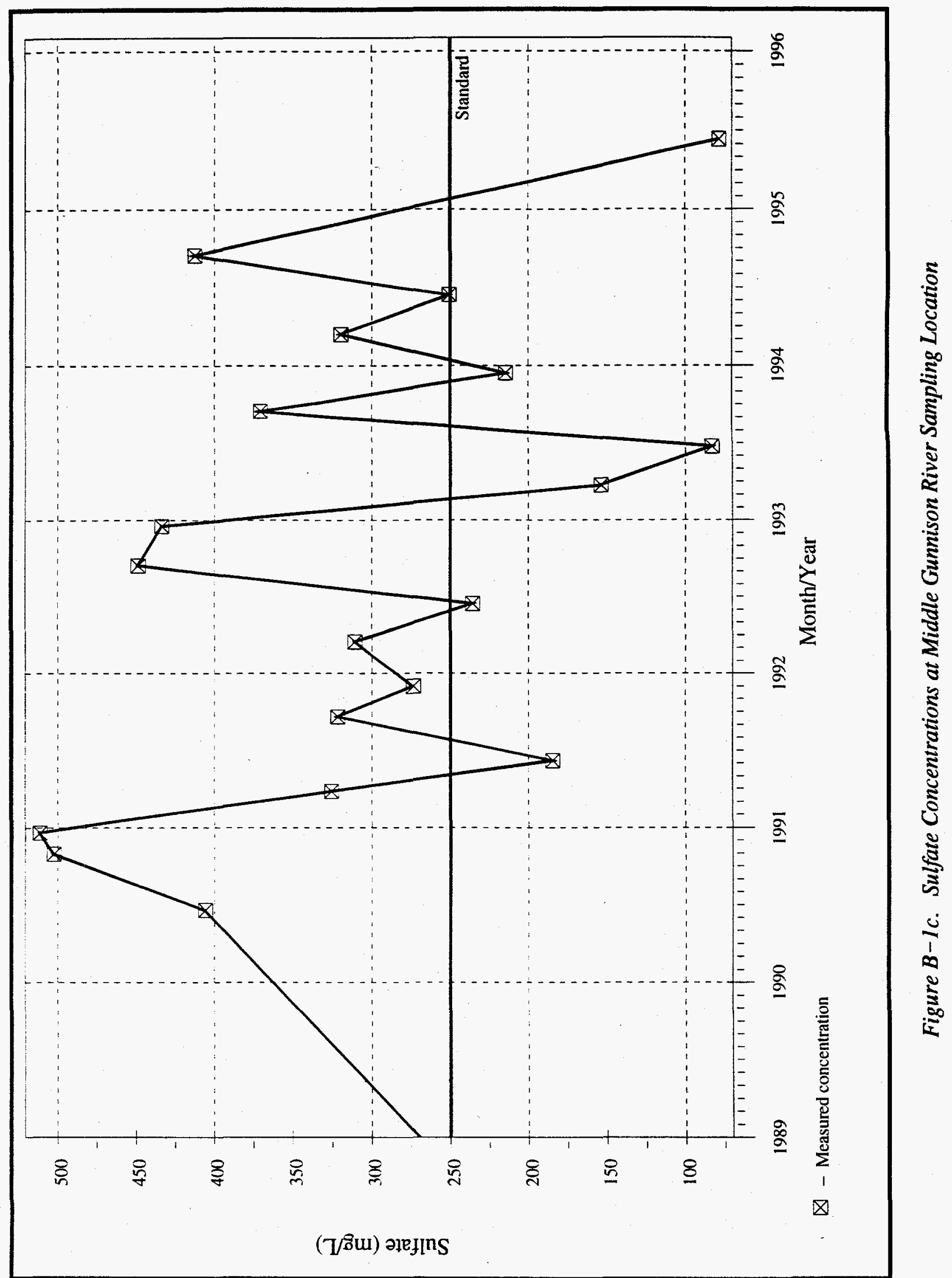




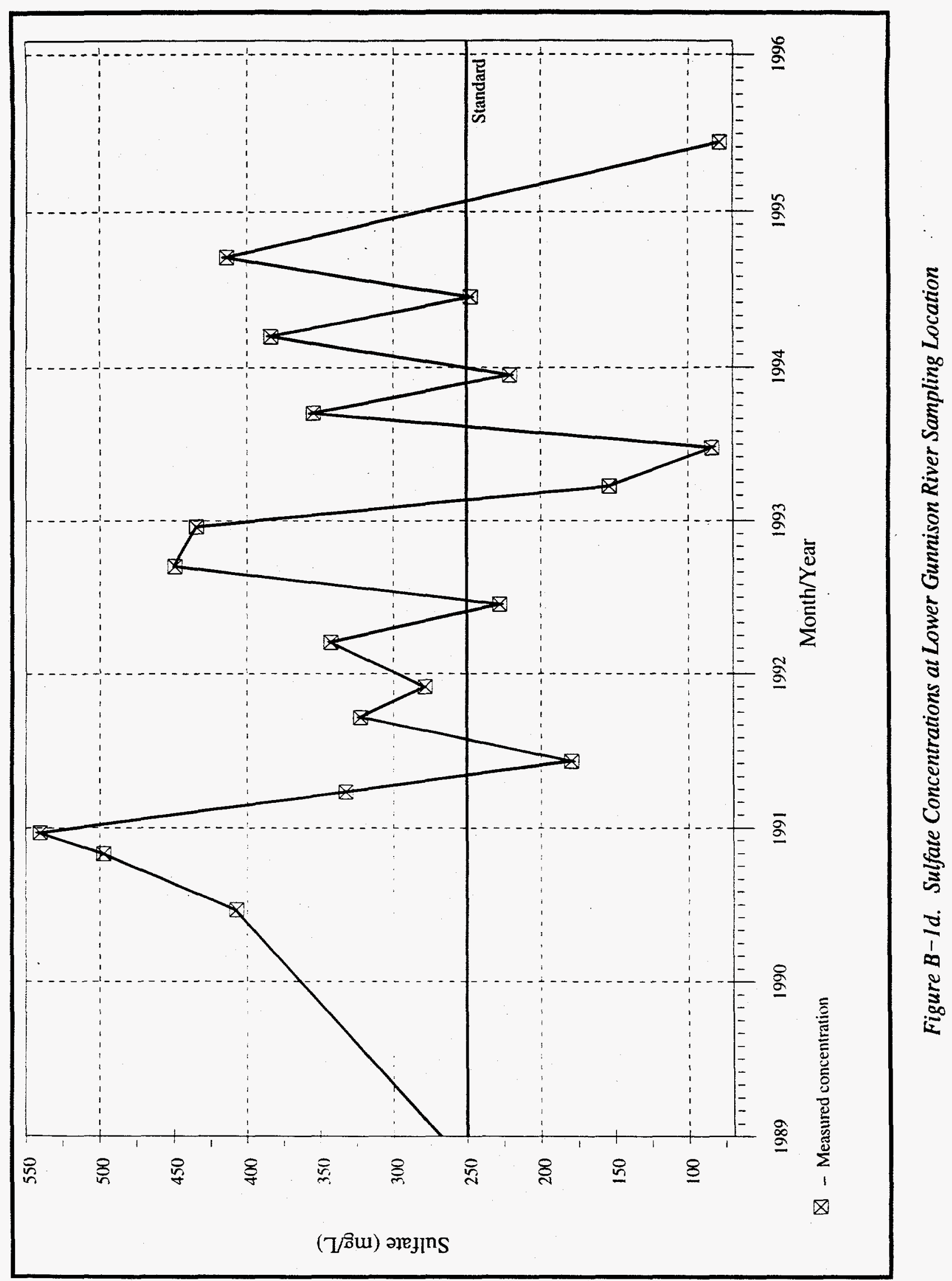




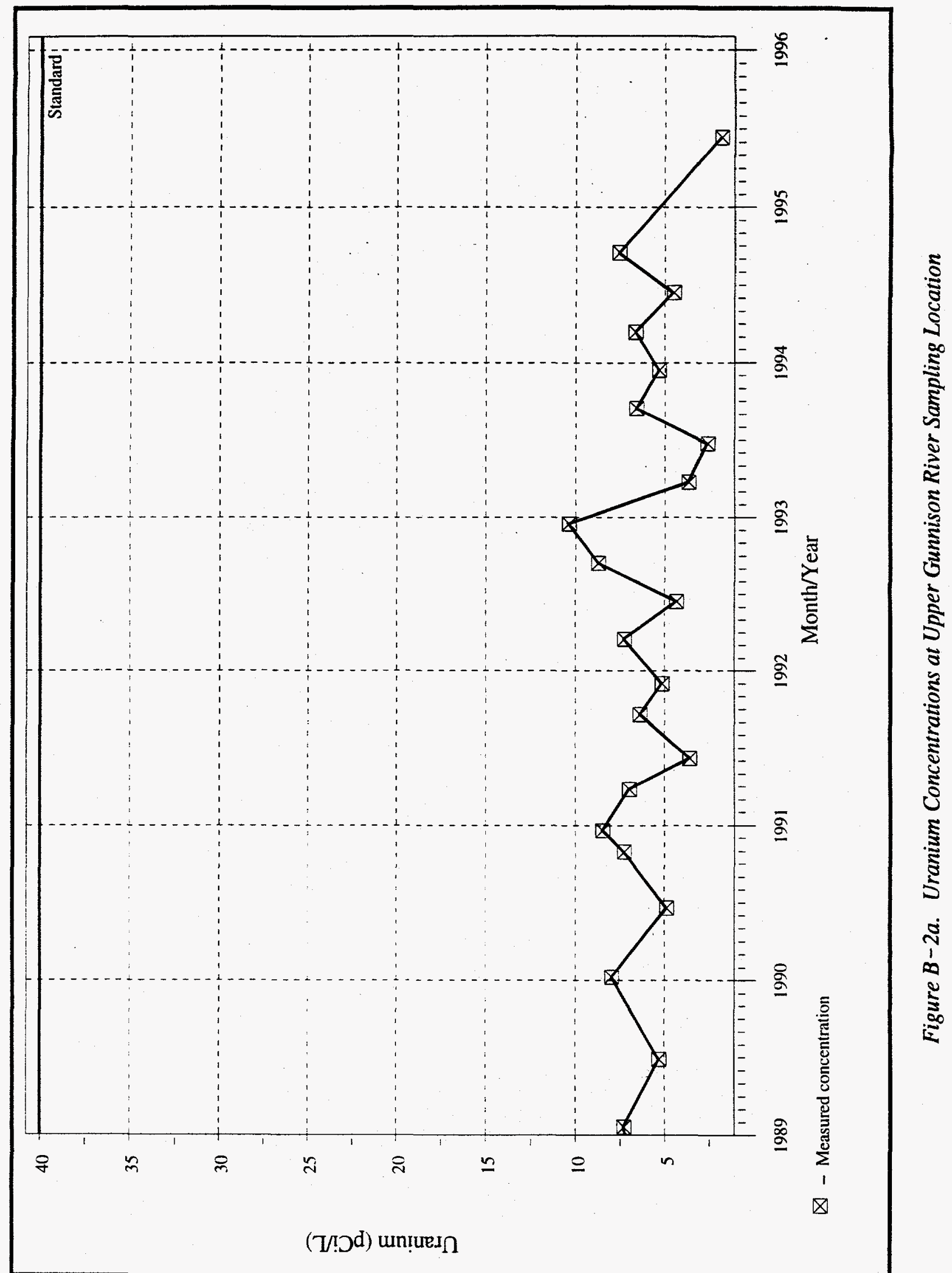




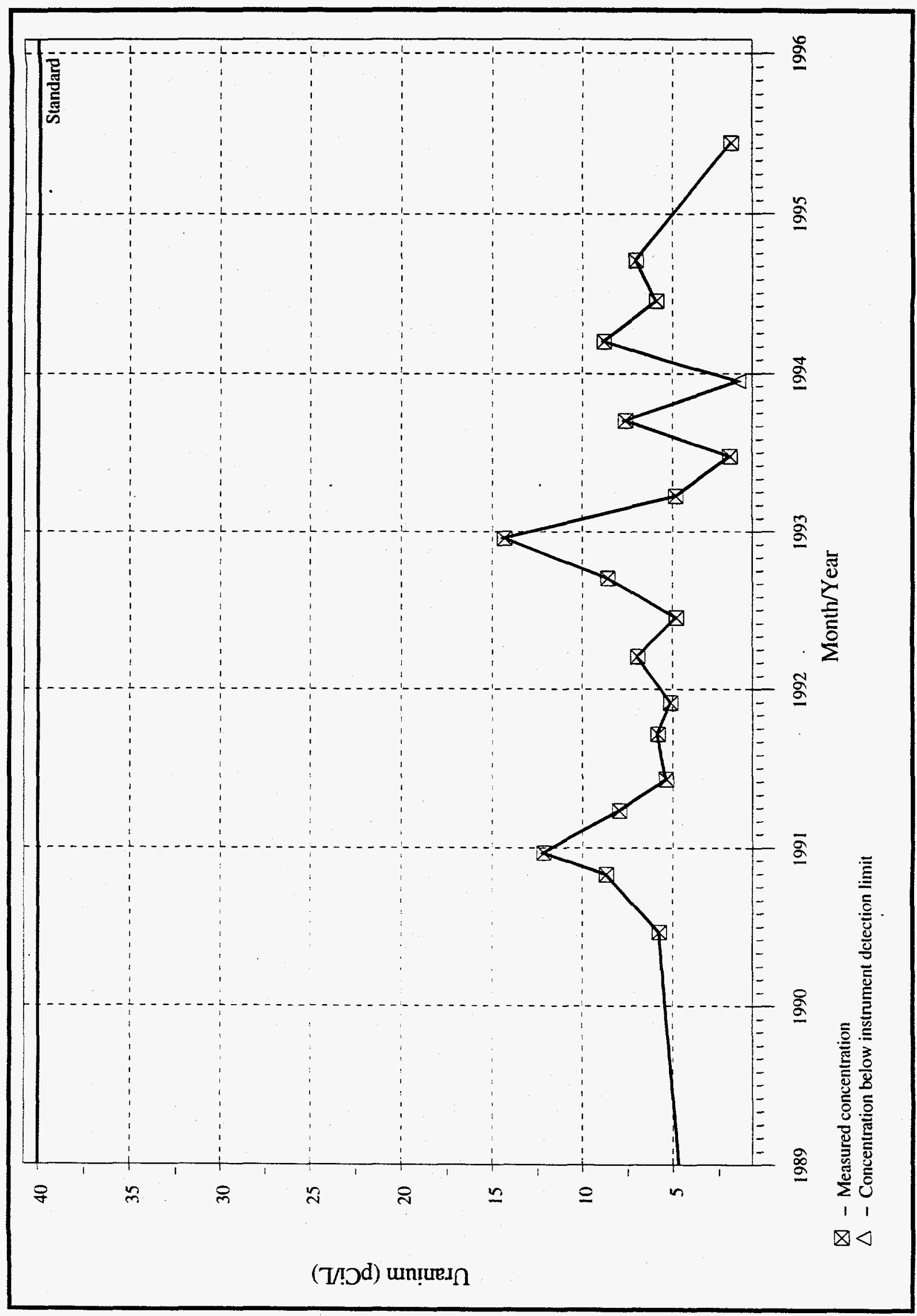

|⿹ 


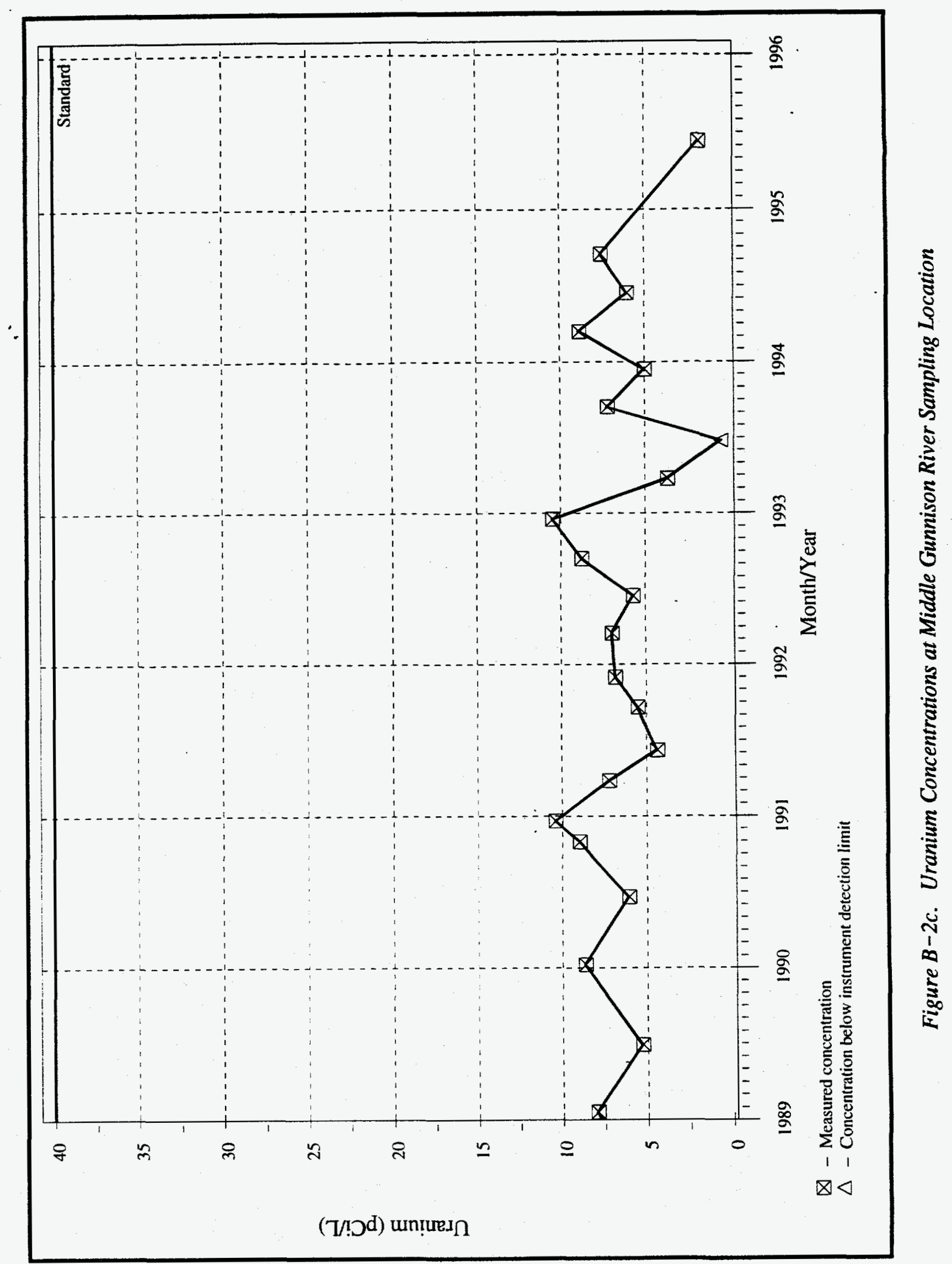




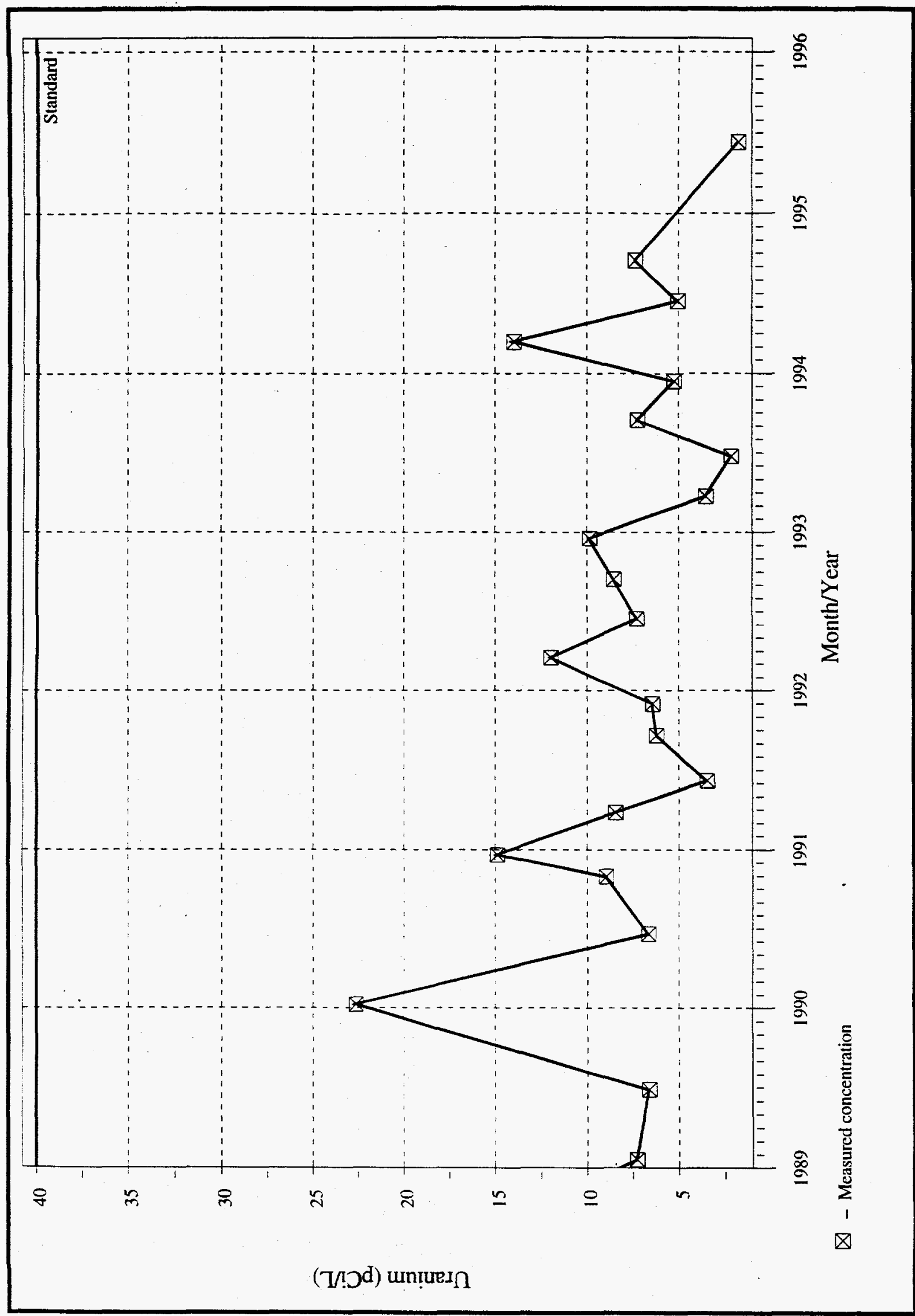

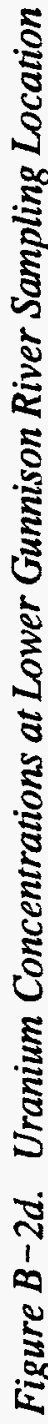




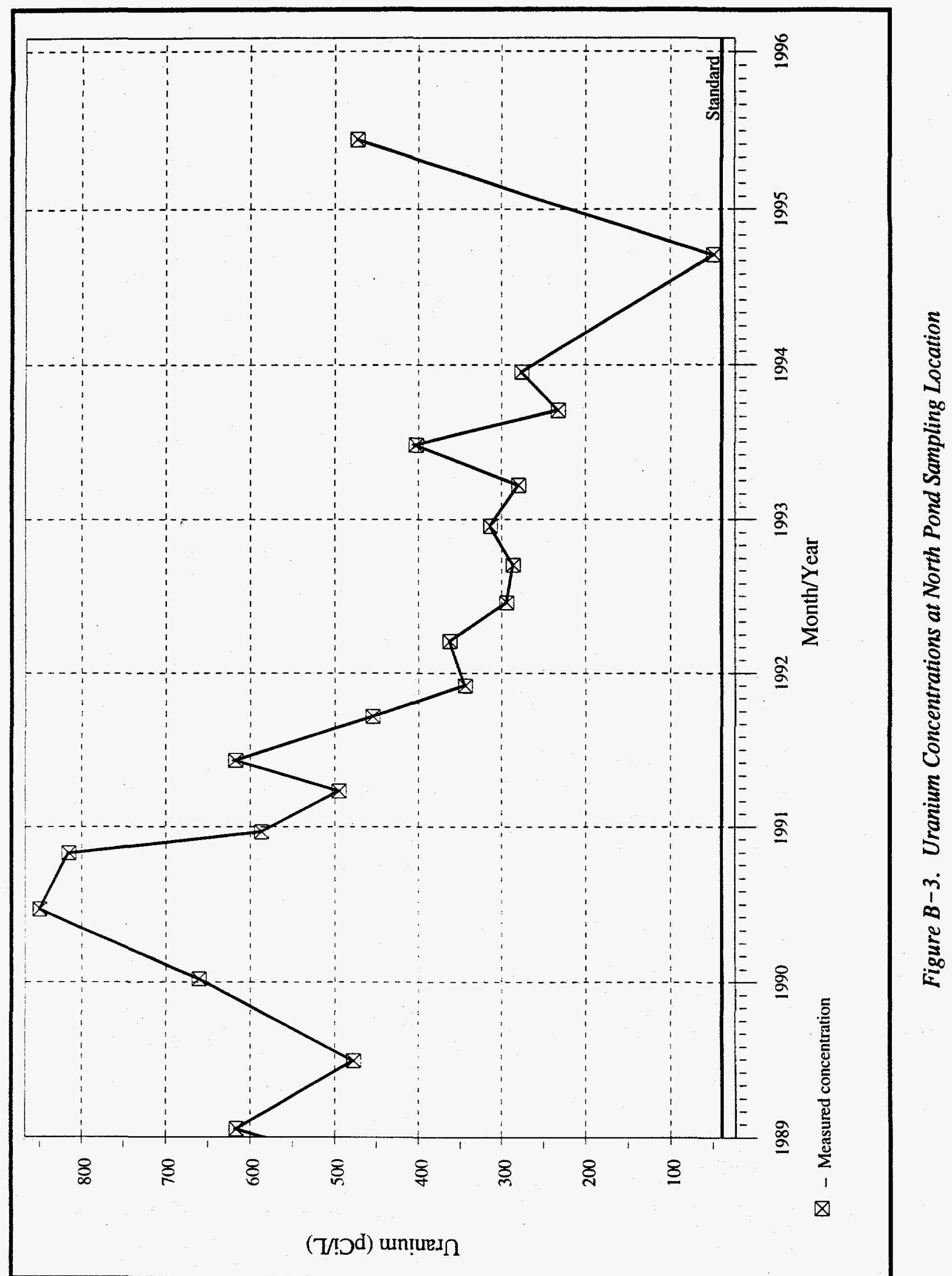




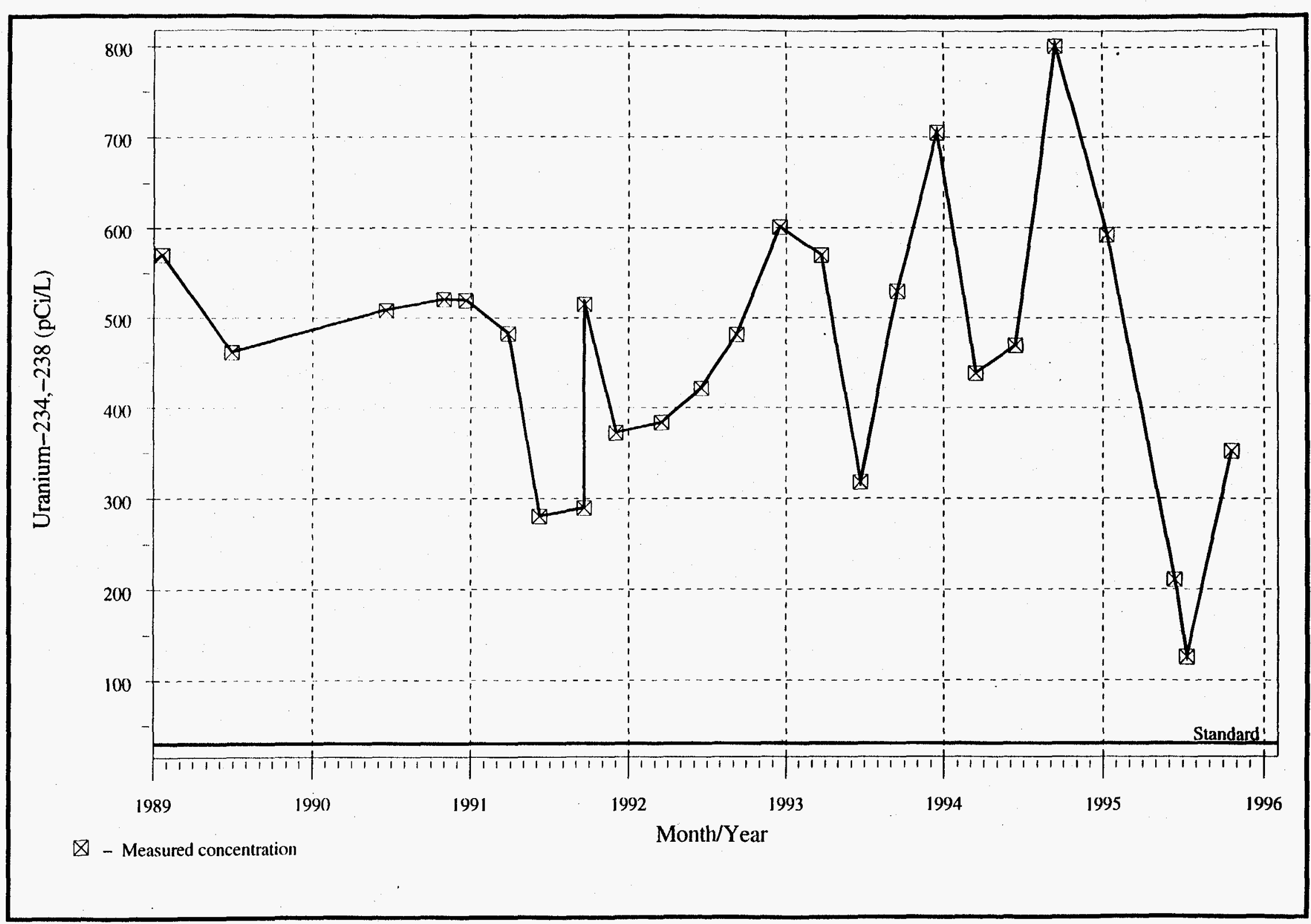

Figure B-4a. Uranium-234,-238 Concentrations in Downgradient Well GJ84-04 


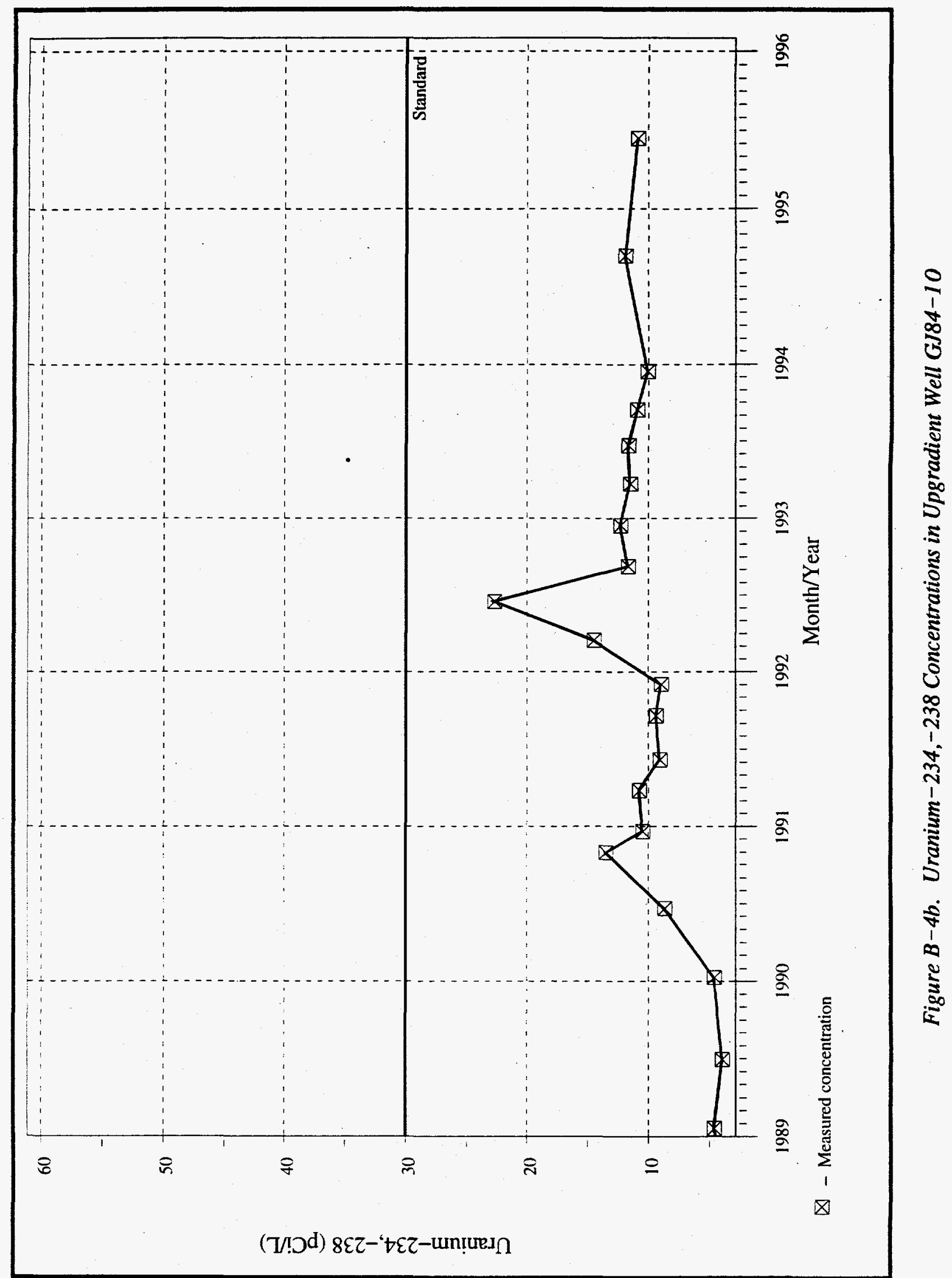




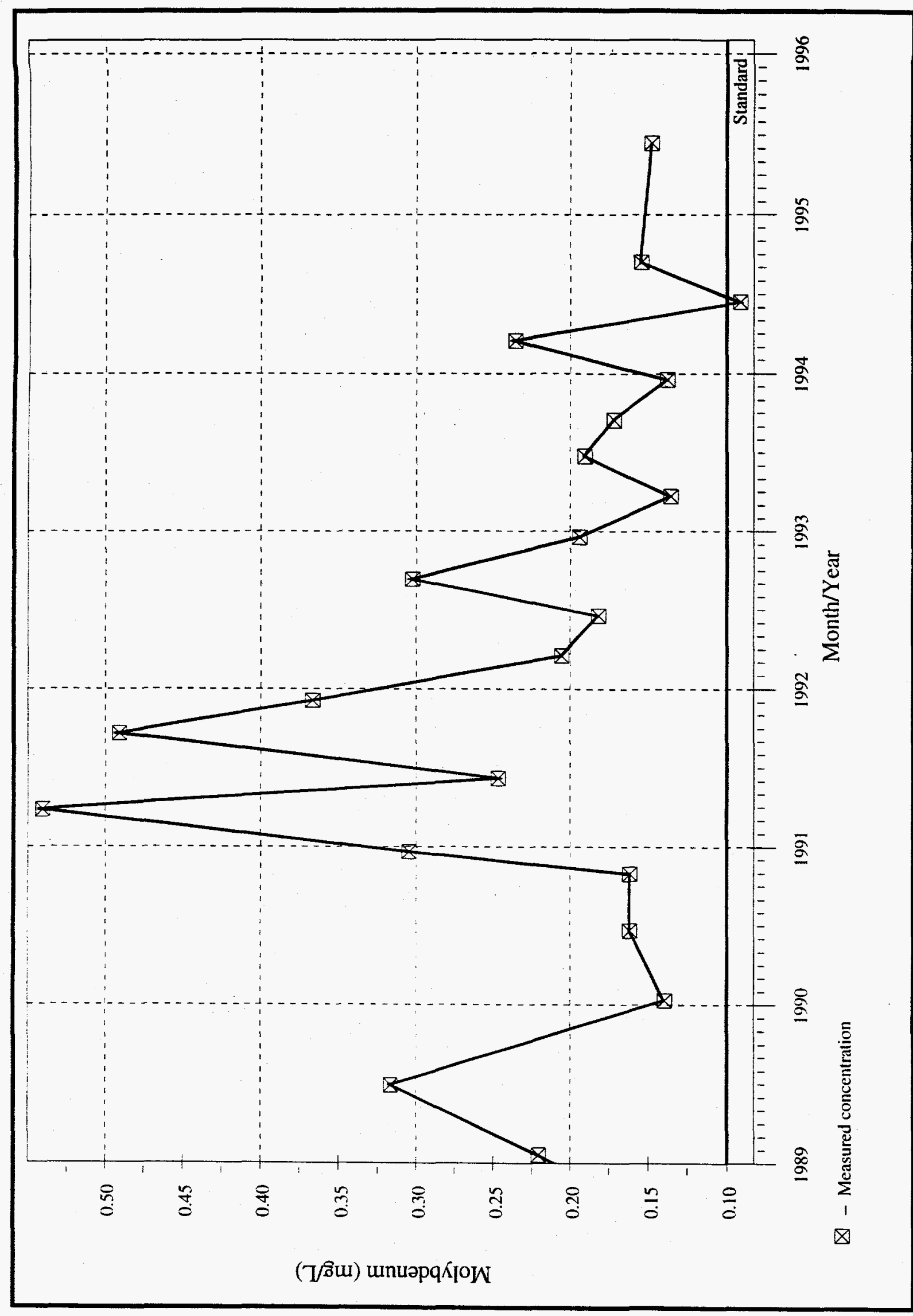




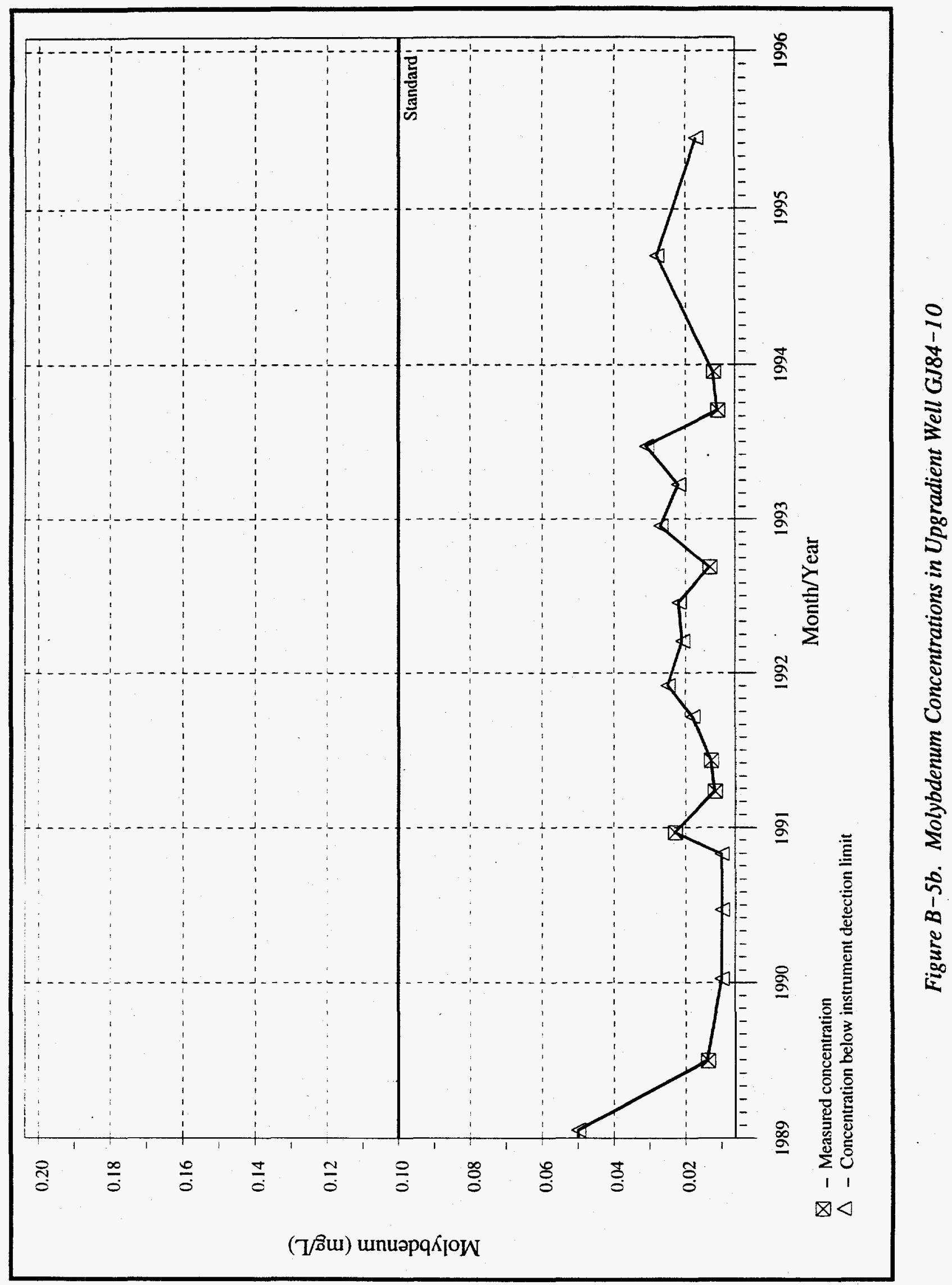




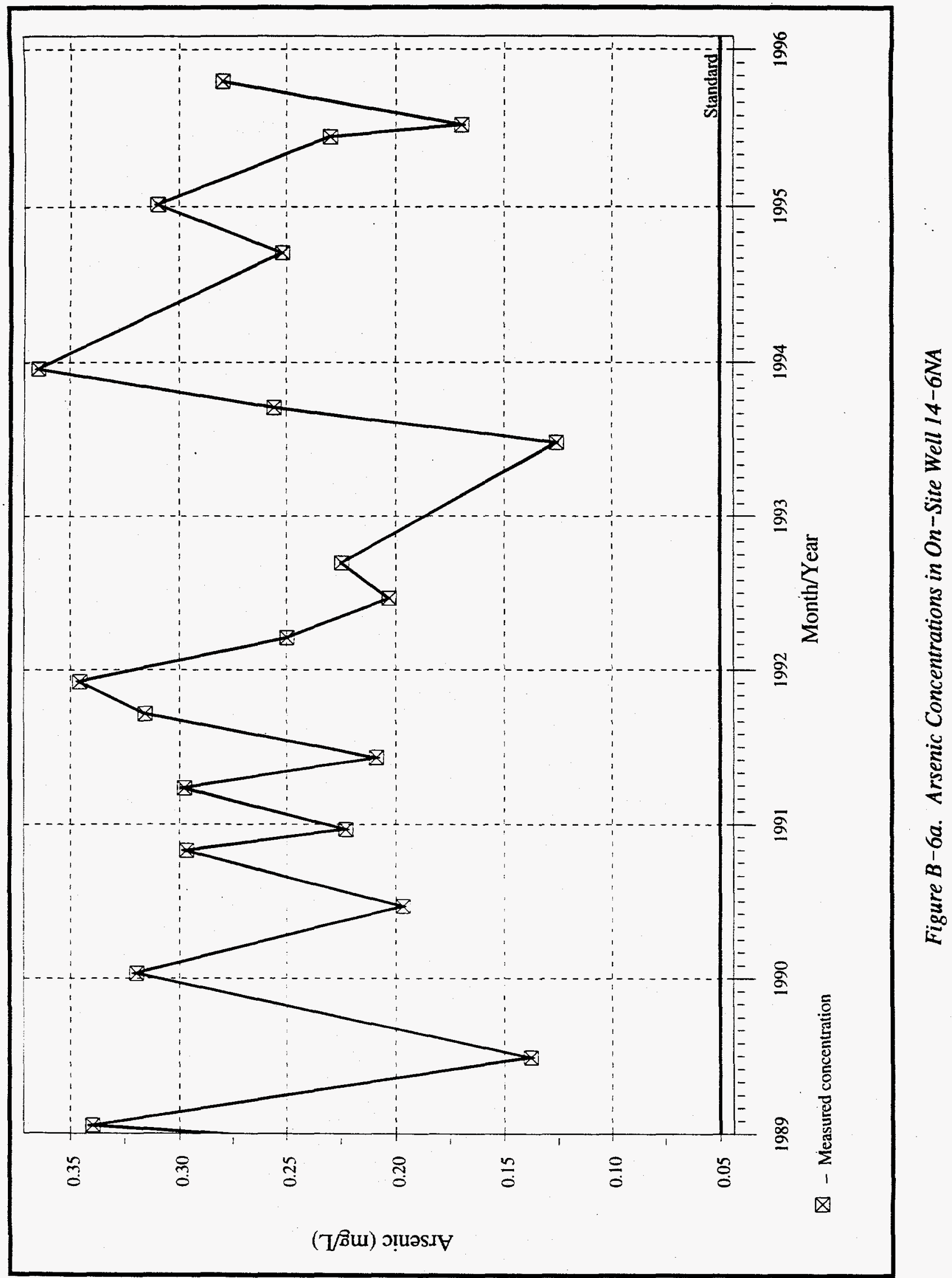




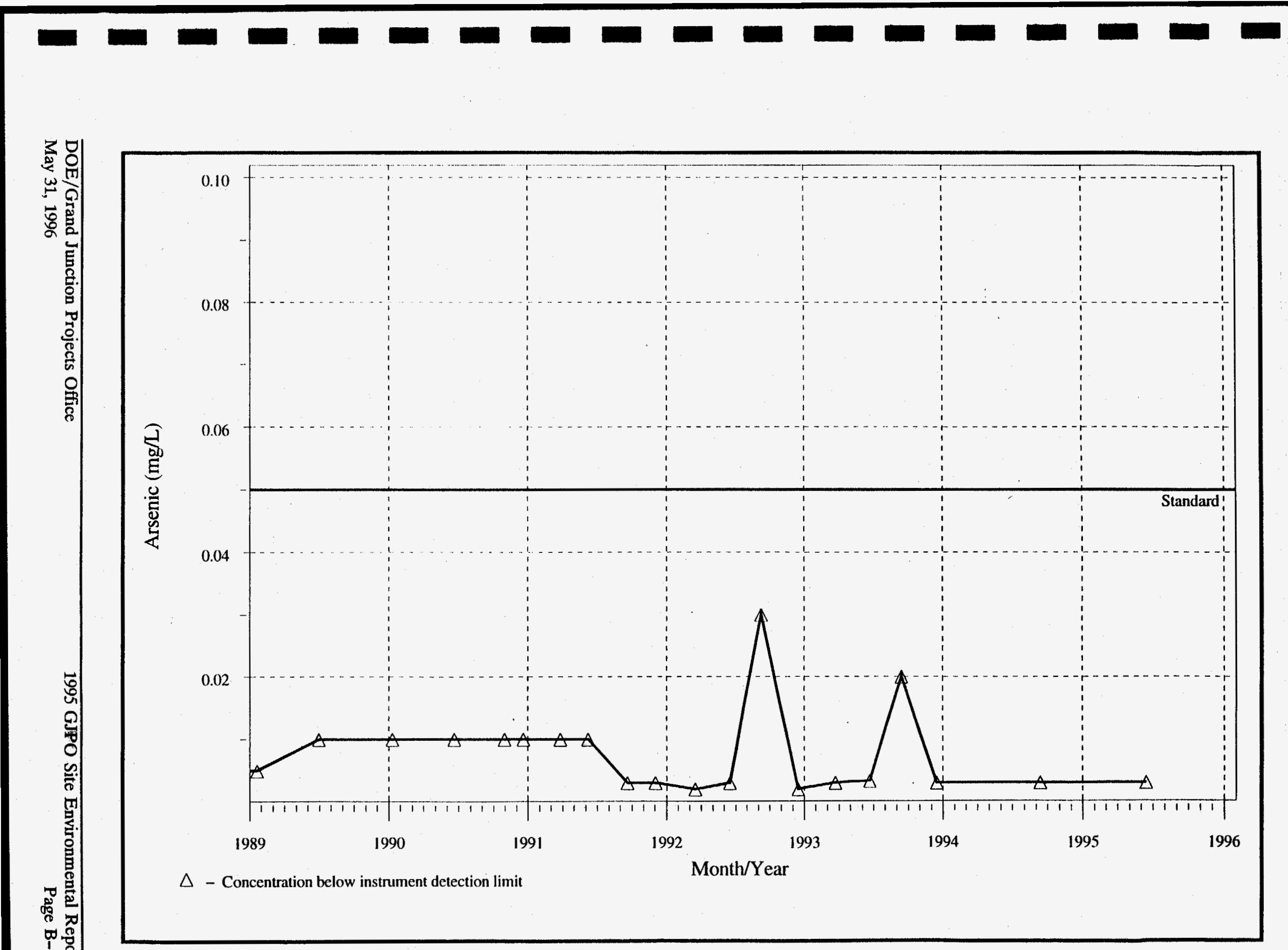

Figure B-6b. Arsenic Concentrations in Upgradient Well GJ84-10 


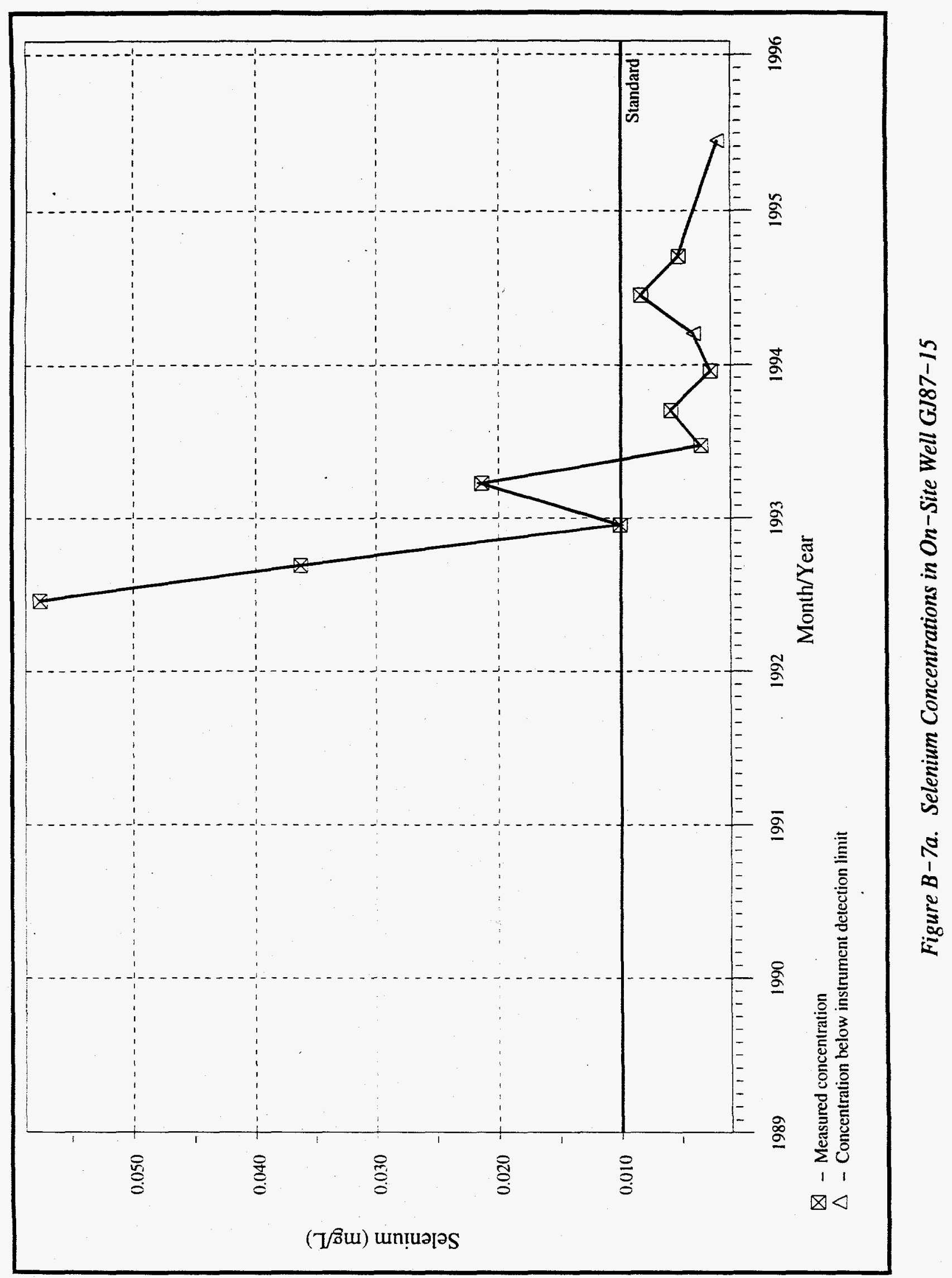




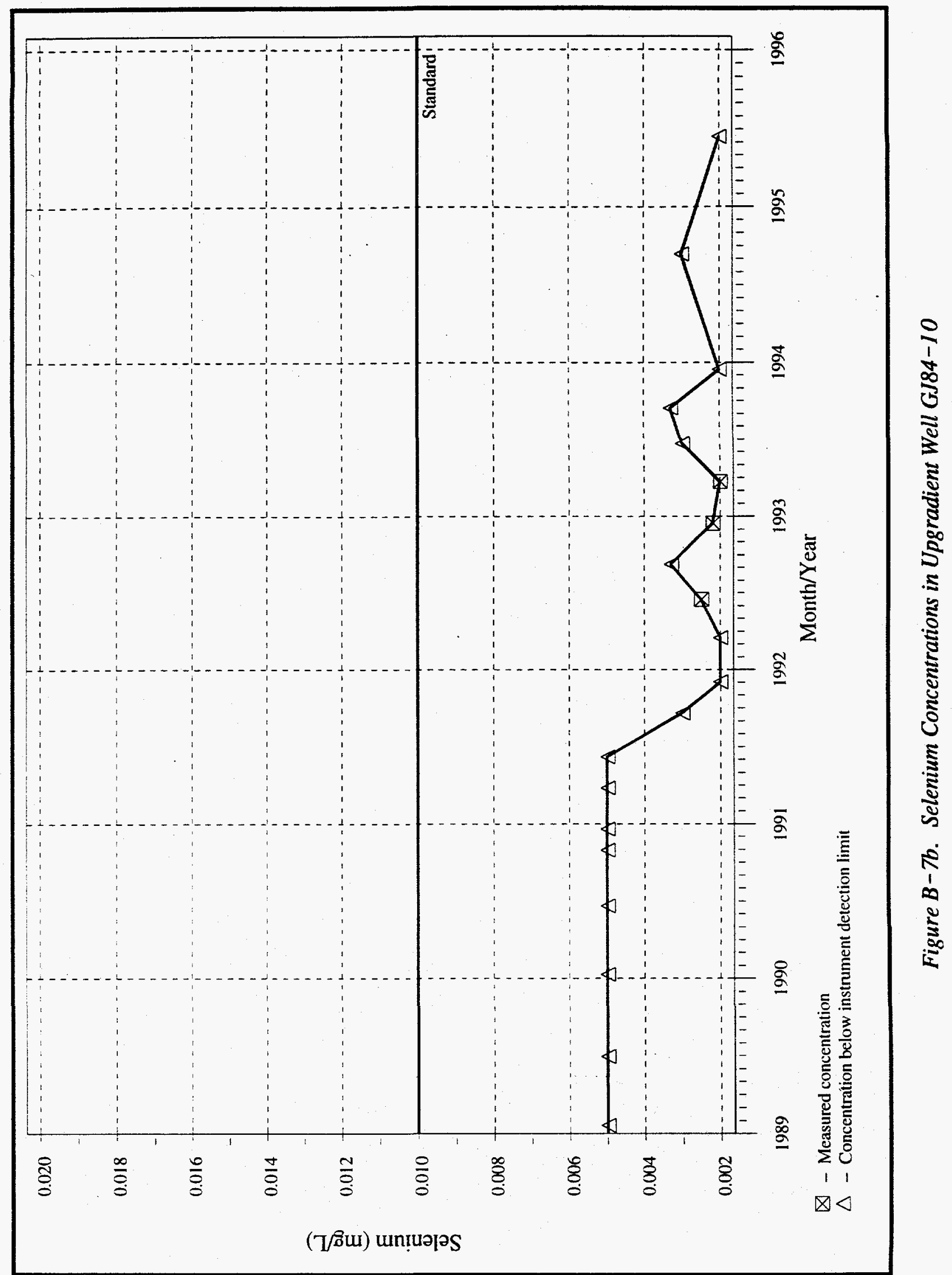




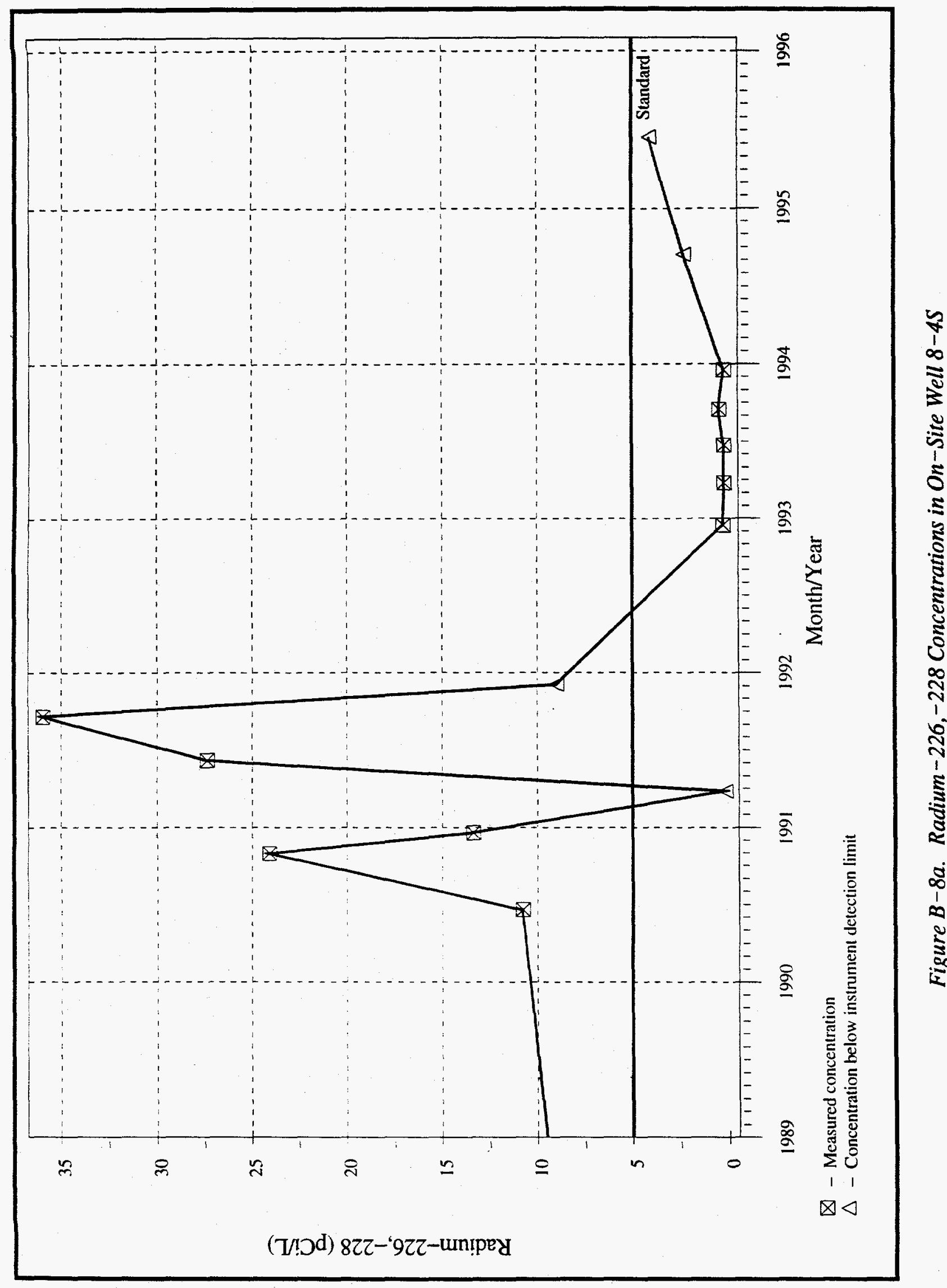




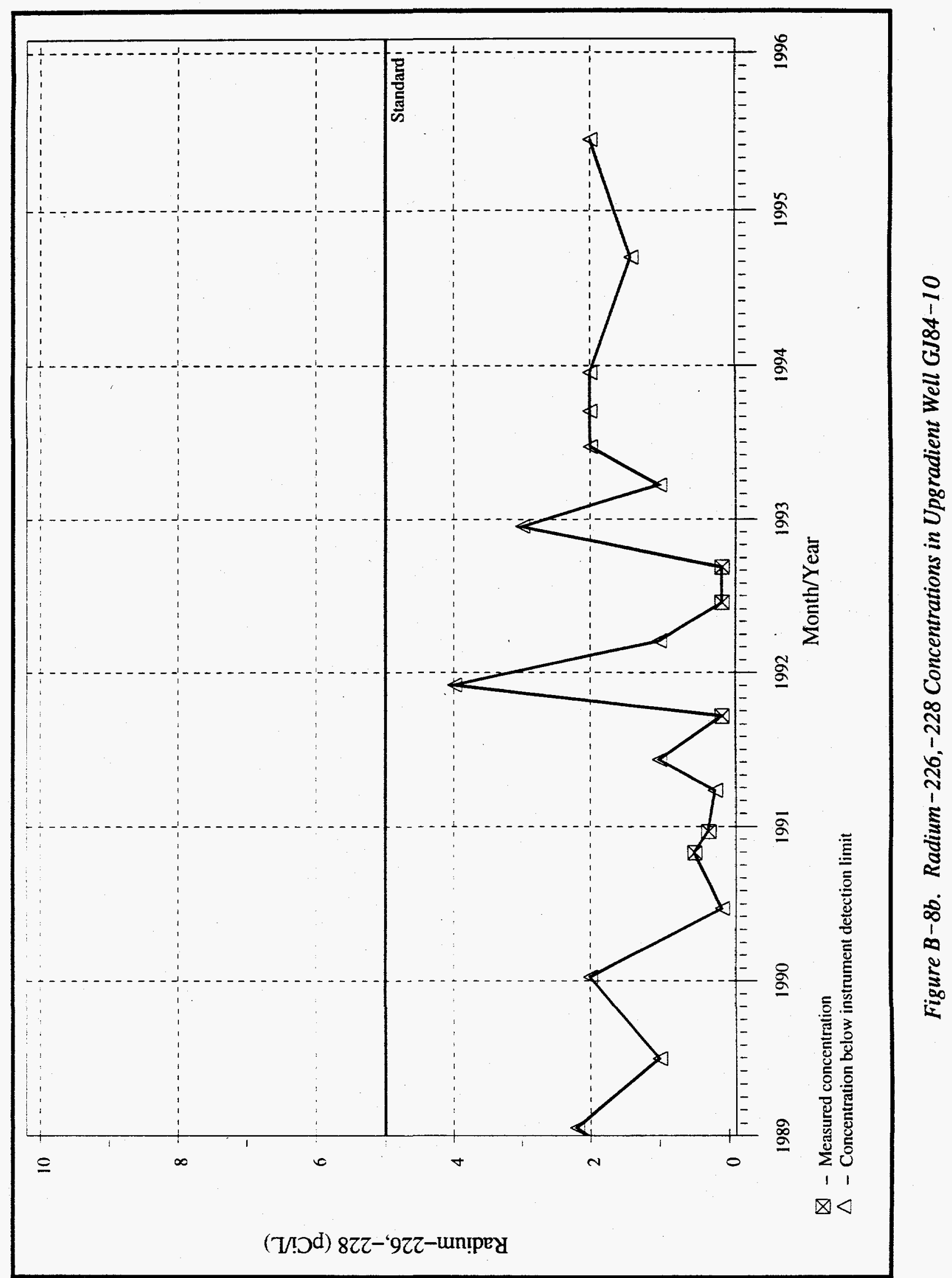




\section{Appendix C \\ Well Location Maps Showing Groundwater Analytes Exceeding Federal or State Standards}




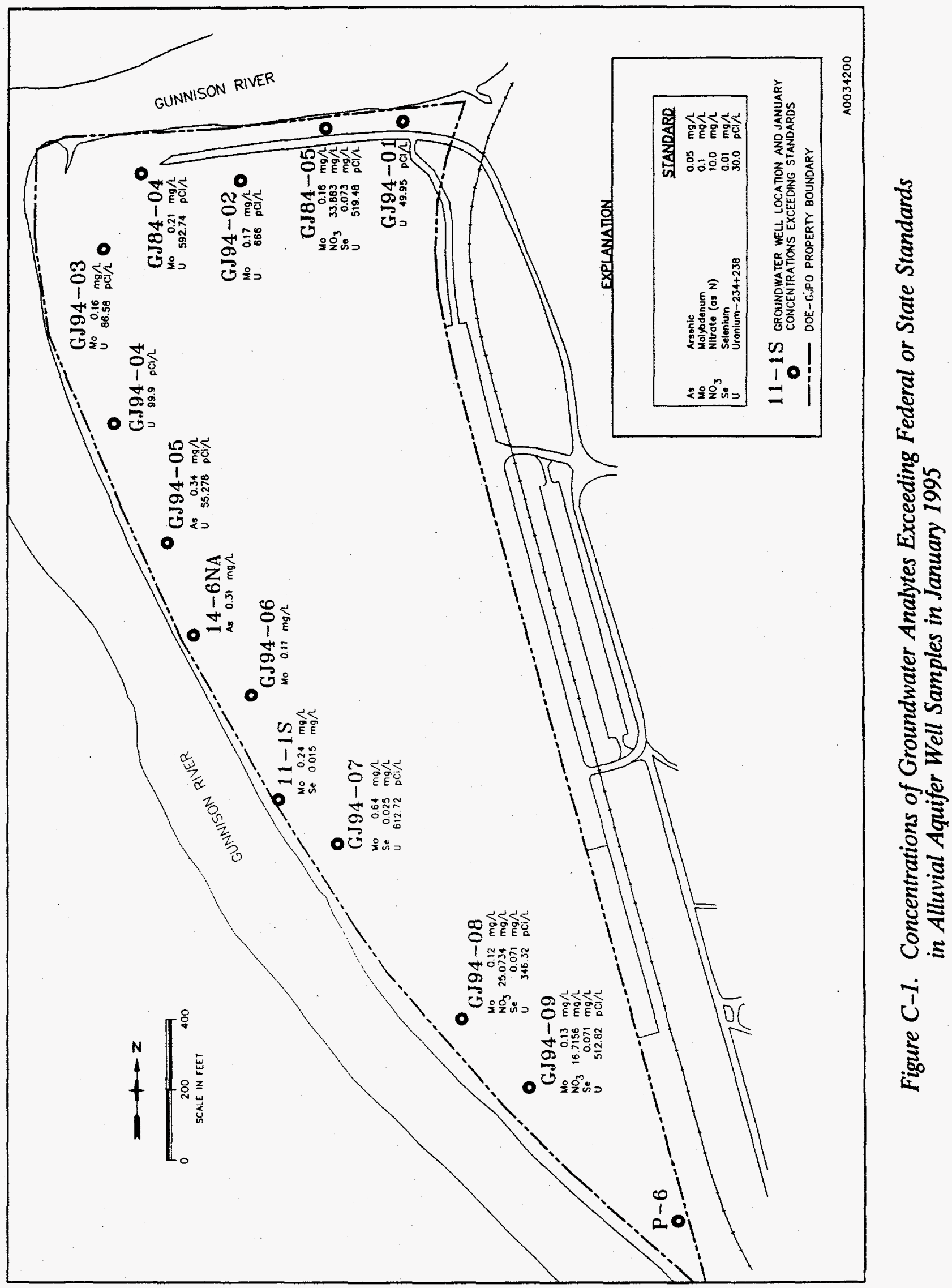



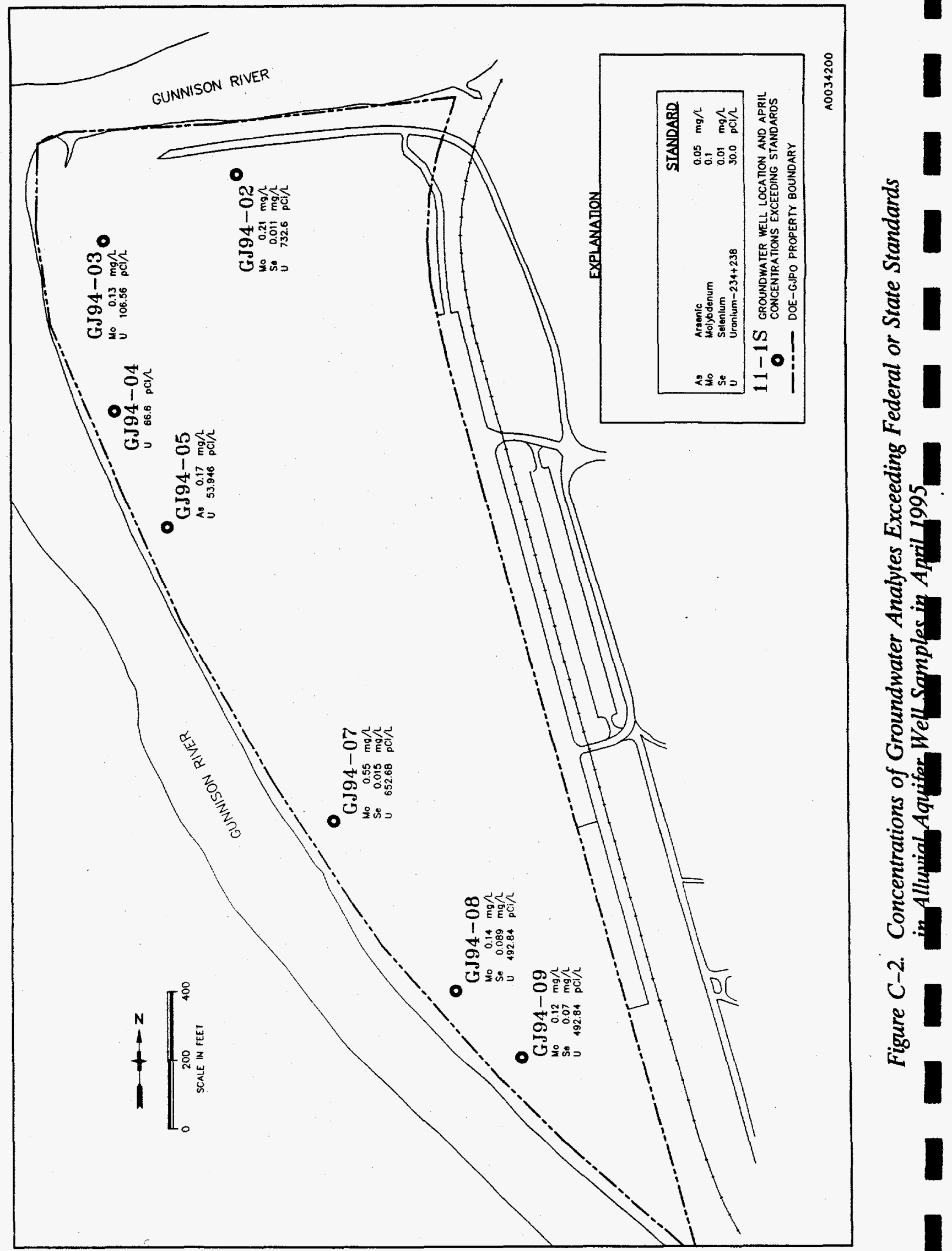

$\sum_{\substack{1 \\ 0}}^{j}$ 


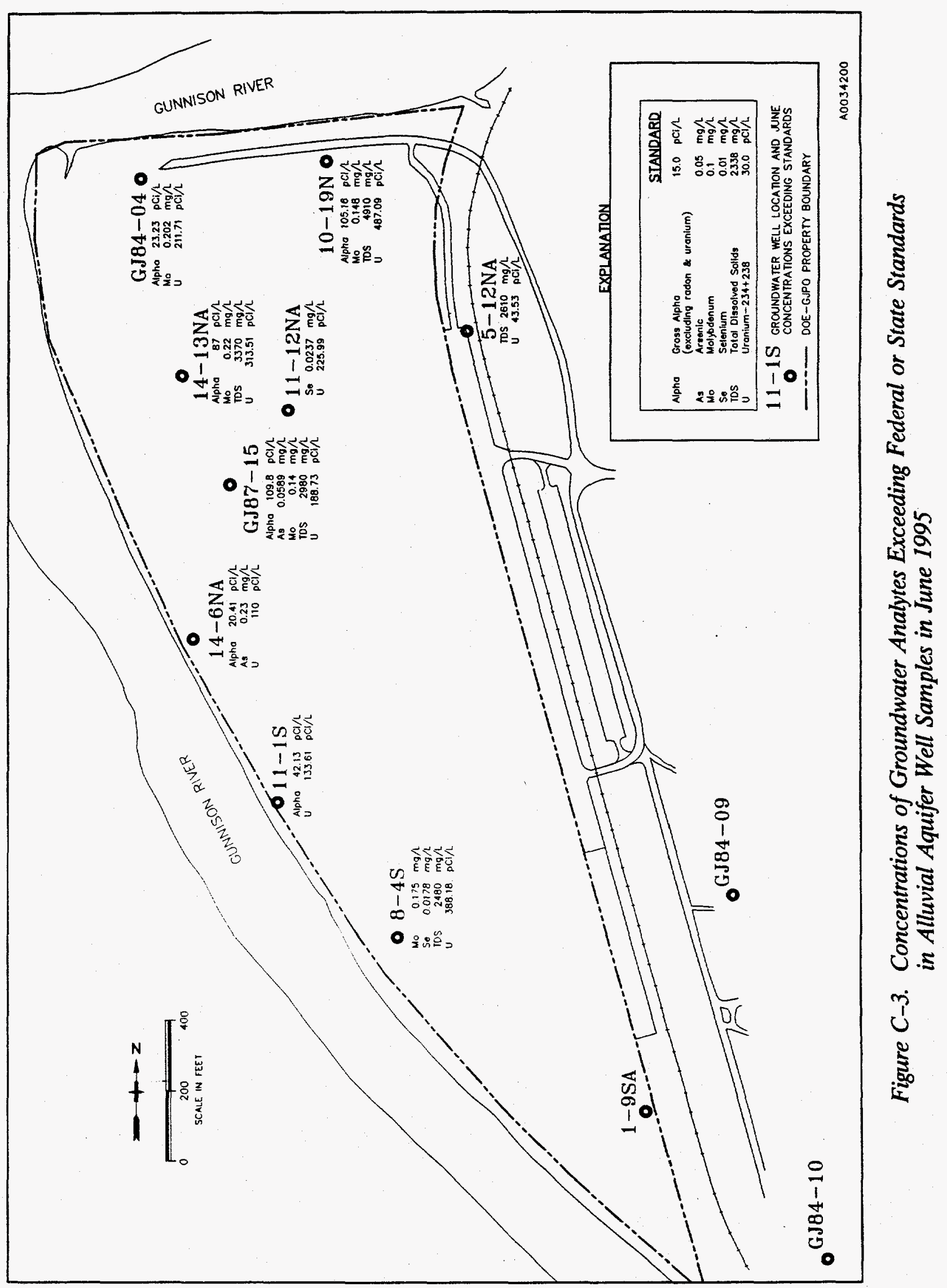




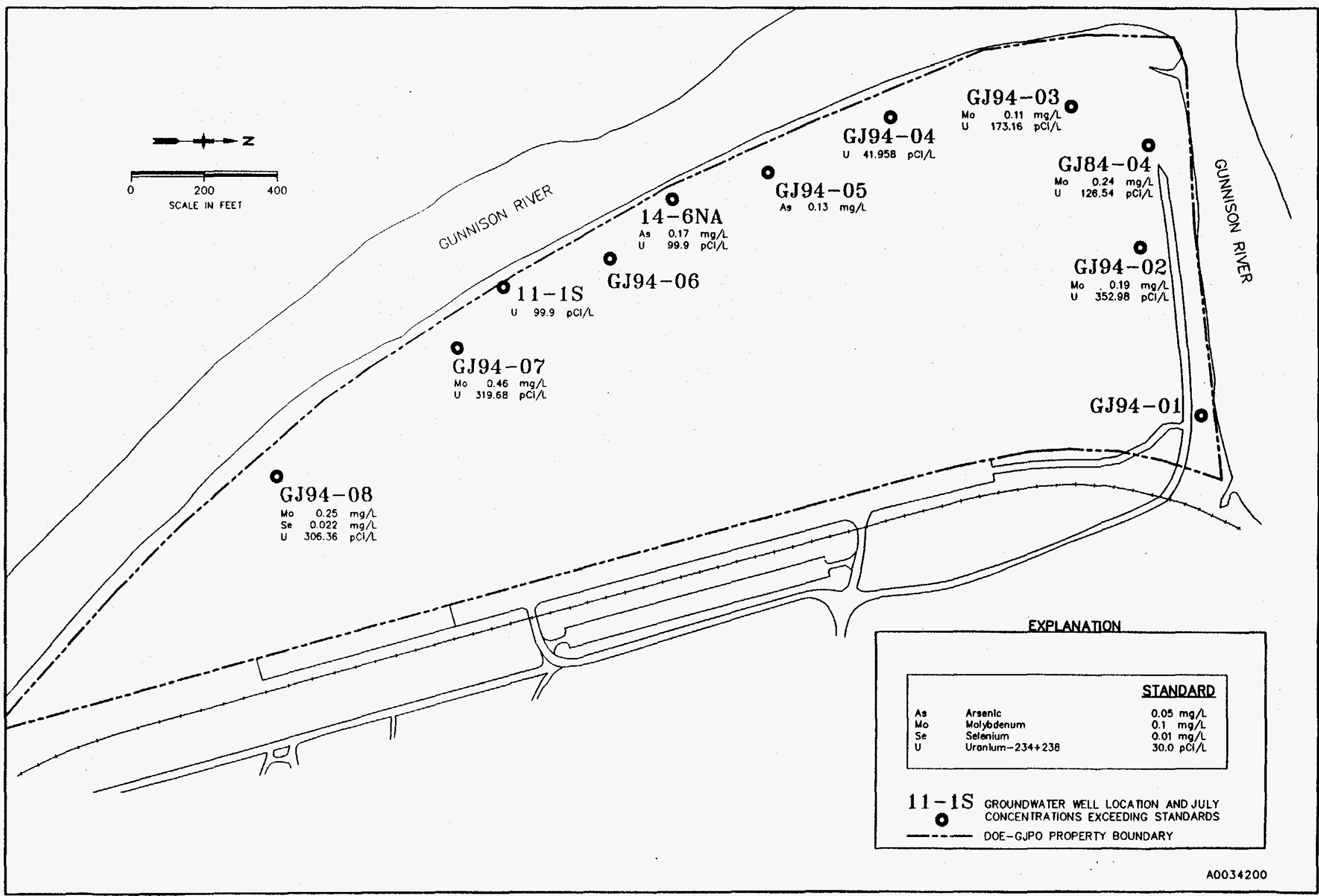

Figure C-4. Concentrations of Groundwater Analytes Exceeding Federal or State Standards 


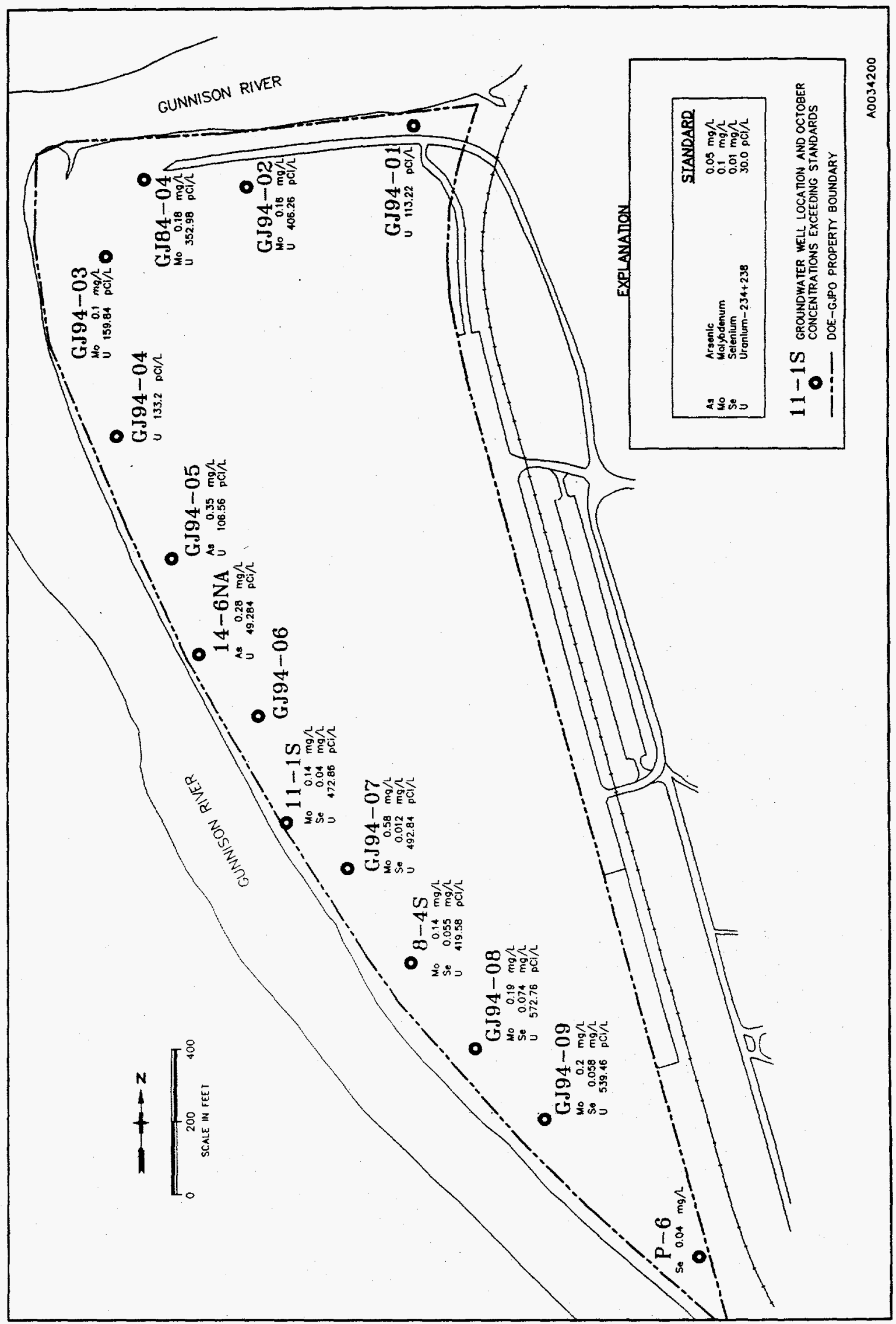

ปิ 